\title{
Taxonomic studies in Stipa (Poaceae) in Australia
}

\author{
J.W. Vickery†, S.W.L. Jacobs and J. Everett
}

\begin{abstract}
Vickery, J.W., Jacobs, S.W.L. and Everett, J. (National Herbarium of New South Wales, Royal Botanic Gardens, Sydney, Australia 2000) 1986. Taxonomic studies in Stipa (Poaceae) in Australia. Telopea 3(1): I-132. - In a revision of Stipa in Australia sixty-one native species with five subspecies, and five introduced species are recognized and described. Stipa nullarborensis, S. lanata, S. wakoolica, S. centralis, S. dongicola, S. feresetacea, S. velutina, S. aquarii, S. pilata, S. blakei and S. echinata are described as new with a new combination made for $S$, scabra subsp. falcata.
\end{abstract}

\section{Introduction}

Bentham (1878) made the first attempt to revise the Australian species of Stipa, treating some 15 species. Hughes (1921) revised the Australian species from specimens held at Kew, increasing the number of species to 40 . The following year she published the results of her examination of material held in the U.S. National Herbarium, clarifying some nomenclatural problems and describing two further species.

Since 1922 most studies have been on a regional basis or occasional taxa published in isolation, the best example of these being Townrow's (1978) recent study of Tasmanian Stipa. As a result of these and other publications, and the introduction of some species from other countries, the number of Australian species described had risen to 50 before the commencement of the present study by the late Dr Joyce Vickery. Vickery (1980) published four species, and Everett and Jacobs (1983) three species to date as part of this study. This treatment describes a further 11 species and reduces two others to subspecies, recognizing 66 species and five subspecies.

Although we are satisfied that the Australian species are congeneric with Stipa, there are, as yet, no adequate studies examining the relationships within Stipa on a worldwide basis. One of us (JE) is undertaking such a study, but progress to date is insufficent for any comments on relationships.

\section{Organisation of the Text}

The species are arranged alphabetically. The systematic relationships of the Australian species and their affinities with non-Australian species still require further study. Our present thoughts on the relationships of the Australian species are presented in the 'natural' Key 1, which suffers from being a one-dimensional presentation. Although the composition of the groups is useful information, the arrangement within the groups and the arrangement of the groups is not necessarily significant. At present we include some species in two groups. 
Key 2 is in a tabular format and is more or less equivalent to a 'multiple-access' key.

The descriptions are mostly organized conventionally and where there are two or more alternative states (e.g. glabrous or hairy) the more common state is mentioned first.

An index to the major place of mention of extant names, synonyms, uncertain and excluded taxa follows the descriptions.

The list of specimens cited represents only a selection of specimens examined, especially for the more widespread species. A further list is available from the Library, Royal Botanic Gardens, Sydney, 2000. Even this additional list, however, does not include all the specimens examined. Standard abbreviations are used for the herbaria with the addition of ACB (Herbarium of A.C. Beauglehole), JEST (Herbarium of J.E.S. Townrow) and Corrick herb. (Herbarium of M.J. Corrick).

\section{Evaluation of Characters}

Life cycle: all Australian species of Stipa are facultative perennials. Minute plants producing one spikelet can be found during extremely dry seasons.

Rootstock and shoots: most species are caespitose, but some are wiry and scrambling in habit; others have thickened culms, produce numerous branches at the nodes and are reminiscent of small bamboos. In Australia there are rhizomatous species but no truly stoloniferous species.

New culms may be either intravaginal or extravaginal. The distinction is not always consistent within a species, but the general appearance it gives to the base can be a useful character.

Culm: the culms are basically circular in cross-section. The internodes are hollow. The nodes are frequently swollen and often coloured differently from the internodes. The number of nodes is a useful character in a few cases.

Leaves: the sheaths, blades and ligules of the leaves are variable within the one plant depending on whether the leaf is an innovation-leaf or a culm-leaf, and if a culm-leaf then on its position relative to the inflorescence. Unless otherwise stated all descriptions of these characters are based on the second culm-leaf below the inflorescence, i.e. the leaf directly below the flag.

Sheaths: the sheaths are open and glabrous, scabrous or hairy. Long-hairy sheaths can be a distinguishing character. In some species the sheaths become loose with age. The top of the sheath can merge with the ligule forming a complex structure consisting of both ligule and sheath lobes ( $\equiv$ auricles?). Although there is some doubt as to when these lobes can be regarded as auricles, we have used the latter term throughout.

Ligule: the ligule and auricles are useful characters. The combined structure is frequently asymmetric. The auricles may be thickened or have a thickened base with membranous margins and, when present, the membranous margins are often continuous with the ligule. The ligule is membranous but may be reduced to a thickened ridge.

Blades: the blades may be flat, rolled or folded. Most species have linear leaves but some species have leaves that are only about 5 times as long as broad, although the shape is influenced greatly by environmental factors. S. stipoides, 
$S$. echinata and $S$. pilata have pungent-pointed leaves. Some species have more or less rigid leaves but most leaves are more or less lax.

Townrow (1978) emphasized the adaxial leaf surface ornamentation ('ALSO' sensu Townrow) as a diagnostic character in her work on Tasmanian species of Stipa. This approach appears to be worth developing but requires refining to make it useful on an Australia-wide basis. In particular it will be important to distinguish the macrohairs and siliceous outgrowths, which are known to vary with habitat, from the significant epidermal features. In Tasmania this distinction would possibly be of little consequence but it is significant when the whole area of Australia is considered. The ornamentation characters seem also to have been partly responsible for some differences between our taxonomic conclusions and those of Townrow.

We have not yet critically examined leaf anatomy or epidermal features for the genus. Such a study would be useful for examining the subgeneric relationships within Australia and the relationships of Australian Stipa to those in the rest of the world.

Inflorescence: the inflorescence is basically a panicle, in the sense of being open and much branched. Some species, e.g. $S$. muelleri, have inflorescences reduced to 1 or few spikelets whereas others, e.g. S. verticillata, have large, muchbranched inflorescences. Most species fall between these two extremes but the extreme inflorescence types are useful diagnostic characters, as to a lesser extent is the size of the inflorescence.

The inflorescences appear to be terminal but it is not uncommon to find a second inflorescence produced from either the first or second node immediately below the terminal inflorescence. This inflorescence is produced intravaginally and in most cases is not easy to distinguish from the terminal inflorescence. The occurrence of a 'second inflorescence' appears to be more common during periods of stress and does not appear to be of much value as a taxonomic character.

Spikelets: the spikelets are 1-flowered and in none of the specimens we examined was there any evidence of a rhachilla extension. (One specimen of S. bigeniculata (NSW 117419) has 2-flowered spikelets.) The spikelets can appear laterally flattened due to the often-keeled glumes, even though the floret is virtually cylindrical.

Glumes: the glumes are unequal or subequal. The number of nerves varies from 1 to 7 and, within certain limits, can be useful as a diagnostic character. Glume length is a very useful key character. The glume tips are important in affecting the general appearance of the spikelets. In some species the glume tips are quite membranous and easily torn; when examining such species, care is necessary to ensure that undamaged glumes are examined for both appearance and measurements.

The mid-nerve extends from the base to the tip. The lateral nerves usually occur in pairs, with one of each pair on either side of the midrib. The lateral nerves continue for varying distances along the glume from the base and this distance can be a distinguishing character. We have expressed this as the percentage of the glume length with a particular number of nerves, e.g. 'the lower 50\% 5-nerved, the next 25\% 3-nerved', means that the two outermost nerves extend halfway, the next pair extending to three quarters the length of the glume, the midvein continuing to the tip. 


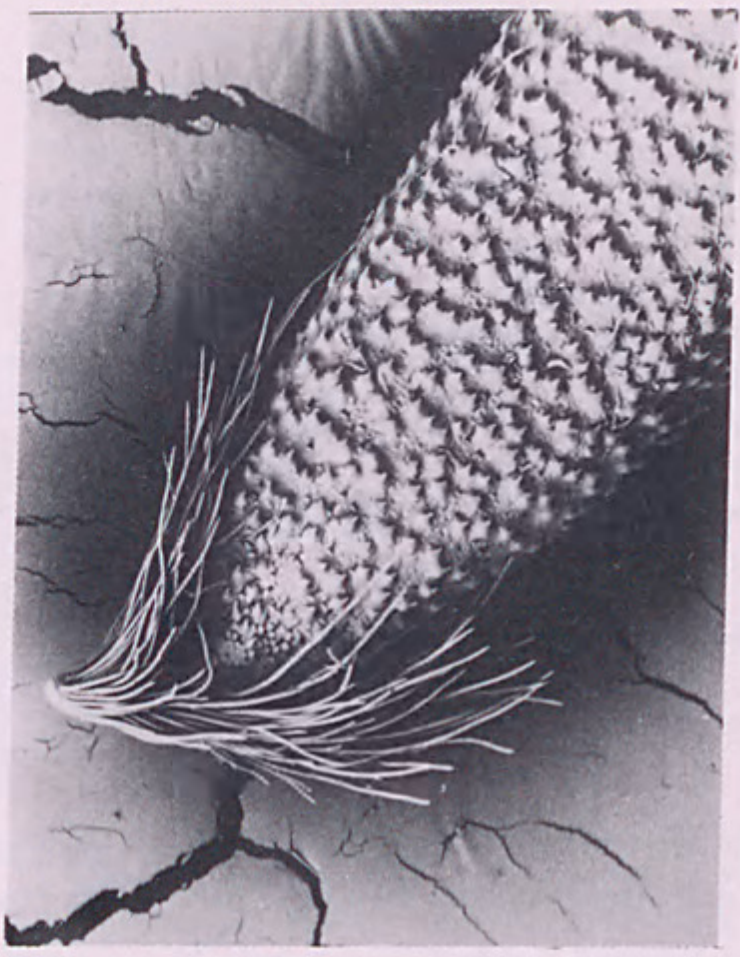

a.

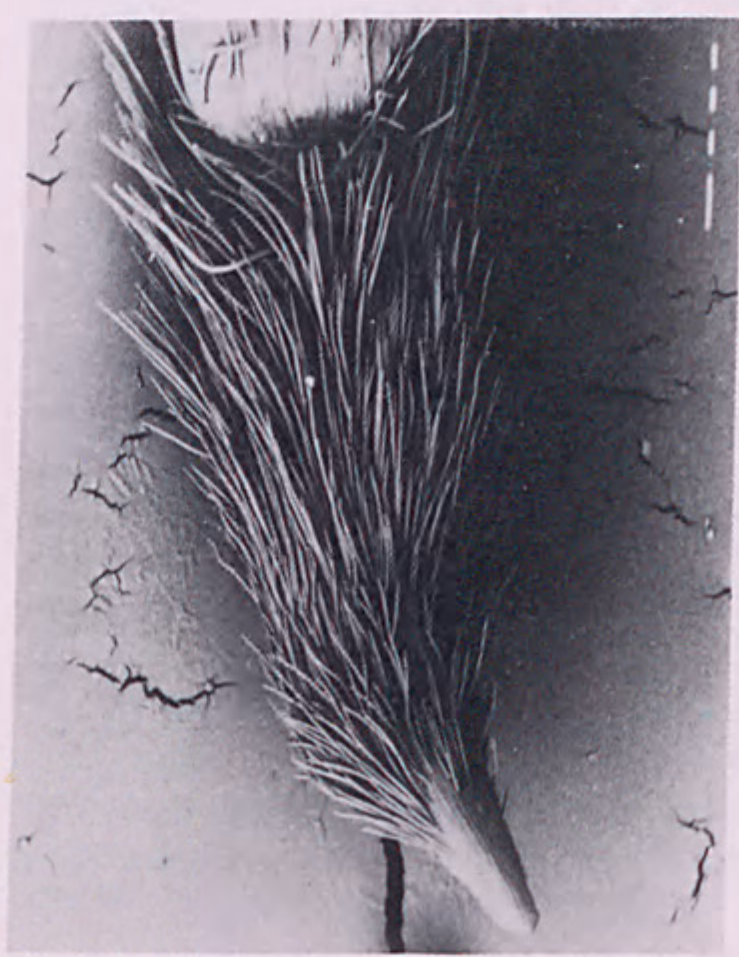

c.

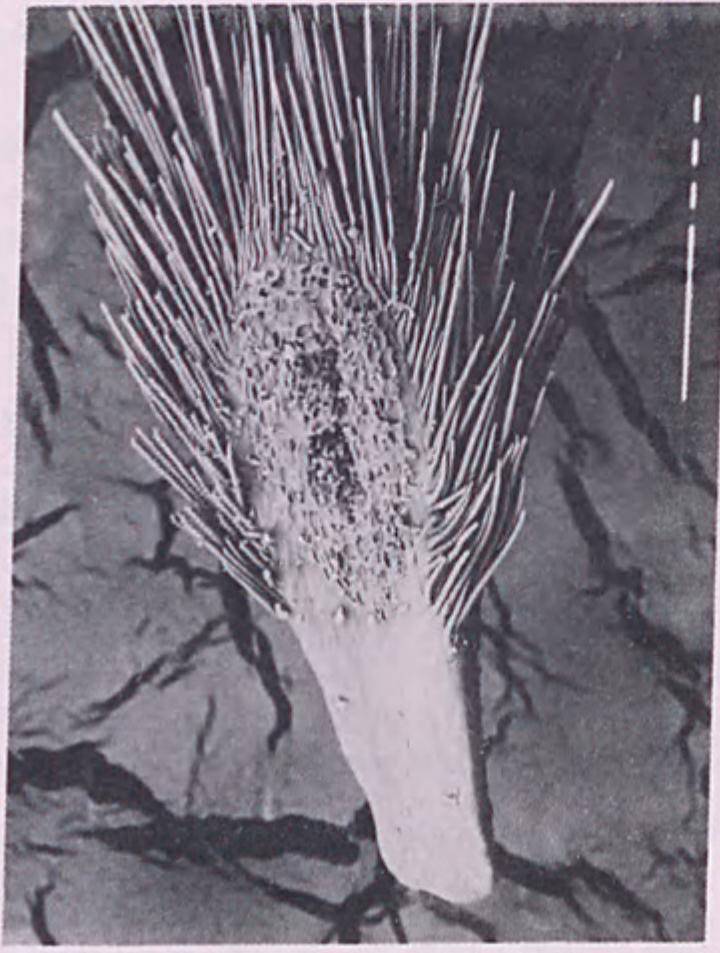

b.
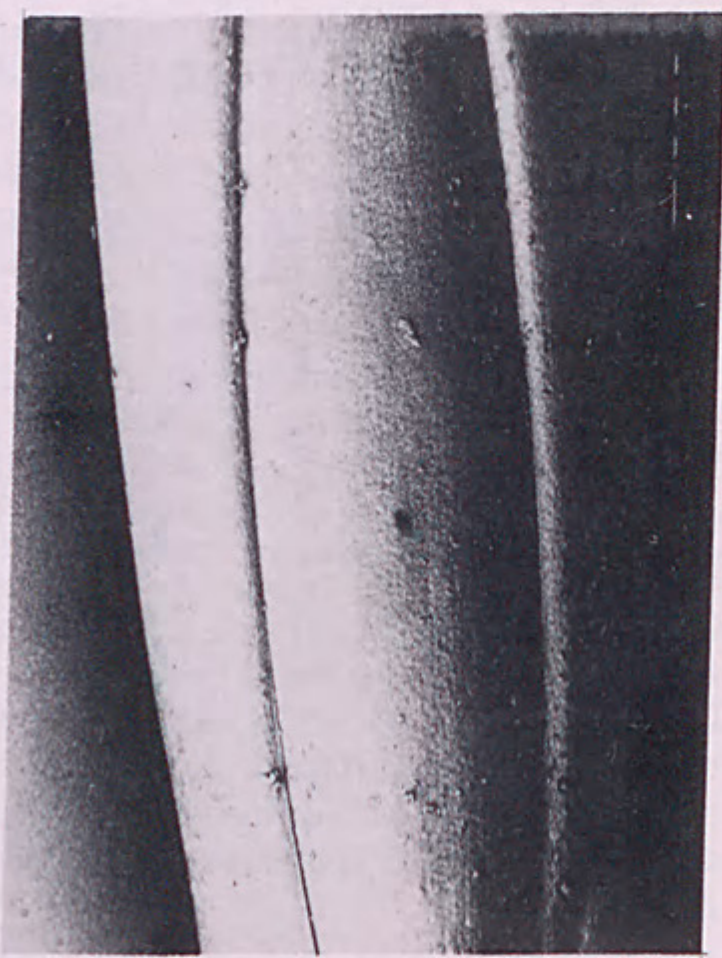

d.

Fig. 1 a. S. ramosissima showing the short, blunt callus and the lemma surface covered with short tubercles. Approx. $\times 35$, b. The callus of $S$. oligostachya showing the drawn-out tip, the vascular strand for the floret and the antrorse hairs. Lower marker bar $100 \mathrm{m \mu}$, approx. $\times 90$. c. The long callus of $S$. aphylla showing the base of the lemma, the strong, antrorse hairs and the glabrous, pungent tip. Lower marker bar $=100 \mathrm{m \mu}$, approx. $\times 35$. d. The exposed smooth palea, and the smooth lemma, with the margins not meeting, of $S$. lanata. Lower marker bar $=100 \mathrm{~m} \mu$, approx. $\times 35$. 
Floret: the floret (diaspore) includes the callus, lemma, palea and awn. In Stipa the term 'lemma' is frequently used instead of 'floret'. This usage is not uncommon in grass terminology but it is necessary to remember, perhaps more so in Stipa, that the callus, in particular, consists mainly of rhachilla tissue. Most measurements of 'lemmas' in descriptions by other authors refer to floret length but usually exclude the awn.

Callus: the callus is a prominent feature of the Stipa floret. It is mainly rhachilla but externally grades imperceptibly into the base of the lemma. The callus has an oblique disarticulation zone (Fig. 1a, b, c) which results in a pungent point at the base of the floret. In some species the callus is comparatively short, less obliquely attached, and consequently less pungent (Fig. 1a).

The hairs on the callus are antrorse, fairly stiff and usually dense. It is these hairs that seem to prevent the callus from being readily dislodged from soil, wool, skin, clothes, etc., allowing the diaspore to work its way gradually downwards or inwards. Usually there is a clear distinction between the callus hairs and the lemma hairs but, as the callus hairs are antrorse, this demarcation appears above the callus/lemma junction.

Lemma: lemma size, shape, vestiture, surface and awn features are the more important diagnostic characters. The apex of the lemma may be extended into two or, more rarely, one membranous lobe(s) above the insertion of the awn (Fig. 2a, b, c).

The lemma surface varies from quite smooth to having at least some areas almost crystalline or granular in appearance (e.g. S. rudis complex). Hairs may be almost absent (e.g. S. lanata (Fig. 1d)) to quite uniformly dense (e.g. $S$. petraea). The hairs may be distributed in a consistent pattern (e.g. $S$. eremophila, S. rudis group) (Fig. 3). Frequently longer hairs are produced near the apex of the lemma in two lateral tufts or in a more or less complete ring around the base of the awn. The 'ring' of hairs is known as a coma (Fig. 4a, $\mathrm{b}, 6 \mathrm{a})$ and its presence, length, and completeness are very useful characters. In four of the five introduced species there is a membranous cup-like growth produced in this same position (Fig. 4c, 6c). This growth is known as a corona and, while it is common in non-Australian species of Stipa, it does not occur in any Australian native species.

Awn: the awn is a prominent feature of Stipa diaspores. Even though there is an apparent disarticulation zone at the lemma/column junction, the awn is usually persistent. However, diaspores found embedded in soil or animal skins, etc., usually do not have the awn still attached and the break is at the disarticulation zone.

The awn is divided into the column and bristle. The column is the basal portion, which usually twists on drying or at maturity, and may be once or twice bent. By convention the column is defined as extending to either the second bend or to the top of the closely twisted portion if only one bend is present (Fig. $6 a, b)$.

The column length and width are useful characters as are the length and pattern of hairs. The hairs range from quite long (villous or plumose, Fig 5a) to short (scabrous, Fig. 5b), and from being present only on one side (appearing to spiral as the column twists, Fig. 5a, 6d) to present all around (Fig. 5c).

The bristle has a characteristic sickle-shape (Fig. 6b) in the group informally known as the Falcateae (approximately equivalent to the Falcateae of Hughes, 


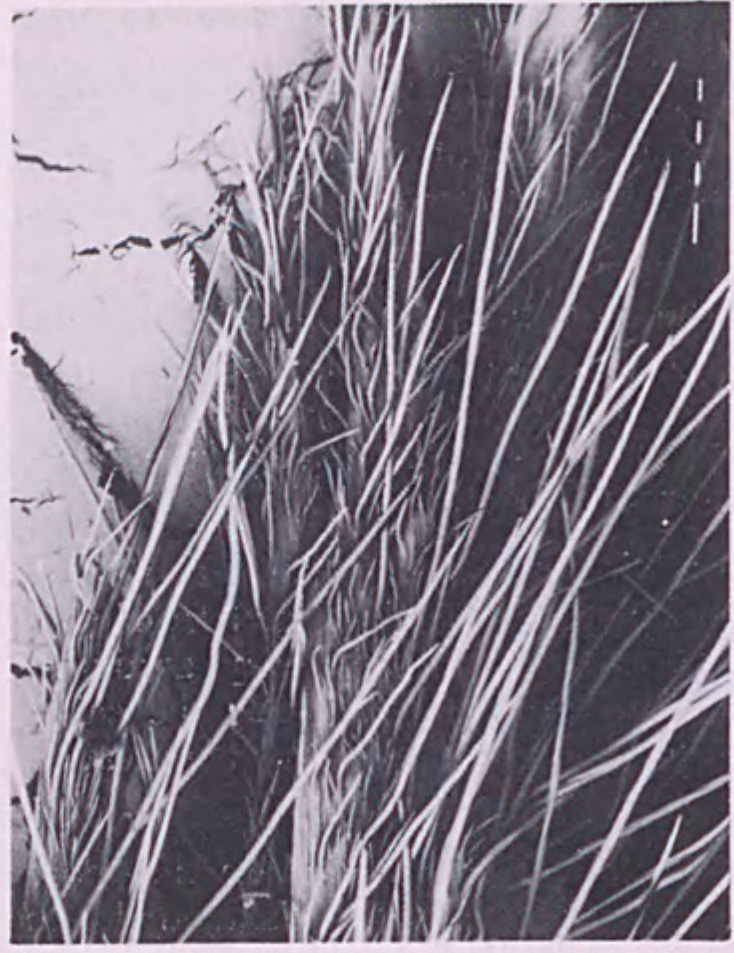

a.

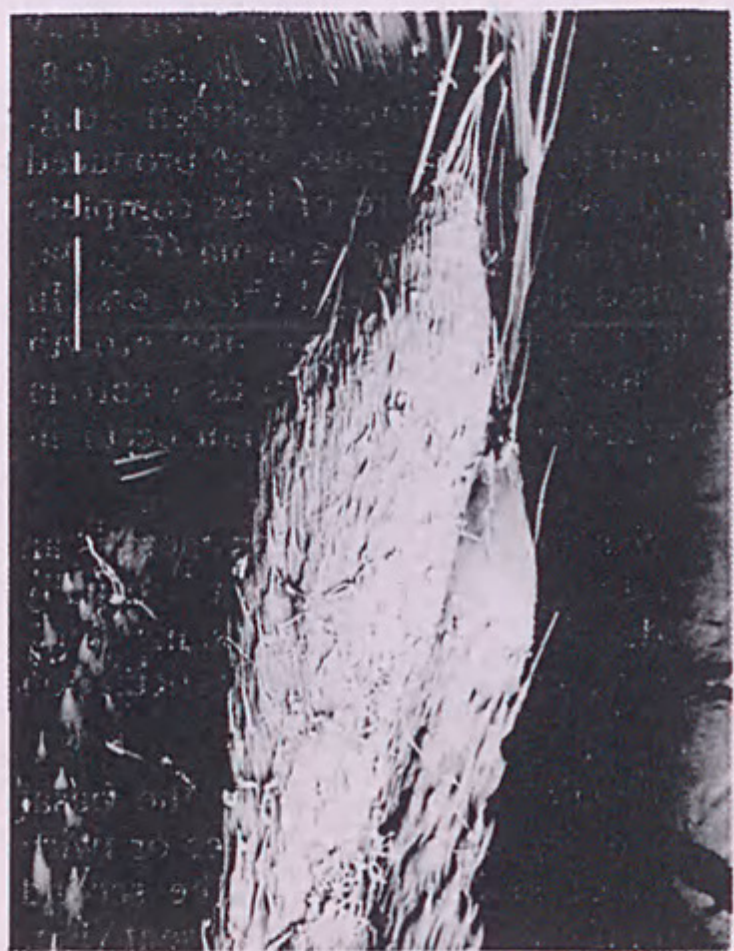

c.

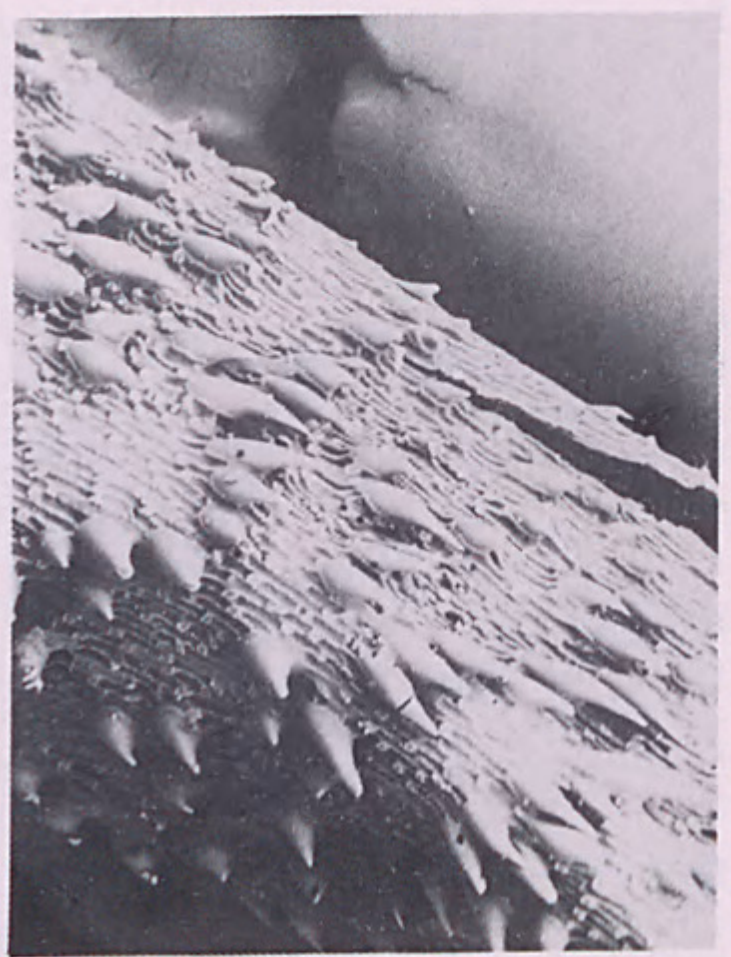

b.

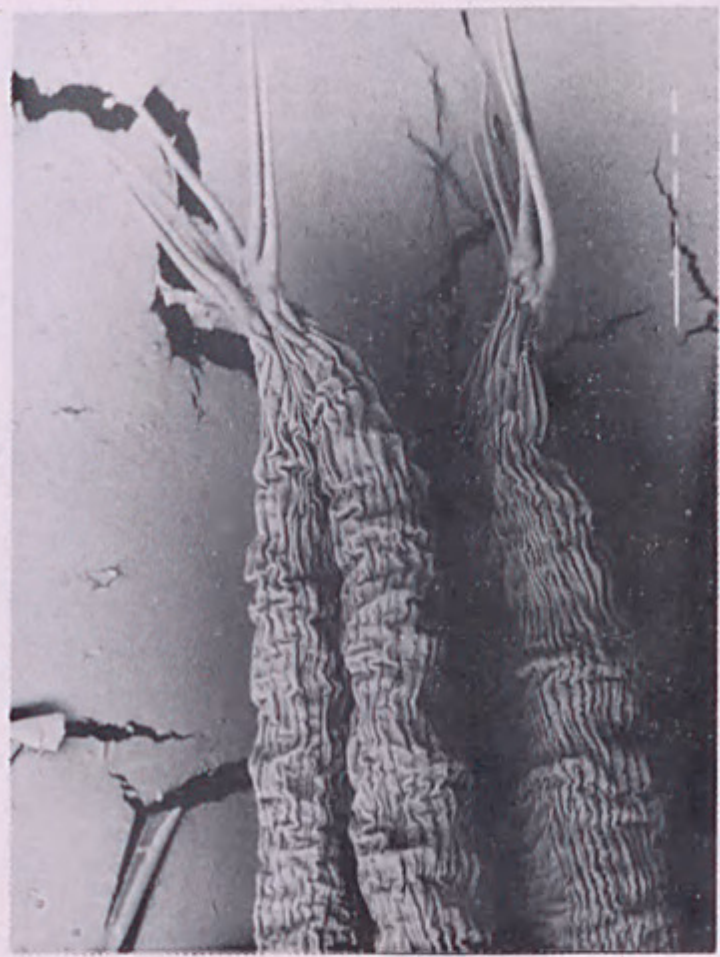

d.

Fig. 2 a. The two long, hairy lobes at the apex of the lemma of $S$. stipoides. Lower marker bar = $100 \mathrm{~m} \mu$, approx. $\times 20$. b. The minute lemma lobe of $S$. tuckeri. Approx. $\times 80$. c. The lemma lobe of $S$. oligostachya. Lower marker bar $=100 \mathrm{m \mu}$, approx. $\times 65$. d. The penicillate anthers of $S$. petraea . Lower marker bar $=100 \mathrm{~m} \mu$, approx. $\times 60$. 

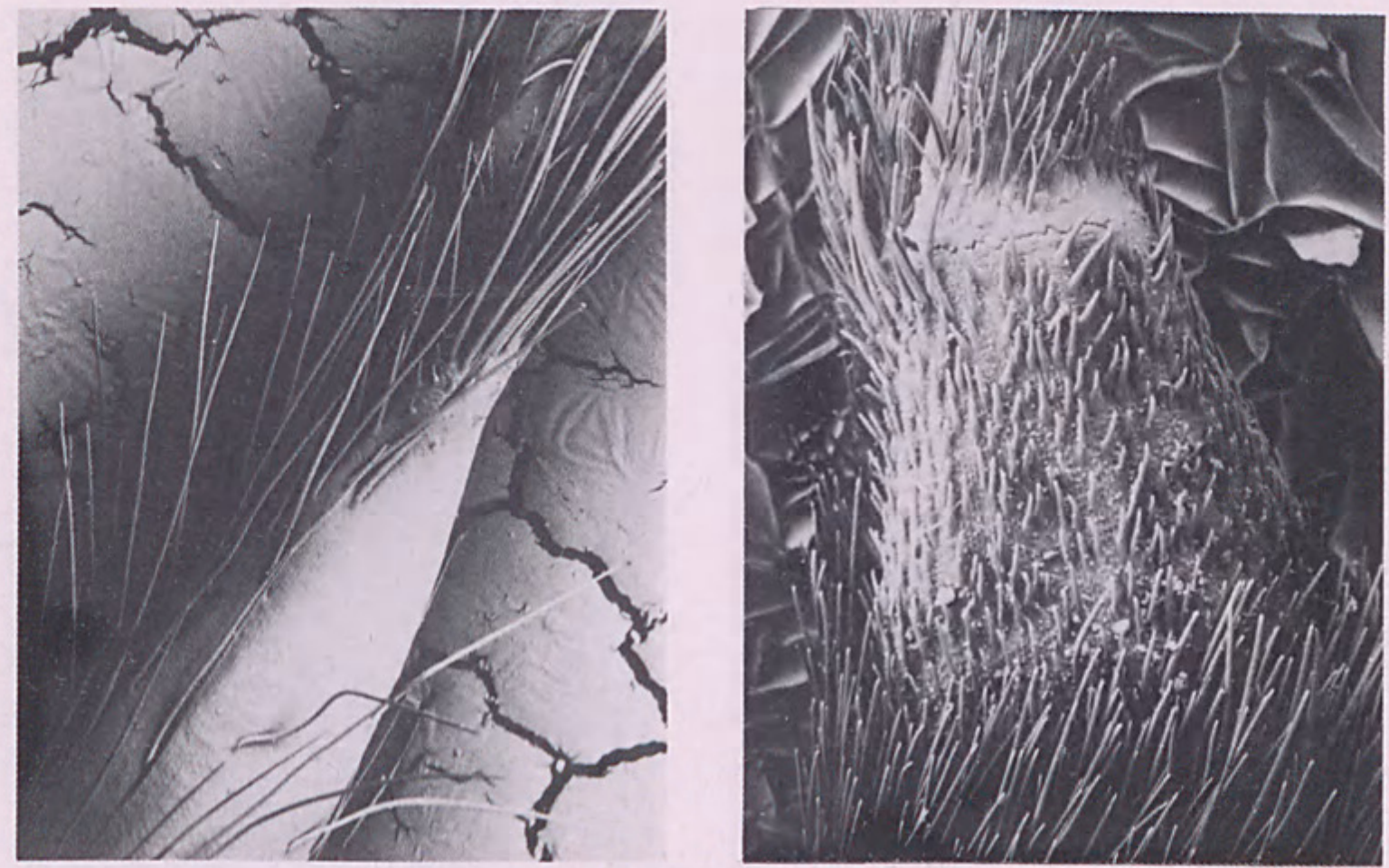

a.

b.
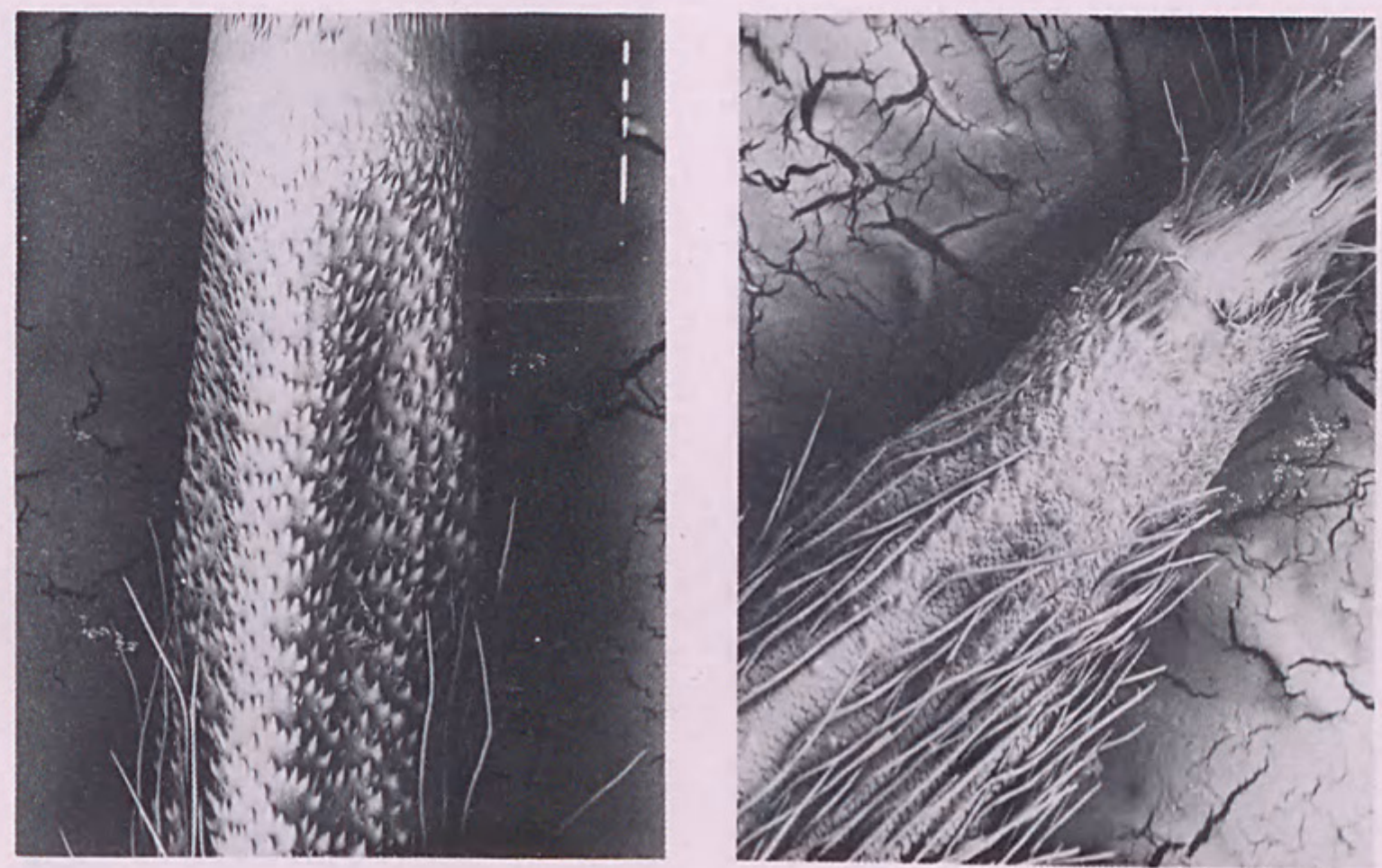

c.

d.

Fig. 3 a. The lemma of $S$. nullanulla showing the neck region with very few hairs, the line of hairs down the lemma margins, and a coma. Approx. $\times 40$. b. The neck area of the lemma of $S$. eremophila showing the well-defined patch of short hairs. Approx. $\times 25$. c. The neck area of the lemma of $S$. pubescens with a large area covered with short antrorse tubercles. Lower marker bar = $100 \mathrm{~m} \mu$, approx. $\times 30$. d. The neck area of $S$. puberula with an ill-defined zone of shorter hairs, longer hairs below, and a short lobe at the apex. Approx. $\times 180$. 


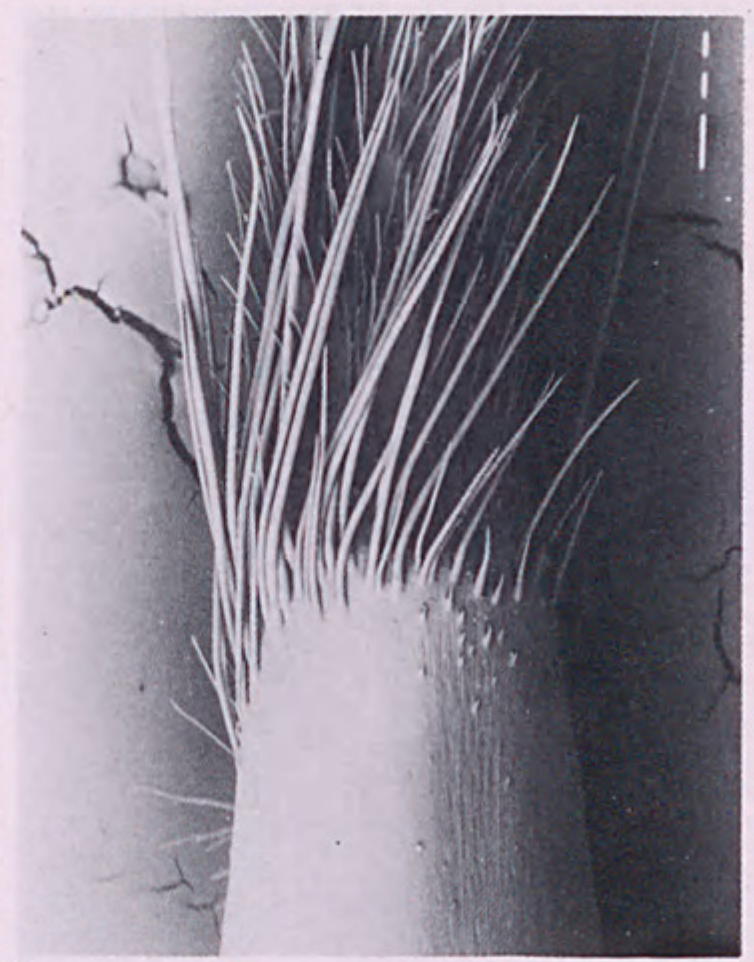

a.

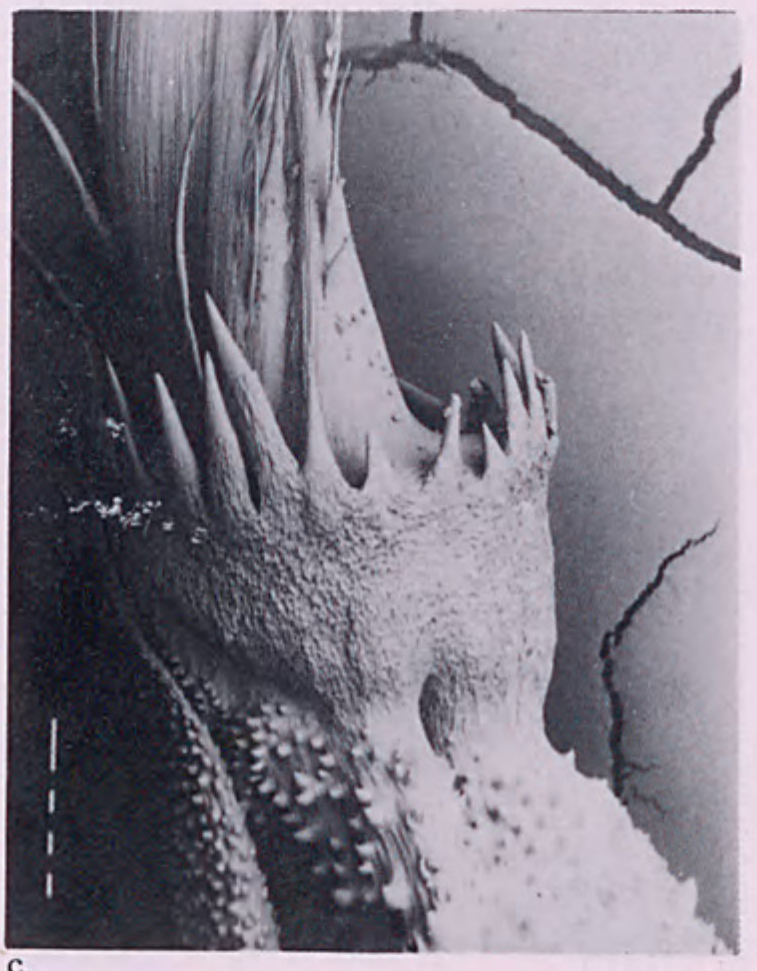

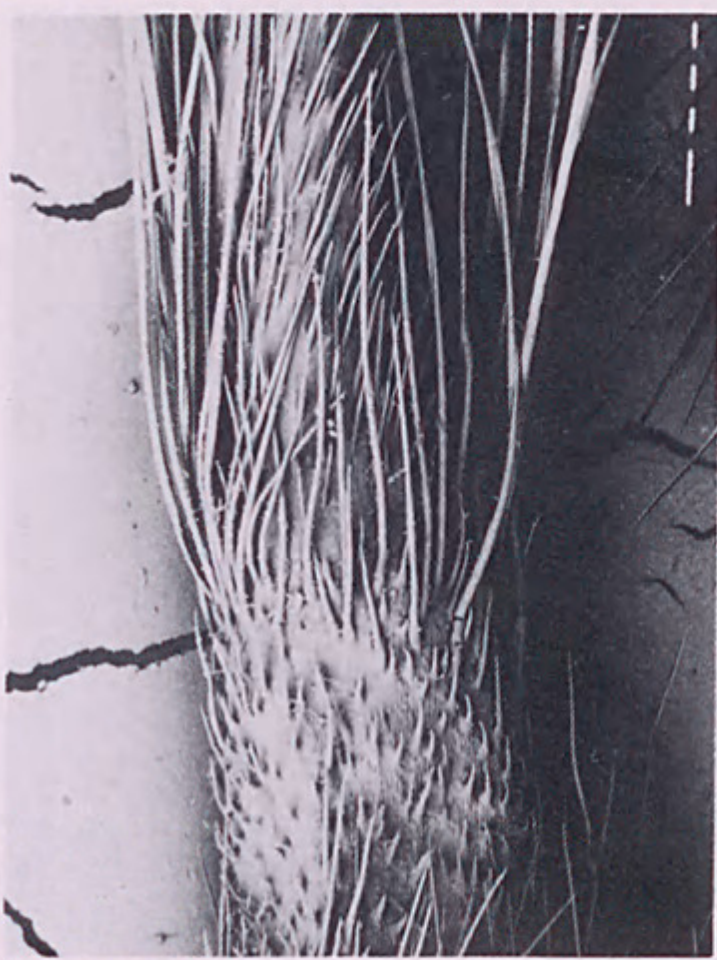

b.

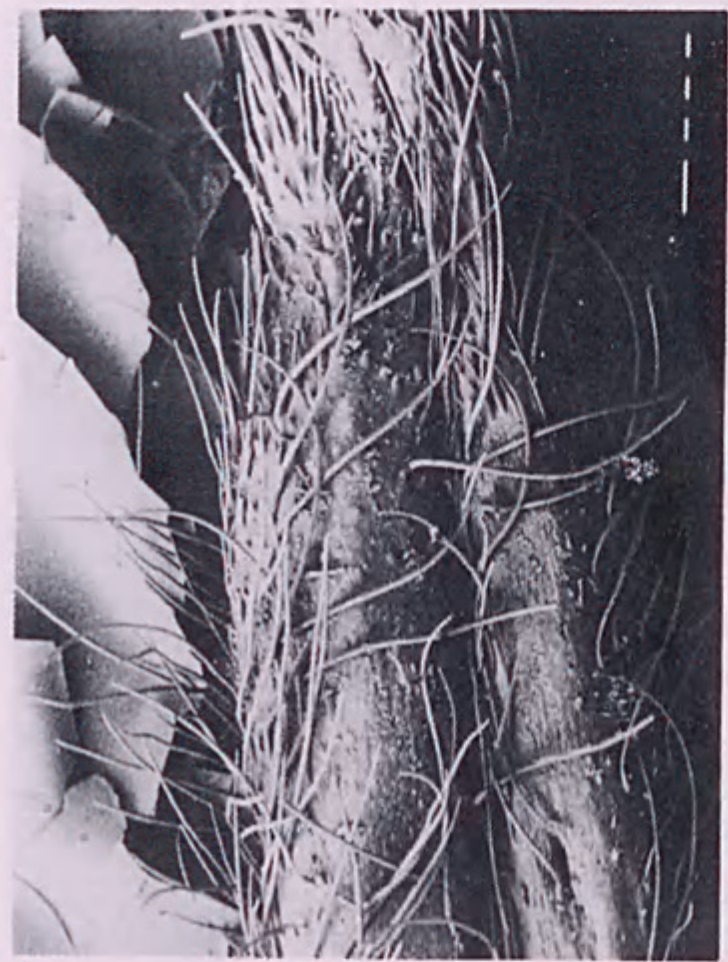

d.

Fig. 4 a. The coma of $S$. lanata. Lower marker bar $=100 \mathrm{m \mu}$, approx. $\times 30$. b. The coma, column base, and neck of $S$. metatoris. Lower marker bar $=100 \mathrm{m \mu}$, approx. $\times 30$. c. The corona at the apex of the lemma of $S$. neesiana. Upper marker bar $=100 \mathrm{~m} \mu$, approx. $\times 30$. d. The lemma of $S$. setacea showing the adaxial groove on the floret formed by the inrolled margins of the lemma exposing a small section of the palea (not visible in this print). Lower marker bar $=100 \mathrm{~m} \mu$, approx. $\times 30$. 


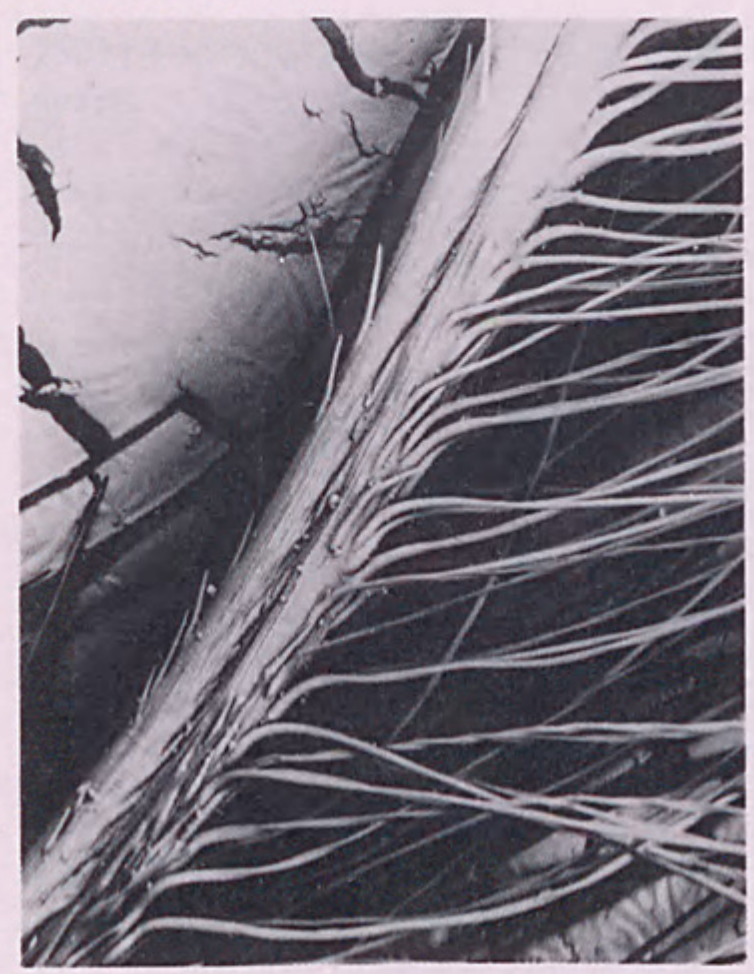

a.

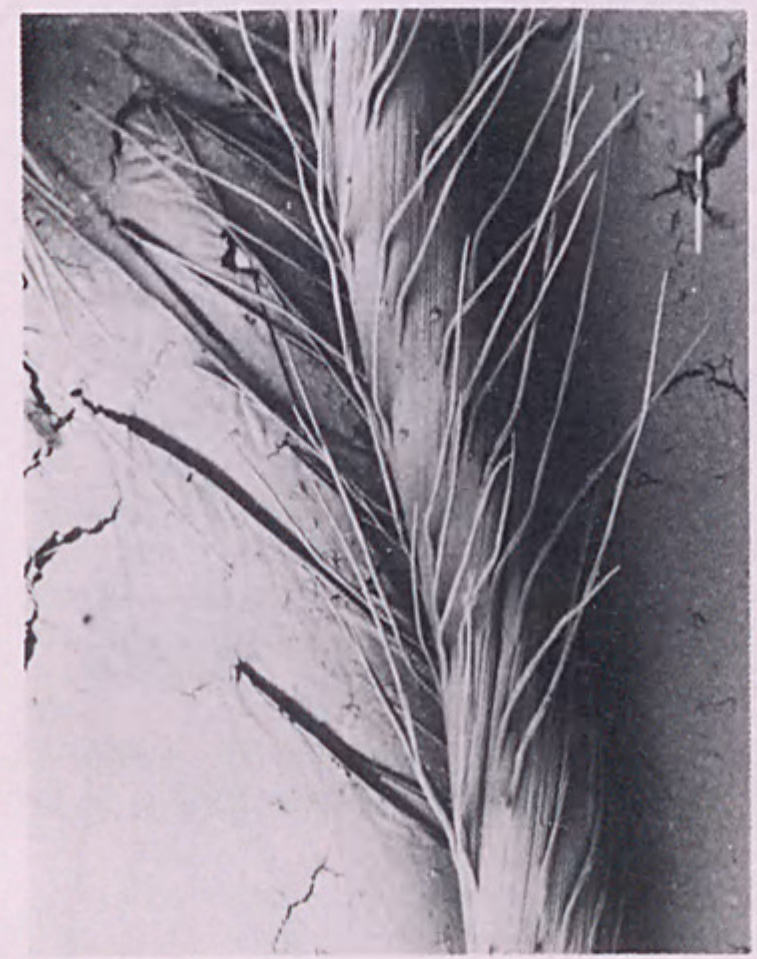

c.

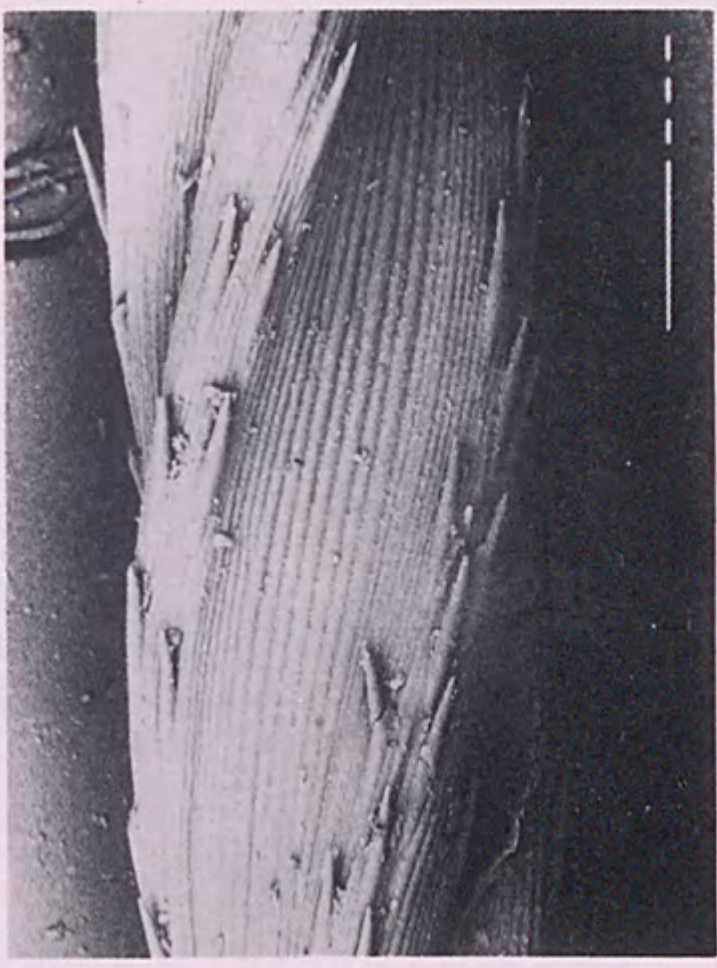

b.

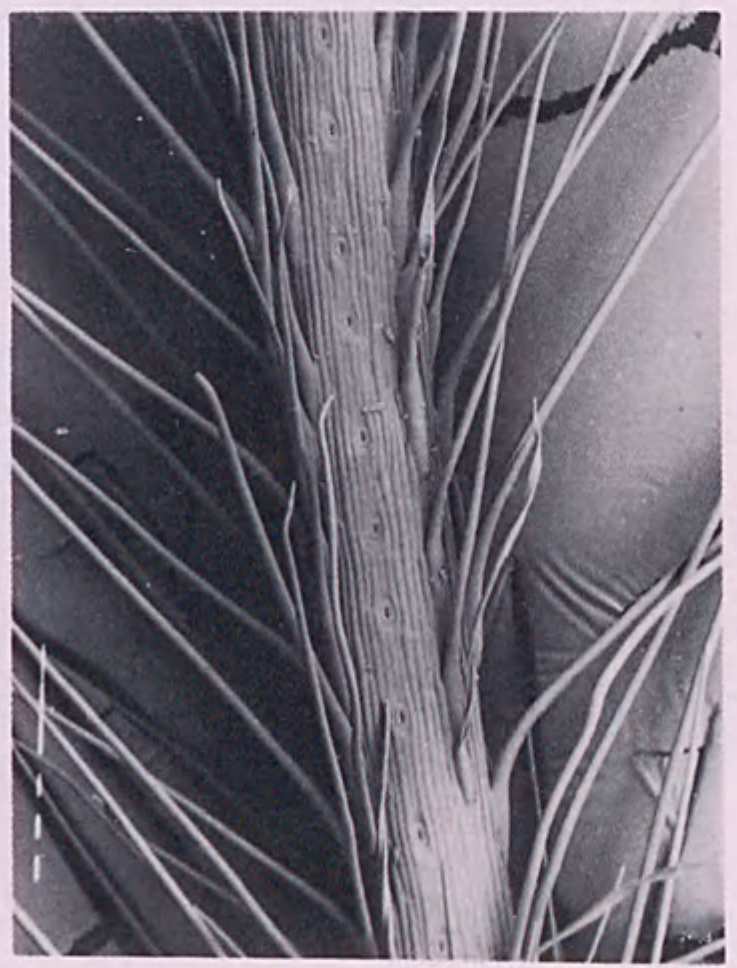

d.

Fig. 5 a. The column hairs of $S$. hemipogon with the long hairs arising on one side of the column. Approx. $\times 90$. b. The column of $S$. macalpinei with very short hairs in lines up the column. Lower marker bar $=100 \mathrm{~m} \mu$, approx. $\times 90$. c. The column of $S$. densiflora with long hairs all around the circumference. Lower marker bar $=100 \mathrm{~m} \mu$, approx. $\times 30$. d. The bristle of $S$. plumigera with the hairs arising in two bands over the fibres, and a row of stomates over the chlorenchyma. Upper marker bar $=100 \mathrm{m \mu}$, approx. $\times 60$. 


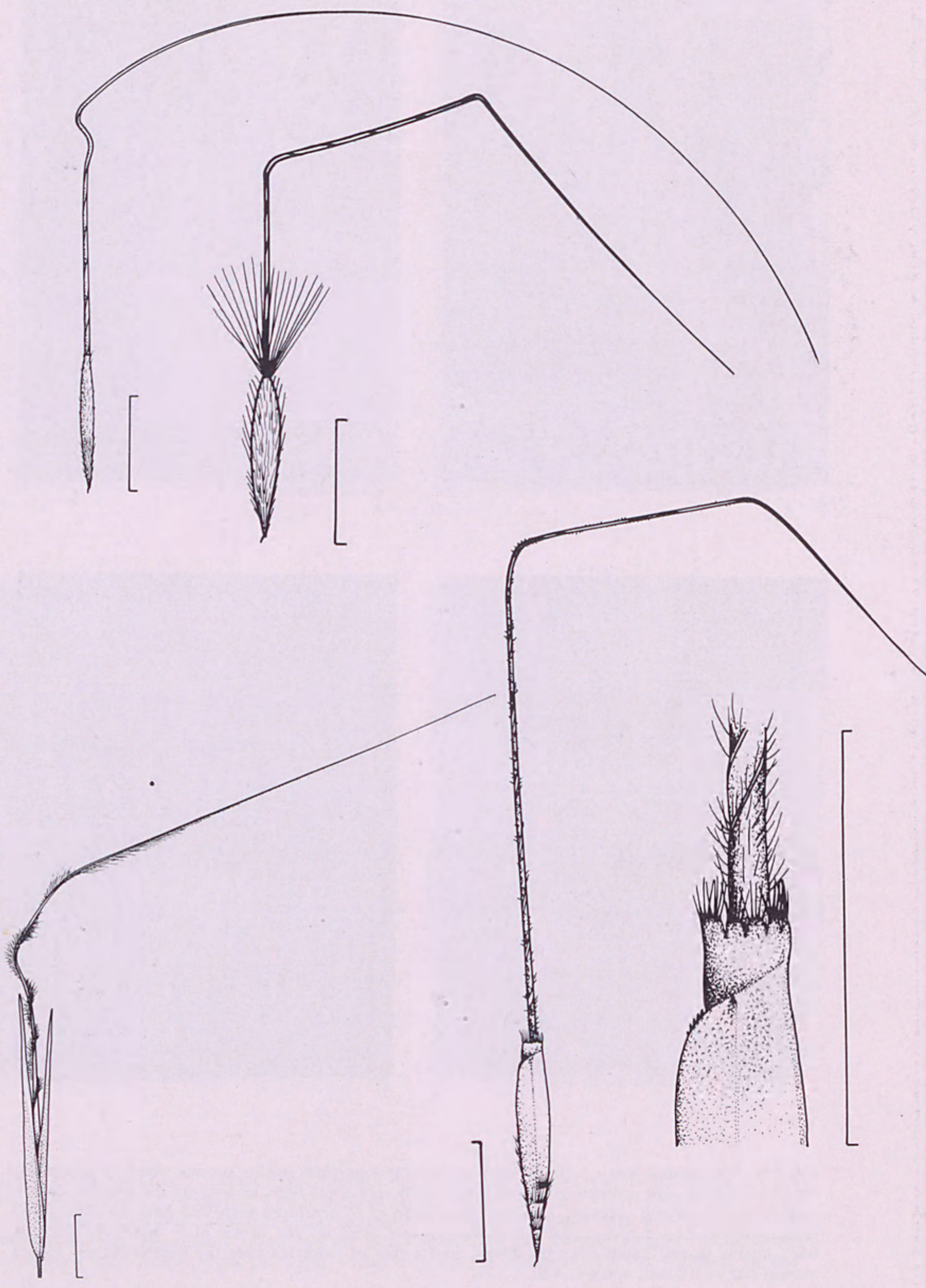


1921) and could perhaps be interpreted as the last twist in the awn. This sickleshape is more difficult to detect in pressed specimens than in the fresh state. In other species the bristle is more or less straight. Although mostly triangular in transection, the bristle may be laterally flattened; $S$. platychaeta is the extreme example here.

The hairs on the bristle are usually similar to, but shorter than, those of the column, the notable exception in Australia being the long hairs on the bristle of S. plumigera (Fig. 5d).

The anatomy of the awn is different from that in most other grasses (DuvalJouve 1871; Zimmerman 1881; Murbach 1900) and, although there have been attempts to explain the twisting and untwisting motion, more work could be usefully done on the subject. The awn in transection consists mainly of thickened cells (fibres) with two lateral pockets of chlorenchyma. The chlorenchyma breaks down with age and, apparently, the awn does not twist until this breaking-down process has been initiated.

Palea: the palea varies from about one quarter the length of the lemma to being subequal. Although the relative length of the palea is a useful diagnostic character it is awkward to observe.

Cleistogamy: spikelets are either chasmogamous or cleistogamous. In the Australian species there are no externally visible differences between the two, but the cleistogamous spikelets usually have shorter stamens. Both types may be found scattered throughout a panicle and the relative proportion of each may vary quite considerably within a particular taxon, presumably indicating a strong environmental influence on the expression of either state. The expression of cleistogamy or chasmogamy is clearly a subject worthy of further study on a population basis.

Stamens: there are three stamens per floret and the main character of use is whether the stamens are penicillate or not (Fig. 2d).

Lodicules: lodicule number is usually quoted as three in the literature and this is true for most species, the major exception being those of the Falcateae which mostly have two lodicules. When the third (the adaxial or paleal) is present its size may vary, from minute to almost equalling the palea, between spikelets in the same panicle. Normally it is either less well developed than, or similar to, the two abaxial lodicules. All are membranous, glabrous and entire; their shapes vary from lanceolate to spathulate or almost long-cuneate.

Ovary: the only ovary characters recorded are those of the caryopsis and, where possible, include the length of the mature caryopsis and the relative length of both the hilum and the embryo.

Fig. 6 (Reproduced from Wheeler, Jacobs \& Norton (1982), Grasses of New South Wales, with permission of University of New England Press). a. The floret of S. blackii showing the long coma and a bigeniculate awn. b. The floret of $S$. nodosa showing the hairy lemma and falcate awn typical of the group 'Falcateae'. c. The floret and lemma apex of S. neesiana showing the corona and bigeniculate awn. d. A spikelet of $S$. mollis showing the long glumes and the awn with hairs along one side. $\mathrm{Bar}=5 \mathrm{~mm}$. 


\section{References}

Bentham, G. (1878). 'Flora Australiensis'. Vol. 7: 564-571 (Lovell, Reeve \& Co.: London).

Duval-Jouve, J. (1871). Etude anatomique de l'arête des Graminées. Mém. Sect. Sci. Acad. Sci. Montpellier 8: 33-78.

Everett, J. \& Jacobs, S.W.L. (1983). Studies in Australian Stipa (Poaceae). Telopea 2(4): 391-400.

Hughes, D.K. (1921). A revision of the Australian species of Stipa. Kew Bull. 1921: 1-30.

Hughes, D.K. (1922). Further notes on the Australian species of Stipa. Kew Bull. 1922: 15-22.

Murbach, L. (1900). Note on the mechanics of the seed-burying awns of Stipa avenacea. Bot. Gaz. 30 (2): 113-117.

Townrow, J.E.S. (1978). The genus Stipa L. in Tasmania. Part 3-Revised taxonomy. Pap. \& Proc. Roy. Soc. Tasmania 112: 227-287.

Vickery, J.W. (1980). Four new species of Stipa (Poaceae). Telopea 2(1): 11-15.

Wheeler, D.J., Jacobs, S.W.L. \& Norton, B.E. (1982). 'Grasses of New South Wales'. (University of New England Press: Armidale.)

Zimmerman, A. (1881). Ueber mechanische Einrichtungen zur Verbreitung der Samen und Früchte mit besonderer Berücksichtigung der Torsionserscheinungen. Jahrb. Wissenschaftliche Botanik 7: 542-577. 


\section{Excluded species and names yet to be typified}

Stipa appendiculata Mez, Feddes Repert. Spec. Nov. Regni Veg. 19: 204 (1921). HOLOTYPE cited as 'Australien, ohne Angabe des Standorts und Sammlers (herb. Berl.)'. The specimen is not extant at B (nor in the Willdenow herbarium) and without evidence of either locality or collector we have not been able to trace this name.

Stipa dielsii Mez, Feddes Repert. Spec. Nov. Regni Veg. 17: 209 (1921). HOLOTYPE cited as 'Western Australia: Oldfield (Diels)'. The holotype was in B and is not extant there nor in the Willdenow herbarium. We have been unable as yet to find any specimen that could reasonably be regarded as a duplicate of the Type. The description is inadequate to determine the species being described, but could apply to $S$. flavescens.

Stipa micrantha Cav., Icon. 5: 42, fig. 467 (1799). HolOTYPE: 'Habitat in Nova-Hollandia' (MA, not seen).

= Dichelachne micrantha (Cav.) Domin; see Veldkamp, Blumea 22: 9 (1974).

Stipa pubescens var, tenuior Reader, Victorian Naturalist 17: 156 (1901). HOLOTYPE cited as 'November, 1898. Desert, Lowan'. There are several specimens in MEL with this general locality information but none bears this name and we could find no other specimen in MEL bearing this name. The specimens belong to several different species of Stipa and the description is too inadequate to give any clues.

Stipa striata Link, Hort. Berol. 1: 98 (1827). HolOTYPE cited as 'Hab. in Australia?'. The Type was in B and is not extant there nor in the Willdenow herbarium. The lack of collector information, reliable locality and adequate description makes this taxon indeterminable. 


\section{Stipa L., Sp. Pl.: 78 (1753)}

Caespitose or spreading, often rhizomatous perennials (rarely annuals). Leaves and branches either basal or cauline. Spikelets all alike, 1-flowered with the rhachilla not produced beyond the floret, hermaphrodite. Glumes persistent, hyaline to chartaceous, narrow, more or less keeled, to several $\mathrm{cm}$ long, usually acute or acuminate, less commonly muticous or mucronate, 1-5 (-7)-nerved, equal or unequal, usually longer than the floret (excluding awn). Floret articulate above the glumes, many times longer than broad, cylindrical, fusiform, pyriform or turbinate, rarely slightly gibbous, with a long, oblique, bearded, usually pungent-pointed (or rarely short and obtuse) callus. Lemma coriaceous, indurated, with convolute or involute margins usually enclosing the palea and flower, 3-5 (-7)-nerved, tapering at the tip and often, though only minutely, 1or 2-lobed, awned from the tip or between the lobes. Awn flexuose or once or twice geniculate, with a twisted column (when mature) and a straight or curved bristle, variously glabrous to plumose. Palea membranous, hyaline or somewhat indurated, 2-nerved or nerveless, subequal to or shorter than the lemma. Lodicules 3 or 2 , membranous, glabrous, lanceolate to spathulate, non-vascular. Stamens 3, frequently penicillate. Ovary glabrous; styles 2, free; stigmas plumose, tips exserted. Caryopsis fusiform-terete, tightly enclosed by the lemma and palea; the embryo about $20-35 \%$ the length of the grain; the hilum linear, nearly as long as the grain.

A large genus with probably over 300 species, mostly in temperate regions.

Type species: Stipa pennata L. HOLOTYPE: 'In Austria, Gallia' (LINN, 94.1!; possible duplicate S).

The genus contains many species that are useful fodder grasses, not so much for their intrinsic nutritive value as because they provide reasonably palatable fodder in arid regions.

Stipa tenacissima, 'Esparto Grass', of southern Europe has a strong fibre that is an important raw material for the manufacture of paper.

The diaspores are often troublesome on account of their pungent callus and twisted awn (which is hygroscopic and helps the diaspore act like a corkscrew), and may penetrate the hides, eyes and mouth-parts of livestock, causing considerable discomfort to the animals and reducing the value of their meat.

Some species are of decorative value.

Australian species of Stipa grow in virtually all non-aquatic habitats in the winter-dominated rainfall zones with a few species growing in higher altitude or arid areas of the summer-dominated rainfall zones. The genus is absent from monsoonal areas.

\section{Key 1}

1. Summit of the lemma forming a cylindrical corona $0.5-2.5 \mathrm{~mm}$ long around the base of the awn

$1^{*}$. Summit of the lemma without a corona

2. Panicle pyramidal when mature and spreading, with whorled branches, the branches and pedicels plumose with fine hairs mostly $0.5 \mathrm{~mm}$ long or longer

$2^{*}$. Panicle linear-cylindrical to ovate-cylindrical, the branches and pedicels glabrous, scabrous or pubescent with most hairs less than $0.3 \mathrm{~mm}$ long 
3. Culms branched

$3^{*}$. Culms not branched

4. Panicle reduced to 1-3 spikelets. Culms spreading and decumbent; leaf blades rudimentary (1 mm long) or deciduous .................................. Group $\mathrm{K}(\mathrm{S}$. muelleri)

4*. Panicle with more than 8 spikelets. Culms erect or geniculate at the base; leaf blades longer than $20 \mathrm{~mm}$ (deciduous in $S$. aphylla)

5. Lemma with acute, hairy lobes $1.5-3 \mathrm{~mm}$ long at the apex .......................... Group G

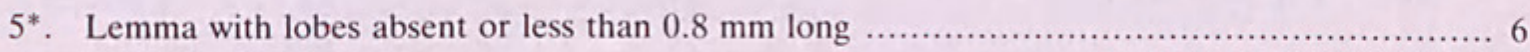

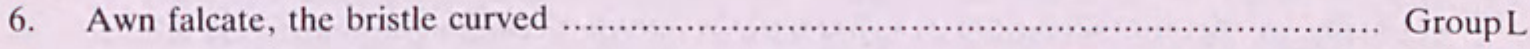

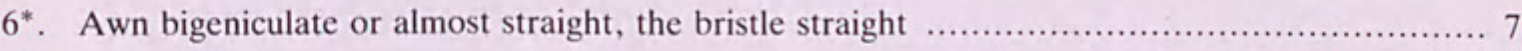

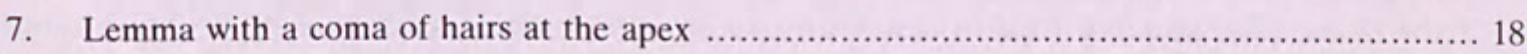

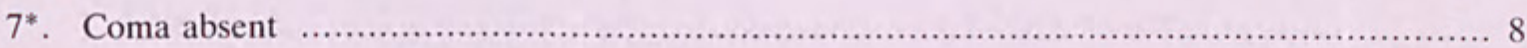

8. Column of the awn scabrous or puberulous with hairs less than $0.3 \mathrm{~mm}$ long $\ldots \ldots \ldots \ldots \ldots \ldots 12$

$8^{*}$. Column of the awn pubescent to plumose with hairs more than $0.3 \mathrm{~mm}$ long $\ldots \ldots \ldots \ldots \ldots \ldots . . \ldots$

9. Lemma glabrous except on the nerves, surface crystalline-tuberculate ................. Group H (S. oligostachya)

9*. Lemma pubescent overall, surface smooth or granular 10

10. Foliage densely and shortly velvety overall, appearing bluish Group I (S. velutina)

$10^{*}$. Foliage glabrous, scabrous or pubescent

11. Panicle not exserted above the basal leaves, sparse with less than 30 spikelets

$11^{*}$. Panicle exserted well above the basal leaves, with more than 30 spikelets Group J

12. Ligule less than $3 \mathrm{~mm}$ long

$12^{*}$. Ligule more than $3 \mathrm{~mm}$ long

13. Awn less than $45 \mathrm{~mm}$ long. Leaf sheaths and blades usually very narrow

13*. Awn 60-200 mm long. Leaf sheaths broad or narrow, blades moderately broad

14. Bristle of the awn flattened, wider at its base than the column, curved. Lemma brown, $6 \mathrm{~mm}$ long or less (excluding awn)

GroupD (S. platychaeta)

$14^{*}$. Bristle of the awn terete to triangular in transection, narrower at the base than the column, straight. Lemma white, $6.5 \mathrm{~mm}$ long or more (excluding awn)

15. Lemma glabrous for varying lengths below the apex, surface often tuberculate, especially at apex. Nerves of the glumes heavily overlaid with sclerenchyma forming strong ridges

$15^{*}$. Lemma pubescent overall, hairs occasionally sparser at the apex, surface smooth or granular. Glume nerves visible but not raised noticeably above the glume surface

16. Foliage densely and shortly velvety overall, appearing bluish Group I (S. velutina)

$16^{*}$. Foliage glabrous, scabrous or pubescent

17. Panicle not exserted above the basal leaves, sparse with less than 30 spikelets Group I (S. centralis)

17*. Panicle exserted well above the basal leaves, with more than 30 spikelets Group D

18. Lemma glabrous or almost so, surface smooth and shining Group E

$18^{*}$. Lemma pubescent, surface granular 
19. Awn $12-18 \mathrm{~mm}$ long; floret narrowly cylindrical tapering to form a neck at the apex. Glumes broadly acute

Group B (S. caudata)

$19^{*}$. Awn $20 \mathrm{~mm}$ long or more; if awn as short as $20-25 \mathrm{~mm}$ then floret broadly turbinate to oblong-cylindrical with no neck, or glumes linear and truncate

20. Glumes acuminate, very broad and inflated around the floret, sharply narrowing at the tip. Floret broadly turbinate to oblong-cylindrical; callus sturdy and strongly curved or hooked, relatively short (usually $10-30 \%$ the length of the floret); awn relatively short (usually $4.5-6.5(-8)$ times the length of the floret). Panicle expanded, usually with long branches

Group H

20*. Glumes acute or narrowly acuminate, not inflated around the floret, tapering gradually to the tip. Floret linear-cylindrical to narrowly turbinate; callus fine or sturdy, straight, only the proximal naked tip bent, relatively long (usually $25-40 \%$ the length of the floret); awn often relatively long (usually (5-) 6-13 times the length of the floret). Panicle contracted or expanded, usually with short branches

Group A: Lemma with a corona. Palea less than half the lemma length. Introduced from South America.

1. Floret about $4 \mathrm{~mm}$ long, awn $35-40 \mathrm{~mm}$ long, column minutely scabrous with hairs less than $0.05 \mathrm{~mm}$ long S. hyalina*

$1^{*}$. Floret 5.5-10 $\mathrm{mm}$ long, awn $45-85 \mathrm{~mm}$ long, column scabrous or pubescent with hairs usually more than $0.2 \mathrm{~mm}$ long

2. Corona $1.5-2.5 \mathrm{~mm}$ long with a firm basal part $0.5-1 \mathrm{~mm}$ long, upper part ciliate with thick hairs $1-1.5 \mathrm{~mm}$ long S. leucotricha*

$2^{*}$. Corona $0.5-1.5 \mathrm{~mm}$ long, with a firm basal part $0.5-1 \mathrm{~mm}$ long, upper part of spines $0.1-0.5 \mathrm{~mm}$ long

3. Lower glume $8-10 \mathrm{~mm}$ long. Floret $5.5-6 \mathrm{~mm}$ long, coronal spines about $0.1 \mathrm{~mm}$ long S. megapotamia*

$3^{*}$. Lower glume $14-18 \mathrm{~mm}$ long. Floret $6-10 \mathrm{~mm}$ long, coronal spines about $0.5 \mathrm{~mm}$ long S. neesiana*

Group B: Cleistogenes present in the basal sheaths. Introduced from South America.

One species S. caudata*

Group C: Panicle pyramidal with whorled branches. Palea less than half the lemma length.

1. Branches of the panicle plumose with hairs $1.5-2 \mathrm{~mm}$ long. Culms glabrous. Glumes pilose on the nerves, scabrous between the nerves S. elegantissima

$1^{*}$. Branches of the panicle plumose with hairs about $0.5 \mathrm{~mm}$ long. Culms pubescent around the nodes. Glumes scabrous overall 
Group D: Culms usually branched. Leaves with long ligules. Panicle large, sparse and spreading.

1. Callus $0.5 \mathrm{~mm}$ long or less, blunt. Palea $60 \%$ the length of the lemma or less

$1^{*}$. Callus $0.5 \mathrm{~mm}$ long or more, sharp. Palea more than $60 \%$ the length of the lemma

2. Lower glume $4-5.5 \mathrm{~mm}$ long. Floret $3-4 \mathrm{~mm}$ long S. nullarborensis

$2^{*}$. Lower glume 6-15 mm long. Floret $4.5-6.5 \mathrm{~mm}$ long 3

3. Bristle quite flattened, distinctly wider at its base than the column, strongly curved. Column scabrous S. platychaeta

$3^{*}$. Bristle round-triangular in transection, as wide as or narrower at the base than the column, straight. Column pubescent S. acrociliata

4. Culms sturdy, simply branched at the nodes. Lower glume more than $5 \mathrm{~mm}$ long $S$. breviglumis

4*. Culms cane-like with whorled branches at the nodes. Lower glume $5 \mathrm{~mm}$ long or less 5

5. Lemma glabrous, $1.8-2.5 \mathrm{~mm}$ long S. ramosissima

$5^{*}$. Lemma scattered with short white hairs, $2.7-4 \mathrm{~mm}$ long S. verticillata

Group E: Lemma glabrous or almost so, the surface shining.

1. Lower glumes $19-26 \mathrm{~mm}$ long. Ligule $0.4-1.5 \mathrm{~mm}$ long S. lanata

$1^{*}$. Lower glumes less than $18 \mathrm{~mm}$ long. At least some ligules more than $2 \mathrm{~mm}$ long 2

2. Lower glume $14-18 \mathrm{~mm}$ long. Awn (8-) 9-12.5 cm long S. vickeryana

2*. Lower glume 9-11 mm long. Awn 5-7 cm long S. nullanulla

Group F: Apparently annuals with very broad leaves. Lemma white with a long, almost straight awn.

1. Leaf sheaths covered with transparent, flattened and flexuose hairs although these sometimes visible only on lower sheaths S. macalpinei

$1^{*}$. Leaf sheaths glabrous or minutely scaberulous S. compressa

Group G: Lemma with long, acute lobes at the apex.

1. Panicle reduced to $1-3$ spikelets. Culms spreading and decumbent S. muelleri

$1^{*}$. Panicle with more than 8 spikelets. Culms caespitose and erect

2. Ligule 0.1-1 mm long, truncate. Mature lemma with fulvous hairs S. petraea

$2^{*}$. Ligule $2.5-10 \mathrm{~mm}$ long, obtuse. Mature lemma with white to slightly yellow hairs 3

3. Lower glume $10-12 \mathrm{~mm}$ long. Floret $6.5-8 \mathrm{~mm}$ long; awn long with respect to floret, 3-6 mm long. Panicle usually slightly expanded, $3.5-8.5 \mathrm{~cm}$ wide (excluding awns), sparse and open with longest branches $8-10 \mathrm{~cm}$ long S. juncifolia

$3^{*}$. Lower glume (12-) 14-20 mm long. Floret 8-13 mm long; awn very short with respect to floret length, 2-4 mm long. Panicle contracted, $1-3.5 \mathrm{~cm}$ wide (excluding awns), condensed with longest branches up to $5 \mathrm{~cm}$ long S. stipoides 
Group H: Glumes very broad and inflated around the floret. Lemma with a coma and a short, strongly hooked callus. Panicle expanded with long branches.

1. Lemma glabrous except on the nerves, surface crystalline-tuberculate S. oligostachya

$1^{*}$. Lemma with hairs overall, surface granular

2. Ligule $2-8 \mathrm{~mm}$ long, usually more than $3.5 \mathrm{~mm}$ long. Palea with a deep adaxial central groove

$2^{*}$. Ligule $2 \mathrm{~mm}$ long or less. Palea convex on the adaxial surface or only very slightly depressed between the nerves

3. Coma 2-3 (-5) mm long. Foliage of the lower leaves pubescent or hirsute

$3^{*}$. Coma $2 \mathrm{~mm}$ long or less; if $2 \mathrm{~mm}$ then foliage of the lower leaves scabrous or glabrous, not noticeably pubescent

4. Column of the awn long-pubescent with most hairs $0.5-1.5 \mathrm{~mm}$ long; awn $30-40 \mathrm{~mm}$ long. Nullarbor Plain

$4^{*}$. Column of the awn scabrous or pubescent with hairs less than $0.5 \mathrm{~mm}$ long; if pubescent then awn more than $45 \mathrm{~mm}$ long

5. Column of the awn pubescent with spreading hairs $0.25-0.5 \mathrm{~mm}$ long. Coma $0.5-1 \mathrm{~mm}$ long. Auricles with tufts of hairs $1 \mathrm{~mm}$ long S. curticoma

$5^{*}$. Column of the awn scabrous with hairs less than $0.2 \mathrm{~mm}$ long. Coma $0.4-2 \mathrm{~mm}$ long; if less than $1.3 \mathrm{~mm}$ long then auricles glabrous

6. Mature floret fusiform; callus $0.4-1(-1.5) \mathrm{mm}$ long, very short with respect to the floret ((5.8-) 6.5-8 mm long). Ligule $0.8-1.5 \mathrm{~mm}$ long

6*. Mature floret oblong-cylindrical; callus $1-2.5 \mathrm{~mm}$ long, long with respect to the floret (4.5-8.5 (-9.5) $\mathrm{mm}$ long). Ligule $0.3-0.5 \mathrm{~mm}$ long (not including auricles)

7. Coma $0.8-1.3 \mathrm{~mm}$ long. Floret $4.5-6 \mathrm{~mm}$ long (excluding awn), gibbous with an eccentric awn; awn 25-35 (-50) mm long

$7^{*}$. Coma (1.2-) 1.4-2 mm long. Floret 6-8.5 (-9.5) mm long (excluding awn); awn centric, 30-60 $\mathrm{mm}$ long S. bigeniculata

8. Floret 3-4.5 mm long, awn 12-18 mm long S. feresetacea

$8^{*}$. Floret $5.5-7 \mathrm{~mm}$ long, awn $25-40 \mathrm{~mm}$ long S. setacea

Group I: Glumes narrow, close around the floret. Lemma with a coma and a long, fine and straight callus. Panicle often contracted, with short branches.

1. Floret with a dense and obvious coma $2-3.5 \mathrm{~mm}$ long

$1^{*}$. Floret with a coma $1.5 \mathrm{~mm}$ long or less, often obscure

2. Leaves rigidly erect and pungent-pointed. Awn $90-110 \mathrm{~mm}$ long, the column $30-35 \mathrm{~mm}$ long

2*. Leaves erect or flexuose, acute-tipped but not pungent. Awn 23-90 (-110) mm long, the column usually less than $30 \mathrm{~mm}$ long (but longer in $S$. eremophila) 
3. Entire awn plumose (including the bristle) with hairs $0.5-1 \mathrm{~mm}$ long

S. plumigera

$3^{*}$. Column of the awn scabrous, pubescent or villous, bristle scabrous or shortly pubescent with hairs less than $0.3 \mathrm{~mm}$ long

4. Hairs on the lemma continued evenly to the apex, white or slightly fulvous at maturity. Floret linear-cylindrical to narrow-turbinate with no neck

$4^{*}$. Hairs on the top 1-2 $\mathrm{mm}$ of the lemma abruptly shorter by about half than those on the lower part of the lemma, fulvous early in development. Floret broad turbinate to broad oblong-cylindrical with a neck

5. Lower glume 8-12 mm long. Column of the awn scabrous with hairs $0.05-0.1 \mathrm{~mm}$ long

S. puberula

$5^{*}$. Lower glume $15-25 \mathrm{~mm}$ long. Column of the awn pubescent with hairs $0.2-0.4 \mathrm{~mm}$ long

S. eremophila

6. Foliage bluish, densely and shortly velvety overall

S. velutina

$6^{*}$. Foliage green, scabrous, pubescent or hirsute, the individual hairs discretely seen

7. Panicle not exserted above the basal leaves S. centralis

7*. Panicle exserted well above the basal leaves 8

8. Lower glume $15-23 \mathrm{~mm}$ long. Column of the awn villous with hairs $0.5-1 \mathrm{~mm}$ long. Leaf sheaths usually hirsute or pubescent especially near the base. Panicle $20-35 \mathrm{~cm}$ long

$8^{*}$. Lower glume $17 \mathrm{~mm}$ long or less. Column of the awn scabrous, pubescent or villous; if villous then leaf sheaths scabrous or minutely puberulous and panicle up to $12 \mathrm{~cm}$ long

9. Culms slender, up to $1 \mathrm{~mm}$ wide near the base. Panicle 6-18 $\mathrm{mm}$ long, sparse. Ligule $0.3-3 \mathrm{~mm}$ long, the abaxial surface glabrous or minutely puberulous

9*. Culms sturdy, (1.5-) 3-4 mm wide near the base. Panicle $15-40 \mathrm{~mm}$ long, dense. Ligule $0.3-0.7 \mathrm{~mm}$ long, the abaxial surface sericeous

10. Lower glume $8.5-10 \mathrm{~mm}$ long. Callus $0.5-1.2 \mathrm{~mm}$ long. Awn $25-40 \mathrm{~mm}$ long

S. multispiculis

$10^{*}$. Lower glume 9-14 (-16) mm long. Callus 1.6-3 mm long. Awn (35-) 40-65 mm long

S. flavescens

11. Lower glume 8-10 mm long. Leaves pubescent, fine and flexuose S. exilis

$11^{*}$. Lower glume 12-17 mm long. Leaves almost glabrous, sturdy and erect S. mundula

12. Column of the awn villous with hairs $0.5-1 \mathrm{~mm}$ long S. stuposa

$12^{*}$. Column of the awn scabrous or pubescent with hairs $0.3 \mathrm{~mm}$ long or less 13

13. Coma spreading, formed from the spreading upper hairs of the lemma overlapping the base of the awn and hiding the awn/lemma junction. Awn $23-38 \mathrm{~mm}$ long, the column $7-12 \mathrm{~mm}$ long

$13^{*}$. Coma appressed, formed by hairs at the awn/lemma junction, the junction discernible. Awn 35-65 mm long, the column $15-25 \mathrm{~mm}$ long

14. Lower glume $11-15 \mathrm{~mm}$ long. Lemma $5.5-6.5 \mathrm{~mm}$ long S. wakoolica

$14^{*}$. Lower glume $16-20 \mathrm{~mm}$ long. Lemma $7-8.2 \mathrm{~mm}$ long

S. metatoris 
Group J: Column of the awn plumose or long-pubescent. Lemma usually without a coma.

1. Distinct coma 1-3 $\mathrm{mm}$ long present at the apex of the lemma in addition to the hairs on the column

$1^{*}$. No coma present

2. Column hairs $0.3-1 \mathrm{~mm}$ long, spreading, evenly distributed around the column and therefore not appearing to spiral

$2^{*}$. Column hairs $1-4 \mathrm{~mm}$ long, slightly appressed, distributed mainly along the ribs and thereby appearing to spiral with the spiralling column

$3^{i}$. Upper glume 9-10 mm long, floret 3.5-5 mm long. Central Australian Ranges S. aquarii

$3^{\text {ii }}$. Upper glume $10-15 \mathrm{~mm}$ long, floret $5-7 \mathrm{~mm}$ long

S. hemipogon

$3^{\text {iii }}$. Upper glume $15-20 \mathrm{~mm}$ long, floret $7.5-8.5 \mathrm{~mm}$ long S. mollis

4. Glumes glabrous except on the nerves. Awn $70-90 \mathrm{~mm}$ long. Leaves scabrous or glabrous

S. semibarbata

$4^{*}$. Glumes pubescent. Awn less than $60 \mathrm{~mm}$ long. Leaves hirsute 5

5. Floret 8-9 mm long, awn 50-70 $\mathrm{mm}$ long S. campylachne

$5^{*}$. Floret 5.5-7 mm long, awn 35-45 $\mathrm{mm}$ long S. densiflora

Group K: Lemma glabrous for varying lengths below the apex, the surface rough. Glumes strongly ridged.

1. Lemma glabrous except on the nerves, strongly crystalline-tuberculate overall, pale until advanced in maturity S. oligostachya

$1^{*}$. Lemma with hairs not restricted to the nerves, tuberculate mainly towards the apex, light brown early in maturity

2. Culms spreading and decumbent. Leaf blades $1 \mathrm{~mm}$ long or deciduous. Panicle reduced to $1-3$ spikelets S. muelleri

$2^{*}$. Culms caespitose and erect or geniculate. Leaf blades more than $20 \mathrm{~mm}$ long (deciduous in $S$. aphylla). Panicle of more than 8 spikelets 3

3. Spikelets 8-12 per panicle. Column of the awn $55-70 \mathrm{~mm}$ long. Subalpine grass ...... S. nivicola

$3^{*}$. Spikelets more than 12 per panicle. Column of the awn less than $55 \mathrm{~mm}$ long

4. Almost all blades deciduous before flowering. Glumes tapering to a fine acuminate or dentate tip S. aphylla

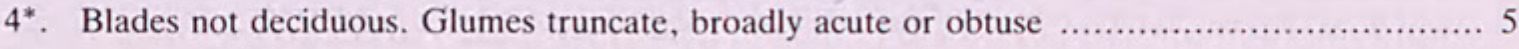

5. Lower glume $15 \mathrm{~mm}$ long or less S. rudis

$5^{*}$. Lower glume $17 \mathrm{~mm}$ long or more

6. Ligule truncate, $0.4-1 \mathrm{~mm}$ long. Glumes truncate. Lemma surface strongly tuberculate at the apex. Palea $50-70 \%$ the length of the lemma, obtuse S. pubescens

$6^{*}$. Ligule obtuse, $1-3 \mathrm{~mm}$ long. Glume tips broadly obtuse and membranous. Lemma surface granular. Palea equal in length to the lemma, acute 
Group L: Awn falcate. Lemma narrow and needle-like.

1. Inflorescence short, very dense and spike-like, to $14 \mathrm{~cm}$ long, $1 \mathrm{~cm}$ wide (excluding awns). Ligule 3-7 mm long. Shoots extravaginal from a short rhizome S. pycnostachya

$1^{*}$. Inflorescence to $55 \mathrm{~cm}$ long, variably contracted or expanded but not spike-like. Ligule usually less than $3 \mathrm{~mm}$ long (occasionally to $4 \mathrm{~mm}$ in $S$. scabra). Shoots intravaginal or extravaginal but with no rhizome

2. Awns long-pubescent or plumose with spreading hairs, most of which are $0.25-0.8$ $(-1.5) \mathrm{mm}$ long

2*. Awns scabrous or puberulous with appressed hairs, most of which are $0.2 \mathrm{~mm}$ long or less

3. Leaves very fine: sheaths $2-5 \mathrm{~mm}$ wide; blades $0.6-1.2 \mathrm{~mm}$ wide, inrolled, usually flexuose

$3^{*}$. Leaves coarse: sheaths (3-) 4.5-9 mm wide; blades 1-3 mm wide, inrolled and erect or expanded and flexuose

4. Leaf sheaths softly pilose; blades with dense, long $(\geqslant 0.5 \mathrm{~mm})$ spreading hairs $S$. trichophylla

4*. Leaf sheaths glabrous, scabrous or puberulous; blades glabrous, scabrous or shortly pubescent with most hairs less than $0.5 \mathrm{~mm}$ long

S. scabra

5. Panicle contracted, usually dense. Innovations mostly intravaginal. Nodes mostly concealed by the sheaths

$5^{*}$. Panicle spreading, usually sparse. Innovations mostly extravaginal. Nodes exserted and conspicuous

6. Spikelet small in most parts: lower glume $8-14 \mathrm{~mm}$ long, upper glume $6-12.5 \mathrm{~mm}$ long; floret 4-6.5 (-7) $\mathrm{mm}$ long; awn 38-90 mm long, delicate $(0.2-0.3(-0.4) \mathrm{mm}$ wide near the base), gently falcate

$6^{*}$. Spikelet large in most parts: lower glume $14-20 \mathrm{~mm}$ long, upper glume $11.5-18 \mathrm{~mm}$ long; floret 7-8 mm long; awn 70-100 mm long, sturdy $(0.3-0.4 \mathrm{~mm}$ wide near the base), very strongly falcate

7. Auricles glabrous or with few short hairs

S. blakei

$7^{*}$. Auricles hirsute with a dense line of long white hairs S. tenuifolia

8. Leaf blades broad, $2-6 \mathrm{~mm}$ wide $(0.8-2 \mathrm{~mm}$ diameter if inrolled), erect 9

$8^{*}$. Leaf blades fine $(0.3-0.6 \mathrm{~mm}$ diameter, usually inrolled), usually slightly flexuose 10

9. Leaves pungent, sheaths narrow and tightly enveloping the culm. Nodes exserted. Panicle contracted. Awn 40-50 mm long

9*. Leaves acute but not pungent, sheaths broad and loose around the culm. Nodes rarely exserted. Panicle expanded. Awn (40-) 60-90 mm long S. drummondii

10. Leaf blades densely hirsute. Column of the awn to $10 \mathrm{~mm}$ long. Glumes unequal

S. trichophylla

$10^{*}$. Leaf blades mostly glabrous or scabrous (occasionally the very basal blades hirsute). Column of the awn 11-14 mm long. Glumes subequal S. variabilis 


\section{Key 2, Multiple-entry}

Part 1: Species with straight or geniculate awns sc. $=$ scabrous

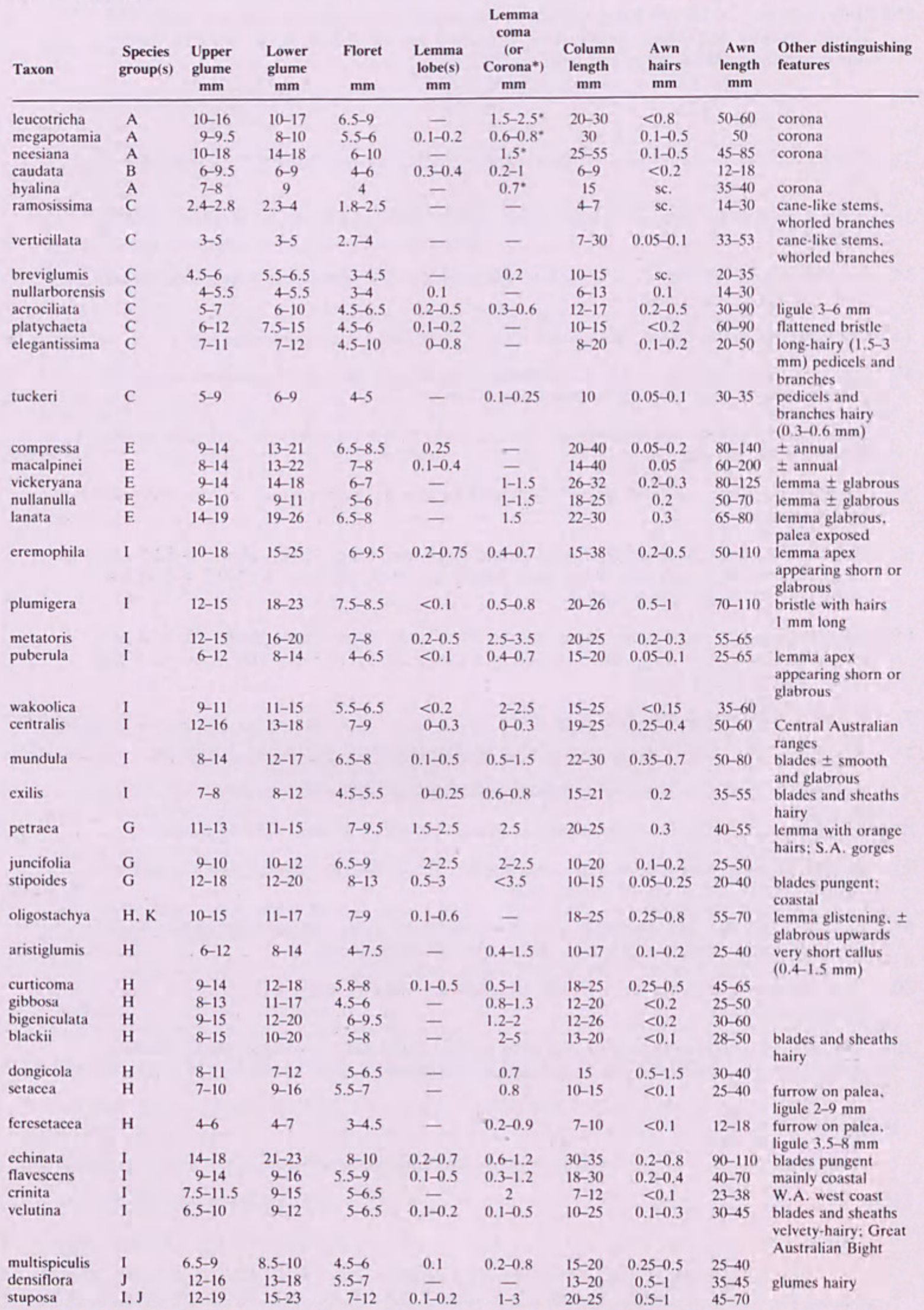




\begin{tabular}{|c|c|c|c|c|c|c|c|c|c|c|}
\hline Taxon & $\begin{array}{l}\text { Species } \\
\text { group(s) }\end{array}$ & $\begin{array}{l}\text { Upper } \\
\text { glume } \\
\text { mm }\end{array}$ & $\begin{array}{c}\text { Lower } \\
\text { glume } \\
\mathrm{mm}\end{array}$ & $\begin{array}{c}\text { Floret } \\
\text { mm }\end{array}$ & $\begin{array}{c}\text { Lemma } \\
\text { lobe(s) } \\
\mathrm{mm}\end{array}$ & $\begin{array}{c}\text { Lemma } \\
\text { coma } \\
\text { (or } \\
\text { Corona*) } \\
\text { mm }\end{array}$ & $\begin{array}{c}\text { Column } \\
\text { length } \\
\mathbf{m m}\end{array}$ & $\begin{array}{c}\text { Awn } \\
\text { hairs } \\
\text { mm }\end{array}$ & $\begin{array}{c}\text { Awn } \\
\text { length } \\
\mathrm{mm}\end{array}$ & $\begin{array}{l}\text { Other distinguishing } \\
\text { features }\end{array}$ \\
\hline mollis & $\mathbf{J}$ & $15-20$ & $16-20$ & $7.5-9$ & - & - & $20-35$ & $0.6-2$ & $60-100$ & \multirow{13}{*}{$\begin{array}{l}\text { column hairs in a } \\
\text { spiral } \\
\text { column hairs in a } \\
\text { spiral } \\
\text { column hairs in a } \\
\text { spiral; Central } \\
\text { Australian ranges } \\
\text { blades and sheaths } \\
\text { scabrous } \\
\text { blades and sheaths } \\
\text { pubescent to hirsute } \\
\text { scrambler. few- } \\
\text { flowered } \\
\text { inflorescence } \\
\text { alpine and subalpine } \\
\text { areas } \\
\text { blades deciduous } \\
\text { palea full-length, } \\
\text { acute } \\
\text { palea short, obtuse } \\
\text { Iemma apex } \\
\text { tuberculate above } \\
\text { lemma apex } \\
\text { tuberculate above } \\
\text { lemma apex } \\
\text { tuberculate above }\end{array}$} \\
\hline hemipogon & J & $10-16$ & $15-20$ & $5-7.5$ & - & - & $10-20$ & $0.5-4$ & $30-60$ & \\
\hline aquarii & J & $9-10$ & $10-12$ & $3.5-5$ & - & - & $10-15$ & $0.8-1.3$ & $40-50$ & \\
\hline semibarbata & J & $15-25$ & $18-27$ & $9-11.5$ & - & - & $30-40$ & $0.3-1$ & $70-110$ & \\
\hline campylachne & J & $14-18$ & $15-23$ & $8-9$ & - & - & 30 & $0.3-1.6$ & $50-70$ & \\
\hline muelleri & G. K & $15-30$ & $18-30$ & $13-20$ & 3 & - & $40-55$ & $0.02-0.2$ & $50-100$ & \\
\hline nivicola & K & $15-20$ & $20-25$ & $12-15$ & - & - & $55-70$ & $0.05-0.5$ & $85-130$ & \\
\hline aphylla & K & 14 & 16 & $8.5-10$ & 0.5 & $0.4-0.8$ & $35-$ & $0.1-0.25$ & $60-85$ & \\
\hline pubinodis & $\mathrm{K}$ & $15-20$ & $18-29$ & $10-13$ & & & $30-60$ & $0.1-0.2$ & $55-95$ & \\
\hline $\begin{array}{l}\text { pubescens } \\
\text { rudis }\end{array}$ & $\begin{array}{l}\mathrm{K} \\
\mathrm{K}\end{array}$ & $15-20$ & $17-24$ & $9.5-15$ & - & - & $45-70$ & $0.05-0.15$ & $60-100$ & \\
\hline ssp. rudis & & $9-12.5$ & $10-15$ & $7.2-10$ & $0.05-0.25$ & - & $20-25$ & $0.05-0.3$ & $35-65$ & \\
\hline ssp. nervosa & & $7-10$ & $8-12$ & $5-8.5$ & $0.05-0.25$ & $<1$ & $8-20$ & $0.05-0.3$ & $20-45$ & \\
\hline ssp. australis & & $11-14.5$ & $12-15$ & $8.6-11.5$ & - & - & $32-45$ & $0.05-0.3$ & $60-90$ & \\
\hline
\end{tabular}

Part 2: Species with falcate awns

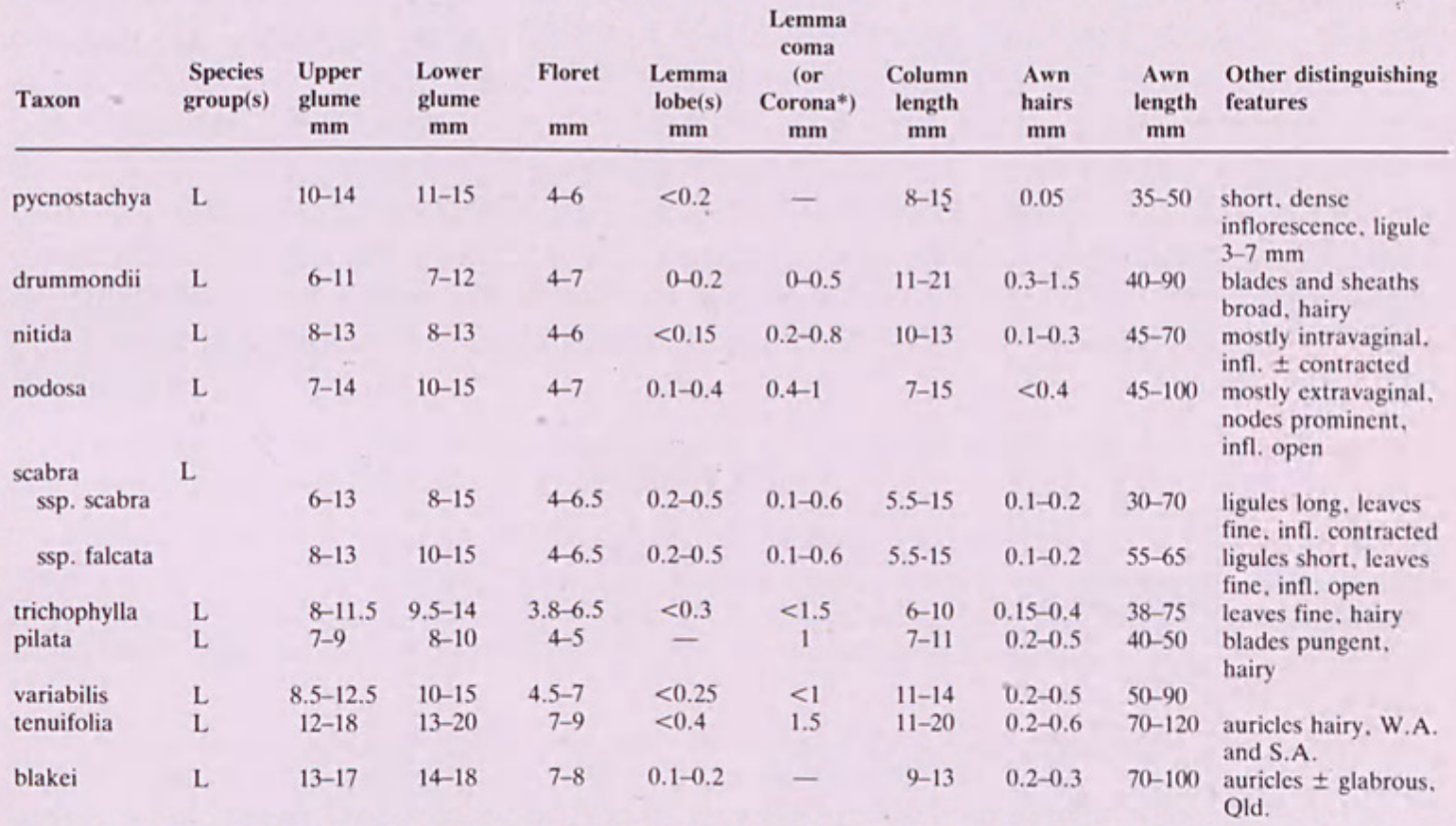


Stipa acrociliata Reader, Victorian Naturalist 13: 167 (1897), ibid. 15: 145 (1899); Hughes, Kew Bull. 1921: 28 (1921), ibid. 1922: 19 (1922); Black, Fl. S. Austral. 1: 65 (1922), edn 2: 91 (1943); Ewart, Fl. Victoria: 182 (1931); Gardner, Fl. W. Austral. 1, Gram.: 178 (1952); Vickery, Contrib. N.S.W. Natl. Herb. 2: 78 (1953); Willis, Handb. Pl. Victoria 1: 183 (1962), edn 2: 183 (1970).

Holotype: Victoria: Sandy desert, Lowan Shire, F. Reader, 1895 (MEL 59867!; apparent isotypes MEL 59869 with panicle, 59868 foliage only).

SyNONYM: $S$. readeri F. Muell. ex Reader, Victorian Naturalist 13: 168 (1897), in syn.

Shortly rhizomatous or caespitose perennial to 1.5 metres high, often with several branches at the nodes, with or without a basal tuft of leaves to about one third the height. Culms erect or slightly geniculate at the base, to $3 \mathrm{~mm}$ wide, scarcely compressible, moderately to strongly ribbed, glabrous or just below the nodes very shortly puberulous; nodes $2-3$, exserted, glabrous, to $50 \%$ wider than adjacent internodes. Leaf sheaths usually inflated, to $10 \mathrm{~mm}$ wide, strongly to moderately ribbed, glabrous to scaberulous with minute stiff hairs or pubescent; margins glabrous. Ligule truncate, obtuse, or laciniate, membranous, 2.5-6 mm long, glabrous; auricles thickened, 1-2 mm long, glabrous. Leaf blade expanded or loosely inrolled, 3-10 $\mathrm{mm}$ wide, to $40 \mathrm{~cm}$ long; abaxial surface strongly ribbed, glabrous to scaberulous with minute stiff hairs; adaxial surface strongly ribbed, glabrous to scaberulous with minute stiff hairs; margins glabrous. Panicle to $50 \mathrm{~cm}$ long, expanded, 4-12 cm wide (excluding awns), exserted, with distant fascicles of unequal few-flowered branches; branches $4.5-10 \mathrm{~cm}$ long, slightly angular, scabrous along the edges; pedicels $1-10 \mathrm{~mm}$ long, angular, minutely scabrous along the edges. Spikelets $6-10 \mathrm{~mm}$ long (excluding awn), gaping. Glumes unequal, green, straw-coloured or purplish, scabrous on the nerves; lower glume $6-10 \mathrm{~mm}$ long, acuminate to acute, often ciliate at the tip, lower $40-50 \%$-nerved; upper glume $5-7 \mathrm{~mm}$ long, obtuse to broadly acute, usually ciliate at the tip, the lower 30-50\% 5-nerved, the next $20-40 \%$ 3-nerved. Floret elliptical, with no definite neck, 4.5-5.5 (-6.5) mm long (including callus). Lemma surface brown and finely tuberculate with erect, spreading white hairs up to the apex; lobes 2, 0.2-0.5 mm long, or absent; coma obscure, $0.3-0.6 \mathrm{~mm}$ long. Callus $1.0-1.5 \mathrm{~mm}$ long, fine and straight, the tip sharp. Awn 3-7 (-9) cm long with 1-2 slight bend(s), $0.1-0.2 \mathrm{~mm}$ wide near the base; column $12-17 \mathrm{~mm}$ long, 6-10 $\mathrm{mm}$ to the first bend, pubescent with hairs $0.2-0.5 \mathrm{~mm}$ long; bristle occasionally slightly curved, scaberulous, often darker than the column. Palea equal in length to the lemma, acute, densely pubescent down the centre, glabrous on the margin; apex ciliate. Lodicules 2, abaxial, membranous, $1-1.7 \mathrm{~mm}$ long, obtuse. Anthers $1.5-1.8 \mathrm{~mm}$ long, not or minutely penicillate. Caryopsis 3-3.5 mm long; embryo $20-25 \%$ the length; hilum $60-65 \%$ the length.

Distribution: Sandy areas of the western plains of New South Wales and Victoria; arid areas of South Australia and on limestone of the Nullarbor Plain.

Selected Specimens: New South Wales: North Western Plains: West Bogan-Nyngan, Butchee NSW 116147, 26.11.1934 (NSW). South Far Western Plains: $7 \mathrm{~km} \mathrm{~N}$. of highway on Arumpo road E. of Euston, Cunningham 4022 \& Milthorpe, 13.10 .1975 (NSW); 60 miles [96 km] N. of Balranald, Leigh NSW 116146, 20.10.1964 (NSW); 20 km W. of Balranald, Mulham NSW 116674, 11.1974 (NSW).

Victoria: Region A: Red Cliffs, Henshall, 16.3 .1969 (NT 43331). Region B: Timberoo Forest Reserve, 10 miles [16 km] SW. of Ouyen, Beauglehole 40396, 19.9.1972 (NSW, MEL); 4 miles [6 km] N. of Tempy, Henshall NSW 116675, 20.9.1969 (NSW); Wyperfeld National Park, W. of Moorong Rise, Beauglehole 29519 \& Finck, 12.11 .1968 (NSW, MEL). Region C: Little Desert, Reader 18.11.1896 (MEL 59871, AD); Lowanshire, no collector, 1895 (MEL 59874). Region F: 
Annuello, c. 23 km NNW. of Manangatang, Beauglehole 55841, 29.4.1977 (MEL). Region G: 5 km SW. of Chinkapook, c. $18 \mathrm{~km} \mathrm{~S}$. of Manangatang, Beauglehole 55495, 17.4.1977 (MEL); $5 \mathrm{~km} \mathrm{W.} \mathrm{of}$ Gama, Beauglehole 56907, 22.10.1977 (MEL, NSW).

SOUTH AUSTRALIA: Nullarbor: 3 miles [5 km] inland from the cliff tops at 'Koonalda' Station, Symon 4589, 17.2.1967 (ADW, CANB); 9 km W. of Yalata, Beauglehole 49510, 31.8.1974 (CANB); WA/SA border on Eyre Highway, Phillips CBG 005337, 8.9.1962 (CBG). Eyre Peninsula: 'Colona' Homestead, Willis, 27.2.1947 (MEL 60866); c. $15 \mathrm{~km} \mathrm{~W}$. of Nundroo, Spooner 2189, 1.9.1972 (AD); Bookabie Mallee, Hilton, 21.8.1955 (ADW 19784, 20593); Wirrulla to Penong Road, Cleland, 17.9.1957 (AD); Ceduna, Canning CBG 039220, 1.9 .1968 (CBG, NSW); 8 miles [13 km] from Streaky Bay towards Ceduna, Phillips NSW 116144, 30.8.1968 (CBG, NSW); 63 miles [100 km] from Port Lincoln towards Whyalla, Phillips CBG 054383, 3.9.1962 (CBG); $40 \mathrm{~km}$ NW. of Kimba, Rohrlach 685, 18.10.1959 (AD); 12 miles [19 km] E. of Kimba, Cleland, 14.10.1953 (AD); Mangaloo area, Turner NSW 116150, 12.1954 (NSW, ADW); between Lock and Cleve, French, 9.1954 (ADW 28158); Hambridge Reserve, NW. \& NNW. from Prominent Hill, Symon 4180, 8.10.1966 (ADW); Verran Hill, Hincks National Park, Alcock 2176, 6.10 .1968 (AD); Yeelanna, 10 miles [16 km] N. of Cummins, Hilton, 20.12.1945 (ADW 43830); Boston I. near Port Lincoln, Wilson 303, 8.10 .1958 (AD). Northern Lofty: Halbury, Cleland, 31.8 .1963 (AD); Owen, c. $35 \mathrm{~km}$ E. of Port Wakefield, Cleland, 16.11.1955 (AD). Murray: Waikerie, Cleland, 29.8.1946 (AD); c. $13 \mathrm{~km}$ SW. of Waikerie, Crisp 630, 7.10.1973 (CBG); Monarto City Centre, Symon 9751, 3.12.1974 (NSW, ADW); Karoonda (Trans-Murray Scrub), Black, 12.11.1915 (MEL 60928); Naturi near Victorian border, Black, 15.10.1925 (AD). Yorke Peninsula: 10 miles [16 km] from Edithburgh towards Moorowie Point, Phillips 1247, 3.10.1965 (CBG). Southern Lofty: between Reeves Plains \& Kangaroo Flat, Harris 33, 1.10.1959 (AD); Roseworthy Agricultural College, Symon, 1946 (ADW 25095); Hindmarsh I., Goolwa, Hilton, 10.10.1945 (ADW 43829); Hundred of Wiltunga, Copley 276, 12.5.1966 (NSW). South-eastern: 10 miles [16 km] E. of Mannum, Blake 16843, 24.8.1946 (BRI); near Goolwa, 11 miles [17 km] ENE. of Victor Harbour, Hilton, 23.11.1935 (ADW 43828); Cape Jervis, Carroll 1386, 6.10.1965 (CBG); 4 miles [6 km] E. of Tintinara, 63 miles [100 km] SE. of Tailem Bend, Hilton (ADW 44075); Tintinara, Phillips CBG 037668, 21.10.1966 (CBG, AD).

Western Australia: Eucla: c. 5 km E. of Eucla Pass, Parsons 30, 26.11.1967 (AD); Mundrabilla Station, Aplin 1701, 2.9.1962 (PERTH); Eyre Highway, 8 miles [13 km] W. of Madura Pass, George $10573,16.10 .1966$ (PERTH); $46 \mathrm{~km}$ WSW. of Madura, Beauglehole 49402, 30.8.1974 (CANB); 27 $\mathrm{km}$ W. of Madura Hotel, Eyre Highway, Chinnock 1176, 20.9.1973 (AD); Twilight Cove, Great Australian Bight, George 8568, 16.10.1966 (PERTH). Coolgardie: Westonia, Moffat, 10.1924 (PERTH); 14 miles [22 km] N. of Norseman on Coolgardie road, Beauglehole 11343, 21.9.1965 (CANB, PERTH); $7 \mathrm{~km}$ NNE. of Norseman, Crisp 5950, 19.7 .1979 (CBG); c. $160 \mathrm{~km} \mathrm{E.} \mathrm{of}$ Balladonia, Jackson 1469, 24.10.1968 (PERTH); 32 miles [51 km] E. of Balladonia, Main, 29.8.1955 (PERTH). Darling: Perth district, per Dept. Agric. W.A., NSW 116149, 10.1907 (NSW). Eyre: 1.5 $\mathrm{km} \mathrm{N}$. of Baanga Hill, Saffrey 448, 11.8.1968 (PERTH); Israelite Bay, Jackson 1306, 1.10.1968 (PERTH); Lovers Cove, Esperance, Cleland, 11.10.1950 (AD); East Barren Range, 4 miles [6 km] W. of Hopetoun, Beauglehole 13343, 21.9.1965 (CANB; PERTH); between Esperance Bay \& Frasers Range, Dempster, 1876 (MEL 60927); Fitzgerald River National Park, George 10573, 19.12.1970 (PERTH).

Stipa aphylla (Rodway) Townrow, Pap. \& Proc. Roy. Soc. Tasmania 104: 85, 96 (1970), ibid. 112: 232, 235 (1978). Based on S. pubescens var. aphylla Rodway, Tasmanian Fl.: 262 (1903).

TYPIFICATION: Rodway cites 'Dry hills in Southern Tasmania' without specifying a particular locality. Townrow (on p. 96) provides an amended description in Latin and English and singles out a 'Syntype': 'Huon Road (Hobart), Rodway, November 1897, Sheet No. 995, Rodway Collection' (HO, not seen) which we here designate as Lectotype, as doubtless was intended by Townrow.

Caespitose perennial to $0.5-0.6$ metres high, shortly rhizomatous without a basal tuft of leaves. Culms erect, 1-2 mm wide near the base, not compressible, very slightly to moderately ribbed, scabrous with minute tubercles; nodes 3-4, exserted, sericeous with hairs $0.2-0.4 \mathrm{~mm}$ long, c. $25 \%$ wider than the adjacent internodes. Leaf sheath margins glabrous; basal sheath tightly enveloping the culm, 4-8 mm wide, moderately ribbed, scabrous with minute tubercles, sometimes also with hairs; upper sheath slightly inflated, $3.5-4 \mathrm{~mm}$ wide, 
strongly ribbed, glabrous. Ligule membranous, $0.25-0.4 \mathrm{~mm}$ long, with 2-3 obtuse lobes, glabrous; auricles absent. Leaf blade linear, stiff, loosely rolled, c. $1.5 \mathrm{~mm}$ wide, $2-3.5 \mathrm{~cm}$ long, withering before flowering; abaxial surface glabrous to scabrous with minute tubercles, weakly to strongly ribbed; adaxial surface pubescent with hairs $0.1-0.3 \mathrm{~mm}$ long, strongly ribbed. Panicle sparse, c. $11(-25) \mathrm{cm}$ long, exserted, with distant fascicles of unequal, few-flowered, compound branches, c. $2 \mathrm{~cm}$ wide (excluding awns); axis terete, scabrous with minute hairs and tubercles; branches c. $6 \mathrm{~cm}$ long, slightly angled, scabrous with hairs $0.05 \mathrm{~mm}$ long; pedicels $0.5-1.5 \mathrm{~cm}$ long, angled, scabrous with hairs $0.1-0.5(-1) \mathrm{mm}$ long. Spikelets $16 \mathrm{~mm}$ long, gaping. Glumes subequal, acute to acuminate, hyaline with chlorenchyma bands associated with the nerves; lower glume $16 \mathrm{~mm}$ long, scabrous with hairs $0.05(-1) \mathrm{mm}$ long, lower $25 \% 3$-nerved; upper glume c. $14 \mathrm{~mm}$ long, scabrous with hairs c. $0.05 \mathrm{~mm}$ long, lower $50 \% 5$ nerved, upper 50\% 4-1-nerved. Floret cylindrical, without a neck, 8.5-10 mm long. Lemma surface scabrous, sericeous with hairs $0.3-0.6 \mathrm{~mm}$ long; coma $0.4-0.8 \mathrm{~mm}$ long; lobes c. $0.5 \mathrm{~mm}$ long or absent. Callus (1.5-) $2 \mathrm{~mm}$ long, weakly bent at the tip, sericeous with dense white hairs $0.2-1 \mathrm{~mm}$ long, tip glabrous. Awn $6-8.5 \mathrm{~cm}$ long, twice bent, $0.25-0.4 \mathrm{~mm}$ wide near the base; column $3.5-5 \mathrm{~cm}$ long, $2.5-3.5 \mathrm{~cm}$ to the first bend, straw-coloured, pubescent with hairs $0.1-0.25 \mathrm{~mm}$ long; bristle straw-coloured, scabrous with hairs $0.05-0.15 \mathrm{~mm}$ long. Palea sub-equal to the lemma, obtuse or often erose, surface smooth, sericeous along the centre back with hairs c. $0.5 \mathrm{~mm}$ long, margins glabrous. Lodicules $3 ; 2$ abaxial, 1-1.5 mm long, obtuse, brown, brittle; paleal c. $1 \mathrm{~mm}$ long, acute, white. Anthers $3.5-5 \mathrm{~mm}$ long, penicillate. Caryopsis not seen.

\section{DisTRIBUTION: South-eastern Tasmania.}

Selected SPECimens: TASmania: 2 miles [3 km] N. of Bicheno, Townrow, 13.1.1965 (MEL 58875); Copping, Blake 18277, 15.1.1949 (BRI, NSW); near Hobart, common on dry hills, Rodway, 2.1894 (MEL); University of Tasmania, Hobart, Townrow 77, 29.11.1967 (JEST); Ferntree, Lower Pipe track, Townrow 7.3.1965 (JEST); Kingston, Rodway NSW 1i6237 1.1893 (NSW); Huonville, Martin, n.d. (CANB 13186); Barnes Bay, Bruny Is, Townrow 147, 1.2.1968 (JEST); S. Tasmania, Rodway, 1894 (MEL 60850).

S. aphylla is superficially similar to $S$. muelleri, especially because of the reduction and deciduous nature of the leaf blades, but $S$. aphylla differs markedly in that the margins of the lemma are not or scarcely continued as distinct membranous lobes and the lemma has a minute crown of hairs. Hence $S$. aphylla does not belong to the group Aphyllae of Hughes, which was described before the name $S$. aphylla was published.

Stipa aquarii J. Vickery, S.W.L. Jacobs \& J. Everett, sp. nov.

S. hemipogoni affinis sed spicula minore, lemmate anguste fusiformi, arista gracili, differt.

HOLOTYPE: NORTHERN TERrTTORY: Waterhouse Range, $24^{\circ} 02^{\prime} \mathrm{S}, 133^{\circ} 36^{\prime} \mathrm{E}$, P.K. Latz 6349,3 February 1976. Erect perennial. Rare in skeletal soil, walls of gully, sandstone hill (NT).

Caespitose perennial to c. 1 metre high, with basal shoots to three quarters the height, and very short rhizomes. Culms c. $1.5 \mathrm{~mm}$ wide near the base, not easily compressed, terete, finely ribbed, glabrous, finely scabrous to densely pubescent $1 \mathrm{~cm}$ below the nodes; nodes 5-6, c. $40 \%$ broader than adjacent internodes, shortly retrorsely sericeous, scarcely or only the uppermost exserted. 
Leaf sheaths c. $2 \mathrm{~mm}$ wide, scabrous to sparsely hirsute and scabrous on the basal sheaths; outer margin sparsely ciliate to glabrous; inner margin glabrous. Ligule obtuse, coriaceous, 1-2 mm long, $0.5 \mathrm{~mm}$ long on basal leaves, densely long-ciliate, sericeous on the abaxial surface; auricles slightly thickened, tufted with sparse straight hairs. Leaf blades loosely rolled, to $60 \mathrm{~cm}$ long, 1-2 mm wide; abaxial surface scabrous with dense, short, antrorsely hooked tubercles; adaxial surface long-pubescent, ribbed. Panicle dense, contracted, with closely spaced fascicles of unequal compound branches, exserted, c. 14-20 cm long, $1 \mathrm{~cm}$ wide (excluding awns); axis terete, finely scaberulous; branches slightly flattened, to $3 \mathrm{~cm}$ long, scaberulous; pedicels slightly flattened, $1-4 \mathrm{~mm}$ long, scaberulous. Spikelets scarcely gaping, 10-12 mm long (excluding awn). Glumes subequal, acuminate, transparent, glabrous except for a scaberulous midrib; lower glume 10-12 mm long, lower 30\% 3-nerved; upper glume 9-10 mm long, lower 20\% 3-nerved. Floret 3.5-5 mm long (including callus), narrowly fusiform, brown at maturity, the midrib pale. Lemma with sparse spreading yellow hairs, sparser upwards, the upper $1 \mathrm{~mm}$ glabrous; surface granular and with antrorsely hooked tubercles on the upper half; coma absent; lobes absent. Callus short and curved, c. $1 \mathrm{~mm}$ long, sericeous with yellowish hairs. Awn $40-50 \mathrm{~mm}$ long, $0.2 \mathrm{~mm}$ wide near the base, pale brown, twice bent; column 10-15 mm long, $7-9 \mathrm{~mm}$ to the first bend, villous with hairs $0.8-1.3 \mathrm{~mm}$ long, continuing halfway along the bristle, the remaining half of the bristle scaberulous. Palea acute, shorter than the lemma by $0.5 \mathrm{~mm}$, coriaceous, granular and sparsely hairy to glabrous down the midline. Lodicules 2, spathulate, membranous, $0.7 \mathrm{~mm}$ long. Anthers $0.8 \mathrm{~mm}$ long (chasmogamous), cilia not observed. Caryopsis 2-2.5 mm long; embryo $25-30 \%$ the length.

Distribution: Central Australian Ranges, on hillsides.

SPECIMENS EXAMINED: NORTHERn TERritory: Central Australia: Gosses Bluff, $23^{\circ} 49^{\prime} \mathrm{S}, 132^{\circ} 18^{\prime} \mathrm{E}$, Latz 9035, 11.4.1982 (NSW); Waterhouse Range, $24^{\circ} 02^{\prime} \mathrm{S}, 133^{\circ} 36^{\prime} \mathrm{E}$, Latz 6349, 3.2.1976 (NT, NSW, CANB); $13 \mathrm{~km}$ NE. Kings Canyon, $24^{\circ} 13^{\prime} \mathrm{S}, 131^{\circ} 41^{\prime} \mathrm{E}$, Latz 8853, 21.7.1981 (NT).

The specific epithet is from the Latin "of the water man", having a similar derivation to the surname 'Waterhouse', after which the Range in which the Type was collected was named.

The ms. name "S. aquavilla" appears on some of our early determinavit slips on specimens of this species.

Similar to $S$. hemipogon but differing in the smaller spikelet with narrowfusiform lemma (turbinate in $S$. hemipogon) and slender awn.

Stipa aristiglumis F. Muell., Trans. \& Proc. Victorian Inst. Advancem. Sci.: 43 (1855), Fragm. Phytogr. Austral. 8: 103 (1873); Bentham, Fl. Austral. 7: 570 (1878); Bailey, Syn. Queensland Fl.: 650 (1883); Moore \& Betche, Handb. Fl. N.S.W.: 484 (1893); Hughes, Kew Bull. 1921: 25 (1921), ibid. 1922: 19 (1922); Willis, Handb. Pl. Victoria 1: 185 (1962), edn 2: 185 (1970).

HolotYPE: Victoria: cited as 'In bushy parts of the Murray Desert. F. Mueller'. Two sheets at MEL (MEL 59879! and (vegetative only) MEL 59878!) marked respectively 'Murray' and 'Ad flumen Murray' by Mueller appear jointly to be the Holotype. As Hughes (1922) notes, the glumes on MEL 59879 are torn between the nerves so that the nerves project as teeth. 
SYNONYM: S. fusiformis Hughes, Kew Bull. 1921: 25 (1921). See also Hughes, Kew Bull. 1922: 19 (1922). Holotype: Victoria: Murray River, Mueller 19277 (K). Hughes also cited the following specimens: New South Wales: Cassilis, Leichhardt (K) (not seen definitely); VictoriA: Avoca River, F. Mueller (K) (NSW 116069 from Herb. Hooker is probably a duplicate).

Caespitose perennial to 2 metres high with a sparse basal tuft c. one third the height. Culms erect or slightly geniculate near the base, terete, not compressible, c. (1.5-) $2.5(-5) \mathrm{mm}$ wide near the base, ribbed, glabrous to puberulous. Nodes 3, exserted, $35-45 \%$ broader than adjacent internodes, pubescent with slightly spreading short hairs or occasionally glabrous. Leaf sheaths at first tightly enveloping the culms, soon becoming loose, 3-6 mm wide, ribbed, glabrous or between the ribs scaberulous; inner margin glabrous; outer margin long-ciliate, or the basal part glabrous. Ligule thinly coriaceous to chartaceous, scarcely ciliate, glabrous except for a small tuft of hairs each side, truncate to obliquely truncate, $0.8-1.5 \mathrm{~mm}$ long or obtuse and to $3 \mathrm{~mm}$ long when continuous with one or both sheath margins; auricles thickened, glabrous. Leaf blades flat or convolute (most tightly in leaves of the basal tuft), to $40 \mathrm{~cm}$ long, 3-6 mm wide; abaxial surface scabrous with minute hairs or glabrous, occasionally with widely scattered strong or weak hairs, especially on the basal leaves; adaxial surface minutely scaberulous, occasionally with scattered weak hairs; margins similar to adjacent surface or with sparse long strong hairs. Panicle to $40(-55) \mathrm{cm}$ long, exserted at length, moderately sparse with distant fascicles of many, unequal, few-flowered compound branches, usually spreading, (2-) 6-10 cm wide (excluding awns); axis terete and glabrous at the base, upwards flattened and scabrous with dense minute hairs mostly on the edges; branches to $20 \mathrm{~cm}$ long, flattened, scabrous with minute hairs mostly on the edges; pedicels to $12 \mathrm{~mm}$ long, flattened, scabrous, with minute hairs mostly on the edges. Spikelets 8-14 mm long (excluding awn), gaping widely at floret disarticulation, otherwise tightly closed. Glumes unequal, firm and green for most of the length, the tip membranous and transparent between the nerves and often eroded, acuminate with long fine tips often reduced to the midrib, moderately broad and inflated at the middle, glabrous or the nerves scabrous, or scabrous with dense minute hairs overall; chlorenchyma bands associated with the nerves; lower glume 8-14 mm long, lower 75-90\% 3-nerved; upper glume 6-12 mm long, lower $60-50 \%$ 5-nerved, 3-nerved up to $90 \%$ of the length. Floret (4-) 5-7.5 mm long (including callus), fusiform, tapering gradually to the base of the awn. Lemma gold-brown to dark red-brown at maturity, sericeous with appressed white to yellow hairs becoming gold at late maturity and sparse to absent at the apex, central nerve thickened; lobes minute or absent; coma of very sparse, appressed hairs of varying lengths to $0.4-1.5 \mathrm{~mm}$ long, or occasionally absent. Callus short and broad, 0.4-1 (-1.5) $\mathrm{mm}$ long, scarcely differentiated from the lemma, with hairs similar to those of the lemma, the naked point very short, $0.1-0.15(-0.2) \mathrm{mm}$ long, and rounded. Awn $25-40 \mathrm{~mm}$ long, twice bent, $0.2(-0.3) \mathrm{mm}$ wide near the base; column 10-17 mm long, 4-9 $\mathrm{mm}$ to the first bend, scabrous with sparse appressed hairs less than 0.1 $(-0.2) \mathrm{mm}$ long; bristle scaberulous. Palea \pm equal to the lemma, coriaceous, slightly thinner at the margins, granular down the centre, acuminate, glabrous or with a few hairs down the centre. Lodicules 3, membranous; 2 abaxial 1.1-1.8 mm long, broadly cuneate; paleal $0.5-1.2 \mathrm{~mm}$ long, oblong. Anthers 2-3 mm long, usually penicillate. Caryopsis 3-4.5 mm long; embryo $30-50 \%$ the length; hilum $75-90 \%$ the length.

DisTRIBUtion: On heavy soils west of the Great Dividing Range from southern Queensland to Victoria. 
Selected Specimens: QueEnsland: Darling Downs: Jondaryan, Blake 7740, 22.2.1935 (NSW); Oakey, Donges, 1930 (BRI); nr. Kingsthorpe, Blake 13248, 12.2.1938 (NSW); Toowoomba, Pollock, 9.12.1938 (BRI); Pitsworth, Roe, 5.12.1938 (BRI); Cambooya, White 12679, 19.10.1944 (BRI); Tummaville, White 12586, 19.11.1944 (BRI); Clifton, White, 12.1912 (BRI); Talgai, Bailey (BRI); between Toowoomba \& Warwick, White 13099, 6.3.1944 (BRI); Allora, Bailey (BRI). Moreton: Brisbane River, Bailey 57, 3.1873 (MEL).

New South WaLES: North Coast: Singleton, Boorman NSW 116067, 11.1914 (NSW). Central Coast: Hawkesbury River, Cleland, 4.1912 (AD 98100091). Northern Tablelands: New England, McFarland, 1890 (MEL); between Tamworth \& Glen Innes, White 10412, 29.12.1935 (BRI). Central Tablelands: Bathurst Experiment Farm, May, 26.3 .1941 (NSW). North Western Slopes: Wallangra, Rodway NSW 116083, 28.9.1929 (NSW); Warialda, Vickery NSW 116087, 1.1932 (NSW); Gravesend, Breakwell NSW 116088, 16.1.1913 (NSW); Glendon nr. Gravesend, Carne NSW 116089, 5.1914 (NSW); 3 miles [5 km] N. of Stannifer on Elsmore road, Jessup \& Gray 2794, 10.3.1954 (CANB); "Derra Derra", 16 miles [26 km] W. of Bingara, Hindwood NSW 116092, 7.10.1950 (NSW); Barraba, Rupp NSW 116093, 26.2.1914 (NSW); Boggabri, Cambage NSW 116094, 11.1909 (NSW); Gunnedah, Gardiner NSW 116095, 29.11.1939 (NSW); Piallaway district, between Currabubula \& Carroll, Goode 95, 8.11.1954 (NSW); Tamworth, McKie NSW 116096, 15.4.1947 (NSW); nr. Tamworth, Phillips \& Vickery CBG 001275, 21.2.1961 (AD, CANB); Liverpool Plains, NSW 116098, 2.1850 (NSW); Quirindi, Rowntree NSW 116100, 11.1917 (N.S.W.); c. 3 miles [5 km] N. of Wallabadah, Goode NSW 116I03, 11.11 .1954 (NSW); nr. Bundella, (c. 41 miles [65.5 km] WSW. of Quirindi), Pickard \& Coveny 1172, 6.6.1969 (NSW). Central Western Slopes: Scott Creek near Blandford, Reiner 292, 21.1.1960 (CANB); "Belltrees" via Scone, White NSW 116053, 2.1920 (NSW); Cassilis, Leichhardt, (MEL); Yangambil Plains, Trangie, Hutchings 59, 22.10.1948 (CANB); 1 mile $[1.6 \mathrm{~km}] \mathrm{E}$. of Bunnan (16 miles [26 km] W. of Scone), Story 6947, 27.11.1959 (CANB, BRI); Scone Experimental Station, Story 7059, 15.3 .1960 (AD, CANB, PERTH); Bow, 7 miles [11 km] W. of Merriwa, Story 6989, 1.12.1959 (CANB); Narromine, Helms NSW 116054, 12.1892 (NSW); Eulomogo, Blakely NSW 116056, 10.1912 (NSW); 6 miles $[10 \mathrm{~km}] \mathrm{W}$. of Wellington, Henderson NSW 116050, 31.12.1946 (NSW); Mudgee, Betche NSW 116058, c. 1885 (NSW); Alectown, Bradford NSW 116059, 25.11.1949 (NSW); 13 km E. of Condobolin, Cunningham \& Milthorpe 1546, 19.11.1973 (NSW); Bedgerebong, Henderson NSW 116049, 31.12.1946 (NSW); Forbes, Cashmore, 2.3.1935 (ADW 250); 'Allandale', Cowra road, Forbes, Tretheway NSW 116060, 23.11.1942 (NSW); between Grenfell \& Forbes, Martensz 4128, 8.12.1968 (CANB); Marsden, Hill NSW 116062, 6.11.1962 (NSW); West Wyalong, Ballantine NSW 116063, 6.3.1939 (NSW). South Western Slopes: between Wagga \& Lockhart (19 miles [30 km] from Lockhart), Moore 1081, 21.11.1948 (CANB); Burrumbuttock-Howlong Road, McBarron 4371 (in part), 3.8.1950 (NSW). North Western Plains: Moree to Bullarah, Waterhouse NSW 116075, 4.11.1956 (NSW); Narrabri, Vickery NSW 116077, 10.12.1928 (NSW); Condobolin, Cunningham \& Milthorpe NSW 117006, 6.3.1978 (NSW). South Western Plains: Euabalong, Doyle NSW 116080, 11.1963 (NSW); Deniliquin, Leigh NSW 116081, 25.10.1963 (NSW); between Oaklands \& Berrigan (8 miles [13 km] from Berrigan), Moore, 22.11.1948 (CANB 32524).

VICTORIA: Region C: Shire of Dimboola, Reader, 10.2.1895 (MEL); Horsham, Willis \& Beauglehole 7870, 17.10.1960 (NSW); Wimmera, Pye, 1889 (MEL 60659). Region G: nr. Kerang, Baldwin, 11.1937 (MEL, ADW 43834). Region H: Minyip, Eckert, 12.5.1899 (MEL); Avoca River, Hooker NSW 116069, (NSW). Region M: 4 miles [6.4 km] from Rochester, Phillips CBG 046200, 8.11.1965 (CBG); Mooroopna, Black, 12.11.1942 (MEL); Tatura, Gauba CBG 003585, 20.12.1945 (CBG). Region N: 1 mile [1.6 km] south of Laverton, Cullinore 125, 28.11.1967 (CANB, BRI). Region R: Rutherglen, Dreven, 12.1886 (MEL).

Stipa bigeniculata Hughes, Kew Bull. 1922: 20 (1922); Vickery, Contrib. N.S.W. Natl. Herb. 2: 78 (1953).

Holotype: New South Wales: Cooma, R.T. Baker, Jan. 1887 (K!). The sheet at K consists of a drawing made from a specimen in the U.S. National Herbarium (US), No. 993695(!), together with a packet containing a portion of a panicle with attached glumes and florets. NSW I16547 from Cooma, but without indication of collector's name or date, is perhaps part of the Type collection
and matches the Holotype well.

Caespitose perennial to 1 metre high with a basal tuft of leaves to one third the height. Culms erect or geniculate at the base, terete, c. $2 \mathrm{~mm}$ wide near the base, scarcely compressible, not or only slightly ribbed, puberulous at the base, glabrous upwards except just below the nodes; nodes $2-3$, exserted, sericeous, 
$20-50 \%$ wider than adjacent internodes. Leaf sheaths enveloping the culm, 4-5 mm wide, minutely scaberulous but upper sheaths glabrous; cataphylls and very basal sheaths pubescent; outer margin ciliate to long and woolly near the orifice, although upper-sheath margins glabrous. Ligule truncate, coriaceous, $0.3-0.5 \mathrm{~mm}$ long although occasionally the outer sheath-margin extended $1 \mathrm{~mm}$ past the orifice, ciliate, abaxial surface sericeous; auricles usually with tufts of stiff hairs to $1 \mathrm{~mm}$ long. Leaf blade weakly rolled (those of the basal tuft more tightly so), c. $3 \mathrm{~mm}$ wide, to $25 \mathrm{~cm}$ long; abaxial surface slightly ribbed, shortly and strongly scabrous on lower blades, upper blades glabrous; adaxial surface strongly ribbed, densely minutely scaberulous, with occasional longer hairs; margins glabrous or strongly scabrous. Panicle $25-45 \mathrm{~cm}$ long, exserted with distant fascicles of unequal, few-flowered, compound branches, contracted and 2-3 cm wide (excluding awns), or expanded and to $15 \mathrm{~cm}$ wide (excluding awns); axis terete, strongly scabrous; branches flattened or angular, 3-16 cm long, scabrous; pedicels flattened or angular, scabrous, 6-20 mm long. Spikelets $12-18(-20) \mathrm{mm}$ long (excluding awn), gaping widely after floret disarticulation, otherwise tightly closed. Glumes unequal, firm throughout, glabrous or minutely scabrous especially at the tip, usually purple-tinged at the base, white at the tip, broad and inflated at the middle, narrowed abruptly at the tip; chlorenchyma bands associated with the nerves; lower glume $12-18(-20) \mathrm{mm}$ long, lower $75 \%$ 3-nerved; upper glume 9-12 (-15) mm long, the lower 35\% 5-nerved, the next $30 \% 3$-nerved. Floret oblong-cylindrical to oblanceolate-cylindrical, with a welldefined neck, 6-8.5 (-9.5) $\mathrm{mm}$ long (including callus). Lemma reddish brown at maturity, the surface tuberculate, scabrous with antrorse hooks at the apex, the central nerve thickened, usually prominent, with spreading white hairs becoming yellow at maturity; lobes minute; coma (1.2-) $1.4-2.0 \mathrm{~mm}$ long. Callus strong, curved, (1.2-) 1.4-2.5 mm long, sericeous with hairs slightly darker than those of the lemma. Awn 30-60 mm long, strongly twice bent, $0.2-0.35 \mathrm{~mm}$ wide near the base; column 12-22 (-26) mm long, 6-11 $\mathrm{mm}$ to the first bend, scaberulous with hairs less than $0.2 \mathrm{~mm}$ long; bristle scaberulous. Palea \pm equal to the lemma, acuminate, granular down the centre, coriaceous but hyaline on the margins, very sparsely hairy down the centre. Lodicules 3 , membranous; 2 abaxial, 1.3-2.0 mm long, broadly oblong to cuneate; paleal $0.9-1.2 \mathrm{~mm}$ long, narrow-oblong. Anthers $3.0-4.5 \mathrm{~mm}$ long (occasionally $1.5 \mathrm{~mm}$ ), penicillate. Caryopsis 3.5-4.5 mm long; embryo $30 \%$ the length; hilum $90 \%$ the length.

Distribution: Wooded areas of the Central and Southern Tablelands and Slopes of New South Wales, and scattered through Victoria.

Selected Specimens: New South Wales: Central Tablelands: Bathurst district, Ingram NSW 116584, 28.2.1943 (NSW). Southern Tablelands: Crookwell district, Grantham NSW 116560, 3.1.1956 (NSW); Goulburn, Dwyer NSW 116558, 2.1915 (NSW); 18 miles [29 km] SW. of Goulburn, Daniel NSW 116561, 12.1955 (NSW); lower east slopes of Black Mt, Canberra, Pullen 3735, 12.12.1962 (NSW, CANB, MEL, AD); nr. Lake Burley Griffin, Solling 49, 2.2.1972 (NSW); Canberra, Queanbeyan, Cambage NSW 116553, 8.11.1911 (NSW, CANB); Stromlo Forest, Boden CBG 044555, 7.1.1970 (CBG); near Tharwa, Blake 7526, 2.2.1935 (NSW); Bredbo, Murray NSW 116568, 12.1913 (NSW); near Slacks Creek, between Cooma \& Jindabyne, Vickery \& Phillips NSW 116551, 11.1.1956 (NSW); Maffra (Cooma district), Vickery NSW 116557, 14.1.1940 (NSW); 4 miles [6 km] N. of Bombala, Pullen 4466, 21.1.1972 (CANB). Central Western Slopes: Wellington district, Taylor NSW 116571, 11.1956 (NSW); Cowra district, Daniel NSW 116573, 6.3.1950 (NSW). South Western Slopes: Yass district, Grubor NSW 116556, 16.2.1939 (NSW); Gerogery, McBarron 2660 , 24.11.1948 (NSW); Howell Reserve, 4 miles [6 km] W. of Burrumbuttock, McBarron 4735, 3.8.1950 (NSW); Albury, McBarron 1186, 21.10.1947 (NSW). South Western Plains: Binya State Forest, c. 17 km E. of Griffith, Crisp 1638, 20.11.1975 (CBG).

Victoria: Region A: Mildura, Williamson (MEL 60883). Region C: $5 \mathrm{~km} \mathrm{NW.} \mathrm{of} \mathrm{Dimboola,} 36^{\circ}$ 25', 141 ${ }^{\circ}$ 57', Everett 191 \& Jacobs, 30.11 .1980 (NSW). Region H: Inglewood, Sonnenberg, 
13.11.1929 (MEL 60661). Region N: Bacchus Marsh, Meebold 21813, 12.1936 (NSW); Newstead, Black, 18.11.1931 (CANB 9759). Region P: Geelong, Williamson NSW 116572, 7.1905 (NSW). Region R: Barnawartha, Black, 13.11.1939 (CANB 9766).

TASMAnIA: Queens Domain, Curtis (BRI).

Stipa blackii C.E. Hubbard, Kew Bull. 1925: 431 (1925); Black, Fl. S. Austral. edn 2: 92 (1943); Vickery, Contrib. N.S.W. Natl. Herb. 2: 78 (1953); Willis, Handb. Pl. Victoria 1: 185 (1962), edn 2: 185 (1970), perhaps in part.

Holotype: South Australia: Jamestown, J.M. Black 2 (K!; see also CANB photo 237009; isotype AD; probable isotype MEL 59881).

SYNONYMS: $S$. aristiglumis var. cana Reader, Victorian Naturalist 17: 156 (1901). HolOTYPE: Victorla: Sandy Desert, Lowan, F.M. Reader 9.10.1898 (MEL 59880!). Another sheet annotated 'Lowan, F.M. Reader, 9.10.1898' (MEL 69892) is probably a duplicate. The leaves of these specimens are more strongly hairy than in most specimens of $S$. blackii but appear to us to fall within the range of variation of the species.

S. pubescens var. comosa J. Black, Fl. S. Austral. 1: 66 (1922), Trans. \& Proc. Roy. Soc. S. Austral. 46: 565 (1922). TYPIFICATION: Black cites four specimens from South Australia: 'Marino; Jamestown; Melrose; Moolooloo'. All are in Black's herbarium at AD on sheets AD 97424107!, 97424108!, 9724090!, 97424106!, 97422279!, and have been annotated by him as S. pubescens var. comosa and, presumably later, as $S$. blackii C.E. Hubbard or, in the case of the specimen from 'Moolooloo' and one from Jamestown, as $S$. clelandii. The specimen from Jamestown, No. 2 (the type number of $S$. blackii) at AD (AD 97424106) is now devoid of florets except for one lemma partially obscured by adhesive tape, but a probable duplicate of it (though not marked No. 2) in good condition is at MEL (MEL 59881).

S. clelandii Summerhayes \& Hubbard, Kew Bull. 1927: 362 (1927); Black, Fl. S. Austral. edn 2: 92 (1943). Holotype: South Australia: Kinchina, J.B. Cleland S. 40, Nov. 1924, (K, 2 sheets!; see also CANB photo 236996). After repeated examination of a wide range of specimens we are convinced that there is no justification for recognizing $S$. clelandii as a species distinct from S. blackii. As described, $S$. clelandii had a narrow inflorescence (blackii: open), lower glume 18-20 mm (blackii: 12-13 mm), upper glume 11-16 mm (blackii: 8-9 mm), lemma 7-8 mm (blackii: $5.5-6 \mathrm{~mm}$ ) and the awn $50 \mathrm{~mm}$ (blackii: $25-30 \mathrm{~mm}$ ). The respective type specimens undoubtedly display some discrepancies in dimensions but the various individual characters may be found distributed within a population.

Caespitose perennial c. 1 metre high with a basal tuft of leaves c. half the height. Culms erect or geniculate at the base, $1.5-2.5 \mathrm{~mm}$ wide near the base, scarcely compressible, slightly ribbed, densely sericeous to scaberulous or glabrous upwards, hairs longer just below the nodes; nodes c. 3-4, exserted, sericeous, $30-50 \%$ wider than adjacent internodes. Leaf sheaths at first tightly enveloping the culm, later becoming free, $5-6 \mathrm{~mm}$ wide, $2 / 3$ the length of the internodes, densely pubescent, scaberulous and hirsute, upper sheaths pubescent or glabrous; outer margins long-woolly to ciliate on upper-sheath margins. Ligule truncate to shortly laciniate, coriaceous, $0.3-1.5 \mathrm{~mm}$ long, ciliate; abaxial surface sericeous; auricles usually thickened and spreading, pubescent. Leaf blade expanded or weakly rolled (those of the basal tuft more tightly so), $2-5 \mathrm{~mm}$ wide, to $20 \mathrm{~cm}$ long; abaxial surface slightly ribbed, densely pubescent or scabrous with short hairs and sparsely hirsute or scabrous with longer hairs, lower blades more scabrous than upper; adaxial surface ribbed, densely minutely scaberulous; margins similar to abaxial surface or with occasional long, rigid hairs. Panicle $10-30 \mathrm{~cm}$ long, exserted, with distant fascicles of unequal, fewflowered, compound branches, \pm contracted (although spreading at anthesis), 2-6 cm wide (excluding awns); axis slightly angular, moderately to sparsely scabrous; branches $2-8 \mathrm{~cm}$ long, \pm terete or triquetrous, scabrous on the edges; pedicels 5-13 mm long, \pm terete or triquetrous, scabrous on the edges. Spikelets 
10-17 (-19) mm long (excluding awn), gaping after floret disarticulation, otherwise tightly closed. Glumes unequal, acuminate, broad and inflated at the middle, narrowed abruptly at the tip, firm and green at the base, purple-tinged across the centre, hyaline and often torn at the tip, densely minutely scabrous to almost glabrous; chlorenchyma bands associated with the nerves; lower glume 10-17 (-20) mm long, lower $80 \%$ 3-nerved, margins often ciliate; upper glume 8-15 mm long, lower 30\% 4-5-nerved, the next 50\% 3-nerved. Floret turbinate to oblanceolate-cylindrical with a weakly defined neck, 5-7 (-8) $\mathrm{mm}$ long (including callus). Lemma slightly gibbous at maturity, reddish brown, the surface tuberculate, scabrous with antrorse hooks at the apex, the central nerves slightly thickened, with white spreading hairs becoming yellow to orange at maturity; lobes minute; coma 2-3 $(-5) \mathrm{mm}$ long. Callus 1.2-2.3 $\mathrm{mm}$ long, sharp, sturdy and curved, with hairs slightly darker than those of the lemma. Awn 28-40 (-50) $\mathrm{mm}$ long, strongly twice bent, $0.2-0.4 \mathrm{~mm}$ wide near the base; column $13-20 \mathrm{~mm}$ long, $6-10 \mathrm{~mm}$ to the first bend, scaberulous with hairs less than $0.1 \mathrm{~mm}$ long; bristle delicate, often darker than the column, scaberulous. Palea \pm equal to the lemma, broadly acuminate, granular down the centre, coriaceous but hyaline on the margins, very sparsely hairy down the centre or glabrous. Lodicules $3 ; 2$ abaxial membranous, $1.2-2 \mathrm{~mm}$ long, narrow-cuneate to oblong; paleal membranous to slightly coriaceous, narrow-triangular. Anthers 2.5-3.5 mm long, penicillate. Caryopsis $3.4-3.8 \mathrm{~mm}$ long, slightly gibbous above; embryo $50-30 \%$ the length; hilum $90 \%$ the length to \pm equal in length.

Distribution: Widespread on heavier soils in New South Wales, Victoria and South Australia with a few records from Western Australia.

Selected SPECimens: New South WALES: Northern Tablelands: between Brushwood \& Currawarua, Moore 1085, 17.11.1948 (CANB). Southern Tablelands: near Jindabyne, Vickery NSW 116826, 5.1.1956 (NSW). Central Western Slopes: Minore, Blakely NSW 116117, 10.1912 (NSW); Alectown South, Constable NSW 17466, 3.10.1951 (NSW); Bogan Gate, Boorman NSW 116131, 11.1906 (NSW); Forbes district, Curtin NSW 116124, 12.12.1952 (NSW); Morangarell, per Esplin Pty. Ltd. NSW 116128, 1938 (NSW); Young, Patterson NSW 116125, 12.1917 (NSW); Temora, Dwyer NSW 116136, 10.1916 (NSW). South Western Slopes: between Illabo \& Eurongilly, Moore 1106, 18.11.1948 (CANB); Wagga Experimental Farm, Bonen, McKeown NSW 116130, 3.12.1906 (NSW); 7 miles $[11 \mathrm{~km}] \mathrm{N}$. of Wagga Wagga, Phillips CBG 025123, 20.10.1965 (CBG); near Mangoplah, Moore $1121,30.11 .1948$ (CANB); 4 miles [6 km] N. of Pleasant Hills, McBarron 4569 , 14.6.1950 (NSW); Alma Park near Culcairn, McBarron 4696, 14.7.1950 (NSW); 8 miles [13 km] N. of Burrumbuttock, McBarron 4661, 26.6.1950 (NSW); Balldale, McBarron 4730, 2.8.1950 (NSW).

North Western Plains: West Bogan, Nyngan, Butchee NSW 116109, 116131, 20.11.1934 (NSW, K).

South Western Plains: Trida district, Stannard NSW 116822, 8.10.1956 (NSW); $8 \mathrm{~km}$ S. of Lake Cargellico, 33 $23^{\prime} \mathrm{S}, 146^{\circ} 22^{\prime} \mathrm{E}$, Everett 218 \& Jacobs, 2.12.1980 (NSW); Monia Gap, Constable NSW $4605,29.10 .1947$ (NSW); Griffith, Vickery NSW 10183, 18.10.1949 (NSW); Benerembah, Griffith, McKie NSW 2520, 27.10.1938 (NSW); Jerilderie district, Dykes NSW 116113, c. 1880 (NSW); Wakool Reserve, Henderson 125, 10.11.1945 (NSW); Myall Plains, Berrigan, O'Niell NSW 116121, 20.10 .1935 (NSW); 4 miles [6 km] NE. of Henty, Flynn NSW 116115, 23.10.1969 (NSW); Deniliquin, Williams 41, 10.1947 (CANB); Gerogery, McBarron 2462, 1.11.1948 (NSW). Far South Western Plains: 'Milton Grove', c. 60 miles $[96 \mathrm{~km}] \mathrm{SW}$. of Ivanhoe on Mildura road, De Nardi $1105,24.10 .1972$ (NSW).

VICTORIA: Region C: Jung, near Horsham, Beauglehole NSW 116126, 26.10.1963 (NSW, CANB); Mt Arapiles, Beauglehole 30679, 15.5.1969 (MEL). Region G: 15 miles [24 km] SSW. of Kerang, Beauglehole 40671, 1.11.1972 (MEL, NSW). Region H: 5 miles [8 km] from Wedderburn, Phillips CBG 003138, 31.10.1963 (CBG). Region M: Tatura, Gauba CBG 047569, 30.10.1945 (CBG); near Kamarooka, Robins 7975, 26.10.1947 (NSW); between Murchison \& Nagambie, Corrick 3414 , 24.9.1973 (Corrick Herb); Bendigo, Robins 7968, 1.11.1948 (NSW). Region N: Studley Park, Melbourne, Muir 24, 28.9.1956 (MEL). Region R: Yarrawonga to Benalla road, 4 miles [ $6 \mathrm{~km}]$ from Hume Highway, Muir 1760, 2.11.1960 (MEL). Region V: Sawpit Creek, Wakefield s.n., 19.5.1969 (MEL 1509948). Region W: between Swifts Creek \& Omeo, Hewitt (MEL 60667); S. of Lauries Track, East Gippsland, Beauglehole 37217, 5.3.1971 (NSW). 
South Australia: Flinders Ranges: Fergusons Gorge, 'Moolooloo' Station, Ising 707, 9.10.1918 (AD); Wilpena Pound, Crisp 919, 22.10.1974 (NSW, CBG); Alligator Gorge, Hilton, 5.8.1952 (ADW 44090); Mt Remarkable, Mueller (MEL 60664, 60665); 5 miles [8 km] from Melrose, Hilton, 12.9.1951 (ADW 43838, 44048, 44050); Melrose Showground, Copley 3207, 12.10.1970 (AD). Eastern: Morialta Reserve, Spooner 672, 2.11.1969 (AD). Northern Lofty: Barunga Range, Bute to Snowtown road c. $40 \mathrm{~km}$ NNW. of Port Wakefield, Copley 739, 20.10.1966 (AD); 1.5 km E. of Barunga Gap Siding, Copley 762, 15.10.1966 (NSW, AD); South Hummocks Range, Copley 3227, 25.10.1970 (AD); Tothill Range, Kraehenbuehl 1098, 27.10.1963 (AD); Saddleworth, Symon 789, 27.10.1960 (ADW); Balaklava, 42 miles [67 km] NNW. of Gawler, Hilton NSW 116812, 1.10.1944 (ADW, NSW); c. $1 \mathrm{~km} \mathrm{~S}$. of Freeling, Kraehenbuehl 1450, 18.9.1965 (AD). Murray: 1 mile [2 km] E. of Kanmantoo, Hilton. 7.12.1954 (ADW 44136). Yorke Peninsula: Port Germain Pass, Hilton, 12.9.1951 (ADW 43842 to 43846). Southern Lofty: Roseworthy College, Hilton, 23.8.1941 (ADW $43840)$; c. $1 \mathrm{~km} \mathrm{~W}$. of Angle Vale road and western side of Parafield aerodrome, Kraehenbuehl 1451, 18.9.1965 (AD); Modbury, Spooner 1273, 24.10.1970 (AD); Torrens Gorge, Spooner 525, 4.10.1969 (AD); Black Hill near Athelstone Oval, Spooner 344, 30.10.1968 (AD); Marino Rocks, Smith 693, 10.9.1967 (AD): Mt Barker, Liebelt, summer 1936-1937 (ADW 2670); Hallett Cove, Cleland, 24.9.1932 (AD). South-eastern: Greenhill Road E. of Adelaide, Cleland, 9.10.1948 (AD).

WeSTERN AUSTRALIA: Austin: Ninghan, Storr 3301, 19.10.1959 (PERTH); between Kunnunoppin and Mt Marshall \& Lake Barlee, Fitzgerald Fraser NSW 116813, winter-spring 1919 (NSW). Coolgardie: Merredin, Maiden NSW 116814, 10.1909 (NSW).

$S$. blackii is at times difficult to distinguish from $S$. aristiglumis. The coma of $S$. aristiglumis is usually much shorter and less regular. In $S$. blackii the young leaves are shortly pubescent with scattered stiff hairs amongst the pubescence. In $S$. aristiglumis the leaves, sheaths and culms are mostly glabrous and smooth.

\section{Stipa blakei J. Vickery, S.W.L. Jacobs \& J. Everett, sp. nov.}

$S$. tenuifoliae affinis sed auriculis glabris vel vix pilosis, nodis plerumque tumidis, panicula plerumque sparsiore differt.

HolotyPE: QueENSLAND: Warrego: Charleville, S.T. Blake 11024, 4.4.1936. Open places on sand ca. $950 \mathrm{ft}$. Tufted, erect, $2-3 \mathrm{ft}$., dark green, spikelets paler (BRI 250581).

Caespitose perennial 0.3 to c. 1 metre high with a contracted rootstock. Culms robust, narrow, 1-2 mm wide near the base, terete, smooth or slightly ribbed, glabrous or minutely retrorsely puberulous especially just below the nodes; nodes 2-4, glabrous, usually conspicuously thickened (to $60 \%$ broader than adjacent internodes), exserted. Leaf sheaths narrow, tight around the culms (except that subtending the panicle slightly broader and looser), slightly ribbed, sparsely to densely retrorsely puberulous between the ribs, the very basal sheaths pubescent; outer margin glabrous to ciliate just below the orifice; inner margin glabrous. Ligule truncate to broad-ovate, $1-2.5 \mathrm{~mm}$ long, lightly ciliate, otherwise glabrous; auricles glabrous or with a few short hairs. Leaf blades linear, loosely rolled, to $28 \mathrm{~cm}$ long, $1.5-2 \mathrm{~mm}$ wide; abaxial surface glabrous and smooth, sparsely but strongly scabrous with short rigid hairs, or pubescent (especially between the nerves and at the back of the orifice); adaxial surface very strongly ribbed, ribs densely pubescent. Panicle $20-35 \mathrm{~cm}$ long, $2-3 \mathrm{~cm}$ wide (excluding awns) sparse and spreading, with distant fascicles of unequal compound branches, the base exserted; axis terete, ribbed, glabrous, scaberulous or finely pubescent; branches very fine, $3-6 \mathrm{~cm}$ long, pedicels very fine, flattened, especially near the apex, 7-25 mm long, minutely scaberulous on the edges. Spikelets scarcely gaping, 14-18 mm long (excluding awn). Glumes subequal, long-acute to acuminate, firm at the base but mostly hyaline, glabrous; lower glume $14-18 \mathrm{~mm}$ long, lower $60 \% 3$-nerved; upper glume 13-17 mm long, lower 50\% 5-nerved. Floret narrow-cylindrical, 7-8 mm long (including callus). Lemma only loosely enclosing the palea and caryopsis, 
visually tuberculate (but so minutely as to feel smooth), dark brown at maturity, with sparse, short, dull white to yellowing hairs, sparsest at the apex, densest on the margins; lobes 2, c. $0.1-0.2 \mathrm{~mm}$ long, coma absent. Callus straight, 2.5-3 mm long, with hairs similar to those on the lemma. Awn robust, $0.3-0.4 \mathrm{~mm}$ wide near the base, $7-10 \mathrm{~cm}$ long, strongly falcate; column $9-13 \mathrm{~mm}$ long, pubescent with spreading antrose hairs $0.2-0.3 \mathrm{~mm}$ long; bristle scabrous, much paler than the column at maturity. Palea very broadly obtuse, firm but the margins more delicate, subequal to the lemma, with similar hairs scattered down the back. Lodicules 2, abaxial, long-cuneate c. $2 \mathrm{~mm}$ long. Anthers c. $3 \mathrm{~mm}$ long, lightly penicillate. Caryopsis c. $4.5 \mathrm{~mm}$ long.

DISTRIBUTION: Mainly on sandy soils in western Queensland.

SPECIMENS EXAmINED: QUEENSLAND: Leichhardt: Cairdbeign via Springsure, Norton, 2.1903 (BRI 228952); from the Dawson, [? Leichhardt] 322, 16.1.1847 (MEL 60005). Mitchell: Williwin, 12 miles [19 km] W. of Yalleroi, Everist 1837, 23.6.1939 (BRI). Warrego: Chesterton, c. 25'20'S, 147²0'E, Blake 11104, 7.4.1936 (BRI, NSW); Charleville, Blake 11024, 4.4.1936 (BRI, NSW); $10 \mathrm{~km}$ ENE of "Maryvale" homestead, 26 $34^{\prime}$ 'S, $146^{\circ} 58^{\prime} \mathrm{E}$, Purdie $368 \mathrm{D}, 17.6 .1976$ (BRI, 2 sheets). Maranoa: Mitchell, Blake 5690, 4.4.1934 (BRI, NSW); 'Amby Downs', Scortechini, 12.1883 (NSW); Wycanna, $134 \mathrm{~km} \mathrm{~W}$. of Goondiwindi, 28 $02^{\prime}$ S, $149^{\circ} 01^{\prime}$ E, C.H.P. YI644, 30.5.1974 (BRI, CANB); Nindigully, Willoughby 17, 4.1940 (BRI).

This species is named after Dr S.T. Blake, a Queensland botanist who, over many years, advanced our knowledge of the taxonomy of Australian grasses.

It differs from $S$. tenuifolia in the glabrous or very sparsely hairy auricles, the usually swollen nodes and in the usually sparser panicle. It differs from $S$. nodosa in the glabrous or very sparsely haired auricles and the stronger awn.

Stipa breviglumis J. Black, Trans. \& Proc. Roy. Soc. S. Austral. 65: 333 (1941); Willis, Handb. Pl. Victoria 1: 181 (1962), edn 2: 181 (1970).

SyNTYPES: South Australia: cited as 'Lyndoch, Oct. 1927, J.B. Cleland; Mount Brown, Nov. 1881 (in Tate Herb.)'. At AD there is a sheet from Cleland's herbarium labelled 'Lyndoch 8.10 .27 in J.B. Cleland's handwriting, and the initials "J. M. B." (associated with an unpublished epithet) in Black's handwriting; Black has not written the epithet 'breviglumis' on it, but it is evident that he saw and examined it. This sheet bears a satisfactory specimen and we designate it as the Lectotype. A small duplicate of this specimen is at MEL (MEL 59884) and bears the name 'breviglumis' and collecting data in Black's handwriting. In AD there is also a sheet from the Tate herbarium bearing a single panicle surmounting a portion of a culm, alongside which Black has written the name Stipa breviglumis; the sheet also bears three other panicles, two of which are $S$. platychaeta and the third a species of the Falcatae. In describing this species as a robust rigid grass, Black must have had in mind the Cleland specimen that clearly shows this character, whereas the Tate herb. specimen is inadequate to support his statement.

Caespitose or very shortly rhizomatous perennial c. 1.5 metres high, often with several branches at the nodes, without a basal tuft of leaves. Culms erect or slightly geniculate at the base, terete, c. $2.5(-4) \mathrm{mm}$ wide near the base, not compressible, slightly to moderately ribbed, glabrous; nodes 2-4, exserted, glabrous, to $50 \%$ wider than the adjacent internodes. Leaf sheaths \pm inflated, minutely puberulous or scaberulous with minute tubercles, glabrous; basal sheath to $1 \mathrm{~cm}$ wide, slightly to strongly ribbed; upper sheath $3.5-4 \mathrm{~mm}$ wide, moderately ribbed. Ligule truncate, membranous, 1-7 $\mathrm{mm}$ long, glabrous; auricles \pm thickened, c. $1 \mathrm{~mm}$ long. Leaf blade expanded or loosely inrolled, 2-2.5 mm wide, to $20 \mathrm{~cm}$ long; adaxial surface strongly ribbed, minutely puberulous or scabrous with minute tubercles; abaxial surface strongly ribbed, glabrous; margins glabrous. Panicle 20-40 cm long, exserted, with distant fascicles of unequal, few-flowered, branches, contracted, 2-4 cm wide (excluding 
awns); axis slightly angular or terete and strongly ribbed, glabrous to minutely puberulous; branches $5-10 \mathrm{~cm}$ long, slightly angled or terete and moderately ribbed, minutely sericeous along the ribs or edges; pedicels 2-6 mm long, slightly angled, minutely sericeous. Spikelets 5-6.5 mm long (excluding awn), gaping. Glumes subequal, acute-acuminate, hyaline with chlorenchyma bands associated with the nerves, sericeous with hairs minute- $0.3 \quad(-0.5) \mathrm{mm}$ long; lower glume 5.5-6.5 mm long, lower 30-65\% 5-3-nerved, upper 35-70\% 3-1nerved; upper glume 4.5-6 mm long, lower 75-95\% 3-nerved, upper $25-5 \% 1$ nerved. Floret narrowly cylindrical tapering to a slender neck, 3-4.5 mm long (including callus). Lemma slightly granular, with white hairs $0.2-0.4 \mathrm{~mm}$ long; lobes absent; coma sparse, c. $0.2 \mathrm{~mm}$ long. Callus c. $0.5 \mathrm{~mm}$ long, slightly curved, the tip blunt, sericeous with white hairs minute- $-0.5 \mathrm{~mm}$ long. Awn $2-3.5 \mathrm{~cm}$ long with $1-2$ bends, $0.1-0.2 \mathrm{~mm}$ wide near the base; column $1-1.5 \mathrm{~cm}$ long, 5-6.5 mm to the first bend, straw-coloured to brown with 2 chlorenchyma bands, minutely scabrous; bristle often darker than the column, minutely scabrous. Palea $50-60 \%$ the length of the lemma, obtuse, sparsely sericeous along the centre back with white hairs $0.1-0.4 \mathrm{~mm}$ long. Lodicules $3 ; 2$ abaxial, membranous, c. $0.25 \mathrm{~mm}$ long, obtuse; paleal membranous, c. $0.25 \mathrm{~mm}$ long, laciniate. Anthers c. $1.25 \mathrm{~mm}$ long, minutely penicillate. Mature caryopsis not seen.

Distribution: Central and southern Victoria and into the Lofty Regions of South Australia.

Selected Specimens: Victoria: Region H: St Arnaud, Rouell, s.d. (BRI). Region M: Kamarooka, N. of Bendigo, Morris, 10.1947 (MEL 5985); Kamarooka Forest, $30 \mathrm{~km}$ NNE. of Bendigo, Beauglehole 55242 \& Kellam, 17.10.1976 (ACB, NSW); Rushworth State Forest (Forest Park N. of Graytown), Corrick 3578, 3.11.1973 (Herb Corrick). Region N: Lerderderg Gorge, Kenna, 3.6.1956 (MEL 59886); Coimadai Lane, off Bacchus Marsh Road, c. 28 miles [45 km] from Melbourne, no collector, 1935 (MEL 59888).

SOUTH Australia: Flinders Ranges: Alligator Gorge, Wilmington, Cooper, 14.8.1954 (AD 966071541); Alligator Creek, Ising NSW 116024, 23.10.1928 (NSW, ADW). Northern Lofty: Northern Tothill Range, Niblet Gap, c. 30 km NE. of Marrabel, Kraehenbuehl 2177, 29.10.1967 (AD). Southern Lofty: Lyndoch, Cleland, 8.10.1927 (BRI, fragment from Lectotype); Finniss, Cleland, 10.8.1963 (AD 97210220); Goolwa, Railway line to Currency Creek, Cleland, 17.8.1940 (AD 96323293).

S. breviglumis differs from $S$. verticillata in having firmer, not hyaline, rather broader and more scabrous glumes, and a relatively longer $(60-70 \%$ of lemma length) and more hairy palea. $S$. breviglumis is widespread but uncommon and tends to grow under trees or scrub and on rocky areas whereas $S$. verticillata tends to grow in open grasslands. Black, Fl. S. Austral. edn 2: 92 (1943), and Eichler, Suppl. to Black's Fl. S. Austral.: 49 (1965), incorrectly identified specimens of $S$. breviglumis as $S$. verticillata.

Stipa campylachne Nees in Lehmann, Pl. Preiss. 2: 99 (1846).

S. semibarbata var. campylachne (Nees) Benth., Fl. Austral. 7; 569 (1878); Gardner, Fl. W. Austral. 1, Gram.: 179 (1952). Based on S. campylachne.

TYPIFICATION: Nees cites: 'In solo sublimoso jugi montium Darling's-range, Perth. Herb. Preiss No. 1848. Ad flumen Cygnorum. Drummond'. Nees' herbarium was in B and has been destroyed. Preiss' herbarium is now at LD with a substantial set of duplicates at MEL. There is one specimen of Preiss 1848 at LD; this specimen is S. tenuifolia and it is not a good match for the original description as it lacks both a white-pubescent column and hairy sheaths. There is no annotation by Nees on the specimen and, presumably, he did not see it. In MEL there are two sheets of Preiss No. 
1848 which have been annotated $S$. campylachne Nees but which manifestly represent two entirely different species. One of these sheets, MEL 59990, bears a complete, rather robust culm with panicle bearing glumes and an imperfect floret, a packet containing other more or less imperfect florets, and a fascicle of strongly hirsute-pubescent leaves with the lower part of a culm. This specimen is a good match for the protologue despite the absence of mature florets. In many ways the specimen strongly resembles $S$. semibarbata $\mathrm{R}$. Br., but differs in its shorter lemma, column and bristle. The other sheet, $M E L 59950$, bears a plant with a strongly curved falcate bristle above the more or less straight, erectly pubescent column and is $S$. tenuifolia Steud. The florets could not, in any respect, be said to resemble either $S$. pubescens or $S$. semibarbarta with which $S$. campylachne was associated by Nees, and later with $S$. semibarbata by Bentham and Hughes. This specimen is presumably a true duplicate of Preiss 1848 at LD. We have therefore based the following concept of S. campylachne on the sheet MEL 59990 and we here designate this as the Lectotype. There is a duplicate of this specimen in $\mathrm{S}$ but it has only one immature fruit remaining.

Caespitose perennial c. 0.8 metres high, not rhizomatous, with a basal tuft of leaves c. half the height. Culms erect or geniculate at the base, $1-2 \mathrm{~mm}$ wide near the base, \pm compressible, terete, slightly ribbed to smooth; basal culms pubescent with hairs $0.1-0.4 \mathrm{~mm}$ long to $0.8 \mathrm{~mm}$ near the nodes; upper culms glabrous to pubescent with hairs minute to $0.4 \mathrm{~mm}$ long; nodes $2-4$, exserted, densely sericeous with hairs $0.2-0.6 \mathrm{~mm}$ long, c. $50 \%$ wider than the adjacent internodes. Leaf sheaths tightly enveloping the culm, basal sheath $5-8 \mathrm{~mm}$ wide, pubescent to hirsute with hairs to $1 \mathrm{~mm}$ long, slightly to moderately ribbed, inner margin glabrous, outer margin ciliate with hairs $0.1-0.4 \mathrm{~mm}$ long; upper sheath 4-5 mm wide, pubescent to hirsute with hairs to $1 \mathrm{~mm}$ long, also with hairs $1.5 \mathrm{~mm}$ long around the collar, strongly ribbed, inner margin glabrous, outer margin ciliate with hairs similar to those on the abaxial surface. Ligule truncate, membranous, $0.3-0.6 \mathrm{~mm}$ long, minutely ciliate; auricle sometimes present to $1.5 \mathrm{~mm}$ long, glabrous. Leaf blade weakly rolled, $1.5-2 \mathrm{~mm}$ wide, up to $35 \mathrm{~cm}$ long; abaxial surface strongly ribbed, the surface slightly scabrous with minute tubercles, pubescent to hirsute with hairs $(0.1-) 0.3-0.9 \mathrm{~mm}$ long; adaxial surface strongly ribbed, pubescent to hirsute with hairs (minute-) $0.2-0.4 \mathrm{~mm}$ long; margins sparsely ciliate with hairs $0.5-0.7(-1.5) \mathrm{mm}$ long. Panicle $10-20 \mathrm{~cm}$ long, exserted, with distant fascicles of unequal, few-flowered, compound branches, contracted (but spreading at anthesis), $2-3 \mathrm{~cm}$ wide (excluding awns); axis slightly flattened to terete, scabrous with stiff hairs $0.05-0.3 \mathrm{~mm}$ long; branches angular to slightly flattened, $2-3 \mathrm{~cm}$ long, scabrous along the edges with stiff hairs $0.1-0.3 \mathrm{~mm}$ long; pedicels angular, $0.2-1 \mathrm{~cm}$ long, scabrous with stiff hairs $0.05-0.3 \mathrm{~mm}$ long. Spikelets $14-23 \mathrm{~mm}$ long (excluding awn) gaping. Glumes subequal to equal, acuminate, scabrous along the nerves with hairs $0.05-0.25 \mathrm{~mm}$ long, sparsely scabrous between the nerves with hairs minute- $0.15 \mathrm{~mm}$ long, hyaline, chorenchyma bands associated with the nerves; lower glume $15-23 \mathrm{~mm}$ long, lower $40-55 \%$ 3-nerved, upper $45-60 \%$ 2-1-nerved; upper glume 14-18 mm long, lower 35\% 5-nerved, upper $65 \%$ 4-1nerved. Floret cylindrical, without a neck, $8-9 \mathrm{~mm}$ long (including callus). Lemma surface smooth to scabrous upwards, with sparse hairs $0.3-1 \mathrm{~mm}$ long; lobes absent; coma absent. Callus 2-2.5 mm long, densely sericeous with hairs $0.2-0.8 \mathrm{~mm}$ long, tip glabrous and weakly bent. Awn $5-7 \mathrm{~cm}$ long, twice bent, $0.4 \mathrm{~mm}$ wide near the base; column c. $30 \mathrm{~mm}$ long, c. $20 \mathrm{~mm}$ to the first bend, straw-coloured, pubescent to plumose with hairs $(0.3-) 0.5-1(-1.6) \mathrm{mm}$; bristle straw-coloured, scabrous with hairs c. $0.1 \mathrm{~mm}$ long. Palea equal to the lemma, acute, surface smooth, with sparse hairs $0.5-0.8 \mathrm{~mm}$ long down the centre, margins hyaline. Lodicules 2, abaxial, membranous, (1.2-) 1.6-1.8 (-2.4) mm long, obtuse. Anthers $2.5-3.5 \mathrm{~mm}$ long \pm penicillate. Caryopsis $4-5 \mathrm{~mm}$ long; embryo $20 \%$ the length; hilum $80-100 \%$ the length.

DisTRIBUtion: The south-west of Western Australia. 
Selected Specimens: Western Australia: Darling: Smiths Mill, Morrison, 13.11.1897 (BRI); Mundaring, Helms, 25.7.1897 (PERTH); Welshpool to Kalamunda, Maiden, 9.1909 (NSW 116932); Armadale, Symon, 9.1954 (ADW 28146); Wungong Gorge near Armadale, Blake 18019, 24.8.1947 (BRI, PERTH); Araluen, Darling Range, in Jarrah forest, Burbidge 3641, 9.12.1951 (CANB); Darling Range, Morris, 9.1947 (MEL 60829, 60830); Pinjarra, Helms, 27.9.1897 (PERTH); Harvey, no collector, 1911 (PERTH); Hamel near Drakesbrook, Blake 18045, 31.8.1947 (BRI); Upper Blackwood R. on wooded ridges, Mueller, 10.12.1877 (MEL 60831); banks of Blackwood R., Oldfield 675 (MEL 60687); 39.4 miles [63 km] from Collie towards Williams, Canning CBG 039953, 1.10.1968 (CBG); Capel, Royce 2684, 24.9.1948 (PERTH). Warren: 3 miles [5 km] W. of Mayanup, Burbidge 2551, 9.12.1951 (CANB); Mt Barker, Mueller, 10.1867 (MEL 60820); King Georges Sound, Muir, s.d. (MEL 60810).

$S$. campylachne is close to $S$. semibarbata but the distinctive hirsutepubescence of its foliage in many specimens, the usually narrower, more delicate glumes and shorter lemma, column and bristle, appear to make it worthy of separate recognition in specific rank.

*Stipa caudata Trin., Mém. Acad. Imp.Sci.- St. Pétersbourg Sér. 6, Sci. Math 1: 75 (1830); Rosengurtt, de Maffei \& de Artucio, Gramineas Uruguayas: 73 (1970); Caro \& Sanchez, Darwiniana 16: 643 (1971).

HOLOTYPE: "V. spp. chilens" (LE, not seen), said to be a Lindley collection from Chile, s.n., s.d.

Caespitose perennial $0.75-1$ metre high with a basal tuft half to three quarters the height, without rhizomes. Culms erect, terete to slightly angled, not compressible, slightly ribbed at the base to smooth or strongly ribbed upwards, glabrous; nodes $2-4, \pm$ exserted, glabrous, not swollen. Leaf sheaths tightly enveloping the culm, sometimes becoming loose upwards, glabrous; basal sheaths $6.5-7 \mathrm{~mm}$ wide, slightly ribbed, margins glabrous; upper sheaths $3-3.5 \mathrm{~mm}$ wide, strongly ribbed, inner margin with hairs $0.4-0.6 \mathrm{~mm}$ long to glabrous, outer margin with hairs $0.5-1.5 \mathrm{~mm}$ long to glabrous. Ligule truncate to obtuse, membranous, $0.1-0.5 \mathrm{~mm}$ long, ciliate with hairs $0.2-1.5 \mathrm{~mm}$ long, also with a tuft of hairs present at the sides; auricles, if present, thickened, c. $0.8 \mathrm{~mm}$ long, glabrous. Leaf blade expanded to tightly rolled, $1-2.5 \mathrm{~mm}$ wide, to $50 \mathrm{~cm}$ long; abaxial surface strongly ribbed, glabrous; adaxial surface strongly ribbed, minutely scabrous along the ribs; margin with hairs $0.2-1 \mathrm{~mm}$ long to minutely scabrous. Panicle $15-25 \mathrm{~cm}$ long, exserted, with distant fascicles of unequal, few-flowered, compound branches, contracted, c. $2.5 \mathrm{~cm}$ wide (excluding awns); axis terete to slightly flattened, strongly ribbed, scaberulous with sparse minute hairs; branches $1.5-6 \mathrm{~cm}$ long, angled, scaberulous along the edges with hairs minute- $0.2 \mathrm{~mm}$ long; pedicels $0.1-1 \mathrm{~cm}$ long, slightly angled, scaberulous along the edges with hairs minute $-0.3 \mathrm{~mm}$ long. Spikelets $6-9 \mathrm{~mm}$ long (excluding awn), gaping. Glumes subequal, hyaline with chlorenchyma bands associated with the nerves, acuminate; lower glume 6-9 mm long, glabrous or scaberulous along the midrib with hairs minute- $0.2 \mathrm{~mm}$ long, the margins with sparse hairs $0.05-0.1 \mathrm{~mm}$ long, lower $40-65 \%$ 3-nerved; upper glume $6-9.5 \mathrm{~mm}$ long, scaberulous along the midrib with hairs $0.1-0.2 \mathrm{~mm}$ long to glabrous, lower 50-60\% 3-nerved, upper 40-50\% 1-nerved. Floret cylindrical, 4-6 mm long (including callus), without a neck. Lemma surface scaberulous with minute tubercles, with hairs $0.2-1 \mathrm{~mm}$ long along the midrib and margins; lobes $0.3-0.4 \mathrm{~mm}$ long, coma of hairs $0.2-1 \mathrm{~mm}$ long. Callus c. $0.6 \mathrm{~mm}$ long, straight, blunt, densely sericeous with white hairs $0.1-1 \mathrm{~mm}$ long. Awn $1.2-1.8 \mathrm{~cm}$ long, twice bent, $0.1-0.2 \mathrm{~mm}$ wide near the base; column $6-9 \mathrm{~mm}$ long, $3-4 \mathrm{~mm}$ to 
the first bend, straw-coloured, scaberulous with hairs minute- $-0.2 \mathrm{~mm}$ long; bristle straw-coloured, scaberulous with hairs minute- $0.2 \mathrm{~mm}$ long. Palea \pm equal to the lemma, acute, the surface smooth to granular, sericeous along the centre back with hairs $0.2-0.8 \mathrm{~mm}$ long, margins glabrous. Lodicules $3 ; 2$ abaxial, membranous, oblong, $1-1.3 \mathrm{~mm}$ long; paleal membranous, acute, c. $0.5 \mathrm{~mm}$ long. Anthers $3-3.5 \mathrm{~mm}$ long, penicillate. Only immature caryopsis seen, obovate, c. $3 \mathrm{~mm}$ long, embryo $30 \%$ the length, hilum c. $80 \%$ the length, the stylar appendage eccentric.

Distribution: An introduction from South America, uncommon on roadsides on the Western Slopes of New South Wales; also scattered on Flinders I. in Bass Strait.

Selected Specimens: New South Wales: Central Western Slopes: Merriwa district, Henderson NSW 117377, 15.11.1955 (NSW), Merriwa Shire Council NSW 117378, 1.1956 (NSW). South Western Slopes: Cootamundra district, Christenson NSW 117379, 5.11.1959 (NSW).

TASMANIA: Flinders Island: Emita, Warren NSW 117376, 4.12.1979 (NSW).

$S$. caudata has been known in Australia as $S$. brachychaeta Godron, Mém. Sect. Sci. Acad. Sci. Montpellier 1: 450 (1853). (The latter name appears on some of our determinavit labels.) These two South American species are difficult to distinguish. They are generally said to be distinguished by: (i) $S$. caudata having hairs on the margins and midrib of the lemma, and a broader caryopsis with an eccentric stylar appendage; (ii) S. brachychaeta having hairs all over the lemma surface, and a narrower caryopsis with a centric stylar appendage. The type of $S$. brachychaeta (Godron (NYC!)) has lemmas showing both character states on the one inflorescence. In Australian specimens, the only caryopses we have found are immature and in a glasshouse-grown specimen (Morris, 19.1.1981 (HO)); and these match the description of S. caudata. We have as yet been unable to find caryopses of either $S$. brachychaeta or $S$. caudata for comparison. We are using the earlier name $S$. caudata although we are not yet convinced the situation is fully understood.

\section{Stipa centralis J. Vickery, S.W.L. Jacobs \& J. Everett, sp. nov.}

S. eremophilam aemulans sed cataphyllis et vaginis foliorum basalium lanatis, pilis lemmatis pallidioribus sparsioribusque, differt.

HOLOTYPE: NORTHERN TERrITORY: Mt Riddock $23^{\circ} 06^{\prime} \mathrm{S}, 134^{\circ} 38^{\prime} \mathrm{E}$. Erect perennial. Common in skeletal soil, southern slope of metamorphic hill. P.K. Latz 4305, 13 Sept. 1973 (NT 41138).

Caespitose perennial to c. 0.8 metres high, with a short rhizome. Shoots conspicuously extravaginal, the basal leaves at least as long as the culms. Culms numerous, terete, very tough, c. $1 \mathrm{~mm}$ wide near the base, glabrous, smooth; nodes 4-5, glabrous, exserted. Leaf sheaths tight around the culms, minutely puberulous to glabrous, but the cataphylls and most basal sheaths densely woolly with long, soft, slightly spreading hairs. Ligule acute, coriaceous, 0.6-1 mm long, densely sericeous on the back. Leaf blades linear, to $25 \mathrm{~cm}$ long, c. $1.5 \mathrm{~mm}$ wide, loosely inrolled; abaxial surface slightly ribbed, smooth, glabrous; adaxial surface very strongly ribbed, minutely scabrous; margins glabrous to scabrous. Panicle, with distant fascicles of few-flowered branches, very sparse, with less than 30 spikelets, $10-20 \mathrm{~cm}$ long, $1-2.5 \mathrm{~cm}$ wide (excluding awns), exserted but not exceeding basal leaves; axis, pedicels and branches angular, scaberulous with sparse, short, stiff hairs; branches $15-40 \mathrm{~mm}$ long; pedicels slender, 3-25 mm long. Spikelets gaping, 13-18 mm long (excluding awn). Glumes slightly unequal, broad, acuminate, hyaline, the tips easily torn; densely 
short-scabrous to pubescent to glabrous at the tips; lower 13-18 mm long, 3nerved; upper 12-16 $\mathrm{mm}$ long, 5-nerved to the middle. Floret $7-9 \mathrm{~mm}$ long (including callus), narrow-turbinate. Lemma pale to dark brown at maturity but the central nerve very pale and visible; with sparse white hairs at the base; becoming glabrous upwards between the nerves; surface finely granular to finely retrorsely hooked-tuberculate upwards; lobes 2 , c. $0.3 \mathrm{~mm}$ long or minute or absent; coma absent or a few hairs to $0.3 \mathrm{~mm}$ long present. Callus straight, $1.5-2.5 \mathrm{~mm}$ long, sericeous with dense yellowish hairs. Awn c. $0.3 \mathrm{~mm}$ wide, 50-60 mm long, twice bent; column 19-25 mm long, $12-13 \mathrm{~mm}$ to the first bend, pubescent with slightly spreading hairs $0.25-0.4 \mathrm{~mm}$ long; bristle scabrous. Palea to $0.8 \mathrm{~mm}$ shorter than the lemma, acute, ciliate-tipped, granular, sparsely hairy down the middle of the back. Lodicules $2-3$, c. $1 \mathrm{~mm}$ long; 2 abaxial, linear to slightly spathulate; paleal acute or absent. Anthers $0.8-1.5 \mathrm{~mm}$ long, penicillate. Mature caryopsis not seen, apparently c. $2.5 \mathrm{~mm}$ long.

DistRIBUTION: Slopes of the Central Australian Ranges.

Selected Specimens: Northern Territory: Central Australia: Mt Palmer, Harts Range, $23^{\circ} 06^{\prime} \mathrm{S}$,

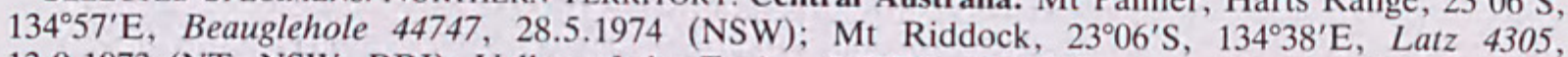
13.9.1973 (NT, NSW, BRI); Valley of the Eagles, $23^{\circ} 37^{\prime} \mathrm{S}, 134^{\circ} 27^{\prime} \mathrm{E}$, Beauglehole 44945, 2.6.1974 (NT, NSW); 5 km SE. of Reedy Rockhole, $24^{\circ} 19^{\prime} \mathrm{S}, 131^{\circ} 38^{\prime} \mathrm{E}$, Latz 8997, 18.8.1982 (NSW, duplicate from NT).

The specific epithet refers to the Central Australian distribution of this species.

Similar in appearance to $S$. eremophila but differing in the woolly cataphylls and basal leaf sheaths, and in the lighter-coloured and sparser hairs on the lemma.

Stipa compressa $R$. Br., Prodr.: 175 (1810); Bentham, Fl. Austral. 7: 567 (1878); Hughes, Kew Bull. 1921: 26 (1921); Gardner, Fl. W. Austral. 1, Gram.: 176 (1952).

Holotype: Western Australia: King Georges Sound, A. Menzies (BM!).

SYNONYM: S. longearistata Steudel, Syn. PI. Glum. 1: 127 (1854). HolotyPE: Cited as 'Urville legit ad Port George, N. Holl.' (not seen). Steudel's descriptions could only apply, as indeed he himself suggests, to a plant of $S$. compressa $\mathrm{R}$. Br.

Caespitose annual (to short-lived perennial?) to 0.7 metres high, without rhizomes and with a basal tuft of slender shoots c. a quarter the height. Culms erect, mostly terete, \pm compressible, to $3.5 \mathrm{~mm}$ wide, slightly ribbed to smooth upwards, glabrous; nodes $2-5$, glabrous, concealed by the sheaths or at length exserted, to $25 \%$ wider than the adjacent internodes. Leaf sheaths usually inflated, glabrous to minutely scaberulous; basal sheaths broad, to $12 \mathrm{~mm}$ wide, slightly to strongly ribbed, inner margin glabrous, outer margin ciliate with hairs c. $1 \mathrm{~mm}$ long; upper sheaths $5-5.5 \mathrm{~mm}$ wide, strongly ribbed, inner margin sparsely ciliate with glistening hairs c. $0.5 \mathrm{~mm}$ long, outer margin ciliate with hairs $0.6-0.8 \mathrm{~mm}$ long. Ligule membranous, obtuse, entire to laciniate, longest on upper leaves, 4-11 mm long, minutely scaberulous on the abaxial surface, continuous on the upper sheaths with acute auricle lobes, the lobes glabrous or
minutely scaberulous on the abaxial surface; auricles thickened, $0.5 \mathrm{~mm}$ long, with hairs at the base. Leaf blades triangular to linear, either as broad and expanded at the base as the sheaths or to half the width, upwards loosely convolute, to $20 \mathrm{~cm}$ long; abaxial surface strongly ribbed, glabrous and smooth to scaberulous with minute hairs; adaxial surface strongly ribbed, densely and 
minutely scabrous to pubescent with hairs c. $0.2 \mathrm{~mm}$ long; margins glabrous or scabrous. Panicle contracted or at length narrowly spreading, with distant fascicles of many unequal simple or compound branches, $10-30 \mathrm{~cm}$ long (excluding awns), 1-4 cm wide; axis smooth and glabrous to minutely scabrous, \pm angled; branches to $10 \mathrm{~cm}$ long, glistening, scabrous with minute hairs; pedicels $0.5-2 \mathrm{~cm}$ long, angled, scabrous with hairs minute- $0.1 \mathrm{~mm}$ long. Spikelets 13-21 mm long (excluding awn), gaping. Glumes green to strawcoloured, translucent, glabrous to scabrous at the tips, very unequal; lower glume 13-21 mm long, acute to acuminate, lower (40-) 66\% 3-nerved, scabrous, glabrous at the base; upper glume 9-14 mm long, acute, lower $50(-66) \% 5$ nerved, upper $50(-33) \% 3-1$-nerved, glabrous to minutely scabrous at the tip. Floret narrow-cylindrical, $6.5-8.5 \mathrm{~mm}$ long (including callus). Lemma with 1 or 2 lobes to $0.25 \mathrm{~mm}$ long, smooth, white to pale yellow at maturity, at least the central nerve visible externally, shortly and stiffly pubescent with hairs white to grey at maturity $0.2-0.3 \mathrm{~mm}$ long; coma absent. Callus straight, $2.5-3.5 \mathrm{~mm}$ long, densely sericeous with hairs $0.2-0.5 \mathrm{~mm}$ long. Awn $8-14 \mathrm{~cm}$ long, $0.25-0.4 \mathrm{~mm}$ wide near the base, slightly twice bent; column dark brown at maturity, 2-4 cm long, $1.4-3 \mathrm{~cm}$ to the first more gradual but stronger bend, scabrous with hairs $0.05-0.2 \mathrm{~mm}$ long; bristle pale yellow, much paler than the column, scaberulous with hairs $0.05-0.1 \mathrm{~mm}$ long. Palea acute, subequal to the lemma, with hairs $0.2-0.3 \mathrm{~mm}$ long down the centre, the surface smooth, margins glabrous. Lodicules 2 or 3 , membranous; 2 abaxial oblong, 1-1.5 mm long; paleal absent or acute and c. $0.2 \mathrm{~mm}$ long. Anthers $1.5-2.5 \mathrm{~mm}$ long, not penicillate. Caryopsis $3-3.5 \mathrm{~mm}$ long; embryo $15-25 \%$ the length; hilum $80-90 \%$ the length.

DiSTRIBUTION: Mainly sandy areas near the coast of south-western Western Australia.

Selected Specimens: Western Australia: Darling: Yanchep, Aplin 2979, 12.10.1965 (PERTH); Middle Swan River, Sewell, 1894 (MEL 60920); Kings Park, Perth, Roe, 4.10.1934 (CANB 1233); South Perth, Carne, 11.11.1923 (PERTH); Cottesloe near mouth of Swan R., A.M. [?], 21.10.1899 (BRI); Claremont, Andrews, 10.1902 (PERTH); Helena Valley, Seabrook 435, 22.10.1977 (PERTH); S. of Jandakot, Aplin 1061, 10.1961 (PERTH); Armadale, Symon, 9.1954 (ADW 28127); Jandakot Marsupial Breeding Station, Lake Banganup, Western 9805, 2.11.1974 (PERTH); Forrestdale, c. 15 miles [24 km] SSE. of Perth, Man \& George 11, 7.11.1969 (PERTH); Pinjarra, Murray R., Helms, 22.9.1897 (PERTH); Harvey, Stoward NSW 116594, 10.1911 (NSW, K); Jindong, Royce 2864, 18.10.1948 (PERTH); nr. NW. side of Lake Unicup, S. of Tonebridge, Pullen 9975, 11.12.1874 (CANB, NSW); nr. Lake Muir, Christensen 181, 10.11.1970 (PERTH); Bow River, Jackson NSW 116596, 11.1912 (NSW); between Irwins Inlet \& Brookes Inlet, Jackson NSW 116597, 12.1912 (NSW). Eyre: Cape Arid National Park, E. of Esperance, Royce 9934, 1.12.1971 (PERTH).

\section{Stipa crinita Gaudich. in Freycinet, Voy. Uranie Bot.: 407 (1830).}

Holotype: Western Australia: 'Novae-Hollandiae ora occidentalis (baie des Chiens Marins)' [Shark Bay] collected by Labillardière (P!; isotypes G, FI-W). This specimen had been regarded as lost for some time (Hughes, Kew Bull. 1922: 21), causing much confusion in the use of the name. Fortunately, the specimen was found in $\mathrm{P}$ after having been misfiled some time ago. The specimen referred to by Hughes (ibid.) as $S$. flavescens is a specimen of $S$. pubescens.

Caespitose perennial to 1 metre high with very short rhizomes. Shoots conspicuously extravaginal. Culms erect, terete, (1.5-) 2-2.5 (-3.5) $\mathrm{mm}$ wide, finely to strongly ribbed, glabrous but minutely puberulous between the ribs on the lower parts and just below the nodes; nodes $2-4$, sericeous, exserted. Leaf sheaths tight around the culms and shoots, glabrous, lower sheaths sometimes puberulous; outer margin glabrous but sparsely long-ciliate on the basal sheaths; inner margin glabrous. Ligule broadly obovate to ovate, $0.5-2 \mathrm{~mm}$ long, shortto long-ciliate, puberulous on the back; auricles with several to many hairs c. 
$1 \mathrm{~mm}$ long in a tuft. Leaf blades flat or weakly rolled, to $30 \mathrm{~cm}$ long, $1.5-4 \mathrm{~mm}$ wide; abaxial surface ribbed, glabrous to sparsely pubescent on the ribs, densely puberulous to scaberulous between the ribs; adaxial surface ribbed, short- to long-pubescent and, in addition, antrorsely scabrous between the ribs; margins glabrous. Panicle linear, contracted, $15-30 \mathrm{~cm}$ long, densely flowered with close fascicles of unequal, many-flowered compound branches, base enclosed by the sheath until late maturity; axis sparsely scaberulous; branches $15-40 \mathrm{~mm}$ long, glabrous to scaberulous, slightly ribbed; pedicels slightly angular, 2-8 $\mathrm{mm}$ long, puberulous to scaberulous. Spikelet 9-15 mm long (excluding awn), not or only slightly gaping. Glumes acute or shortly acuminate, evenly textured from base to tip, green or bleached, rarely evenly purple-tinged, unequal, puberulous to scaberulous, sometimes glabrous between the nerves; lower glume 9-15 mm long, the lower 65-75\% 3-nerved; upper glume 7.5-11.5 mm long, lower 30\% 4-5-nerved, the next 35-45\% 3-nerved. Floret very narrow elliptic, 5-6.5 mm long (including callus). Lemma smooth, white to tawny at maturity, with long, soft, slightly spreading, white to yellow hairs, the upper overlapping the base of the awn, appearing to form a $2 \mathrm{~mm}$ coma, lobes absent. Callus straight, $1.3-1.4 \mathrm{~mm}$ long, sericeous with similar hairs to the lemma. Awn very slender, $0.15 \mathrm{~mm}$ wide near the base, $23-38 \mathrm{~mm}$ long, twice bent; column 7-12 mm long, $3-7 \mathrm{~mm}$ to the first bend, antrorsely scaberulous with hairs less than $0.1 \mathrm{~mm}$ long; bristle antrorsely scabrous. Palea acute, c. $0.5 \mathrm{~mm}$ shorter than the lemma, sericeous with long, soft hairs. Lodicules 2, membranous, abaxial, oblong, $1.5 \mathrm{~mm}$ long. Anthers not observed. Caryopsis not observed.

DistriBution: Islands and coast around the Shark Bay area of Western Australia.

The ms. name "S. peronensis" appears on some of our early determinavit slips on specimens of this species.

SEleCted SPECIMENS: Western Australia: Carnarvon: W. of White Beach, Dorre Island, Weston 10484, 13.8.1977 (PERTH); Dorre Island, Shark Bay, Royce 5909, 15.7.1959 (PERTH); Sandy Point, Dirk Hartog Island, $25^{\circ} 42^{\prime} \mathrm{S}, 113^{\circ} 03^{\prime} \mathrm{E}$, George 11536, 5.9.1972 (PERTH); Cape Ransonnet,

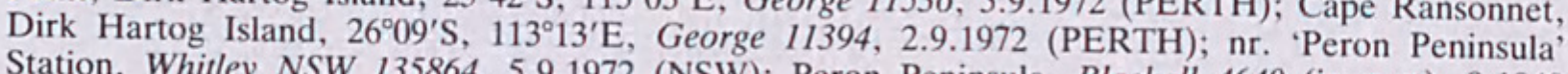
Station, Whitley NSW 135864, 5.9.1972 (NSW); Peron Peninsula, Blackall 4640 (in part), 9.1940 (PERTH); Mt Elliot, Carrarang, Beard 7073, 16.10.1974 (PERTH). Irwin: N. to Houtman Abrolhos, Storr 2225, 6.9.1959 (PERTH).

\section{Stipa curticoma $J$. Vickery, Telopea 2(1): 11 (1980).} Holotype: South Australia: Mt Lofty Ranges, $3 \mathrm{~km} \mathrm{S.} \mathrm{of} \mathrm{Mt} \mathrm{Barker,} \mathrm{M.D.} \mathrm{Crisp} 884$,
13.10.1974 (CBG 058899).

Caespitose perennial to 1.2 metres high with a basal tuft of leaves c. one third the height. Culms usually geniculate at the base, terete, 2-3 mm wide near the base, scarcely compressible, slightly ribbed, glabrous except puberulous at the very base and just below the nodes; nodes $3-4$, exserted, sericeous, 25-40\% broader than adjacent internodes. Leaf sheaths at first tightly enveloping the culm, later becoming free, 4-6 mm wide, $1 / 2-2 / 3$ the length of the internodes; basal sheaths puberulous, especially just below the orifice, to almost glabrous; upper sheaths minutely scaberulous or glabrous, occasionally puberulous near truncate, coriaceous, margin ciliate or, on upper sheaths, glabrous. Ligule truncate, coriaceous, $0.5-1.5 \mathrm{~mm}$ long, ciliate, abaxial surface puberulous; auricles usually thickened and spreading, with hair tufts to $1 \mathrm{~mm}$ long. Leaf blade flat or weakly rolled (those of the basal tuft more tightly so), 3-5 mm wide, to $30 \mathrm{~cm}$ long; abaxial surface slightly ribbed, glabrous or densely scabrous with minute hairs, with occasional, scattered, moderately long, rigid, straight 
hairs or strong hooks; adaxial surface ribbed, minutely scaberulous, sometimes with scattered longer hairs; margins similar to abaxial surface or with occasional long, stiff, scabrous hairs. Panicle $15-30 \mathrm{~cm}$ long, exserted, with distant fascicles of unequal, few- to many-flowered, compound branches, usually spreading, 5-7 cm wide (excluding awns); axis terete to flattened upwards, glabrous to scabrous with glistening hairs upwards; branches to $10 \mathrm{~cm}$ long, flattened to angular, the edges scabrous with glistening hairs; pedicels 4-16 mm long, flattened to angular, scabrous with glistening hairs on the edges. Spikelets 12-16 (-18) $\mathrm{mm}$ long (excluding awn), gaping slightly at first, but widely after floret disarticulation. Glumes unequal, acuminate to acute-oblong, firm and green at the base, membranous and purple-tinged across the centre, hyaline and occasionally torn at the tip, scaberulous on the nerves only, or overall, slender chlorenchyma bands associated with the nerves; lower glume 12-16 $(-18) \mathrm{mm}$ long, the lower $60-75 \%$ 3-nerved; upper glume 9-14 mm long, lower $30 \%$ 5nerved, next $30-45 \%$ 3-nerved. Floret oblong-cylindical with a well defined neck, (5.8-) 6.5-8 $\mathrm{mm}$ long (including callus). Lemma very slightly gibbous at maturity, reddish brown to almost black at maturity, the central nerve slightly thickened, the surface granular, with sparse spreading white hairs glistening at maturity, sparser towards the apex; lobes 2, $0.1(-0.5) \mathrm{mm}$ long; coma $0.5-1.0 \mathrm{~mm}$ long but usually with a few hairs to $0.5 \mathrm{~mm}$ longer. Callus $1.5-2.5 \mathrm{~mm}$ long, sharp, sturdy and curved, sericeous with hairs yellowing at maturity. Awn $45-65 \mathrm{~mm}$ long, twice bent, $0.25-0.35 \mathrm{~mm}$ wide near the base; column 18-25 mm long, 9-11 mm to the first and stronger bend, densely pubescent with spreading glistening hairs $0.25-0.5 \mathrm{~mm}$ long; bristle scabrous. Palea \pm equal to the lemma to shorter by $0.3 \mathrm{~mm}$, broadly acute to acuminate, finely granular down the back, hyaline on the margins to membranous at the tip with sparse hairs down the centre and occasionally at the tip. Lodicules 3, membranous; 2 abaxial $1.3-2.0 \mathrm{~mm}$ long, oblong to narrow-cuneate; paleal $1-1.3 \mathrm{~mm}$ long, oblong to narrow-triangular. Anthers $3-3.5 \mathrm{~mm}$ long, penicillate. Caryopsis c. $4 \mathrm{~mm}$ long; embryo $30 \%$ the length; hilum $90 \%$ the length.

Distribution: Heavier soils of the Lofty regions of southern South Australia, Kangaroo Island and extending into the Grampians, Victoria.

Selected Specimens: Victoria: Region C: $4.7 \mathrm{~km}$ from Dimboola, Nhill road, Canning 2972 , 11.11.1969 (NSW); Grampians, Mt. Arapiles, Beauglehole 29667, 20.11.1968 (ACB). Region N: Melbourne, Smith 69/43, 30.10.1969 (MEL).

South Australia: Eyre Peninsula: Claremont Hill, no collector, 11.1925 (ADW 278 in part). Northern Lofty: Clare, Black, 8.11.1920 (AD 97420231). Yorke Peninsula: Point Davenport, Symon $11885,4.11 .1979$ (ADW). Southern Lofty: Black Hill, c. $12 \mathrm{~km}$ ENE. of Adelaide, Czornij 253, 21.11.1968 (AD); Modbury, c. $15 \mathrm{~km}$ NE. of Adelaide, Spooner 1274, 24.10.1970 (AD); Beefacres, between Hope Valley Reservoir \& Torrens Creek, Spooner 2718, 21.12.1973 (AD); Hope Valley, c. $10 \mathrm{~km} \mathrm{NE}$. of Adelaide, Cleland, 15.11 .1947 (AD); near Highbury Hotel, c. $13 \mathrm{~km}$ NE. of Adelaide, Kraehenbuehl 824, 22.10.1942 (AD); Highbury, Sassafras Drive, c. $15 \mathrm{~km}$ NE. of Adelaide, Spooner 1318, 12.10.1970 (AD); National Park, c. $6 \mathrm{~km}$ SE. of Adelaide, Cleland, 17.12.1939 (AD); Adelaide Hills Belair, Hilton, 13.10.1944 (ADW 44019); Adelaide Plains near Plympton, c. $5 \mathrm{~km} \mathrm{SW}$. of Adelaide, Smith 1224, 19.10.1968 (AD); Waite Institute, Eardley, 10.11.1931 (ADW 251); Adelaide foothills, Netherby, Hilton, 19.9.1944 (ADW 44105); Coxs Scrub National Park, c. 55 km SSE. of Adelaide, Crisp 121, 30.10.1971 (AD). Kangaroo Island: Kingscote, Cleland, 23.11.1945 (AD). South-eastern: Encounter Bay, Halls Creek, c. $5 \mathrm{~km} \mathrm{~W}$. of Victor Harbour, Cleland, 5.1.1940 (AD).

In habit and general appearance S. curticoma resembles some South Australian specimens of $S$. blackii but differs in that the coma of hairs at the apex of the lemma is very short. It differs from $S$. eremophila in its taller habit, essentially flat leaf blades, mostly white (only tardily fulvous) hairs on the 
lemma, much shorter bristle and usually broader glumes; from $S$. flavescens in its broader glumes, stouter awn with the column stiffly scabrous-pubescent (not very finely pubescent to pilose), and shows no particular preference for maritime or estuarine habitats; from $S$. aristiglumis in its longer glumes, longer lemma with a longer and almost straight callus, and appears to occur in quite different edaphic and geographic situations; from $S$. gibbosa in its longer and more or less evenly fusiform lemma, usually longer awn, and usually narrower palea with a band of hairs down the middle of the back.

Stipa densiflora Hughes, Kew Bull. 1921: 18, fig. 20, (1921); non Smirn. (1929); Vickery, Contrib. N.S.W. Natl. Herb. 2: 78 (1953); Burbidge \& Gray, Fl. Austral. Cap. Terr.: 53 (1970).

Holotype: Central Victoria, Etheridge 1865 (K!). The Type sheet consists of a packet containing a small fragment of panicle with spikelets, and a small drawing by Hughes of a spikelet and a lemma; also a drawing of a panicle subtended by two uppermost leaves with no indication of what specimen it represents.

SYNONYM: S. congesta Summerhayes \& Hubbard, Kew Bull. 1927: 362 (1927). HolOTYPE: SOUTH Australia: Morialta, Cleland 33, 2.10.1925 (K!, isotype at AD and fragment at MEL).

Caespitose perennial c. $0.5-1.5$ metres high, not rhizomatous, with a basal tuft of leaves one third to half the height. Culms erect, slightly geniculate at the base, terete, not compressible, slightly ribbed, pubescent with hairs $0.1-0.7 \mathrm{~mm}$ long becoming minute upwards; nodes $2-4$, exserted, densely sericeous with hairs to $0.5 \mathrm{~mm}$ long, to $50 \%$ wider than the adjacent internodes. Leaf sheaths not inflated; basal sheath $0.5-1.5 \mathrm{~cm}$ wide, slightly ribbed, pubescent with hairs to $0.4 \mathrm{~mm}$ long to glabrous; inner margin glabrous; outer margin ciliate with hairs minute- $-0.6 \mathrm{~mm}$ long; upper sheath $5-10 \mathrm{~mm}$ wide, moderately ribbed, pubescent down the centre with hairs minute- $-0.5 \mathrm{~mm}$ long; margins scaberulous with hairs minute $-0.1 \mathrm{~mm}$ long or scabrous with minute tubercules; inner margin glabrous or ciliate with hairs $0.1-0.2 \mathrm{~mm}$ long, outer margin ciliate with hairs $0.2-0.7 \mathrm{~mm}$ long; collar with hairs $0.1-0.7 \mathrm{~mm}$ long. Ligule truncate to shortly laciniate, (0.1-) 1-4 mm long, ciliate with hairs $0.1-0.5 \mathrm{~mm}$ long; abaxial surface sericeous with hairs $0.1-0.5 \mathrm{~mm}$ long; auricles, when present, thickened, 5-15 mm long, glabrous. Leaf blade weakly rolled, linear, $1.5-4.5 \mathrm{~mm}$ wide, $15-45 \mathrm{~cm}$ long; abaxial surface moderately ribbed, the surface scabrous with minute tubercles, or sparsely pubescent with hairs to $0.5 \mathrm{~mm}$ long; adaxial surface strongly ribbed, pubescent with hairs $0.1-0.2(-0.5) \mathrm{mm}$ long; margins glabrous or similar to adaxial surface. Panicle $10-30 \mathrm{~cm}$ long, exserted, moderately dense with distant fascicles of unequal, few-flowered, compound or simple branches, contracted (although spreading at anthesis), $2-5 \mathrm{~cm}$ wide (excluding awns); axis terete (or angled), scabrous with hairs minute- $0.1 \mathrm{~mm}$ long; branches 2-8 cm long, angled, pubescent to scabrous with hairs minute- $0.2 \mathrm{~mm}$ long. Spikelets $13-18 \mathrm{~mm}$ long (excluding awn), gaping. Glumes unequal to equal, acuminate; lower glume 13-18 mm long, sericeous with hairs minute- $0.5 \mathrm{~mm}$ long, lower (35-) 40-55\% (5-) 3-nerved, upper $45-60(-65) \%$ (3-) 2-1-nerved; upper glume $12-16 \mathrm{~mm}$ long, sericeous with hairs minute- $0.1 \mathrm{~mm}$ long, lower 15-35 (-45)\% (5-) 3-nerved, upper 45-60 (-65)\% (3-) 2-1-nerved. Floret cylindrical, 5.5-7 $\mathrm{mm}$ long (including callus), without a neck. Lemma surface scabrous, especially at the apex, sericeous with white hairs $0.3-0.6 \mathrm{~mm}$ long; lobes and coma absent. Callus $1.2-1.8 \mathrm{~mm}$ long, weakly bent at the tip, densely sericeous with hairs $0.2-1 \mathrm{~mm}$ long. Awn $3.5-4.5 \mathrm{~cm}$ long, strongly twice bent, $0.2-0.3 \mathrm{~mm}$ wide near the base; column $13-20 \mathrm{~mm}$ long, 
$10-13 \mathrm{~mm}$ to the first bend, pubescent to plumose with hairs $0.5-1 \mathrm{~mm}$ long; bristle scabrous with hairs minute $-0.2 \mathrm{~mm}$ long. Palea \pm equal to the lemma, acute, scabrous, glabrous and smooth on the edges, sericeous with hairs 0.3-0.6 mm long. Lodicules $3 ; 2$ abaxial, membranous, obtuse, $1.5-2 \mathrm{~mm}$ long; paleal acute, $1.6-1.8 \mathrm{~mm}$ long. Anthers $2-3 \mathrm{~mm}$ long, not penicillate. Caryopsis 3-3.5 mm long; embryo $20-25 \%$ the length; hilum $70-85 \%$ the length.

Distribution: Tablelands and western slopes of the Great Dividing Range, from southern Queensland into Victoria and higher areas of southern South Australia, usually on low fertility soils.

Selected Specimens: QueEnSLAND: Darling Downs: Wallangarra, Hilton NSW 116904, 14.1.1945 (AD, NSW); Wyberba, Blake 4632, 23.1.1933 (NSW).

NEw SOUTH WaLEs: Central Coast: The Oaks, Orangeville road, McBarron 13704, 12.1966 (NSW, CANB). South Coast: Cobargo, District Agronomist Bega, NSW 115837, 10.1970 (NSW); Wolumba, Blacke NSW 116248, 23.10.1974 (NSW). Northern Tablelands: head of the Gwydir (River), no collector (MEL 60916); Parlour Mountains, Booralong, c. 18 miles [29 km] SW. of Guyra, McKie 2407, 27.12.1943 (BRI); 5.5 miles [9 km] N. of Armidale on road to Guyra, Jessup \& Gray NSW 115838, 1.1953 (NSW). Central Tablelands: Ilford, Suttor NSW 115839, 12.1963 (NSW); Sodwalls, Dellow NSW 115840, 11.1971 (NSW); Joadja Valley, 12 miles [19 km] W. of Bowral, Rodway NSW $115841,3.1956$ (NSW); Berrima, Calvert (MEL). Southern Tablelands: Goulburn, Vickery NSW $18038,11.1931$ (NSW); Cullerin Range, $4.2 \mathrm{~km}$ N. of Cullerin, Crisp 2319 \& Telford, 19.11.1976 (CBG); Yass district, Pastures Protection Board NSW 15847, 12.1942 (NSW); Bungonia Gorge, S. of Marulan, Pullen 4163, 11.1966 (NSW, CANB); c. 4 miles [22 km] from Tarago towards Braidwood, Wheeler 16, 23.11.1972 (CBG); 8 miles [13 km] NE. of Bungendore, Gunning Shire, Story 7888, 16.4.1967 (CANB); Black Mt, Canberra (A.C.T.), Pullen 19, 12.1956 (NSW, CANB, AD); near Doughboy Creek, Goulburn to Braidwood road, Pullen 2059, 8.12.1959 (CANB); Mt Majura (A.C.T.), Burbidge 1804, 6.1.1948 (CANB); 6 miles [10 km] from Canberra on Federal Highway to Goulburn, Burbidge 1803, 6.1.1948 (CANB); Canberra Botanic Gardens, Beeton CBG 044493, 1.1972 (CBG); near Tharwa (A.C.T.), Blake 7547, 2.1935 (NSW); Cooma, Mueller NSW 115845, 12.1952 (NSW). North Western Slopes: c. 20 miles [32 km] NNE. of Ashford on road to Emmaville, Morrow 96, 22.3.1968 (NSW); Inverell, Thomas NSW 115868, 1.1912 (NSW); Barraba, Rupp NSW 115866, 11.1913 (NSW); Tamworth district, Boyle NSW 115865, 11.1947 (NSW); Coonabarabran, McDonald NSW 115867, 10.1903 (NSW). Central Western Slopes: Cobbora, MacCulloch NSW 15869, 11.1969 (NSW); 8 miles [13 km] NE. of Dubbo towards Mendooran, Coveny 2483, 26.11.1969 (NSW); Mudgee, Wools, s.d. (MEL 60923); Reefton, Nixon NSW 115879 (NSW); Harvey Ranges, Peak Hill, no collector, 11.1905 (NSW 115880); Parkes, Perry NSW 115876, 11.1962 (NSW); Rankin Springs, Wallin NSW 115877, 10.1956 (NSW); Grenfell, Hill NSW 115875, 11.1962 (NSW): Ariah to Coolamon road, Southwood NSW 115871, 10.1963 (NSW); Ardlethan, Cambage NSW 115885, 10.1916 (NSW, CANB); Temora, Dwyer NSW 115872, 11.1916 (NSW); $20 \mathrm{~km} \mathrm{W.} \mathrm{of}$ Temora, Crisp 1658, 20.11.1975 (NSW, CBG); Narraburra-Trungle Hills, Temora, Dwyer NSW $115883,10.1915$ (NSW). South Western Slopes: Wagga, Crisp 1825, 27.11.1975 (CBG); The Rock, Constable 5174, 21.10.1964 (NSW, CANB, BRI); Milbrulong, Newman NSW 115870, 11.1955 (NSW); Tumut-Tumbarumba-Holbrook district, Morland NSW 115874, 1.1948 (NSW); Walbundry-Albury, Moore M492, 7.12.1946 (CANB). North Western Plains: Coolabah, Maiden \& Boorman NSW 115888, 8.1910 (NSW). South Western Plains: Monia Gap, Constable. NSW 4604, 10.1947 (NSW); Milby Hill, Condobolin, Cunningham NSW 115886, 11.1972 (NSW); Boppy Mt, Boorman NSW 115887, 7.1903 (NSW); Mt Binya, c. 25 km ENE. of Griffith, Crisp 1466, 12.11.1975 (NSW, CBG); Griffith, McKie NSW 116905, 27.10.1939 (NSW).

VICTORIA: Region J: Mt Hamilton, Wulgulmerang, East Gippsland, Beauglehole 36115, 16.1.1971 (NSW). Region K: Brisbane Range, Staughton Vale (c. $50 \mathrm{~km}$ SE. of Ballarat), Cleland, 11.1923 (AD). Region M: Eaglehawk, Canning 3010, 14.11.1969 (CBG); Longwood, Stewart, 10.1950 (BRI); Mt McIvor, Stuart, s.d. (MEL.). Region N: Bairnsdale district, Hart (MEL); Kew (River Yarra), Dakin, 2.1934 (MEL). Region R: c. 1.25 miles [2 km] E. of Mt Pilot, c. 6 miles $[10 \mathrm{~km}] \mathrm{N}$. of Beechworth, Beauglehole 43598, 23.11.1973 (NSW); Warby Range, near Wangaratta, Canning 3214, 29.11.1972 (CBG); Beechworth Gorge, Canning 392, 30.10.1967 (CBG); Mt Stanley, McBarron 2914, 3.1.1949 (NSW). Region S: Valencia Creek road, 15.5 miles [24.8 km] SE. of Mt Wellington, Beauglehole 43434, 30.10.1973 (NSW). Region V: Mitta Mitta, Black, 5.11.1939 (CANB 9777). Region W: Rocky Knob near Bridle Creek, Suggan Buggan, Beauglehole 33249, Finck \& Rogers, 6.1.1970 (NSW). Region Z: Upper Genoa River, Beauglehole 35010 and Rogers, 30.11 .1970 (NSW).

South Australia: Flinders Ranges: Alligator Creek, Ising, 23.10.1928 (AD 966090382). Eastern: Morialpa [as Morialta], Vickery NSW 116246, 116247, 11.1938 (NSW). Southern Lofty: Barossa 
Valley, Hilton 195 (ADW); Torrens Gorge, East, Spooner 420, 22.10.1969 (AD); Mt Barker, Cleland, 4.12.1943 (AD).

S. densiflora has been included in S. semibarbata by many authors including Maiden, Manual Grasses N.S.W.: 115 (1898); Willis, Handb. Pl. Victoria 1: 184 (1962), edn 2: 184 (1970).

Stipa dongicola J. Vickery, S. W. L. Jacobs \& J. Everett, sp. nov.

S. curticomae affinis sed columna villosa, spicula omnibus partibus minore, palea glabra, nodis conspicuis glabrisque differt.

Holotype: Western Australia: Blackoak Donga, 'Kanandah' Station, approx. $20 \mathrm{~km} \mathrm{~N}$. of Naretha. Donga. M. G. Brooker 160, 16.9.1974 (CANB 249733; isotype NSW).

Caespitose perennial to c. 1 metre tall, with few, conspicuously extravaginal shoots, and a very short rhizome. Culms $1.3-2.3 \mathrm{~mm}$ wide, rigid, terete, finely ribbed, minutely retrorsely scaberulous-puberulous beween the ribs, glabrous upwards; nodes 3-4, glabrous, usually thickened, to $60 \%$ broader than adjacent internodes, exserted. Leaf sheaths narrow, loose, smooth and glabrous, or the lowermost scaberulous and hirsute; the orifice and the collar hairier than the sheath; outer margin similar to adjacent surfaces. Ligule obtuse to truncate, coriaceous, $0.8-1.5 \mathrm{~mm}$ long, densely sericeous on the back. Leaf blades linear, to $35 \mathrm{~cm}$ long, c. $3-4 \mathrm{~mm}$ wide, usually expanded and flexuose or, if inrolled, then erect; abaxial surface sparsely hirsute to scabrous with dense short hairs; adaxial surface sparsely to densely pubescent, scaberulous with sparse minute hairs. Panicle with distant fascicles of unequal compound branches, contracted to spreading at length, exserted early, c. 14-30 cm long, 1-6 cm wide (excluding awns); axis flattened, scabrous to scaberulous with dense short hairs; branches $2-5 \mathrm{~cm}$ long, pedicels $2-11 \mathrm{~mm}$ long, both with similar indumentum to the axis. Spikelets only slightly gaping even after floret disarticulation, 7-12 mm long (excluding awn). Glumes subequal, broad, acuminate, firm and usually purple in the lower half, hyaline and easily eroded at the tips; lower glume 7-12 mm long, lower 75\% 3-nerved; upper glume 8-11 mm long, lower $30 \% 5$-nerved, the next $45 \%$ 3-nerved. Floret 5-6.5 mm long (including callus), oblong-cylindrical with a well defined neck showing 3 thickened nerves. Lemma scabrous, especially at the neck, with antrorsely hooked tubercles, reddish brown at maturity, with slightly spreading white to yellow-orange hairs sparser just below the apex, and with a sparse coma to $0.7 \mathrm{~mm}$ long mainly in two tufts; lobes absent or minute. Callus $1.5-2 \mathrm{~mm}$ long, slightly blunt, sericeous with hairs slightly darker than those on the lemma. Awn c. $0.3 \mathrm{~mm}$ wide, $30-40 \mathrm{~mm}$ long, twice bent, the first bend less developed; column c. $15 \mathrm{~mm}$ long, the first section c. $10 \mathrm{~mm}$ long, villous with hairs $0.5-1.5 \mathrm{~mm}$ long, the second section scaberulous; bristle scabrous with short dense hairs. Palea subsequal to the lemma, broadly obtuse, glabrous, granular down the back, the margins hyaline. Lodicules 3, membranous; 2 abaxial broad-cuneate, c. $0.6 \mathrm{~mm}$ long; paleal acute, c. $0.4 \mathrm{~mm}$ long. Anthers c. $3.5 \mathrm{~mm}$ long with sparse tufts c. $0.25 \mathrm{~mm}$ long at the tip. Caryopsis slightly gibbous, $3-3.5 \mathrm{~mm}$ long; the hilum $75 \%$ the length, the embryo $35 \%$ the length.

SPECIMENS EXAmined: Western AuSTRAlia: Eucla: 60 miles [96 km] N. of Loongana, Mitchell 86 , 5.10.1974 (PERTH, NSW); 50 miles [80 km] NNE. of Rawlinna, Brooker 170, 5.9.1974 (CANB, NSW); $50 \mathrm{~km} \mathrm{~N}$. of Rawlinna, Brooker 3633, 4.6.1971 (PERTH); Blackoak Donga, c. $20 \mathrm{~km} \mathrm{N.} \mathrm{of}$ Naretha, Brooker 160, 16.9.1974 (CANB, NSW); CSIRO property, Rawlinna, Goodall 2980 , 20.6.1966 (PERTH); $30 \mathrm{~km} \mathrm{~S}$. of Rawlinna, $125^{\circ} 28^{\prime} \mathrm{E}, 31^{\circ} 11^{\prime} \mathrm{S}$, Chinnock 1157, 1.9.1973 (AD); $62 \mathrm{~km} \mathrm{~S}$. of Rawlinna, Cocklebiddy road, George 11877, 12.7.1974 (PERTH, NSW). 
The specific epithet refers to the habitat common to most of the specimens on the Nullarbor Plain, i.e. dongas (or gilgais).

Like $S$. curticoma but differing in the villous column, the overall smaller dimensions of the spikelet, the glabrous palea and in the conspicuous, glabrous nodes. Differs from $S$. blackii in its shorter coma and villous column.

Stipa drummondii Steudel, Syn. Pl. Glum. 1: 128 (1854); Bentham, Fl. Austral. 7: 567 (1878); Hughes, Kew Bull. 1921: 16 (1921), ibid. 1922: 17 (1922); Black, Fl. S. Austral. edn 2: 88, fig. 108 (1974); Gardner, Fl. W. Austral. 1, Gram.: 176 (1952); Willis, Handb. Pl. Victoria 1: 186 (1962), edn 2: 186 (1970).

Holotype: cited as 'Australasia. Drummond, Coll. IV, $n$ r. 578'. Drummond's collecting number is believed to have been misunderstood by Steudel. A specimen in Steudel's herbarium (P!) bears Drummond's original collecting ticket numbered 378, and has a label in Steudel's handwriting 'Stipa Drummondii. Steud. quo ad descriptionem a S. campylachne Nees et omnibus (...) usque e N. Holl. descriptis speciebus diversa'. This we have taken as the Holotype; duplicates of the Type number at MEL (MEL 59909), PERTH and K (labelled Drummond 378, 4th collection, as cited by Bentham). An un-numbered Drummond specimen in NSW (NSW 16249) also matches the Type numbers at MEL and $K$.

SYNONYMS: S. luehmannii Reader, Victorian Naturalist 16: 158 (1900); Hughes, Kew Bull. 1921: 28 (1921). HoloYPe: Victoria: Sandy Desert, Lowan, 30.11.1898, F.M. Reader (MEL 59939).

S. horrifolia J. Black, Trans. \& Proc. Roy. Soc. S. Austral. 44: 191 (1920). LeCTOTYPE. here designated: Nullarbor Plain, R.S. Rogers, 4.1911 (AD 97424081; isolectotypes MEL 59940, NSW 116254).

PosSIBLE SYNONYMS: S. scabra var. subtricha Reader, Victorian Naturalist 17: 156 (1901). HolOTYPE: cited as 'Jan. 1899. Sandy regions, Lowan, F.M. Reader'. We have not found this specimen in MEL, where Reader's collections are now housed. There are, however, two other specimens from the same area (MEL 60784 and 60885) named as such, MEL 60784 in Reader's handwriting. Both these specimens are $S$. drummondii.

S. scabra var. auriculata J. Black, Fl. S. Austral. 1: 67 (1922). HolotYPE: cited as 'Dry Districts'. We have not been able to find a specimen so labelled but in $\mathrm{K}$ there is a specimen from Laura, 8.10.1916, labelled as S. scabra var. auriculata in J.M. Black's handwriting. This specimen is S. drummondii.

Caespitose perennial to 1 metre high with a basal leaf tuft often less than one third the height. Culms erect or geniculate, compressible, terete, $2-3 \mathrm{~mm}$ wide near the base, slightly ribbed, densely puberulous or scaberulous to almost glabrous, or tomentose especially just below the nodes; nodes $2-3$, rarely exserted, to $25 \%$ broader than adjacent internodes, almost glabrous or sericeous. Leaf sheaths inflated, slightly ribbed, scaberulous, hirsute, with longer hairs around the collar; uppermost sheaths glabrous; inner margin glabrous; outer margin glabrous or occasionally ciliate just below the orifice. Ligule thinly coriaceous, $0.4-0.8 \mathrm{~mm}$ long or continuous with the sheath margins and to 1.5 $(-4) \mathrm{mm}$ long, ovate to irregularly truncate, ciliate; abaxial surface sparsely pubescent; auricles tufted. Leaf blades to $20 \mathrm{~cm}$ long, 2-6 mm wide, mainly erect, occasionally flexuose, usually expanded with incurved margins or involute; abaxial surface scarcely ribbed, scabrous and hirsute; adaxial surface deeply ribbed, scabrous and pubescent or hirsute. Margins similar to abaxial surface. Panicle to $40 \mathrm{~cm}$ long, 4-10 (-16) cm wide (excluding awns), exserted, spreading, dense with moderately distant fascicles of numerous many-flowered branches; axis terete, pubescent and/or scaberulous; branches to $13 \mathrm{~cm}$ long \pm terete, pubescent or scaberulous; pedicels to $20 \mathrm{~mm}$ long, \pm terete, pubescent or scaberulous. Spikelets(7-) 8-12 mm long (excluding awn), gaping. Glumes 
unequal, acuminate or acute, the tips easily torn, often purple-tinged, usually associated with diffuse chlorenchyma bands; lower glume (7-) 8-12 mm long, membranous and translucent, the lower $25 \%$ obscurely 3-5-nerved; upper glume (6-) 7-11 mm long, membranous and translucent at the tip, firm and chaffy at the base, the lower $40-60 \%$ 5-nerved, the next $25 \%$ 3-nerved. Floret linear to slightly turbinate to fusiform, 4-6 (-7) $\mathrm{mm}$ long (including callus). Lemma very finely granular, except tuberculate over the apex of the midvein, red to blackbrown at maturity, the midvein slightly paler and thickened; hairs white, erect and slightly spreading, sparse especially at the apex; coma obscure, of few hairs to $0.5 \mathrm{~mm}$ long, or absent; $1-2$ lobes to $0.2 \mathrm{~mm}$ long. Callus $1.5-2.5 \mathrm{~mm}$ long, fine and straight, sericeous with dense hairs similar to those of the lemma. Awn (40-) $60-90 \mathrm{~mm}$ long, $0.2-0.3 \mathrm{~mm}$ wide near the base, falcate; column (11-) 14-18 (-21) $\mathrm{mm}$ long, $10-19 \mathrm{~mm}$ to the end of the straight portion, densely pubescent or villous with spreading hairs $0.3-0.8(-1.5) \mathrm{mm}$ long; bristle scaberulous. Palea $0.3-0.5 \mathrm{~mm}$ shorter than the lemma, obtuse, coriaceous down the centre with few hairs at the base, margins membranous and glabrous, tip membranous, glabrous or ciliate. Lodicules 2, membranous, abaxial, $0.8-1.8 \mathrm{~mm}$ long, linear-spathulate. Anthers $1.8-3 \mathrm{~mm}$ long, often lightly pencillate. Caryopsis 3-5 mm long; embryo $40 \%$ the length; hilum $50-65 \%$ the length.

DiSTRIBUTION: Sandy areas of the western plains of New South Wales and Victoria, extending across South Australia into the southern regions of Western Australia.

Selected Specimens: New South Wales: North Western Slopes: Liverpool Plains, no collector NSW 16259, 2.1880 (NSW). North Western Plains: Bungunyah, Henderson 335, 27.10.1947 (NSW); Coolabah, Peacock NSW 116877, 10.1900 (NSW). South Western Plains: Griffith, Vickery NSW 10186, 19.10.1949 (NSW); W. of Balranald, Henderson 337/2, 5.10.1947 (NSW); $30 \mathrm{~km}$ NNW. of Balranald, Crisp $1760,29.11 .1975$ (NSW, CBG); 5 miles [8 km] W. of Stony Crossing, Henderson $337 / 1,13.10 .1947$ (NSW); S. of Tueloga, Henderson 337/4, 23.9.1947 (NSW); Cunninyeuk (S. of Balranald), Henderson 174, 8.10.1946 (NSW); Coobool Sandhill, Henderson 335/2, 6.10.1947 (NSW); Barham, Vickery NSW 10195, 13.10.1949 (NSW); Barooga, Vickery NSW 116268, 11.10.1949 (NSW). North Far Western Plains: c. 150 km NW. of Louth, Moore 5050, 25.4.1967 (CANB). South Far Western Plains: c. $10 \mathrm{~km}$ before Menindee, Richley M5, 5.9.1973 (AD); Ivanhoe, Leigh NSW 116293, 19.10.1964 (NSW); 60 miles [96 km] S. of Wilcannia, Cobar road, Martensz 1513, 2.1968 (CANB).

VictoriA: Region A: Northern Plains, $30 \mathrm{~km}$ SSW. of Mildura, $9 \mathrm{~km} \mathrm{~S}$. of Benetook along Meridian road, Crisp 3292, 9.10.1977 (CBG); Mildura, Williamson, 28.10.1928 (MEL); 41.5 miles [66.4 km] from Mildura towards Renmark (S.A.) along Sturt Highway, Canning NSW 116266 , 27.8.1968 (NSW; BRI dupl. of CBG); Redcliffs, Beauglehole 7550, 18.9.1964 (NSW); Hattah Lakes National Park, Phillips CBG 027109, 14.11.1962 (CBG). Region B: Murrayville, Williamson, $28.10 .1928(\mathrm{MEL}) ; 4$ miles [6 km] N. of Tempy, Henshall NSW 116676, 20.9.1969 (NSW); Wyperfeld National Park, Beauglehole 29231, 29178 \& Finck, 10.10.1968 (NSW, MEL). Region C: Little Desert, Reader, 19.11.1899 (MEL); Sandy Desert, no collector (MEL 59908). Region G: Wathe Wildlife Reserve, 13 km WNW. of Gama, Beauglehole 56943, 23.10.1977 (MEL). Region H: Boort, Purdie, 1894 (MEL 59893); Borung, Reader, 23.10.1904 (AD; MEL 59895). Region L: Gunbower, Curtis, (MEL 59896). Region M: Kamarooka, N. of Bendigo, Morris, 10.1947 (MEL). Region Q: Cobram, Moore M977, 20.10.1948 (CANB).

SOUTH Australia: Nullarbor: Colona to Ooldea road, Cleland, 8.10.1954 (AD, ADW); Nullarbor Plain, $1.6 \mathrm{~km}$ W. of Ivy Tanks, Beauglehole 49476, 31.8.1974 (CANB); 'Nullarbor' Station, Black NSW 116255, 6.1911 (NSW); 5 km E. of 'Koonalda' Homestead, Chinnock 1191, 21.9.1973 (AD, NSW); Tallowan Tank, Cleland, 17.10.1953 (AD); 'Yalata' Homestead, Cleland, 18.10.1953 (AD). Flinders Ranges: Greenhill road, Cleland, 9.10.1948 (AD); Parachilna Gorge, Everett 298 \& Jacobs, 18.9.1981 (NSW); Deep Creek, 5 miles [8 km] E. of Burra, Cleland, 24.8.1941 (ADW); Waterfall Creek near Baroota, Kraehenbuehl 195, 18.9.1960 (AD); Tarcowie Common, $16 \mathrm{~km} \mathrm{W.} \mathrm{of}$ Peterbrough, Crisp 590, 9.9.1973 (CBG). Eastern: $30 \mathrm{~km} \mathrm{~N}$. of Yunta, Crisp 588, 9.9.1973 (CBG). Eyre Peninsula: 49 miles [78 km] from Nundroo towards 'Nullarbor' Homestead, Canning NSW 116265, 116267, 3.9.1968 (CBG, NSW, BRI); Kooniba, Cleland, 6.10.1954 (AD); Ceduna, Canning 
CBG 042997, 1.9.1968 (CBG, NSW); near Yardea, Cleland, 14.10.1954 (ADW); 24.9 miles [40 km] from Iron Knob towards Port Augusta, Canning CBG 043034, 28.8.1968 (CBG, BRI); Minnipa, Black, 9.1940 (AD); Minnipa-Wudinna, French 8, 10.1954 (ADW, NSW); Kimba, French 2. 2.10.1954 (ADW); 9 miles [14 km] from Cleve towards Lock, Phillips 463, 20.9.1965 (CBG); near Midgee Rocks on road to Mitchelville, NE. of Cowell, Pearce NSW 116956, 2.1965 (NSW, dup. of ADW); nr. Wild Horse Plain, near Lorne, Blake 16844, 28.8.1946 (BRI); $5.5 \mathrm{~km} \mathrm{S.} \mathrm{of} \mathrm{Cowell}$ towards Whyalla, Tindale 450, 12.9.1970 (NSW); Verran Hill, Hincks National Park, Alcock 2177. 6.10.1968 (AD); Yelanna, 10 miles [16 km] N. of Cummins, Hilton NSW 116289, 20.12.1945 (ADW, NSW). Northern Lofty: between Port Wakefield and Kulpara, Blaýlock 610, 30.9.1967 (AD); c. 1 mile [1.6 km] S. of Freeling, Kraehenbuehl 1541, 18.9.1965 (AD); Gladstone, Black, 23.10.1915 (AD); $4 \mathrm{~km} \mathrm{S.} \mathrm{of} \mathrm{Kupunda} \mathrm{on} \mathrm{Adelaide} \mathrm{road,} \mathrm{Monfries} \mathrm{NSW} \mathrm{11364,} \mathrm{20.10.1974} \mathrm{(ADW,} \mathrm{NSW).}$ Murray: $30 \mathrm{~km} \mathrm{~N}$. of Yunta, Crisp 588, 9.9.1973 (CBG); Morgan, Brummitt, 28.8.1894 (AD); Markaranka, Morgan, Symon 3561, 7.10.1965 (K ex ADW); 1 km downstream from Overland Corner Hotel, River Murray, Crisp 631, 7.10.1973 (CBG); Gerrard, near Berri, Cleland NSW $116274,28.8 .1946$ (AD, NSW); Loveday, Gauba CBG 003953, 14.12.1944 (CBG); between Renmark \& Blanchtown, Griffiths, 18.9.1969 (CANB); Swan Reach, Cleland, 8.5.1946 (AD); Alawoona, Cleland NSW 116256, 3.12.1913 (NSW, AD); 10 miles [16 km] E. of Mannum, Vickery NSW 2048, 24.8.1946 (NSW); Mannum, Blake 16842, 24.8.1946 (BRI); Chauncys Line near Monarto, Cleland SW 116273, 12.10.1938 (NSW, AD); Monarto City Centre, Symon 9068, 26.11.1974 (ADW, NSW); Kinchina, Cleland NSW 116261, 23.9.1922 (NSW, AD); Murray Bridge, Cleland, 14.10.1949 (AD); $5 \mathrm{~km} \mathrm{W.} \mathrm{of} \mathrm{Tailem} \mathrm{Bend,} \mathrm{Everett} 300$ \& Jacobs, 18.9.1981 (NSW); 45 miles [72 km] from Tailem Bend towards Lameroo, Phillips NSW 116714, 12.9.1973 (NSW, CBG); Cooke Plains, c. $40 \mathrm{~km}$ SSE. of Murray Bridge, Sharrad 148, 6.9.1959 (AD). Yorke Peninsula: South Kilkerran, Beck, 2.1942 (ADW); Port Broughton, Morris, 25.9.1947 (MEL); Tooligie district, French, 8.10.1954 (ADW); c. $8 \mathrm{~km}$ SSW. of Corny Point Lighthouse, Blaylock 106I, 13.10.1968 (AD); Corny Point, no collector, 10.12.1928 (ADW); 10 miles [16 km] from Edithburgh towards Moorie Point, Phillips 1247, 11.6.1971 (CBG). Southern Lofty: Roseworthy Agricultural College, Hilton NSW $116294,30.9 .1941$ (ADW, NSW); 1 mile [1.5 km] past Kangaroo Flat on the Mallalla road, Harris 34, 1.10.1954 (AD); Middle Beach, Noble 4I, 26.9.1972 (AD); Gawler Range near Artiming Dam N. of Yardea, Symon 8155, 3.10.1972 (ADW, NSW); Kambrai turnoff on Sedan road, Cleland, 14.9.1963 (AD); c. $1 \mathrm{~km} \mathrm{W.} \mathrm{of} \mathrm{Angle} \mathrm{Vale} \mathrm{road} \mathrm{and} \mathrm{western} \mathrm{side} \mathrm{of} \mathrm{Parafield}$ aerodrome, Kraehenbuehl 1452, 18.9 .1965 (AD); Brougham Place, North Adelaide, Black, 10.12.1920 (AD); Seaton Golf Links (c. 9 km WNW. of Adelaide), Smith 651, 13.10.1967 (AD); Outer Harbour (c. 17km NW. of Adelaide), Cleland, 22.10.1932 (AD); Menningham (Adelaide), Hilton NSW 116291, 8.9.1946 (ADW, NSW); coastal cliffs at Marino Rocks, Smith 692, 10.9.1967 (AD); Marino, Cleland, 15.9.1934 (AD); Hallett Cove, Cleland, 5.11.1926 (AD); Whittons Bluff at Port Noarlunga, Smith 438, 27.11.1967 (AD); Pedlars Beach, Cleland, 15.10.1927 (AD); North Willunga, Hilton NSW 116290, 20.10.1946 (ADW, NSW); Port Willunga, Cleland, 30.10.1928 (AD); Sellicks Beach, Black, 25.10.1940 (AD); cliffs at Aldinga Bay, Andrews, 2.11.1941 (AD); Goolwa, near Murray Mouth, Cleland, 8.1.1940 (AD). South-eastern: well c. $11 \mathrm{~km}$ from Meningee, Cleland, 15.10.1955 (AD); 1 mile [1.5 km] E. of Tintinara, Hilton, 11.10.1963 (ADW); Kingston Park, Eardley, 20.9.1936 (ADW).

Western Australia: Eucla: 'Mundrabilla' Station, Coles Bros., 28.7.1930 (ADW); 45 miles [72 km] W. of Eucla, Phillips NSW 116250, 8.9.1962 (NSW, dupl. of CBG); pediment of Hampton Range, Eucla, Noble 13, 8.8.1973 (NSW); Roe Plain S. of 'Mundrabilla', Mitchell 35, 6.8.1974 (PERTH). Coolgardie: Frasers Range, no collector (MEL 59907); 7 km NNE. of Norseman, Crisp 5951, Taylor \& Jackson, 19.9.1979 (CBG). Roe: Western margin of Lake King, Saffrey 1209. 29.9.1970 (PERTH). Eyre: Israelite Bay, Brookes NSW 116252, 9.1915 (NSW); Desmond nr. Ravensthorpe, Maiden NSW 116253, 11.1909 (NSW); Esperance district, Rose, 11.1962 (PERTH); Fitzgerald R. Reserve, Royce 9192, 21.10.1970 (PERTH). Avon: Cowcowing, Koch 1235, 9.1904 (NSW). Irwin: Mullewa, Cleland, 26.8.1948 (AD 97234216); c. 4 miles [6 km] S. of Marchagee on Geraldton Hwy., Maslin 1414, 20.10.1970 (PERTH).

$S$. drummondii can become infected by the same type of nematode ("Cockle") as $S$. nitida (see note under the latter species). The following specimens are examples of this infection:

VictoriA: 15 miles [24 km] SSW, of Kerang, Beauglehole 40672, 1.11.1972 (NSW, IMI); Wyperfeld National Park, Beauglehole 28523, 19.9.1968 (NSW, IMI) p.p. 
Stipa echinata J. Vickery, S.W.L. Jacobs \& J. Everett, sp. nov.

S. stipoidem simulans, sed gluma inferiore longiore, lobis lemmatum brevioribus, callo longiore, et arista multo longiore, differt.

Holotype: South Australia: Hindmarsh I., E. of Goolwa, F.M. Hilton NSW 117382, 10.10.1945 (NSW).

Caespitose perennial c. 0.5 metres high with a basal tuft of leaves to half the height. Culms erect, terete, $1.5-2 \mathrm{~mm}$ wide near the base, not compressible, glabrous, smooth to strongly ribbed upwards; nodes $3-4$, \pm exserted, densely sericeous with white retrorse hairs $0.15-0.25 \mathrm{~mm}$ long, not swollen. Leaf sheaths tightly enveloping the culm, 3.5-7 mm wide, glabrous, sometimes minutely scaberulous between the ribs; basal sheath smooth to moderately ribbed, inner margin glabrous, outer margin ciliate with hairs $0.2-0.6 \mathrm{~mm}$ long, glabrous on the innovations; upper sheath strongly ribbed, inner margin glabrous, outer margin ciliate with hairs $0.3-1.3 \mathrm{~mm}$ long, minutely ciliate on the innovations. Ligule truncate to obtuse, membranous, $1.5-2.5 \mathrm{~mm}$ long, glabrous to ciliate with hairs $0.1-0.2 \mathrm{~mm}$ long; abaxial surface sericeous with hairs c. $0.1 \mathrm{~mm}$ long to glabrous; auricles, when present, thickened, c. $1 \mathrm{~mm}$ long, ciliate at the base with hairs to $1.2 \mathrm{~mm}$ long; auricular lobes glabrous, to $3.5 \mathrm{~mm}$ long. Leaf blade tightly rolled, $1-2 \mathrm{~mm}$ wide, to $15 \mathrm{~cm}$ long, pungent; abaxial surface smooth and glabrous; adaxial surface strongly ribbed, densely scaberulous with minute siliceous prickles, sometimes also with sparse villous hairs $0.2-0.5 \mathrm{~mm}$ long. Panicle 10-20 cm long, exserted, with distant fascicles of unequal, few-flowered, compound branches, \pm contracted, $1.5-3 \mathrm{~cm}$ wide (excluding awns); axis terete to slightly angled, glabrous to scabrous along the edges with hairs c. $0.1 \mathrm{~mm}$ long; branches $1.5-2.5 \mathrm{~cm}$ long, terete to slightly angled, scaberulous with hairs minute $-0.2 \mathrm{~mm}$ long; pedicels $2-10 \mathrm{~mm}$ long, slightly flattened to flattened, scaberulous with hairs minute- $0.1 \mathrm{~mm}$ long. Spikelets $21-23 \mathrm{~mm}$ long (excluding awn), gaping. Glumes unequal, acute-acuminate, straw-coloured, scaberulous to scabrous with hairs minute- $0.3 \mathrm{~mm}$ long or glabrous; lower glume $21-23 \mathrm{~mm}$ long, lower 50-65\% 3-nerved; upper glume $14-18 \mathrm{~mm}$ long, lower $40-60 \% 5$ (-7) -nerved, upper $60-40 \%$ (5-) 3-1-nerved. Floret cylindrical, without a neck, 8-10 mm long (including callus). Lemma surface smooth to slightly granular, densely sericeous with white hairs turning gold at maturity, $0.4-0.7 \mathrm{~mm}$ long; lobes $0.2-0.7 \mathrm{~mm}$ long, ciliate with hairs minute- $0.1 \mathrm{~mm}$ long; coma $0.6-1.2 \mathrm{~mm}$ long. Callus $2.6-3.2 \mathrm{~mm}$ long, weakly bent at the tip, densely sericeous with white hairs $0.1-1 \mathrm{~mm}$ long turning gold at maturity. Awn 9-11 cm long, with 3 weak bends, $0.3-0.5 \mathrm{~mm}$ wide near the base; column $3-3.5 \mathrm{~cm}$ long, $1-2 \mathrm{~cm}$ to the first bend, straw-coloured, densely pubescent with white hairs $0.2-0.8 \mathrm{~mm}$ long; bristle straw-coloured to brown, scabrous along the edges with hairs minute- $0.2 \mathrm{~mm}$ long. Palea \pm equal to the lemma, obtuse, smooth to slightly granular, sericeous along the centre back with hairs $0.2-0.8 \mathrm{~mm}$ long. Lodicules 2 (?3), abaxial, membranous, 1-1.5 mm long, oblong. Anthers 3.2-3.8 mm long, penicillate. Mature caryopsis not observed.

DisTRIBUtion: Coastal and near-coastal areas of South Australia.

Specimens Examined: South Australia: Eyre Peninsula: Reserve S. of Mt Verran, Cleland, 9.11.1960 (AD 968061288); Lincoln National Park, 34 $4^{\circ} 56^{\prime} \mathrm{S}, 135^{\circ} 55^{\prime} \mathrm{E}$, Heyligers $79005,6.11 .1979$ (CANB, AD). Murray: 2 miles [3 km] E. of Tintinara, Hilton, 11.10.1953 (ADW 44072). Yorke Peninsula: Point Davenport, nr. $35^{\circ} 12^{\prime} \mathrm{S}, 137^{\circ} 24^{\prime} \mathrm{E}$, Symon 11890, 4.11.1979, (NSW, dupl. of ADW); Pondalowie Bay, Blaylock 48, 10.10.1965 (AD). Southern Lofty: Hindmarsh I, E. of Goolwa, Hilton NSW $117382,10.10 .1945$ (NSW, dupl. of ADW).

Occurs mainly near the sea but follows the Murray River up at least a short distance. The tussocks are spiny-leaved (similar to $S$. stipoides) and give rise to 
the specific epithet. $S$. echinata differs from $S$. stipoides in having a longer lower glume, shorter lemma lobes, longer callus and much longer awns. S. echinata can be distinguished from $S$. flavescens by the spiny leaves, longer glumes and much longer awns. All three species are basically coastal.

Stipa elegantissima Labill., Nov. Holl. Pl. 1: 23, t. 29 (1804); Brown, Prodr.: 175 (1810); Hook. f., Fl. Tasman. 2: 111 (1858); Bentham, Fl. Austral. 7: 565 (1878); Hughes, Kew Bull. 1921: 11 (1921); Moore \& Betche, Handb. Fl. N.S.W.: 483 (1893); Ewart, Fl. Victoria: 179 (1931); Willis, Handb. Pl. Victoria 1: 181 (1962), edn 2, 1: 181 (1970); Black, Fl. S. Austral. 1: 65 (1922), edn 2: 86 (1943); Gardner, Fl. W. Austral. 1, Gram.: 172, pl. 50A (1952).

LECTOTYPE: There are two sheets at Florence (FI-W) annotated 'Nova Hollandia et Van Diemen'. One of these bears copious notes in Labillardière's handwriting and we here designate this specimen as Lectotype (isolectotypes G, B-W). S. elegantissima does not occur in Tasmania and it appears that Labillardière confused Western Australia and Tasmania on the labels as he has done elsewhere (see Willis, Muelleria 1: 136 (1967)). Bentham also points out that Labillardière's specimen from Captain Baudin in herb R. Brown is marked 'Nouv. Holl.', i.e. the more accurate locality information was probably added at a later date.

Caespitose perennial c. $0.5-1$ metre high, shortly rhizomatous, without a basal tuft of leaves. Culms decumbent, to 2 metres long, terete, $0.8-1.3 \mathrm{~mm}$ wide near the base, \pm compressible, smooth to slightly ribbed upwards, glabrous; nodes (3-) $6(-10)$, exserted, glabrous, $25-50 \%$ wider than the adjacent internodes. Leaf sheaths at first tightly enveloping the culm, later becoming slightly free, glabrous; lower sheath $2(-4) \mathrm{mm}$ wide, slightly ribbed; upper sheath (1.5-) 2-4 mm wide, slightly to moderately ribbed. Ligule obtuse, erose, membranous, 2-3 mm long, glabrous; auricles 2.3-3.6 mm long, not thickened, glabrous. Leaf blade tightly rolled, $1.5-2 \mathrm{~mm}$ wide, (3-) $5-7.5 \mathrm{~cm}$ long; abaxial surface very slightly ribbed, glabrous or scabrous; adaxial surface moderately ribbed, villous with hairs c. $1 \mathrm{~mm}$ long; margins glabrous or scabrous. Panicle $15-25 \mathrm{~cm}$ long, exserted, pyramidal, with whorls of long, few-flowered, compound branches, spreading widely, $8-15 \mathrm{~cm}$ wide when expanded (excluding awns), disarticulating at maturity; axis terete (to slightly angular), plumose with hairs $1.5-2.5 \mathrm{~mm}$ long (to glabrous); branches (2.5-) 4.5-5.5 (-8) cm long, terete, plumose with hairs $1.5-3 \mathrm{~mm}$ long; pedicels $2-3 \mathrm{~cm}$ long, terete, plumose with hairs $(1.5-) 2 \mathrm{~mm}$ long. Spikelets (7-) 8-10 (-12) mm long (excluding awn), gaping at maturity. Glumes subequal (to unequal), rounded on the back, acute, purple with a strawcoloured tip, pilose on the nerves with hairs $0.25-1 \mathrm{~mm}$ long, scabrous between the nerves, margins glabrous; lower glume (7-) 8-10 (-12) $\mathrm{mm}$ long, lower $50-60(-66) \%$ 3-nerved; upper glume 7-9 (-11) mm long, lower 60-70\% 3nerved. Floret narrowly cylindrical tapering to the apex, 4.5-6.5 (-10) mm long (including callus). Lemma black at maturity, the surface tuberculate, mainly glabrous but with hairs $0.5-0.7 \mathrm{~mm}$ long along the lower half of the lemma margins; lobes minute- $0.8 \mathrm{~mm}$ long; coma absent. Callus $0.5-0.8 \mathrm{~mm}$ long, almost straight, sericeous with white hairs $0.5-1.0(-1.2) \mathrm{mm}$ long. Awn $2-5 \mathrm{~cm}$ long, $0.1-0.2 \mathrm{~mm}$ wide near the base, strongly once bent, often with another weak bend; column 8-15 (-20) mm long, straw-coloured, scabrous with hairs (0.1-) $0.2 \mathrm{~mm}$ long; bristle darker than the column, scabrous with hairs $0.05 \mathrm{~mm}$ long. Palea c. $50 \%$ the length of the lemma, acute, surface granular, glabrous. Lodicules 2, abaxial, $0.5-0.7 \mathrm{~mm}$ long, oblong. Anthers $1.5-3 \mathrm{~mm}$ long, penicillate. Caryopsis $4-5 \mathrm{~mm}$ long; embryo $20 \%$ the length; hilum $60-80 \%$ the length. 
Distribution: Southern Western Slopes and Plains of New South Wales, extending into Victoria, across the mallee regions of South Australia and the southern regions of Western Australia.

Selected Specimens: New South WALES: Central Western Slopes: Muswellbrook, Blakely NSW 115786, 10.1911 (NSW); Peak Hill, Boorman NSW 115796, 11.1905 (NSW); Cunninyeuk, Henderson NSW 115948, 9.1946 (NSW); 'Lake Cowral' Station, Marsden, Wilson NSW 115789, 12.1917 (NSW); Wyalong, Boorman NSW 121577, 11.1917 (NSW, CANB, BRI); Alleena via Barmedman, Winter NSW 115798, 6.1931 (NSW); Ashbridge via Matong, Cahill NSW. 115790, 11.1907 (NSW). South Western Slopes: Coolamon, Bridle NSW I15785, 5.1940 (NSW); Milbrulong, Dwyer NSW 115791, 11.1926 (NSW). North Western Plains: Nyngan, Blakely NSW 115792, 10.1912 (NSW). South Western Plains: Tullamore district, Fishpool, no collector NSW 115781, 11.1966 (NSW); W, of Weethalle, Gauba CBG 008951, 15.12.1950 (CBG); 10 miles [16. km] N. of Oxley on Booligal road, De Nardi 1002, 10.1972 (NSW); near Griffith, J.C.N. NSW 72702, 11.1964 (NSW); W. of Griffith on Rankin Springs road, Cunningham NSW 115780, 10.1971 (NSW); 'Zara' via Hay, Officer NSW 115797, 11.1903 (NSW); 40 miles [64 km] N. of Balranald, Alchin NSW 120329, 7.1970 (NSW); 7.9 miles [12.8 km] W. of Balranald, De Nardi 1017, 10.1972 (NSW); Narrandera, Warby, 1895 (MEL); 30 miles [61 km] W. of Moulamein, Moore 15.10.1971 (CANB); Hillston to Rankin Springs road, Constable NSW 4595, 10.1947 (NSW); Wanganella, Mulham NSW 97805, 8.1967 (NSW); Tulla, Barham district, Henderson NSW 115787, 1945 (NSW). North Far Western Plains: Barrier Range, Woolls NSW 115782, s.d. (NSW); 'Mundi Mundi' Station near Broken Hill, Constable NSW 4681, 11.1947 (NSW). South Far Western Plains: Junction of the Murray \& Darling Rivers, Wentworth, Holding, 1890 (MEL).

ViCTORIA: Region A: $30 \mathrm{~km}$ SSW. of Mildura, $9 \mathrm{~km} \mathrm{~S}$. of Benetock, along Meridian road, Crisp 3287, 9.10.1977 (CBG); Hattah Lakes National Park, Anderson, 9.12.1965 (MEL). Region C: Jeparit, no collector, 14.10.1912 (MEL); 3 miles [5 km] NW. of Kanwa, Melville et al. 886, 15.9.1952 (NSW); Shire of Dimboola, Reader, 23.10.1893 (MEL); Mt Arapiles, Corrick 1358, 24.11.1968 (NSW). Region G: Kulwin, Baker, 20.10.1926 (BRI); Swan Hill district, French, 10.1888 (MEL). Region H: mallee scrub, Borung, Reader, 8.1911 (MEL). Region J: Stawell, Holt, s.d. (MEL). Region M: Nathalia, Black, 11.11.1932 (CANB 9757); Bendigo, Whipstick, Hart, 11.1947 (MEL). Region N: Daylesford, Wallace, 1878 (MEL); nr. Bacchus Marsh, Tovey \& French, 3.11.1910 (MEL, PERTH). Region P: Mornington Peninsula, Frankston, Willis NSW 116706, 8.1.1969 (NSW, MEL). Region S: Woods Point, no collector, 25.10.1931 (ADW).

SOUTH AUSTRALIA: Nullarbor: Barton (c. $345 \mathrm{~km} \mathrm{E}$. of the Western Australian border, on the railway), Ising $386 \&$ 1336, 20.9.1920 (AD); 4 miles [6 km] inland from cliff tops, Koonalda, Symon 4597, 17.2.1967 (ADW). Flinders Ranges: Blinman Cemetery, Frances, 10.1971 (AD); Oraparinna National Park, Symon 7573, 16.9.1971 (ADW); between Wilson \& Warren, Crocker, 2.10.1944 (CANB 11595); between Wilson \& Gordon, Willochra Plain, Burbidge, 1.9.1946 (CANB 12811); Pichi Richi Pass, Lothian 3057, 7.11.1964 (AD); Mt Remarkable, Melrose, Eardley, 2.9.1946 (ADW 19772). Eastern: N. of Curnamona, Symon 8033, 18.9.1972 (ADW); Koonamore, Crisp 635, 22.10.1973 (CBG); Mutooroo, Morris, 12.8.1921 (ADW 15069). Eyre Peninsula: Coorabie, Cleland, 18.10.1953 (AD); 12 miles [19 km] N. of Koonibba siding, Symon, 30.9.1959 (ADW 21350); Yudnappina, Douglas, 9.1939 (ADW 18280, 22952); Gawler Ranges, $10 \mathrm{~km} \mathrm{~N}$. of Yardea, Symon 8155, 8.10.1972 (ADW); Whyalla Knob, Cleland, 1.9 .1944 (AD); c. 4 miles [6 km] S. of Mambray Creek, Copley 1586, 10.10.1967 (AD); Hambidge National Park (c. $140 \mathrm{~km} \mathrm{~N}$. of Port Lincoln), Kraehenbuehl 2071, 9.10.1966 (AD); c. 11 miles [18 km] SSW. of Port Broughton, Morris, 28.8.1946 (MEL); 57 miles [91 km] from Port Lincoln towards Cowell, Wrigley CBG 037424, 21.11.1968 (CBG); 3 miles [5km] N. of Cowell, Tindale 454, 12.11.1970 (CANB, BRI). Northern Lofty: Bundaleer, Monarto South, Symon 3139, 20.11.1964 (ADW); Hincks National Park, Symon 6515, 13.10.1968 (ADW); Barunga Gap Cemetery, Copley 1502, 4.10.1967 (AD); Northern Tothill Range, Niblet Gap, Kraehenbuehl 2172, 29.10.1967 (AD); South Hummocks Range, Blaylock 723, 1.10.1967 (AD); Saddleworth, Symon, 27.10.1960 (ADW 22951); Freeling, Kraehenbuehl 1487, 18.11.1965 (AD). Murray: 'Baldina' Station, Jackson 379, 9.10.1961 (BRI); 3 miles [5 km] W. of Bower, Boehm 410, 16.10.1963 (AD); Overland Corner, Symon 3882, 12.10.1965 (ADW); between Kingston \& Waikerie, Whibley 2651, 28.9.1968 (AD); N. of Owen, Hilton, 11.9.1951 (ADW 43863); Loveday, Gauba CBG 003982, 12.8.1944 (CBG); Old Coach Road Block 73, County Hamely, Symon 3803, 11.10.1965 (ADW); 1 mile [1.6 km] E. of Truro, Kraehenbuehl 690, 22.9.1962 (BRI); Barossa Valley, Wells, 31.7.1952 (ADW 8004); Mannum, Blake 16841, 24.8.1946 (BRI). Yorke Peninsula: near Port Germein, Phillips CBG 054565, 14.9.1973 (CBG); Mona Railway Yard, Copley 873, 8.11.1966 (AD); 4 miles [6 km] from Moonta towards Maitland, Phillips CBG 042829, 2.10.1965 (CBG); Hardwicke Bay, Smith 756, 25.10 .1967 (AD); Greenly Island, North Island, c, $100 \mathrm{~km}$ W. of Port Lincoln, Adelaide Bushwalkers, 4-17.12.1947 (AD); Innes National Park, Symon 9545, 6.10.1974 (ADW, NSW). Southern Lofty: Roseworthy Agricultural College, Hilton, 23.10.1939 (ADW 28137); 1 mile [1.5 km] W. of Willaston, Belcher, 31.10.1967 (MEL); 2.5 miles [4 km] 
WNW. of Gawler, Smith 958, 23.10.1967 (AD); Highbury, Smith 1565, 28.11.1968 (AD); E. side of the Port River between Granger \& Royal Park, Smith 914, 21.10.1967 (AD); Tea Tree Gully, Dillon Road, Spooner 325, 12.10.1968 (AD); Christies Beach, Perry, 9.1944 (CANB 18356); c. 1 km NE. of Finniss, Whibley 3683, 26.10.1971 (AD); near Milang, c. $65 \mathrm{~km} \mathrm{SSE}$. of Adelaide, nr. Lake Alexandrina, Whibley 870, 8.10.1962 (AD). Kangaroo Island: Kingscote, Jackson 219, 16.9.1920 (AD).

Western Australia: Carnegie: Barwidgee road, 11.5 miles [18 km] S. of Yelma turn off, Speck 1347, 7.9.1958 (CANB, PERTH). Ashburton: Upper Murchison River, Tyson 90, 1892 (MEL). Austin: 103 miles [165 km] SSE. of Carnarvon, Beauglehole 11789, 21.8.1965 (CANB, PERTH); Mt Narryer, Murchison River, Tyson 33, 1898 (PERTH); 65 km NE. of Laverton, Beauglehole 59899 \& Errey, 16.9.1978 (PERTH, NSW). Coolgardie: Lake Moore, Gardner, 10.1939 (PERTH); Camp 61, c. $160 \mathrm{~km}$ ESE. of Kalgoorlie, Elder Expedition, Helms, 25.9.1891 (AD); NE. of Kalgoorlie, Gauba CBG 003955, 10.10.1955 (PERTH); c. 4 miles [6 km] from Kalgoorlie towards Coolgardie, Phillips CBG 025825, 15.9.1962 (CBG, AD); 8 miles [15 km] SE. of Boulder, SE. of Kalgoorlie, Beauglehole 13266, 20.9.1965 (PERTH); Kurrawang, Kessel, 9.1921 (PERTH); $48 \mathrm{~km}$ W. of Coonana near Cardonia Rocks, Chinnock 1141,18.9.1973 (AD); c. $20 \mathrm{~km} \mathrm{E.} \mathrm{of} \mathrm{Southern} \mathrm{Cross,}$ Kuchel 2121, 23.9.1964 (AD); Pioneer Rock, N, of Lake Cowan, Burbidge 2672, 19.9.1947 (CANB); Fraser Range, Aplin 1771, 6.9.1962 (PERTH); 4 miles [6 km] N. of Norseman on Coolgardie road, Beauglehole 13329, 21.9.1965 (CANB, PERTH); Norseman, Galbraith, 18.10.1964 (MEL); 2 miles [3 km] S. of Lake Kirk, Burbidge 2685, 20.9.1947 (CANB); Lake Hope, Beard 3796, 23.10.1964 (PERTH); Dundas Rocks, 10 miles [16 km] S. of Norseman, Beauglehole 13200, 18.9.1965 (CANB, PERTH). Roe: 5 km NW. of Ongerup, Newbey 4590, 16.11.1974 (PERTH). Avon: 6 miles [8 km] E. of Ballidu, Royce 2167, 13.9.1947 (PERTH); Cowcowing, Koch 1133a, 8.1904 (PERTH); Yelbine [Yelben], Carne, 11.1925 (PERTH); Merredin, Carne, 10.1923 (PERTH); Muntadgin, Bailey 177, 9.1945 (PERTH); Wagin, Gardner 485, 25.10.1920 (PERTH). Irwin: Dirk Hartog Island, George, 9.1972 (PERTH); between Denham \& Monkey Mia, Beard 6770, 9.10.1973 (NSW, PERTH); 1 mile [1.6 km] S. of Wannoo, Phillips CBG 035348, 16.9.1968 (MEL); Champion Bay, Guerin, 1871 (MEL); c. $70 \mathrm{~km} \mathrm{NE.} \mathrm{of} \mathrm{Geraldton,} \mathrm{Muir} \mathrm{82(FF),} \mathrm{12-16.10.1976} \mathrm{(PERTH);} 7$ miles [11 km] N. of Geraldton, Burbidge 2048, 2.9.1947 (CANB); Geraldton, Carriage \& Ollerenshaw CBG 062572, 5.10.1975 (CBG, PERTH); between Geraldton \& Northampton, Blake 18083, 2.9.1947 (PERTH, BRI); West Wallabi Island, Abrolhos Islands, Storr, 9.1959 (PERTH); East Wallabi Island, Abrolhos Islands, Gilham, 7.9.1959 (PERTH); 'Karara' Station, Beard 7193, 28.10.1974 (PERTH); Yandanooka, Morrison, 16.9.1904 (PERTH, BRI). Darling: Goomalling, Pullen 9618, 25.11.1974 (CANB, NSW); Woorooloo-Bailup road, S. of Toodyay road, Burbidge 7992, 4.1 .1972 (CANB); Wooroloo, Koch, 11.1907 (MEL); Darlington, Helms, 9.1898 (PERTH); Cottlesloe, Andrews, 9.1903 (PERTH); Upper Swan River, Sewel, 1855 (MEL); Blackwood River, Hester, 1876 (MEL). Eyre: Pallarup Rocks, SE. of Lake King, George 1547, 13.10.1960 (PERTH); Oldfield River crossing on Ravensthorpe-Esperance road, Jackson 1409, 13.10.1968 (PERTH); nr. Culham Inlet, George 605, 31.1.1960 (PERTH).

Palatable to stock and now found growing chiefly in situations sheltered from grazing, e.g. under and through the branches of shrubs or fallen timber; it was probably at one time much more abundant.

Stipa eremophila Reader, Victorian Naturalist 17: 154 (1901); Black, Fl. S. Austral. 1: 65 (1922), edn 2: 90, fig. 110 (1943); Gardner, Fl, W. Austral. 1, Gram.: 180 (1952); Willis, Handb. Pl. Victoria 1: 186 (1962), edn 2, 1: 186 (1970).

\section{Holotype: Victoria: Sandy Desert, Lowan, 1898, F.M. Reader (MEL 59873!).}

SYNONYMS: Stipa pubescens var. auricoma Reader, Victorian Naturalist 17: 156 (1901). HolOTYPE: VictoRIA: November, 1897, Desert, Lowan; F.M. Reader (not seen). We have seen a specimen in the Melbourne Herbarium (MEL 60695) labelled by Reader 'Stipa aristiglumis F.v.M. var. auricoma, Little Desert, Lowan, 16.10.1898. Coll. F.M. Reader' which, in the absence of the Holotype, we are accepting as the basis for our concept of this variety. This specimen is $S$. eremophila with immature spikelets in which the hairs of the lemma have not yet attained the yellowish to reddish brown colour described by Reader for his variety and characteristic of more mature spikelets of $S$. eremophila.

S. fusca C.E. Hubbard, Kew Bull. 1925: 432 (1925). Holotype: South Australia: Eyre Peninsula, Iron Knob, Cleland 3, 22.8.1921 (K!; isotypes AD 9723153 and NSW 9317). Populations 
of $S$. eremophila show considerable variation in length of both callus and body of the lemma. $S$. fusca was described from specimens at the extreme of the range in elongation of the callus combined with brevity of the body of the lemma. This combination of characters results in a somewhat distinctive appearance compared with the average proportions of the callus and body of the lemma in $S$. eremophila. However, so many intermediate gradations may be found that we are convinced that this form is unworthy of recognition.

S. variegata Summerhayes \& Hubbard, Kew Bull. 1927: 363 (1927); Black. Trans. \& Proc. Roy. Soc. South Australia 63: 241 (1939). HolotypE: SOUTH AuSTRALIA: Sandergrove near Lake Alexandrina, 21.10.1926 (K; isotype AD 96323303; CANB photo 237008). In the Type the hairs on the lemmas are white, not fulvous, although a slight yellowing can be detected in a lemma of the duplicate; we regard this difference in colour, together with the slenderness of the lemma, to be due to the immaturity of the specimen. This specimen can be matched with immature material of $S$. eremophila. We have been unable to recognise any populations that could justify recognition of $S$. variegata as distinct from $S$. eremophila.

S. dura J. Black, Trans. \& Proc. Roy. Soc. S. Austral. 65: 333 (1941); Fl. S. Australia edn 2, 1: 86-87 (1943), in part. HolotyPE: SouTH Australia: Nullarbor Station (near Fowlers Bay), Black, 1911 (AD 97424089). The Holotype is very imperfect, but we have no doubt that the spikelets agree with $S$. eremophila. Mounted on the same sheet is a specimen from Cape Thevenard (cited by Black, F1. South Australia) that, although also rather imperfect, appears to be $S$. flavescens Labill.

Caespitose perennial to c. 0.9 metres high, with a basal tuft of leaves at least half the total height. Culms erect or geniculate, $1-1.5 \mathrm{~mm}$ wide near the base, terete, slightly compressible, scarcely ribbed, glabrous and smooth to minutely scaberulous or puberulous; nodes $2-3$, appressed-pubescent to almost glabrous, exserted, to $60 \%$ wider than adjacent internodes. Leaf sheaths tight around the culms, c. $4 \mathrm{~mm}$ wide (the uppermost inflated and to $8 \mathrm{~mm}$ wide), finely pubescent or hirsute or glabrous, especially upwards; inner margin glabrous; outer margin ciliate, more so just below the orifice. Ligule coriaceous, 0.5-1.5 mm long, truncate (although often torn), densely ciliate; abaxial surface glabrous to pubescent; auricles densely to sparsely ciliate with straight or crinkly hairs or glabrous. Leaf blades mostly rolled, $1.5-4 \mathrm{~mm}$ wide, to $30 \mathrm{~cm}$ long, abaxial surface scarcely ribbed, glabrous to hirsute; adaxial suface ribbed, scaberulous, densely pubescent or hirsute to almost glabrous; margins scabrous or similar to adjacent surface. Panicle spreading at maturity, $15-30 \mathrm{~cm}$ long, 2-7 cm wide (excluding awns), exserted; axis terete, glabrous to sparsely pubescent; branches 10-60 mm long, angular, scaberulous to scabrouspubescent; pedicels $2-15 \mathrm{~mm}$ long, flattened, scaberulous to scabrous-pubescent. Spikelets $15-25 \mathrm{~mm}$ long (excluding awn), slightly gaping. Glumes unequal, at least the lower usually broad and inflated, rarely narrow, glabrous or scaberulous on the nerves; lower $15-25 \mathrm{~mm}$ long, long-acuminate, the lower $50-75 \% 3$-nerved, pale or usually with a crescentic purple patch in the middle third; upper $10-18 \mathrm{~mm}$ long, acuminate, the lower $30-50 \%$ 5-nerved, 50-75\% 3nerved, pale or purple at the base. Floret turbinate to cylindrical, usually with a neck, 6-9.5 mm long (including callus). Lemma deep brown at maturity, the surface smooth, sericeous with dense fulvous hairs, but the upper $0.5-1.5 \mathrm{~mm}$ scabrous with much shorter but otherwise similar hairs; lobes 2 , obtuse to broadly acute, $0.2-0.4(-0.75) \mathrm{mm}$ long (rarely to $1.5 \mathrm{~mm}$ long, and then acute); coma of sparse stiff hairs $0.4-0.7 \mathrm{~mm}$ long. Callus $2-4 \mathrm{~mm}$ long, straight or slightly curved when short, sericeous with dark fulvous hairs. Awn sturdy, $0.25-0.4 \mathrm{~mm}$ wide near the base, $5-9(-11) \mathrm{cm}$ long, twice bent; column pale, $15-38 \mathrm{~mm}$ long, $7-16 \mathrm{~mm}$ to the first bend, pubescent with hairs $0.2-0.4$ $(-0.5) \mathrm{mm}$ long to almost glabrous with few hairs to $0.1 \mathrm{~mm}$ long; bristle pale or purple-tinged, scaberulous or pubescent with hairs to $0.25(-0.5) \mathrm{mm}$ long. Palea acute, from slightly shorter to slightly longer than the lemma, ciliate at the tip, granular, densely sericeous between the nerves, the margins membranous and 
glabrous. Lodicules 3 , membranous; 2 abaxial $1-1.5 \mathrm{~mm}$ long, obtuse to spathulate; paleal $0.5-1.5 \mathrm{~mm}$ long, obtuse to acute. Anthers $2.5-4 \mathrm{~mm}$ long, penicillate. Caryopsis 3.5-4.5 mm long; embryo $30 \%$ the length; hilum $80 \%$ the length.

DisTRIBUTION: Southern Slopes and Plains of New South Wales, north-western regions of Victoria, across the southern half of South Australia and the Nullarbor Plain into the south of Western Australia. Mainly in woodlands or mallee but not uncommon on the limestone areas of the Nullarbor Plain.

Selected Specimens: New South Wales: South Western Slopes: Urana, W. of Wagga Wagga, Libke, 26.9.1968 (CANB). South Western Plains: Griffith, Jacobs 4159 \& Everett, 24.9.1981 (NSW); Kyalite, Everett 60 \& Jacobs, 22.11.1980 (NSW); Cunninyeuk near Wakool between Moulamein \& Swan Hill, Henderson 177, 8.10.1946 (MEL; NSW); N. of Stony Crossing, Everett 88 \& Jacobs, 23.11.1980 (NSW); 3 miles [5 km] W. of Stony Crossing, Henderson 43I, 9.10 .1947 (NSW); Trida district, Stannard NSW 116344, 8.10.1956 (NSW); W. of Tueloga Siding, Henderson 430, 14.10.1947 (NSW); Meran Creek, between Swan Hill \& Moulamein, Henderson 435, 5.12.1947 (NSW); E. end of Pt Poon Boon, SE. of Stony Crossing, Henderson 427, 23.9.1947 (NSW); NE. of Lake Tooim, Henderson 432, 5.11.1947 (NSW). North Far Western Plains: 11 miles [18 km] S. of Broken Hill, Jacobs 176, 11.11.1971 (NSW); Broken Hill, Morris NSW 9325, 11.1920 (NSW, K). South Far Western Plains: 135 miles [216 km] S. of Broken Hill, Richley 1464, 2.9.1974 (NSW); near Thackaringa, Morris 13925, 6.11.1920 (ADW); 13 miles [21 km] E. of Darnick, De Nardi 1095, 22.10.1972 (NSW); $39 \mathrm{~km}$ from Wentworth, 'Nulla Nulla' road, Everett 117 \& Jacobs, 25.11.1980 (NSW); $6 \mathrm{~km}$ NE. of Euston, Balranald road, Everett 105 \& Jacobs, 24.11.1980 (NSW); ridge above Lake Benemee, near Euston, Henderson 423, 5.10.1947 (NSW).

VICtORIA: Region A: Sunny Cliffs, S. of Mildura, Beauglehole 16033, 20.9.1966 (NSW). Region B: Bronzewing Wildlife Reserve, 15 km SSE. of Ouyen, Beauglehole 56965, 25.10.1977 (MEL); Beulah, Connor, 10.1963 (MEL). Region C: Broughton, no collector (MEL); $18 \mathrm{~km}$ SW. of Warracknabeal, Dimboola road, Everett 172 \& Jacobs, 29.11.1980 (NSW); Kaniva, Watts NSW 9327, 10.1917 (NSW). Region F: 14 km SSE. of Robinvale, Beauglehole 56070, 3.5.1977 (MEL). Region G: 5 km SW. of Chinkapook, c. $18 \mathrm{~km} \mathrm{~S}$. of Manangatang, Beauglehole 55493, 17.4.1977 (MEL); $17 \mathrm{~km} \mathrm{SSW.} \mathrm{of}$ Swan Hill, Beauglehole 56001 and Macfarlane, 1.5.1977 (MEL). Region H: Borung, Reader, 28.10.1904 (MEL, AD).

SOUTH AUSTRALIA: Nullarbor: N. of Cook, Hilton, 22.8.1955 (ADW); vicinity of Koonalda Cave, Symon 4490, 16.2.1967 (ADW); 'Nullarbor' Station, Black NSW 9321, 6.1911 (NSW); W. of Wigunda, Phillips CBG 016293, 7.9.1962 (CBG), Gairdner-Torrens Basin: $5 \mathrm{~km}$ N. of 'Bon Bon', Donner 1707, 8.9.1966 (AD). Flinders Ranges: 10 miles [16 km] N. of Hawker, Hilton, 2.10.1954 (ADW); Waterfall Creek near Baroota, Kraehenbuehl 194, 18.9.1960 (AD); Waukaringa, between Yunta \& 'Koonamore', Symon, 19.12.1954 (AD); Craddock, on Wilson road, Hilton NSW 116343 , 1.10.1954 (NSW, ADW); Orroroo, Black, 6.10.1910 (AD). Eastern: Mt Victor, Lay \& Crisp 439, 4.9.1971 (AD, CBG); 'Koonamore', Everelt 162 \& Jacobs, 28.11.1980 (NSW); Yunta, Black, s.n., s.d. (MEL). Eyre Peninsula: $65 \mathrm{~km}$ from Ceduna along Eyre Highway towards Poochera, Crisp 5762, Taylor \& Jackson, 12.9.1979 (CBG); E. slope of Iron Knob, 50 miles [80 km] NW. of Whyalla, Hilton, 14.9.1951 (ADW); Kimba, Cleland, 8.10.1932 (ADW); Gawler Ranges, S. of Scrubby Peak, $24 \mathrm{~km} \mathrm{~N}$. of Minnipa, Wilson 527, 16.10.1958 (AD, K); c. 11 miles [18 km] SSW. of Port Broughton, Blake 16847, 28.8.1946 (BRI); c. $35 \mathrm{~km}$ W. of Colona, Cleland, 9.11.1955 (AD), Northern Lofty: halfway between Wintinerta and Bute - Kadina bitumen, Copley-658, 24.9.1966 (AD); 1 mile [1.6 km] W. of Balaklava, Clarke, 13.10 .1936 (ADW); Mallala, Harris 31, 1.10.1959 (AD); S. of Freeling, Kraehenbuehl 1783, 6.11.1966 (AD). Murray: 8 miles [13 km] from Morgan towards Burra, Phillips CBC 018940, 2.9.1962 (CBG); Hundred of Bower, Ioannov 52, 5.4.1968 (AD); E. of Sutherlands township, Bohem 314, 9.1958 (AD); road to Walkers Flat, Cleland, 8.10 .1966 (AD); Murray Bridge, Cleland, 7.3.1941 (AD). Yorke Peninsula: Mission Station, Pt. Victoria, Beck, 2.1942 (ADW); 26 miles [42 km] from Yorketown towards Foul Bay, Phillips $C B G$ 026876, 19.10.1966 (CBG). Southern Lofty: 1 mile [1.6 km] past Kangaroo Flat on Mallala road, Harris 45, 11.1959 (AD); Marino, Cleland, 8.10.1932 (AD); Hallet Cove, Cleland NSW 116969, 28.10.1932 (AD, NSW); Balaklava, 42 miles [67 km] NNW. of Gawler, Hilton NSW 116342, 1.10.1944 (NSW, ADW); Echunga, Parsons 163, 27.10.1961 (AD). South-eastern: 1 km from Keith on Adelaide road, Specht, 9.1949 (AD); Millicent, Cleland, 14.10.1949 (AD).

WeStERn Australia: Eucla: 3 miles [5 km] S. of Reid, Aplin, 1.9.1962 (PERTH); 1 mile [1.6 km] W. of Forrest, Calaby, 24.10.1947 (CANB, BRI); Loongana, Mitchell 69, 11.9.1974 (PERTH); 50 miles [80 km] NNE. of Rawlinna, Brooker 171, 5.9.1974 (CANB); $26 \mathrm{~km} \mathrm{E.} \mathrm{of} \mathrm{Rawlinna,} \mathrm{Goodall}$ 
2698, 18.8.1966 (PERTH); Rawlinna, Wilson 5799, 15.5.1967 (PERTH); 50 km S. of Rawlinna on road to Cocklebiddy, George 11886, 13.7 .1974 (PERTH); 12 miles [19 km] from Madura towards Cocklebiddy, Eyre Highway, Phillips CBG 039214, 1.9.1968 (CBG, BRI); 46 km WSW. of Madura, Beauglehole 49403, 30.8.1974 (CANB). Coolgardie: $5 \mathrm{~km} \mathrm{W.} \mathrm{of} \mathrm{Coolgardie,} \mathrm{Hacker} \mathrm{3,} \mathrm{11.3.1971}$ (PERTH); $30 \mathrm{~km}$ E. of Kitchener on Trans-Australian Railway, Wilson 7644, 2.9.1968 (PERTH); $147 \mathrm{~km} \mathrm{E}$. of Zanthus, Goodall 2723, 24.9.1966 (PERTH); Cunderlee Mission, N. of Zanthus, George 5893, 22.9.1963 (PERTH); Fraser Range, Helms NSW 9320, 30.10.1891 (NSW); 14 miles [22 km] N. of Norseman on Coolgardie road, Beauglehole 1335, 21.9.1965 (NSW); c. $160 \mathrm{~km} \mathrm{E.} \mathrm{of}$ Balladonia, Jackson 1470, 24.10.1968 (PERTH). Darling: $5 \mathrm{~km} \mathrm{NW.} \mathrm{of} \mathrm{Wongan} \mathrm{Hills} \mathrm{town,} \mathrm{Crisp}$ 6323, Taylor \& Jackson, 2.10.1979 (CBG).

$S$. eremophila has a greater range of variation than most of the other Australian species of Stipa. Several of the recently described species are related to $S$. eremophila; each of these forms uniform populations differing in one or more characters from true $S$. eremophila. It is not uncommon to find individual specimens of $S$. eremophila with characters different from those accepted here as being characteristic of the species. Where the variants occur in populations dominated by what we regard as true $S$. eremophila these variants are not being recognized as taxonomically distinct. The anomolous characters seem to be relatively uncommon and not correlated with either other characters or variations in habitat. Common variations include long lemma lobes, hairy bristles (approaching $S$. plumigera), hairy orifices and almost glabrous lemmas. Examples are cited here of specimens with (i) long lemma lobes and (ii) hairy bristles (see $S$. lanata for a discussion of the latter two variations):

(i) New South Wales: South Western Plains: 3 miles [5 km] W. of Stony Crossing, Henderson 431, 9.10.1947 (NSW); SE. of Stony Crossing, Henderson 427, 23.9.1947 (NSW); W. of Tueloga [as Tucloga] Siding, Henderson 428, 29.9.1947 (NSW). South Australia: Murray: Oakbank Station, Cleland, 21.9.1968 (AD 97308293).

(ii) Victoria: Region A: Mildura, Sonenberg 1937, 4.11.1935 (K). South AuStralia: Nullarbor: Between Eucla \& Fowlers Bay, Richards (MEL 60925). WESTERN AUSTRALIA: Eucla: 3 km N. of Eucla, Whibley 632, 14.9.1960 (AD); c. $70 \mathrm{~km}$ W. of Madura, Kuchel 1570, 9.9.1964 (AD).

Stipa exilis J. Vickery, Telopea 2(1): 13 (1980).

Holotype: South Australia: Northern Yorke Peninsula, section 155, Hundred of Willunga (about $140 \mathrm{~km}$ NNW. of Adelaide), B. Copley 799, 21.10.1966 (AD 9670326).

Densely caespitose perennial to 0.6 metres high with mostly intravaginal basal leaves to about half the height. Culms usually geniculate or erect, to $1 \mathrm{~mm}$ wide near the base, terete, compressible, ribbed, puberulous or scaberulous just below the nodes otherwise glabrous or puberulous; nodes 2, finely pubescent, usually exserted, up to $50 \%$ broader than adjacent internodes. Leaf sheaths tightly enclosing the culm although basal sheaths loose, c. $5 \mathrm{~mm}$ wide, ribbed, scaberulous and pubescent and/or hirsute; inner margin \pm glabrous; outer margin short- or long-ciliate or glabrous. Ligule firmly membranous, obtuse, $0.5-2.5 \mathrm{~mm}$ long, often continuous with the sheath margin; margin glabrous or ciliate; abaxial surface puberulous; auricle with a dense to sparse tuft of long, straight or woolly hairs. Leaf blades loosely convolute, flexuose, less than $0.5 \mathrm{~mm}$ in diameter, to $25 \mathrm{~cm}$ long; abaxial surface slightly ribbed, scaberulous and pubescent and/or hirsute; adaxial surface strongly ribbed, pubescent; margins scabrous with short hooks. Panicle loosely contracted or narrowly spreading, moderately sparse, to $20 \mathrm{~cm}$ long, to $3 \mathrm{~cm}$ wide (excluding awns), exserted at length, with fascicles of unequal, few-flowered branches; axis terete or slightly angular, scaberulous; branches to $7 \mathrm{~cm}$ long, slightly angular, scaberulous. Pedicels to $10 \mathrm{~mm}$ long, slightly angular, scaberulous. Spikelets 
8-10 mm long (excluding awn), gaping narrowly. Glumes unequal, firm and green at the base, purple-tinged to hyaline at the tip, scaberulous on the nerves or scaberulous overall; lower glume 8-10 (-12) mm long, acuminate, the lower $50-60 \% 3$-nerved; upper glume $7-8 \mathrm{~mm}$ long, acute or obscurely dentate, the lower $50-70 \%$ 5-nerved, the next $10 \%$ 3-nerved. Floret linear-cylindrical to fusiform, 4.5-5.5 mm long (including callus). Lemma black at maturity, the main nerve paler, very finely granular to coarsely granular at the apex, with sparse erect and spreading hairs, white to bright gold at maturity; coma obscure, $0.6-0.8 \mathrm{~mm}$ long; lobes 2 , to $0.25 \mathrm{~mm}$ long. Callus $1-1.5 \mathrm{~mm}$ long, sturdy, straight, with hairs similar to those of the lemma. Awn 35-55(-60) mm long, $0.2 \mathrm{~mm}$ wide near the base, gently twice bent; column $15-21 \mathrm{~mm}$ long, 9-15 mm to the first bend, scaberulous with hairs to $0.2 \mathrm{~mm}$ long; bristle scaberulous. Palea broad-acute to obtuse, to $0.5 \mathrm{~mm}$ shorter than the lemma, coriaceous, smooth, sericeous down the centre, hyaline and glabrous on the margins, the tip ciliate. Lodicules 3, membranous; 2 abaxial c. $1 \mathrm{~mm}$ long, cuneate; paleal less than $0.5 \mathrm{~mm}$ long, triangular-acute. Anthers 1-2 mm long, penicillate. Caryopsis 3-3.5 mm long; embryo $25 \%$ the length; hilum $70-90 \%$ the length.

Distribution: Heath and scrub on sandy soil in southern South Australia, barely extending into Victoria and Western Australia (although not on the Nullarbor Plain).

Selected Specimens: Victoria: Region D: 10 miles [16 km] SW. of Dergholm, Beauglehole 38083, 18.12.1971 (NSW).

South Australia: Eyre Peninsula: 15 miles [24 km] from Poochera towards Minnipa, Eyre Highway, Canning 2277, 30.8.1968 (CBG, NSW); Hambridge National Park, Kraehenbuehl 2070, 8.10.1966 (AD); between Prominent Hill \& S. edge of Hambridge Reserve, Symon 4118, 8.10.1966 (ADW); c. 11 miles [18 km] SSW, of Port Broughton, Blake 16848, 28.8.1946 (BRI); Hincks National Park, Symon 6455, 11.10.1968 (ADW); Kirton Point Reserve, Port Lincoln, Whibley 360 , 12.10.1958 (AD); Flora and Fauna Reserve, Hundred of Flinders, Specht 2636, 10.11.1960 (AD), Northern Lofty: c. $5 \mathrm{~km}$ W. of Bute (old Mona railway yard), Copley 494, 14.8.1966 (AD); South Hummocks Range, Copley 3228, 25.10.1970 (AD). Murray: 6 miles [10 km] W. of Murray Bridge, Crocker, 23.10.1943 (CANB); Kinchina, Cleland NSW 117042, 9.1922 (NSW). Yorke Peninsula: Point Davenport, Symon 11918, 4.11.1979 (ADW); between Arthurton \& Maitland, Blaylock 1046, 6.10.1968 (AD). Southern Lofty: Chaunceys Line Reserve, Hilton 1011, 9.10.1954 (ADW). Kangaroo Island: Kingscote, Cleland, 26.11.1945 (AD 96323204). South-eastern: Ki Ki, 30 miles [48 km] SE. of Tailem Bend, Hilton, 12.10.1953 (ADW).

WESTERN AUSTRALIA: Roe: $16 \mathrm{~km}$ from Gnowangerup, towards Albany, Phillips WA/622116, 10.10.1962 (NSW). Eyre: 4 km E. of Needilup. Newby 4919, 10.11.1975 (PERTH).

Differs from $S$. mundula in its intravaginal habit, rather finer, pubescent to hirsute leaves with the nerves manifest on the outer surface, its very obtuse rather than truncate ligule, more slender, capillary, and shorter awn, shorter glumes and lemma. The spikelets and lemmas of $S$. exilis resemble those of $S$. multispiculis but the short slender tufted habit of $S$. exilis is very different.

Although $S$. exilis and $S$. mundula as described are quite distinct, two specimens are difficult to place in one or the other of the taxa because of the combinations of the definitive characters: 'Kirton Point Reserve, Port Lincoln, Whibley 360, 12.10 .1958 (AD)' has smooth and \pm glabrous foliage as in $S$. mundula but a short lemma, delicate awn and slender, mostly intravaginal shoots as in S. exilis. 'Hincks National Park, Blue Range, Oak Amphitheatre, Alcock 2224, 7.12.1968, in part (AD)' has a long lemma, sturdy and pubescent awn and \pm glabrous foliage as in $S$. mundula but ribbed, slender, mostly intravaginal shoots as in $S$. exilis.

Both these specimens are from the area of overlapping distributions of $S$. mundula and $S$. exilis; their existence as intermediates does not affect the basic taxa. 
Stipa feresetacea J. Vickery, S.W.L. Jacobs \& J. Everett, sp. nov.

$S$. setaceae affinis, sed glumis brevioribus, flosculo calloque aristaque brevioribus differt.

Holotype: NORTHERn Territory: Mount Giles, 233'ㅇ's, 132 55'E, P.K. Latz 6605, 19.9.1976, Spreading perennial. Rare in skeletal soil, side of gully in shistoze [schistose] hill. (NT 51100; isotype NSW).

Caespitose perennial $0.5-1$ metre high, without rhizomes, with a basal tuft of leaves from half to the full height. Culms erect, terete, $0.4-1.2 \mathrm{~mm}$ wide near the base, \pm compressible, smooth to strongly ribbed upwards, glabrous to minutely scabrous upwards; nodes c. 3 , exserted, glabrous, to $75 \%$ wider than the adjacent internodes. Leaf sheaths not inflated, $2-4 \mathrm{~mm}$ wide, glabrous to minutely scabrous; basal sheath smooth to moderately ribbed, the innovations pubescent at the base; upper sheath moderately to strongly ribbed; margins glabrous. Ligule acute to acuminate, membranous, $3.5-8 \mathrm{~mm}$ long, not ciliate; abaxial surface glabrous to minutely scabrous; auricles \pm thickened, glabrous. Leaf blade tightly rolled, $0.7-0.9 \mathrm{~mm}$ wide, to $30 \mathrm{~cm}$ long; abaxial surface smooth to moderately ribbed, minutely scabrous; adaxial surface strongly ribbed, puberulous with minute siliceous prickles; margin minutely scabrous. Panicle 6-12 cm long, exserted, contracted, 5-10 mm wide (excluding awns), with distant fascicles of unequal, few-flowered, compound branches; axis angled, minutely scabrous; branches 1-25 mm long, angled, minutely scabrous; pedicels 2-7 mm long, angled, minutely scabrous. Spikelets 4-7 mm long (excluding awn), gaping at maturity. Glumes subequal to unequal, acute, straw-coloured, glabrous to minutely scaberulous; lower glume 4-7 mm long, lower $40-50 \% 3-$ nerved, upper 50-60\% 2-1-nerved; upper glume 4-6 mm long, lower $40-70 \%$ 5-3-nerved, upper 30-60\% 3-1-nerved. Floret turbinate, 3-4.5 mm long (including callus). Lemma surface granular to smooth, with hairs $0.5-1 \mathrm{~mm}$ long, without a neck; indefinite coma of hairs $0.2-0.9 \mathrm{~mm}$ long; lobes absent. Callus $0.7-1.4 \mathrm{~mm}$ long, weakly bent at the tip, densely sericeous with hairs $0.1-1 \mathrm{~mm}$ long. Awn 12-18 mm long, twice bent, $0.2 \mathrm{~mm}$ wide near the base; column $7-10 \mathrm{~mm}$ long, $3.5-6 \mathrm{~mm}$ to the first bend, brown, scabrous with hairs minute- $-0.1 \mathrm{~mm}$ long; bristle delicate, minutely scabrous. Palea equal to the lemma, obtuse, densely sericeous in the central groove with hairs $0.5-1 \mathrm{~mm}$ long, surface smooth to granular along the central groove. Lodicules $3 ; 2$ abaxial membranous, c. $0.8 \mathrm{~mm}$ long, acute; paleal membranous, c. $0.5 \mathrm{~mm}$ long, acute. Anthers $1.4-1.8 \mathrm{~mm}$ long, not penicillate. Caryopsis 2-2.5 mm long; embryo $30-40 \%$ the length; hilum $80-100 \%$ the length.

Similar to $S$. setacea but differing in all the spikelet parts being smaller. See notes under $S$. setacea concerning similarities with species of Piptochaetium.

The specific epithet is derived from the Latin for 'nearly' or 'almost' (fere) and from the specific epithet of $S$. setacea.

DistriBUTION: Rocky hillsides of the Central Australian Ranges.

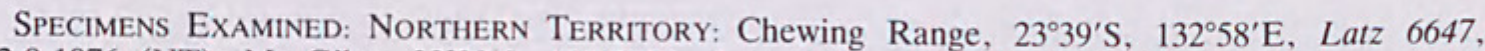
22.9.1976 (NT); Mt Giles, 23⒊' S, 132 55'E, Latz 6605, 19.9.1976 (NT, NSW); N. face of Mt Gillen, Latz 1808, 14.10.1971 (NT, CANB). 
Stipa flavescens Labill., Nov. Holl. Pl. 1: 24, pl. 30 (1804); non Nees in Lehm. (1846); Brown, Prodr.: 175 (1810), at least in part; Bentham, Fl. Austral. 7: 566 (1878); Hughes, Kew Bull. 1921: 11 (1921); Black, Fl. S. Austral. 1: 66 (1922). K).

HoLOTYPE: 'Stipa flavescens billard n. Holl' (FI-W!, dupl. G (poor specimen); probable isotype

SyNONYMS: $S$. scabra var. elatior Benth., Fl. Austral. 7: 571 (1878). TyPIfICATION, as cited (see below): 'Western Australia: Swan River, Drummond, Ist coll. and No. 959 (K); Murchison River, Oldfield'.

S. elatior (Benth.) Hughes, Kew Bull. 1921: 2 (1921); Black, Fl. S. Austral. edn 2: 91 (1943). Based on S. scabra var. elatior Benth. TYPIFICATION: Hughes cites: 'Western Australia, Swan River, Drummond 1st coll. and No. 959*; Harvey Steward 775; King Georges Sound, Brown 2603 p.p.'; by the asterisk she indicates Drummond 959 as the Type of $S$. elatior and, by implication, the Lectotype of S. scabra var. elatior Benth. Two sheets of Drummond No. 959 are at K(!) each named respectively in Bentham's and Hughes' handwritings. Duplicate specimens of this number are NSW 116766; MEL 59917, 59918.

S. scabra var. striata Benth., Fl. Austral. 7: 571 (1878). S. variabilis var. striata (Benth.) C. Gardner, Fl. W. Austral. 1, Gram.: 182 (1952). Typification, as cited (see below): 'Drummond, 133 (K!); Murchison River, Oldfield'. Gardner also cites, incorrectly, S. incurva Hughes and S. falcata Hughes as synonyms of the variety and cites 13 specimens from the South West Province of Western Australia (not seen and which may or may not be $S$. flavescens).

S. tenuiglumis Hughes, Kew Bull. 1921: 22 (1921); Black, Trans. \& Proc. Roy. Soc. S. Austral. 63: 241 (1939), Fl. S. Austral. edn 2: 90 (1943). REPLACED SYNONYM: S. scabra var. striata Benth. TYPIFICATION: Hughes cites five specimens: 'Murchison River, Oolingarra, Oldfield; Sand near Woodmans Point, Oldfield; Swan River, Drummond 133*, 138 p.p.; Buckland Hill, near Perth, limestone hills, Cecil Andrews, 1st coll. 1205,' indicating, by the asterisk, that Drummond 133 (K!) is the Type of her species and, by implication, the Lectotype of S. scabra var. striata Benth. At MEL there are probable duplicates of the Oldfield specimens from Woodmans Point and the Murchison River; these are also $S$. flavescens Labill.

S. compacta Hughes, Kew Bull. (1921): 24 (1921); 1922: 19 (1922); Willis, Handb. Pl. Victoria 1: 188 (1962), edn 2: 186, 435 (1970); Black, Fl. S. Austral. edn 2: 91 (1943). HolotYPE; TASMANIA: Gunn 996 p.p. (K!, CANB photo no. 237026).

S. aphanoneura Hughes, Kew Bull. 1921: 25 (1921); Black, Fl. S. Austral. edn 2: 93 (1943). Holotype: TASMANiA: Kents Group, Brown 6202 p.p. (K!, CANB photo No. 237025). We have been unable to discern any differences between $S$. aphanoneura Hughes and $S$. flavescens Labill. that could justify maintaining the former as a distinct species. In her description, Hughes states that the culms are pubescent, but in the Holotype they are not, and that the lateral nerves of the lower glume are almost obsolete, but in the Holotype they seem as distinct as in the rest of $S$. flavescens. Her illustration of a transverse section of a leaf of $S$. aphanoneura (fig. 37a, p. 29) clearly shows the difference in the indumentum (cf. fig. 6a, p. 19, S. flavescens) that can be readily observed on many specimens. We have, however, seen a number of intermediate specimens with a smooth outer surface of the blade and a pubescent upper surface, or vice versa, and specimens from a particular locality may be either glabrous or hairy. A manifest indumentum is more likely to occur in plants growing in habitats towards the limit of tolerance for the species (a not uncommon trend in grasses) such as on fossil sands (former sand dunes) now well away from the normal maritime or estuarine habitat of $S$. flavescens. S. aphanoneura then, is probably just a growth form of $S$. flavescens and is so treated here.

S. hirsuta Hughes, Kew Bull. 1921: 22 (1921). Holotype: Western Australla: Swan River, Drummond s.n., s.d. (K!) -S. scabra var. barbata Benth., Fl. Austral. 7: 571 (1878); based on same type.

S. pubescens var. maritima J. Black, Trans. \& Proc. Roy. Soc. S. Austral. 67: 36 (1943); Black, Fl. S. Austral. edn 2: 90 (1943). Holotype: South Australia: Marino, J.B. Cleland s.n., 8.10.1932 (AD 97422295).

Possible SynonymS: S. laeviculmis Nees in Lehmann, PI. Preiss. 2: 99 (1846). Holotype: cited as 'In insula Van Diemen?' We have not yet found a specimen that could be regarded as the Holotype but the description would seem to apply to $S$. flavescens. 
S. laevis Mez, Feddes Repert. Spec. Nov. Regni Veg. 17: 210 (1921). HolotypE: cited as 'Western Australia, Esperance (Diels)'. The Holotype was in B and is no longer extant. We have not seen any specimen that could reliably be regarded as a duplicate of the Type. The description is a reasonable match for $S$. flavescens.

Caespitose perennial to $0.8-1.2$ metres high with conspicuously extravaginal shoots from a short rhizome. Culms geniculate or erect, slightly compressible, terete, (1.5-) 3-4 mm wide near the base, scarcely ribbed, glabrous but sericeous just below the nodes, or puberulous to pubescent; nodes $2-4$, exserted, to $40 \%$ broader than adjacent internodes, sericeous to almost glabrous. Leaf sheaths at first tightly enveloping the culms, soon becoming loose, slightly ribbed to almost smooth, minutely puberulous or scaberulous between the nerves to glabrous or occasionally densely pubescent; upper sheaths usually glabrous; inner margin glabrous or ciliate just below the orifice; outer margin ciliate but glabrous at the base. Ligule firm and coriaceous, $0.3-0.6 \mathrm{~mm}$ long, truncate, ciliate; abaxial surface sericeous; auricles thickened and spreading, with a sparse to dense tuft of hairs below. Leaf blades usually flexuose, occasionally erect, tightly rolled to expanded, to $7 \mathrm{~mm}$ wide, to $70 \mathrm{~cm}$ long; abaxial surface not ribbed, puberulous to glabrous or scaberulous, occasionally hirsute or scabrous with long hairs or short hooks; adaxial surface ribbed, scaberulous with minute hairs, or glabrous or rarely sparsely to densely hirsute especially in the basal shoots; margin similar to adaxial surface. Panicle (10-) 20-30 (-40) cm long, c. $3 \mathrm{~cm}$ wide (excluding awns), exserted late in development, contracted to loosely spreading, usually dense with moderately close fascicles of usually many-flowered branches; axis terete to angular upward, scaberulous to \pm glabrous; branches to $15 \mathrm{~cm}$ long, terete to angular, scaberulous; pedicels to $8 \mathrm{~mm}$ long, terete to angular, scaberulous. Spikelets 9-14 (-16) mm long (excluding awn), gaping. Glumes unequal, membranous and translucent, scaberulous to scabrous or glabrous on the nerves or occasionally scaberulous overall; lower glume 9-14 (-16) mm long, long- to short-acuminate, the lower 25-70\% 3-nerved; upper glume 9-11 (-14) $\mathrm{mm}$ long, the lower $30-50 \% 5$-nerved, 3-nerved to $70 \%$. Floret cylindrical to narrow-fusiform or slightly turbinate, (5.5-) 7-9 mm long (including callus). Lemma granular, dark brown at maturity, with sparse, spreading, erect yellow hairs becoming deep golden-brown at maturity; coma $0.3-1.2 \mathrm{~mm}$ long; $1-2$ lobes, $0.1-0.5 \mathrm{~mm}$ long. Callus $1.6-3 \mathrm{~mm}$ long, fine and straight, sericeous with hairs similar to those of the lemma. Awn 40-70 mm long, 0.2-0.25 mm wide near the base, twice bent; column $18-30 \mathrm{~mm}$ long, $10-15 \mathrm{~mm}$ to the first bend, densely and softly pubescent with hairs (0.2-) $0.25-0.4 \mathrm{~mm}$ long; bristle scaberulous. Palea to $0.7 \mathrm{~mm}$ shorter than the lemma, acute, coriaceous, sericeous down the centre; margins glabrous; tip ciliate. Lodicules 3, membranous; 2 abaxial $0.8-1.6 \mathrm{~mm}$ long, spathulate; paleal c. $0.5 \mathrm{~mm}$ long, triangular, narrow-acute. Anthers $1.5-3.5 \mathrm{~mm}$ long, lightly penicillate. Caryopsis $3.5-4 \mathrm{~mm}$ long; embryo $25 \%$ the length; hilum $75 \%$ the length.

DISTRIBUTION: Headlands and sandy soils close to the coast of all southern States, including New South Wales.

Selected Specimens: New South Wales: South Coast: Cave Beach, 3 miles [4.8 km] SW. of Jervis Bay, Coveny 3679, 12.10.1971 (NSW); Brush Island, 15 miles [24 km] S. of Ulladulla, Rodway, 5.9.1937 (K); Batehaven, Reiner 471, 22.11.1960 (CANB); Malua Beach, Phillips CBG 067213, 18.11.1967 (CBG); Broulee Head between Batemans Bay \& Moruya, Rodway NSW $116722,19.12 .1948$ (NSW).

VICTORIA: Region D: Hamilton Native Plant Reserve, Wannon, Corrick 1570, 2.1.1969 (Corrick herb). Region E: Steep limestone cliffs of Lower Glenelg River at Moretons Hut, Willis, 29.10.1948 (MEL); Portland, Beauglehole 7888, 10.1949 (NSW); Port Fairy, Symon 141, 8.11.1959 (ADW) 
Region K: c. 24 km N. of Nelson, Beauglehole 55340, 6.12.1976 (ACB, NSW); E. of Port Campbell, Beauglehole 21609, 31.10.1966 (NSW); Apollo Bay, Corrick 3783, 12.12.1973 (Corrick herb). Region N: Loddon, Walter, 11.1887 (MEL); Seaholme, Williamson, 1.11.1930 (MEL); Yarra, Mueller, 1852 (MEL). Region P: Seaford, Muir 31, 28.12.1956 (MEL); Point Addis near Anglesea, Nelson ANU 16320, 1.1972 (CANB); Westernport, Corrick 2964, 12.12.1972 (Corrick herb); Phillip I. in Westernport Bay, Vickery NSW 116727, 7.11.1973 (NSW), Region T: Wilsons Promontory, Muir 627, 15.12.1958 (MEL). Region Z: 2.5 miles [4 km] NW. of Mallacoota, Beauglehole 32113, 26.11.1969 (NSW.

Tasmania: Deal Island, Kents Group, Whinray 48, 29.2.1968 (NSW); King Island, Blake 18437, 27,1.1949 (BRI, NSW); Cape Barron Island, Furneaux Group, Whinray 419, 22.5.1969 (MEL); Tomahawk, Townrow 112, 12.1967 (JEST); Hobart, Old Beach, Townrow 94, 12.1967 (JEST); Marion Bay, Hemsley 6683, 3.1.1972 (NSW); South Arm, Opossum Bay, Townrow 42, 11.1967 (JEST); North Bruny I., Variety Bay, Townrow 157, 1.1968 (JEST); The Neck, Bruny I., Phillips 787, 29.11.1965 (CBG).

South Australia: Eyre Peninsula: Fowlers Bay, Rogers NSW 116728, 9.1907 (NSW); Morialta, Hilton NSW 116966, 23.11.1953 (NSW dupl. of ADW); 2 miles [3 km] from Smokey Bay, Hilton, 25.8.1955 (ADW 197773); St Francis I., c. $60 \mathrm{~km}$ SW. of Ceduna, Wace 128, 8.1.1971 (NSW); Isles of St Francis, Masillon Island, Wace 294, 5.10.1972 (AD); Isles of St Francis, Fenelon Island, Wace 279, 5.10.1972 (AD); Elliston, c. 150 km NW. of Port Lincoln, Cleland, 21.8.1925 (AD); Beaumont, Smith 1527, 18.10.1968 (AD); Boston Island near Port Lincoln, Wilson 303A, 8.10.1958 (AD); Port Lincoln, French, 9.1954 (ADW); c. $15 \mathrm{~km}$ SSE. of Port Lincoln, Specht 2634, 10.11.1960 (AD); Sleaford Mere, Alcox 3288, 3.11.1970 (ADW, AD). Northern Lofty: $40 \mathrm{~km} \mathrm{~S}$. of Port Wakefield, Tindale NSW 116980, 10.9.1970 (NSW). Murray: Murray Bridge, Cleland, 14.10.1949 (AD). Yorke Peninsula: Wool Bay, c. 10 miles [16 km] N. of Edinburgh, Lothian 1133, 7.10.1962 (AD, NSW); c. $15 \mathrm{~km}$ SSE. of Minlaton, Blaylock 1554, 10.10.1970 (AD); 8 miles [13 km] SSW. of Corny Point Lighthouse, Blaylock 1074, 13.10.1968 (AD); inland from Stenhouse Bay township, Symon 9550A 6.10.1974 (ADW). Southern Lofty: Valley View near Dry Creek, Spooner 1257, 23.10.1970 (AD); Highbury, Smith 1524, 10.4.1968 (AD); Hindmarsh I., no collector, 10.10.1945 (AD); Walkerville cemetery, Cleland, 3.10.1955 (ADW 13283); Seaton Golf Course c. 9 km WNW. of Adelaide, Smith 1443, 7.10.1968 (AD); Heywood Park, Millswood, Kraehenbuehl 827, 26.10.1962 (AD); Waite Agricultural Research Institute, Hilton NSW 116967, 22.10.1953 (NSW, dupl. of ADW); Wayville near Adelaide, Hilton NSW 116970, 29.9.1946 (NSW, dupl. of ADW); Henley Beach, Cleland, 4.11.1932 (AD); between Glenelg \& Brighton, Black, 16.10.1906 (AD); National Park, Belair, Ising, 26.11.1932 (ADW 44008); Brighton, Hilton, 1.1944 (ADW); Hallett Cove, Cleland, 29.9.1932 (AD), Cooper, 16.10.1964 (AD); between Hackham \& Noarlunga, Smith 788, 31.10.1967 (AD); Port Noarlunga, Cleland, 5.11.1926 (K); W. of Hackham, Cleland, 28.10.1933 (AD); c. $0.5 \mathrm{~km}$ inland from Blanche Point, Smith 363, 22.9.1967 (AD); cliffs at Pt. Willunga near Aldinga, Hilton, 20.10.1946 (ADW 43879); Sellicks Beach, Cleland, 18.10.1941 (AD); Aldinga Bay Scrub, Cleland, 30.10.1928 (AD); Finniss to Milang road c. $3 \mathrm{~km}$ from Finniss, Spooner 2554, 8.10.1972 (AD); Normanville, 2 miles [3 km] W. of Yankalilla, Hilton, 10.10.1946 (ADW); Goolwa, Cleland, 10.10.1945 (AD); Murray Mouth, Hilton, 9.10.1954 (ADW); Port Elliot, 4 miles [6 km] NE. of Victor Harbor, Hilton NSW 116746, 10.10.1945 (NSW, ADW); Halls Creek, c. $5 \mathrm{~km}$ W. of Victor Harbor tributary of the Inman River, Cleland, 15.11.1930 (AD); Mouth of Inman River, Cleland, 12.1.1940 (AD); Encounter Bay, Cleland, 9.1.1941 (ADW); Callawonga Creek, Hilton, 25.11.1953 (ADW 44120); Waitpinga Beach, $13 \mathrm{~km}$ WSW. of Victor Harbor, Crisp 945, 27.10.1974 (CBG, NSW). Kangaroo Island: Kingscote, Cleland, 19.9.1955 (AD); Penneshaw, Hilton (ADW); Rocky River, Cleland, 27.11.1954 (AD); mouth of South-West River, Cleland, 27.1.1940 (AD). Southeastern: near Narrung, E. of the Coorong, Cleland, 17.11.1953 (AD); Campbell Park, Cleland, 16.10.1955 (AD); Bagshaws turnoff near Meningee, $8 \mathrm{~km} \mathrm{E.} \mathrm{of} \mathrm{Princes} \mathrm{Highway,} \mathrm{Crisp} \mathrm{524,}$ 1.9.1973 (CBG); $8.7 \mathrm{~km}$ on Cape Jaffa road from Kingston-Robe road, Pearce 18, 9.2.1974 (ADW); Big Heath National Park c. 25 km SW. of Naracoorte, Weber 1671, 3.11.1969 (AD); 1 km E. of Robe, Crisp 3668, 7.12.1977 (CBG); Cape Buffon, Rivoli Bay, Cleland, 24.2.1946 (AD); near Millicent, Cleland, 13.10.1949 (AD); Myora Forest area, c. 16 km ENE. of Mt Gambier, Wilson 704, 11.12.1966 (CANB); Pt MacDonnell, Cleland, 31.10.1941 (AD); near Tantanoola Caves, Cleland, 28.2.1947 (AD); Hoods Drift c. 14 km W. of Mt Schank, Cleland, 17.2.1948 (AD); Cape Northumberland, Cleland, 1.11.1941 (AD).

Western Australia: Eucla: 3.5 miles [6 km] E. of Eucla, George 8516, 15.10.1966 (PERTH). Irwin: Dongara [as Dongarra], Maiden NSW 116760, 10.1909 (NSW); Cockleshell Gully, Gardner 8402, 15.10.1946 (PERTH); Murchison R., Oldfield (MEL 59921) (probable duplicate of a specimen cited by Hughes as $S$. tenuiglumis Hughes). Darling: southwards from New Norcia, Gardner 8665, 10.1947 (PERTH); City Beach, 7.5 miles [12 km] W. of Perth, Willis, 14.9.1947 (MEL 60670); Perth to Wanneroo, Salasoo 4169, 24.9.1970 (NSW); Kings Park, Perth, Gardner 861, 30.10.1920 
(PERTH); In arenosis sylvae prope Pine-Apple, Perth, Preiss 1826, 10.1831 (CBG, see also photo in NSW 116948, dupl. MEL 60038, LD, HBG); Karrakatta, Fitzgerald NSW 11676, 11.1900 (NSW); Cottesloe, Fitzgerald NSW 116766, 9.1901 (NSW); N. of Claremont, Fitzgerald NSW 150902, 26.9.1902 (NSW, PERTH); Claremont, Gardner NSW 150899, 9.1920 (PERTH); Catherine Beach, Rottnest, Green, 14.11:1956 (PERTH); Melville, 8 miles [13 km] S. of Perth, Turvey NSW 116769, 18.9.1965 (NSW); Fremantle to Kevinana, Salasoo 4016, 20.9.1970 (NSW); Woodman Pt, Oldfield, (MEL 59919) (presumably a duplicate of a specimen cited by Hughes as $S$. tenuiglumis Hughes); Yallingup, Maiden NSW 116765, 10.1909 (NSW). Eyre: North Twin Peak I., Recherche Archipelago, Willis NSW 150901, 20.11.1950 (PERTH, NSW).; 4 km E. of Needilup, Newbey 4919, 10.11.1975 (PERTH); John Cove, Bremer Bay, Newbey 4479, 8.10.1974 (PERTH).

Bentham cited Preiss no. 1826 under S. scabra var. occidentalis Benth. and cited $S$. flavescens Nees non Labill, as a synonym. Preiss no. 1826 in LD and HBG is actually $S$. flavescens Labill. although differing a little from the majority of specimens in having a rather widely spreading inflorescence. The awns are very slender, delicate and loosely twice bent as in $S$. flavescens, not stout, strongly falcate and with a long bristle as in S. tenuifolia (syn. S. scabra var. occidentalis).

Stipa gibbosa J. Vickery, Telopea 2: 14 (1980).

Holotype: South Australia: Burnside district, Beaumont Common, c. $6 \mathrm{~km}$ SE. of Adelaide, J.B. Cleland, 11.10.1942 (AD 9632316).

Caespitose perennial to 1.5 metres high with a sparse basal leaf tuft to $30 \mathrm{~cm}$. Culms erect, terete, not compressible, $1.5-2.5 \mathrm{~mm}$ wide near the base, ribbed, glabrous to scaberulous. Nodes $2-3$, exserted, $35-60 \%$ wider than adjacent internodes, densely pubescent with slightly spreading short hairs. Leaf sheaths at first tightly enveloping the culms, finally becoming loose, 3-6 mm wide, strongly ribbed, glabrous except densely pubescent to puberulous just above the node; inner margin ciliate just below the orifice; outer margin ciliate. Ligule thinly coriaceous, truncate, ciliate, $0.3-0.5 \mathrm{~mm}$ long, although continuous with the sheath margins producing two lobes to $1 \mathrm{~mm}$ long, themselves ciliate with a tuft of hairs to $2 \mathrm{~mm}$ long; abaxial surface sericeous; auricles thickened and spreading, glabrous. Leaf blades flat or convolute to $30 \mathrm{~cm}$ long, $2-5 \mathrm{~mm}$ wide; adaxial surface very strongly ribbed, minutely puberulous, occasionally with widely scattered hairs; abaxial surface minutely puberulous or strongly scabrous with minute hairs especially on the basal leaves, occasionally with widely scattered hairs; margins similar to adjacent surface. Panicle to $30(-40) \mathrm{cm}$ long, exserted, moderately sparse with moderately closely-spaced fascicles of unequal, few-flowered, compound branches, contracted, 1.5-2 (-5) $\mathrm{cm}$ wide (excluding awns); axis terete, upwards flattened and scabrous, mostly on the edges; branches to $9 \mathrm{~cm}$ long, flattened, scabrous mostly on the edges; pedicels 4-10 mm long, flattened, scabrous mostly on the edges. Spikelets $11-17 \mathrm{~mm}$ long (excluding awn), gaping widely at floret disarticulation, otherwise the tips tightly closed. Glumes unequal, firm and green or yellow for most of the length, the tip membranous and white, acute to acuminate, broad and inflated at the middle, glabrous with only the nerves scabrous, or scaberulous to scabrous with dense minute hairs overall; lower glume 11-17 mm long, lower 75\% 3-nerved; upper glume 8-13 mm long, lower 50-30\% 5-nerved, lower 75\% 3-nerved. Floret $4.5-6.0 \mathrm{~mm}$ long (including callus), oblong-cylindrical with a short, slightly defined neck, gibbous with a strongly eccentric awn. Lemma red-brown to almost black at maturity, surface strongly granular, with spreading white to yellow hairs, becoming golden at late maturity, the central nerve thickened; lobes absent; coma of spreading hairs, $0.8-1.3 \mathrm{~mm}$ long. Callus sturdy, slightly curved, $1-1.5 \mathrm{~mm}$ long, with hairs slightly darker than those of the lemma, the 
naked point (0.15-) 0.2-0.5 mm long, and squared. Awn 25-35 (-50) mm long, twice bent, $0.3 \mathrm{~mm}$ wide near the base; column $12-20 \mathrm{~mm}$ long, $5-8 \mathrm{~mm}$ to the first bend, scabrous with slightly spreading hairs less than $0.2 \mathrm{~mm}$ long; bristle scabrous. Palea \pm equal to the lemma or to $0.5 \mathrm{~mm}$ longer, thickly coriaceous to the margins, granular down the centre, flat or slightly depressed between the nerves, glabrous, \pm mucronate with the apex tightly convolute and slightly recurved, the tip usually penicillate. Lodicules 3 , membranous; 2 abaxial $0.8-1.3 \mathrm{~mm}$ long, oblong to narrow-cuneate; paleal $0.5-0.8 \mathrm{~mm}$ long, oblong to acute. Anthers $2.5-3 \mathrm{~mm}$ long, penicillate. Caryopsis c. $3.5 \mathrm{~mm}$ long, slightly gibbous above; embryo $30 \%$ the length; hilum $75 \%$ the length.

Distribution: South-western New South Wales, north-western Victoria and the Northern Lofty and Southern Lofty Regions of South Australia.

Selected Specimens: New South Wales: South Western Slopes: Urangeline, Newman NSW 117014, 21.11.1955 (NSW). South Western Plains: $29 \mathrm{~km} \mathrm{S.} \mathrm{of} \mathrm{Deniliquin,} \mathrm{Lloyd} \mathrm{NSW} 151487$, 7.11.1979 (NSW).

Victoria: Region C: 4-7 km from Dimboola toward Nhill, Canning 2972, 11.11.1969 (CBG 067316 p.p.). Region J: Cockajemmy Lakes, Beauglehole 61614, 17.11.1978 (ACB). Region N: 1 mile [1.5 km] S. of Laverton, Cullimore 125, 22.11.1967 (AD, PERTH).

South AUSTRAl.IA: Northern Lofty: Bundaleer Hills [c. $60 \mathrm{~km}$ SW. of Port Pirie], Black, 23.11.1925 (AD); Bundaleer, c. $41 \mathrm{~km} \mathrm{~N}$. of Clare, Cleland, 28.11.1930 (AD 96323249); Spalding, Black, 21.11.1925 (AD); c. 91 miles [146 km] E. of Snowtown Hospital, Copley 987, 25.12.1966 (AD); E. of Mortlock Research Station, Mintaro, Symon 3930, 16.12.1965 (ADW, CANB, NSW). Southern Lofty: Adelaide Agricultural High School, 7.11.1932 (ADW); Beaumont Common, c. 6 km SE. of Adelaide, Cleland, 23.10.1935 (AD 96323196); Halls Creek, Encounter Bay, Cleland H70, 16.11.1930 (K).

From $S$. aristiglumis it differs in the distinctly dorsally gibbous floret (instead of \pm uniformly fusiform narrowing evenly towards the apex) and in usually being a smaller plant. From $S$. blackii it differs in the very short coma of hairs at the apex of the lemma and more distinctly gibbous lemma. From $S$. setacea it differs in the truncate ligule, short \pm obtuse callus, and palea not deeply furrowed down the back.

Stipa hemipogon Benth., Fl. Austral. 7: 569 (1878); Hughes, Kew Bull. 1921: 18 (1921), ibid. 1922: 18 (1922); Gardner, Fl. W. Austral. 1, Gram.: 178, 181, fig. (1952).

Typification: Bentham cited 'W. Australia, Drummond, no. 231, 376', specimens at K. Hughes (1921) cites 'Swan River, Drummond 231, 376*' and, by her use of the asterisk, has selected Drummond 376 as the Lectotype. A duplicate of Drummond 376 is at MEL. Mueller, Fragm. 8: 104 (1875), regarded Drummond 376 (the Lectotype of $S$. hemipogon) as only a variety of $S$. semibarbata ('Varietas brachyathera') but supplied no separate description; he also wrote this nomen nudum on MEL 59933.

Synonyms: $S$, nobilis Pilger in Diels \& Pritzel, Bot. Jahrb. Syst. 35: 70 (1904). Typification: Pilger cited 'Coolgardi pr. Bronti inter frutices in arenosis frequens atque insignis'. His specimen was doubtless at B and presumably has been destroyed. At MEL there is a specimen (MEL 59967) from the Berlin Herbarium which is stated thereon to be part of the Type of $S$. nobilis Pilger and is annotated 'W. Australia: Dist. Coolgardi; Bronti. Diels $n .5611$ ' and this is here designated as the Lectotype.

S. indeprensa J. Black, Trans. \& Proc. Roy. Soc. S. Austral. 65: 334 (1941); Black, Fl. S. Austral. edn 2: 90 (1943). Holotype: South Australia: Minnipa, Eyre Peninsula, J.M. Black, 11.11.1915 (AD 97403332; isotype MEL 59951). Willis, Handb. PI. Victoria 1: 184-(1962) and edn 2: 184 (1970), regarded $S$. indeprensa as a synonym of $S$. hemipogon but included also $S$. plagiopogon J.M. Black (=S. mollis R. Br.). See also Eichler, Suppl. Black's Fl. S. Austral.: 49 (1965). 
S. semibarbata var. gracilis J. Black, Trans. \& Proc. Roy. Soc. S. Austral. 67: 36 (1943); Fl. S. Austral. edn 2: 89 (1943). TYPIFICATION: Black cited two localities, Mount Lofty Range and Kangaroo Island, when establishing the name. In his Flora of South Australia he added a third locality, Encounter Bay. All three are represented in Black's collections held at AD, and have been named $S$. semibarbata var. gracilis by Black.

(i) 'Mt Lofty Range, National Park, Belair, J.B. Cleland, 26.11.1932' (AD 97244093). The specimen consists of a small tuft of basal leaves attached to the rootstock and a single culm with panicle now devoid of florets. Three florets have been attached to the sheet. The lemmas are $7-8 \mathrm{~mm}$ long, the column $25 \mathrm{~mm}$ long with spirally arranged hairs, and the glumes $\mathrm{c}$. $20 \mathrm{~mm}$ long. We would confirm a previous identification of this specimen by J. E. S. Townrow as Stipa mollis R. Br. A probable duplicate derived from Cleland's herbarium and annotated 'National Park, 26.11.1932' (AD 96323321) is certainly S. mollis. The present condition of this Syntype makes it undesirable to select it as the Lectotype.

(ii) 'Kangaroo Island, near Vivonne Bay, J.B. Cleland, 11.1924' (AD 97244091). The specimen consists of a single culm complete to the base but with only a small tuft of basal leaves and a single panicle in good condition with many florets still attached. We here designate this specimen as the Lectotype of the variety. The lemmas are c. $6 \mathrm{~mm}$ long, the column c. $15 \mathrm{~mm}$ long with spirally arranged hairs, and the glumes $15-17 \mathrm{~mm}$. The specimen agrees with Stipa hemipogon Benth., as does an apparent duplicate (AD 96323160).

(iii) 'Encounter Bay, J.B. Cleland, 17.11.1930' (AD 97244092). As this sheet was not cited with the original Latin description it is not eligible for selection as Lectotype though it was designated as such by Townrow in Pap. \& Proc. Roy. Soc. Tasmania 112: 242 (1978). We confirm Townrow's identification of this specimen as Stipa mollis $\mathrm{R}$. Br.

Caespitose perennial to 1 metre high, not rhizomatous, with a basal tuft of leaves a third to half the height. Culms erect or geniculate at the base, terete, 2-2.5 mm wide near the base, not compressible, not ribbed, minutely scaberulous; nodes $2-5, \pm$ exserted, not swollen. Leaf sheaths not inflated, $0.5-1 \mathrm{~mm}$ wide; basal sheath very slightly ribbed, scaberulous between the nerves with hairs minute $(-0.3 \mathrm{~mm}$ long), inner margin glabrous, outer margin ciliate with hairs minute $-0.2 \mathrm{~mm}$ long; upper sheath moderately ribbed, scabrous along the centre with minute tubercles or scaberulous, edges glabrous to sparsely pilose, inner margin glabrous, outer margin ciliate with hairs $0.1-0.3 \mathrm{~mm}$ long to glabrous; collar of hairs $1 \mathrm{~mm}$ long. Ligule truncate, membranous, (0.3-) $1.5-3 \mathrm{~mm}$ long, ciliate with hairs $0.4-0.6 \mathrm{~mm}$ long; abaxial surface sericeous with hairs (0.2-) 0.6-0.9 mm long; auricles absent. Leaf blade linear, weakly rolled, $1.5-3 \mathrm{~mm}$ wide, to $20 \mathrm{~cm}$ long; abaxial surface moderately ribbed, the surface scabrous between the nerves with minute tubercles, sometimes also with sparse hairs $0.4 \mathrm{~mm}$ long; adaxial surface strongly ribbed, with hairs $0.2-0.6 \mathrm{~mm}$ long; margins scabrous with minute stiff hairs. Panicle $10-25 \mathrm{~cm}$ long, exserted, with moderately close fascicles of unequal, few- to many-flowered, compound branches, contracted, 1-3 cm wide (excluding awns); axis \pm terete, scaberulous; branches $2-5 \mathrm{~cm}$ long, slightly angled, scabrous with hairs minute $-2.5 \mathrm{~mm}$ long; pedicels $2-10 \mathrm{~mm}$ long, angled, scabrous with hairs minute $-2.5 \mathrm{~mm}$ long. Spikelets $15-20 \mathrm{~mm}$ long, gaping at maturity. Glumes unequal, acute to acuminate, scaberulous to almost glabrous; lower glume $15-20 \mathrm{~mm}$ long, lower $45-50(-85 \%)$ 3-1-nerved; upper glume 10-16 mm long, lower 30-40\% 5-nerved, upper $60-70 \%$ 3-1-nerved. Floret cylindrical, without a neck, 5-7.5 mm long (including callus). Lemma reddish brown at maturity, the surface smooth to granular upwards, sericeous with hairs $0.3-0.7 \mathrm{~mm}$ long, white to golden at maturity; lobes and coma absent. Callus $1.5-3 \mathrm{~mm}$ long, weakly bent at the tip, densely sericeous with hairs $0.2-0.8 \mathrm{~mm}$ long, white to gold at maturity. Awn $30-60 \mathrm{~mm}$ long, twice bent, $0.2-0.3 \mathrm{~mm}$ wide near the base; column $10-20 \mathrm{~mm}$ long, c. $10 \mathrm{~mm}$ to the first bend, brown to straw-coloured, densely plumose with hairs $0.5-4 \mathrm{~mm}$ long, the hairs produced on one side of the column, spiralling 
with it; bristle delicate, brown, scabrous but plumose at the base on one side with hairs $0.2-2 \mathrm{~mm}$ long similar to those of the column. Palea \pm equal to the lemma, acute, the surface granular to smooth, sericeous along the centre with golden hairs $0.4-1 \mathrm{~mm}$ long. Lodicules 2, abaxial, $1-1.5 \mathrm{~mm}$ long, obtuse. Anthers c. 1-1.5 mm long, not penicillate. Caryopsis 3-4 mm long; embryo $20 \%$ the length, hilum $80-100 \%$ the length.

DISTRIBUTION: Southern regions of South Australia and Western Australia, and western Victoria.

Selected Specimens: Victoria: Region J: near Stawell, Gauba CBG 047573, 21.10.1952 (CBG).

South Australia: Eyre Peninsula: Hundred of Hambidge, NE. of Lock, Specht 2460, 8.11.1960 (AD); Yeelanna, 10 miles [16 km] N. of Cummins, Hilton NSW 116486, 20.12.1945 (ADW, NSW); Hundred of Tooligie, c. $85 \mathrm{~km} \mathrm{~N}$. of Port Lincoln, Kuchel 1422, 23.10.1963 (AD). Murray: Alawoona, Cleland.NSW 116491, 12.1913 (NSW, AD); Peebinga Wild Life Reserve, c. 80 km SSE. of Renmark, Cleland, 23.4.1963 (AD); W. of Murray Bridge, Crocker, 23.10.1943 (CANB 12173); Kinchina, Wood, 9.1939 (ADW 3969); Swanport, Story, 4.11.1870 (MEL 60826). Southern Lofty: Finniss, Eardley, 3.1.1935 (ADW 277 in part). Kangaroo Island: Stokes Bay Road, Cleland, 30.10.1967 (AD); American River, Cleland, 25.10.1967 (AD); between Kingscote \& American River, Hilton, 7.1.1945 (ADW 44182); MacGillivray, Crocker, 22.11.1941 (ADW 4334).

Western Australia: Eucla: c. 57 km SE. of Madura, Parsons 97, 29.11.1967 (AD); c. 23 km SSW. of Cocklebiddy, Parsons 154, 1.12.1967 (AD). Coolgardie: Campion, Gardner 2768, 29.9.1931 (PERTH); Parker Range, Merrell, 1890 (MEL); Higginsville, O'Donnell NSW 150910, 1942 (PERTH); 1 mile [1.6 km] from Salmon Gums, Phillips CBG 018938, 6.11.1972 (CBG). Irwin: 23 miles [37 km] N. of Geraldton in Oakabella Hills, Burbidge, 2.9.1947 (CANB 15285); between Geraldton \& Northampton, Blake 18094, 2.9.1947 (BRI, PERTH). Avon: 5.3 miles [8.5 km] from Wubin toward Wongan Hills, Canning 2921, 13.9.1968 (CBG); Cowcowing, Koch 1132, 9.1904 (NSW, PERTH, K); Yorkrakine, Gardner NSW 150908, 9.1936 (PERTH, NSW); 17 miles [27 km] E. of Pingelly, Aplin 775, 10.1960 (PERTH); 15 miles [24 km] S. of Tammin, Royce 9359, 3.11.1970 (PERTH); Wickepin, Wallace NSW 150909, 2.1923 (PERTH). Darling: $20 \mathrm{~km}$ from Keenan College towards New Norcia, Ollerenshaw \& Carriage CBG 062571, 4.10.1975 (CBG); 14 miles [22 km] from Gingin towards Regans Ford, Phillips CBG 043728, 28.9.1968 (CBG); Kings Park, Perth, Carne NSW 150906, 18.10.1923 (PERTH); South Perth, Carne NSW 150907, 1.12.1924 (PERTH); Inglewood, North Perth, Gardner NSW I50911, 11.1933 (PERTH); 46 miles [74 km] from Perth along Albany Highway, Phillips CBG 043574, 30.9.1968 (CBG); Porongorup, Maiden NSW 116934, 11.1909 (NSW); Albany, Maiden NSW 116463, 11.1909 (NSW). Eyre: Ninety Mile Tank, Lake King - Norseman Track, Hopkins \& Robinson NSW 150904, 11.1978 (PERTH); One Mile Rocks Reserve SE. of Lake King, George 10468, 12.11 .1970 (PERTH); 21 miles [34 km] from Ravensthorpe towards Lake King, Canning NSW 116458, 5.11.1968 (NSW, BRI, dupl. of CBG); Desmond near Ravensthorpe, Maiden NSW 116462, 11.1909 (NSW, K); between Jerramungup \& Ravensthorpe at West River Crossing, Canning 7553, 10.11 .1968 (CBG); c. $21 \mathrm{~km}$ NNW, of the coast at Stokes Inlet, Orchard 1668, 20.10.1968 (PERTH); Esperance, Maiden NSW 116464, 11.1909 (NSW); c. 69 miles [110 km] from Esperance towards Ravensthorpe, Canning 7092, 1.6.1971 (CBG); Fitzgerald National Park, near Fitzgerald River, George 10556, 18.12.1970 (PERTH); Cape Arid National Park, E. of Esperance, Royce 9932, 1.12.1971 (PERTH); Cape Le Grand National Park, Royce 8717, 21.10.1969 (PERTH). Stirling: $61.2 \mathrm{~km}$ from Gnowangerup towards Albany, Phillips CBG 054856, 10.10.1962 (CBG); Frankland River W. of Cranbrook, Hadley NSW 150912, 12.1945 (PERTH); c. 35 miles [56 km] from Albany towards Borden via Chester Pass, Canning CBG 042828, 25.10.1968 (CBG).

Hughes (Kew Bull. 1921: 19 (1921) and 1922: 18 (1922)) apparently did not see the Type of $S$. nobilis Pilger, and her identification of a Victorian specimen with this species and her comments comparing $S$. nobilis with $S$. mollis and $S$. semibarbata have hence proved somewhat confusing. She cites Drummond 116 as $S$. nobilis.

Willis, Handb. Pl. Victoria 1: 184 (1962), edn 2: 184 (1970), appears to have erroneously identified Victorian specimens of $S$. mollis as $S$. hemipogon of Western Australia. Reference is made to his comments by Eichler, Suppl. Black's Fl. South Australia: 49 (1965). 
*Stipa hyalina Nees, Agrost. Bras.: 378 (1829); Hitchcock, Contr. U.S. Natl. Herb. 24: 277 (1925); Caro, Kurtziana 3: 56 (1966); Rosengurtt, de Maffei et de Artucio, Gram. Uruguayas: 77 (1970).

Holotype: 'Habitat ad Monte Video (Sellow. - Vidi in Hb. Reg. Berol.)'. The Type was Sellow $636 d$ in B which is no longer extant. There are two sheets marked "Brasilia Sello", apparently duplicates of the type, in US and these have formed the basis of our typification.

Caespitose perennial to c. 0.75 metres high, with a basal tuft of leaves, without rhizomes. Culms erect or slightly geniculate at the base, terete, c. $1 \mathrm{~mm}$ wide near the base, \pm compressible, moderately to slightly ribbed upwards, glabrous; nodes 3-4, exserted, glabrous, not swollen. Leaf sheaths at first tightly enveloping the culm, later becoming slightly free, glabrous and smooth; basal sheath 4-6 mm wide, slightly ribbed, moderately ribbed on the innovations; upper sheath $2-5 \mathrm{~mm}$ wide, strongly ribbed; margins glabrous. Ligule truncate, membranous, $0.2-2 \mathrm{~mm}$ long, glabrous; auricles thickened, $0.5-1.5 \mathrm{~mm}$ long, with tufts of hairs at the base on the innovations, glabrous elsewhere. Leaf blade expanded or loosely rolled, $1.5-4 \mathrm{~mm}$ wide, to $25 \mathrm{~cm}$ long; abaxial surface strongly ribbed, smooth and glabrous; adaxial surface strongly ribbed, smooth and glabrous to scaberulous with minute tubercles; margins scabrous with minute tubercles or sparsely ciliate with hairs to $0.2 \mathrm{~mm}$ long. Panicle $15-25 \mathrm{~cm}$ long, exserted, with distant fascicles of unequal, few-flowered compound branches, contracted, 2-4 cm wide (excluding awns); axis angular, scabrous with hairs minute- $-0.2 \mathrm{~mm}$ long; branches $2-6 \mathrm{~cm}$ long, angular, scabrous with stiff hairs minute- $-0.2 \mathrm{~mm}$ long; pedicels $0.5-5 \mathrm{~mm}$ long, angular, scabrous, with stiff hairs minute- $-0.2 \mathrm{~mm}$. Spikelets $9 \mathrm{~mm}$ long, gaping. Glumes unequal, acute to acuminate, hyaline, minutely scaberulous; lower glume $9 \mathrm{~mm}$ long, lower 10-30\% 3-nerved; upper glume $7-8 \mathrm{~mm}$ long, lower $40-50 \% 3$-nerved. Floret $4 \mathrm{~mm}$ long (including callus), cylindrical with a weakly defined neck. Lemma surface scabrous with minute crystalline tubercles, sericeous along the midrib with white hairs c. $0.7 \mathrm{~mm}$ long; lobes absent; corona $0.5 \mathrm{~mm}$ long with crystalline spines c. $0.2 \mathrm{~mm}$ long on the upper margin. Callus $0.7 \mathrm{~mm}$ long, curved, densely sericeous with white hairs minute-1 mm long. Awn 35-40 mm long, twice bent, c. $0.2 \mathrm{~mm}$ wide near the base; column c. $15 \mathrm{~mm}$ long, 7-8.5 mm to the first bend, straw-coloured, minutely scabrous; bristle strawcoloured, scabrous with hairs minute $-0.1 \mathrm{~mm}$ long. Palea $30-40 \%$ the length of the lemma, acute, hyaline, smooth and membranous, glabrous. Lodicules 2, abaxial, membranous, brown or hyaline, c. $1 \mathrm{~mm}$ long, oblong. Anthers 2-3 mm long, penicillate. Mature caryopsis not observed.

DistriBUtion: An introduction from S. America, uncommon on North Western Slopes of New South Wales.

Specimens Examined: New South Wales: North Western Slopes: Glen Innes to Inverell, Plante NSW 117383, 3.2.1951 (NSW); Gunnedah, cultivated, Barr NSW 117385, 1955 (NSW). Central Coast: Botanic Gardens, Sydney, cultivated, Steenbohm NSW 117386, 17.11.1974 (NSW).

Stipa juncifolia Hughes, Kew Bull. 1921: 11 (1921); Gardner, Fl. W. Austral. 1, Gram.: 174, 175, pl. 51 (1952), at least in part (Type cited).

Holotype: Western Australia: Swan River, Drummond, 4th coll. no. 377 (K!, CANB photo no. 236993). It is recorded by Rica Erickson in 'The Drummonds of Hawthornden' (1969) that Drummond's 4th Collection consists of specimens from King Georges Sound, Stirling Range, Porongorups, Mt Manypeaks, Cape Riche and West Mt Barren, and from N. and E. of Moore River. Most of these localities are more likely than the cited Swan River. 
Caespitose perennial to c. 1 metre high, shortly rhizomatous, without a basal tuft of leaves. Culms erect, $1-1.5 \mathrm{~mm}$ wide, \pm compressible, ribbed about the nodes, glabrous; nodes c. 3, exserted, glabrous. Leaf sheaths not inflated, slightly to moderately ribbed; basal sheath $7-9 \mathrm{~mm}$ wide, shortly puberulous with hairs $<0.5 \mathrm{~mm}$ long between the ribs; upper sheath $3-6 \mathrm{~mm}$ wide, glabrous to minutely puberulous between the ribs; margins glabrous. Ligule membranous, obtuse, $2.5-8 \mathrm{~mm}$ long, shortly puberulous with hairs $<0.05 \mathrm{~mm}$ long. Leaf blade tightly rolled, 1-2 $\mathrm{mm}$ in diameter, $2-4.5 \mathrm{~mm}$ in circumference, to $50 \mathrm{~cm}$ long; abaxial surface smooth and glabrous; adaxial surface densely scaberulous with minute siliceous prickles; margins scabrous with hairs $0.1 \mathrm{~mm}$ long or glabrous. Panicle $30-35 \mathrm{~cm}$ long, exserted, with distant fascicles of unequal, few-flowered compound branches, spreading, $3.5-8 \mathrm{~cm}$ wide (excluding awns); axis terete, glabrous; branches 1-13 cm long, slightly flattened, with sparse hairs $<0.05 \mathrm{~mm}$ long; pedicels $0.5-2 \mathrm{~mm}$ long, terete, glabrous. Spikelets $10-12 \mathrm{~mm}$ long (excluding awn), gaping at maturity. Glumes subequal, acute to acuminate, green at the base, purple-tinged across the centre, straw-coloured at the tip; lower glume 10-12 mm long, lower $60(-75) \% 3$-nerved; upper glume 9-10 mm long, lower (30-) 40\% 3-nerved. Floret cylindrical, without a neck, 6.5-9 mm long (including callus). Lemma smooth, sericeous with white hairs 0.5 (-0.8) $\mathrm{mm}$ long; lobes $2-2.5 \mathrm{~mm}$ long; coma 2-2.5 mm long. Callus $1.1-1.5 \mathrm{~mm}$ long, weakly bent at the tip; sericeous with white hairs $0.1-1 \mathrm{~mm}$ long. Awn 25-50 mm long, twice bent, $0.2-0.25 \mathrm{~mm}$ wide near the base; column $10-20 \mathrm{~mm}$ long, 5-10 $\mathrm{mm}$ to the first bend, scabrous with hairs $0.1-0.2(-0.5) \mathrm{mm}$ long; bristle darker than the column, scabrous with hairs $0.1-0.15 \mathrm{~mm}$ long. Palea equal to the lemma, $3(-4)$-toothed, slightly depressed between the nerves, surface smooth, sericeous along the centre back with hairs $0.5-1.5 \mathrm{~mm}$ long, margins glabrous. Lodicules 2, abaxial, membranous, obtuse, $0.5-1.5 \mathrm{~mm}$ long. Anthers $5(-6) \mathrm{mm}$ long, penicillate. Caryopsis not seen.

Distribution: Margins of salt lakes or saline depressions in the southern areas of Western Australia.

Specimens Examined: Western Australia: Avon: c. $20 \mathrm{~km} \mathrm{~N}$. of Cranbrook, Kuchel 1998, 20.9.1964 (AD). Roe: Jerramangup, Gardner, 9.1939 (PERTH); Lake King, George 10466, 11.11.1970 (PERTH, NSW); 5 km S. of Peak Eleanora, Newbey 6341, 8.11.1979 (PERTH). Eyre: Ravensthorpe, Gardner, 11.1944 (PERTH); 5 km NW. of Ongerup, Newbey 3587, 24.9.1972 (PERTH); nr. Toompup, Gardner, 10.1944 (PERTH); Fitzgerald River Reserve, Royce 9282, 24.10.1970 (PERTH); Martin Ck nr. Fitzgerald River, George 10939, 7.9.1971 (PERTH); Lake Quarderwardup, Beard 7571, 27.9.1975 (NSW); Stirling Range, Mueller, 10.1867 (MEL 60662); South Stirling, George 6494, 11.12.1964 (PERTH); E. of Albany-Borden rd., Aplin 2142, 19.10.1962 (PERTH); Kalgan, Mueller, s.d. (MEL 60663).

The specimen from Lake King (George 10466) differs from the other specimens in being considerably more robust with broader sheaths, longer leaves, a more compact inflorescence and basically larger spikelet dimensions and an awn to $7 \mathrm{~cm}$ long. This population warrants further field studies to assess the significance of the variation.

Bentham labelled and cited (Fl. Austral. 7: 566 (1878)) the Holotype of S. juncifolia as S. flavescens Labill., and Hughes therefore cited S. flavescens Benth. non Labill. as a 'synonym' of $S$. juncifolia.

In his treatment of Dichelachne setacea ( $\mathrm{R}$. Br.) Nees in Lehmann, Pl. Preiss. 2: 98 (1846), Nees cited Stipa setacea $\mathrm{R}$. Br. as the basionym; he also cited a specimen, Preiss 1854, from the interior of Western Australia. Veldkamp, Blumea 22: 11 (1974), regards a specimen of Preiss 1854 at BM as the Holotype of Dichelachne setacea Nees and identifies it as Stipa stipoides (Hook. f.) Veldk. 
We have not been able to find a specimen of Preiss 1854 at BM (as cited by Veldkamp), but specimens of this collection at MEL and LD are certainly not $S$. stipoides, differing in the shorter glumes and lemma, loose inflorescence and habitat as cited, but are quite consistent with $S$. juncifolia Hughes. Preiss 1854 is also the basis of Gardner's record (Fl. W. Austral. 1, Gram.: 174 (1952)) for S. stipoides from Western Australia. We have seen no material of true $S$. stipoides from Western Australia.

Stipa lanata J. Vickery, S.W.L. Jacobs \& J. Everett, sp. nov.

S. eremophilae affinis sed lemmate glabro marginibus non incidentibus, orificio et vaginis infernis longe lanatis, foliis plerumque latioribus, statura plerumque breviore, differt.

Holotype: Western Australia: 7 miles [11 km] N. of "Mundrabilla" Homestead. Found growing on gently undulating calcareous plain up to a height of $45 \mathrm{~cm}$ in a herbfield. Mitchell 2,31 July 1974 (PERTH).

Short caespitose perennial to c. 0.45 metres high. Culms $1-2 \mathrm{~mm}$ wide near the base, terete, ribbed, glabrous except pubescent for several $\mathrm{mm}$ below the nodes; nodes 1-2, glabrous to puberulous, exserted only in older geniculate culms. Leaf sheaths broad, the upper sheaths inflated, the innovations held tightly into bundles; ribs of lowermost sheaths long-woolly to hirsute, pubescent between the ribs, to glabrous with age on uppermost sheaths; outer margin glabrous to long-woolly ciliate, especially just below the ligule; inner margin glabrous. Ligule $0.4-1.5 \mathrm{~mm}$ long, truncate, densely ciliate; auricles with long woolly hairs. Leaf blades to c. $20 \mathrm{~cm}$ long and $1.5-4 \mathrm{~mm}$ wide, expanded to loosely rolled; abaxial surface densely long-woolly to very shortly pubescent or glabrous, especially on the older blades; adaxial surface densely long- to shortpubescent on upper leaves. Panicle $10-15 \mathrm{~cm}$ long, contracted, generally fewflowered, the base enclosed by the sheath except when fully mature; axis terete, pubescent, ribbed; branches terete, $10-40 \mathrm{~mm}$ long, hirsute to pubescent; pedicels angular, 4-15 mm long, hirsute to pubescent. Spikelet 19-26 mm long (excluding awn), not gaping at maturity, only slightly gaping after floret disarticulation. Glumes unequal, smooth, firm and often purple-coloured at the base, hyaline at the acuminate tips; lower glume 19-26 mm long, the lower $75 \%$ 3-nerved; upper glume 14-19 mm long, the lower 50\% 5-nerved, the next $25 \%$ 3-nerved. Floret turbinate, $6.5-8 \mathrm{~mm}$ long (including callus). Lemma entire, dark brown at maturity, smooth except for a very few antrorsely hooked tubercles at the neck, glabrous, with a sparse coma of dark rusty hairs $1.5 \mathrm{~mm}$ long, in two tufts; lemma margins not fully covering the back of the palea. Callus prominent, c. $3 \mathrm{~mm}$ long, sericeous with hairs white to dark rusty at maturity. Awn $0.4-0.5 \mathrm{~mm}$ wide near the base, $65-80 \mathrm{~mm}$ long, twice bent; column $22-30 \mathrm{~mm}$ long, $10-15 \mathrm{~mm}$ to the first and stronger bend, densely pubescent with hairs to $0.3 \mathrm{~mm}$ long; bristle scaberulous. Palea obtuse, equal in length to the lemma, ciliate at the tip, otherwise glabrous, the central strip c. $0.6 \mathrm{~mm}$ wide exposed for most of its length. Lodicules $2-3 ; 2$ abaxial oblong, membranous, c. $1 \mathrm{~mm}$ long; the paleal absent or acute, membranous, $0.5-0.8 \mathrm{~mm}$ long. Anthers not observed. Caryopsis $4 \mathrm{~mm}$ long; embryo c. $30 \%$ the length; hilum c. $85 \%$ the length.

DiSTRIBUTION: Arid regions of southern Western Australia and central and western South Australia. 
SPECimens Examined: Western Australia: Eucla: 7 miles $[11 \mathrm{~km}] \mathrm{N}$. of 'Mundrabilla' Homestead, Mitchell 2, 31.7.1974 (PERTH); Forrest, Trans Australia Railway Line, Johnston, s.d. (PERTH).

SOUTH Australia: Gairdner-Torrens Basin: 60 miles [100 km] ESE. of Kingoonya, Beauglehole 20041, 1.10.1966 (NSW). Eastern: Aldermans Park, 'Koonamore', Hilton 234, 16.10.1952 (ADW 44191); 'Koonamore', Everett 163, 165 \& Jacobs, 28.11.1980 (NSW).

See $S$. nullanulla and $S$. vickeryana for comparisons with this species. It is like $S$. eremophila but differs in the glabrous lemma with reduced margins, the long woolly hairs of the orifice and lower sheaths, the usually much broader sheaths and in usually being a shorter plant. Several specimens of $S$. eremophila, listed below, approach $S$. lanata very closely in having lemmas much more sparsely hairy than typical $S$. eremophila, and in having orifices and sheaths hirsute (nevertheless, not softly woolly). These can be found among populations of typical $S$. eremophila, and not differing noticeably from the other plants in any other character. These variants are treated here as $S$. eremophila.

SPECIMENS OF $S$. eremophila SHOWING AFFINITIES WITH $S$. lanata: South Australia: Murray: Moorundie [Wild Life Reserve], Cooper, 10.1941 (AD); Swan Reach, Everett 159, 160 \& Jacobs, 27.11.1980 (NSW). Western Australia: Eucla: 12 miles [19 km] from Madura, towards Cocklebiddy, along Eyre Highway, Phillips, CBG 039214, 1.9.1968 (CBG).

*Stipa leucotricha Trin. \& Rupr., Mém. Acad. Imp. Sci. Saint-Pétersbourg, ser. 6, Sci., Math., Seconde Pt. Sci. Nat. 5: 54 (1842); Hitchcock, Contr. U.S. Natl. Herb. 24: 225 (1925).

HoLOTYPE: U.S.A.: Texas, (?) Hooker (LE) (not seen).

Caespitose perennial to c. 0.5 metres high, without rhizomes, with a basal tuft of leaves about half the height. Culms erect to slightly geniculate at the base, terete to slightly angled, $1.5-3 \mathrm{~mm}$ wide near the base, slightly to scarcely compressible, moderately to strongly ribbed; basal culms moderately to strongly ribbed, glabrous; upper culms slightly to moderately ribbed, glabrous to minutely scabrous; nodes c. 2 , \pm exserted, not swollen, glabrous to sericeous with hairs minute- $0.8 \mathrm{~mm}$ long. Leaf sheaths at first tightly enveloping the culm, later becoming free, glabrous to scabrous between the ribs with minute tubercles; basal sheath $0.5-1.5 \mathrm{~cm}$ wide, slightly to moderately ribbed, inner margin glabrous, outer margin glabrous to ciliate with hairs $0.2-0.5 \mathrm{~mm}$ long; upper sheath 3-4 mm wide, strongly ribbed, inner margin glabrous, outer margin glabrous. Ligule membranous, truncate, $0.4-0.7 \mathrm{~mm}$ long; abaxial surface glabrous to minutely scaberulous; auricles thickened and spreading, 1-2 mm long, ciliate at the base with hairs $0.3-1 \mathrm{~mm}$ long. Leaf blade expanded to inrolled, $2-5 \mathrm{~mm}$ wide, to $30 \mathrm{~cm}$ long; abaxial surface moderately to strongly ribbed, glabrous to sparsely pubescent with hairs $0.3-0.5 \mathrm{~mm}$ long; adaxial surface strongly ribbed, glabrous to sparsely pubescent with hairs $0.1-0.5 \mathrm{~mm}$ long, denser and longer on the innovations. Panicle c. $15 \mathrm{~cm}$ long, exserted, with distant fascicles of unequal few-flowered, compound branches, contracted, 1-3 cm wide (excluding awns); axis terete to slightly angular, glabrous to scabrous along the edges with hairs minute $-0.4 \mathrm{~mm}$ long; branches $3-7 \mathrm{~cm}$ long, angled, glabrous to scabrous with hairs $0.1-0.6 \mathrm{~mm}$ long; pedicels $4-9 \mathrm{~mm}$ long, angled, scaberulous to scabrous with stiff hairs $0.1-0.5 \mathrm{~mm}$ long. Spikelets 10-17 mm long, gaping. Glumes subequal to equal, acute to acuminate, hyaline, glabrous or scabrous along the nerves with stiff hairs minute- $-0.6 \mathrm{~mm}$ long; lower 
glume 10-17 mm long, lower 30-50\% 3-nerved; upper glume 10-16 mm long, lower (35-) 40\% (5-) 3-nerved, margins sometimes ciliate. Floret 6.5-9 mm long (including callus), cylindrical with a neck. Lemma coarsely granular upwards with minute tubercles, sericeous only along the midrib with hairs $0.5-1.5 \mathrm{~mm}$ long; lobes absent; corona $1.5-2.5 \mathrm{~mm}$ long with a firm basal part $0.5-1 \mathrm{~mm}$ long, ciliate with hairs $1-1.5 \mathrm{~mm}$ long. Callus $1.2-3.3 \mathrm{~mm}$ long, weakly bent at the tip, densely sericeous with white hairs $0.2-1.5 \mathrm{~mm}$ long. Awn $50-60 \mathrm{~mm}$ long, twice bent, $0.4-0.5 \mathrm{~mm}$ wide near the base; column $20-30 \mathrm{~mm}$ long, $10-20 \mathrm{~mm}$ to the first bend, straw-coloured, scaberulous with hairs minute- $-0.8 \mathrm{~mm}$ long; bristle delicate, straw-coloured, scabrous with hairs minute $-0.1 \mathrm{~mm}$ long. Palea $35-50 \%$ the length of the lemma, acute to obtuse and erose, membranous, smooth and glabrous. Lodicules 2, abaxial, membranous, oblong, c. $1.5 \mathrm{~mm}$ long. Mature anthers not observed. Caryopsis c. $4 \mathrm{~mm}$ long; embryo $35 \%$ the length, hilum $85 \%$ the length.

DisTRIBUTION: Native to southern N. America; naturalised in suburban Melbourne, Victoria.

SPECIMEnS EXAmined: Victoria: Region N: Northcote, Morris, 10.1934 (MEL 60727 \& MEL 60731); Fairfield, Willis, 13.11.1946 (MEL 60729); North Brighton, Willis, 14.11.1948 (MEL 60730).

Stipa macalpinei Reader, Victorian Naturalist 15: 143 (1899) (as 'McAlpinei'); Hughes, Kew Bull. 1922: 22 (1922); Black, Fl. S. Austral. 4: 671 (1929), edn 2: 93 (1943); Gardner, Fl. W. Austral. 1, Gram.: 176 (1952); Willis, Handb. Pl. Vic. 1: 183 (1962), edn 2: 183 (1970); Eichler, Suppl. to Black's Fl. S. Austral.: 50 (1965).

TYPIFICATION: The Holotype was cited as 'Hilly Mallee country and sandy heaths. Lowan, Dimboola Shire, 1892; F.M. Reader'. We have not found any specimen collected by Reader in 1892 in MEL, where Reader's specimens are now located, but there are a number of specimens (cited below) collected by him in 1898 , some of which are named $S$. macalpinei in his handwriting. These have been taken as the basis of typification of this distinctive species.

Victoria: Region C: Desert, Lowan, Dimboola Shire, F.M. Reader, 20.11.1898 (MEL 59952); Lowan, F.M. Reader, 20.11.1898 (MEL 60732); Little Desert, F.M. Reader, 5.11.1898 (MEL 60733); Little Desert, Lowan, F.M. Reader, 5.11.1898 (MEL 60734) and 18.11.1898 (MEL 60735).

SYNONYMS: S. compressa var. lachnocolea Benth., F1. Austral. 7: 567 (1878). S. lachnocolea (Benth.) Hughes, Kew Bull. 1921: 26 (1921). (In 1922 Hughes synonymised this with S. macalpinei Reader.) Holotype: Western Australia: 'Drummond, n. 132' (K!).

S. setacea var. latifolia Benth., F1. Austral. 7: 568 (1878), as 'var. ?latifolia'; Hughes, Kew Bull. 1921: 30 (1921), under 'Species dubiae vel excludendae'. Hughes did not see any of the specimens quoted by Bentham. [S. scelerata Behr ex Benth., Fl. Austral. 7: 568 (1878), nomen nudum in syn.] TypifiCATION: Bentham cited 'Augusta, Behr; Crystal Brook, F. Mueller: Murray River, Blandowski. In MEL there are two specimens collected near Angaston, South Australia, by Behr in January (MEL 59988 in part). The locality is in writing that Bentham could easily have mis-read as Augusta. These specimens are certainly $S$. macalpinei Reader. We have not been able to find the other specimens either at MEL or $\mathrm{K}$ and so here designate MEL 59988 as Lectotype.

S. scelerata Behr ex Black, FI. S. Austral. 1: 65 (1922). TYPIFICATION: Black cites two elements: the synonym ' $S$. setacea $\mathrm{R}$. Br. var. latifolia Benth.' and a specimen from the 'Flinders Range, Sept. Dec. $\therefore$ Since he attributes the name to Behr, whose specimen was one of the elements of Bentham's variety, it appears that $S$. setacea var. latifolia Benth. should be taken as the replaced Synonym. At $\mathrm{K}$ (see CANB photo no. 237013) there is a specimen annotated in Black's handwriting 'Stipa scelerata, Pichi Richi Pass, Flinders Range, S.A., 20.9.20, J.M.B.' which presumably represents the second element in Black's protologue. This specimen represents a species entirely different from $S$. macalpinei, with much shorter and strongly falcate awns. It has been identified as $S$. arachnopus Pilg. by some later botanist, but it is not the Type of that name. Black's description certainly does 
not agree with $S$. macalpinei. Hj. Eichler (1965, see above) regards $S$. setacea var. latifolia Benth. and $S$. scelerata Behr ex Black as synonyms of $S$. macalpinei Reader. It is uncertain to what species of Stipa Ewart, Fl. Vict.: 182 (1931), applied the name S. scelerata Behr, but his description certainly does not apply to $S$. macalpinei.

Caespitose annual (to short-lived perennial?) to $90 \mathrm{~cm}$ high, without rhizomes, with a basal tuft to a tenth the height when present. Culms erect, terete, \pm compressible, c. 1-2 mm wide near the base, slightly ribbed, glabrous and smooth or scaberulous becoming glabrous upwards; nodes $1-4$, glabrous, rarely exserted, to $25 \%$ wider than adjacent internodes. Leaf sheaths to $13 \mathrm{~mm}$ wide, slightly ribbed; basal sheaths not inflated, densely minutely pubescent, also densely covered with characteristic flattened, transparent, blunt and flexuose hairs $0.8-1.2 \mathrm{~mm}$ long; upper sheaths inflated, either scabrous to scaberulous with minute antrorse to retrorse hairs or the same as the basal sheaths; inner margin glabrous; outer margin of almost all sheaths ciliate with hairs similar to the long flattened hairs of the lower sheaths. Ligule membranous, truncate, obtuse to laciniate on upper leaves, 1-15 mm long, longest on upper leaves, continuous on the upper sheaths with acute auricle lobes; abaxial surface minutely scaberulous; auricles thickened, $0.4-1.2 \mathrm{~mm}$ long. Leaf blades triangular to acuminate, expanded and as broad at the base as the sheaths, the remainder expanded to tightly inrolled, 5-15 $(-20) \mathrm{cm}$ long; abaxial surface slightly ribbed, glabrous and smooth to scabrous with minute antrorse to retrorse hairs; adaxial surface strongly ribbed, pubescent with hairs minute-2 mm long, longer on the innovations; margins similar to leaf surface. Panicle contracted or at length narrowly spreading, densely to sparsely flowered, with distant fascicles of unequal compound or simple branches, $10-35 \mathrm{~cm}$ long (excluding awns), 1-5 cm wide, exserted at last; axis scabrous to scaberulous with very short strong hairs \pm angled; branches to $15 \mathrm{~cm}$ long, scabrous to scaberulous, \pm angled. Spikelets $13-21 \mathrm{~mm}$ long (excluding awn), gaping. Glumes green to chaffy at the base, hyaline at the tip, very unequal; lower glume acuminate, 13-22 mm long, lower 45-66\% 3-nerved, minutely scabrous; upper glume broadly acute, 8-14 mm long, lower 25-60\% 5(-6)-nerved, upper $40-70 \%$ 4-1-nerved, glabrous but minutely scabrous at the tip, apex broadly acute, denticulate or rarely acuminate. Floret $7-8 \mathrm{~mm}$ long. Lemma with 1 or 2 lobes $0.1-0.4 \mathrm{~mm}$ long, white to pale yellow at maturity, at least the central nerve visible, pubescent with short and stiff hairs $0.2-0.4 \mathrm{~mm}$ long, hairs white to grey at maturity; coma absent. Callus straight, $1.5-3.5 \mathrm{~mm}$ long, densely covered with hairs similar to those on the lemma, 0.2-0.6 mm long. Awn 60-200 mm long, $0.2-0.35 \mathrm{~mm}$ wide near the base, slightly twice bent, scabrous with stiff hairs c. $0.05 \mathrm{~mm}$ long; column dark brown at maturity, $14-40 \mathrm{~mm}$ long, $10-30 \mathrm{~mm}$ to the first, more gradual but greater bend; bristle pale yellow, much paler than the column, delicate. Palea broadly acute, equal to or slightly longer than the lemma, similarly hairy with hairs $0.2-0.3 \mathrm{~mm}$ long, the tip inrolled, the surface smooth; margins glabrous. Lodicules 3 , membranous; 2 abaxial oblong, $0.8-1.5 \mathrm{~mm}$ long; paleal acute, minute-1 $\mathrm{mm}$ long. Anthers $1.5-2.5 \mathrm{~mm}$ long, not penicillate. Caryopsis $3-4 \mathrm{~mm}$ long; embryo $20-25 \%$ the length; hilum $90-95 \%$ the length.

Distribution: Drier parts of western Victoria, in heath or near coastal localities in southern South Australia and in the southern regions of Western Australia (but apparently not on the Nullarbor Plain).

Specimens EXAmined: Victoria: Region B: $12 \mathrm{~km}$ NW. of Broken Bucket Bushland Reserve, Beauglehole 57053, 19.11.1977 (MEL, NSW). Region C: Little Desert, Reader, 5.11.1898 (MEL 60733, 60734); Mt Arapiles, Beauglehole 29781, 23.11.1968 (NSW). Region D: Mt Sturgeon, Corrick 1246, 3.11.1968 (Corrick Herb.); Mt Abrupt, Grampians, Beauglehole 30205, 30.12.1968 (NSW). 
South Australia: Eyre Peninsula: Flora and Fauna Reserve, Hundred of Hincks, Specht 2572, 11.11.1960 (AD). Murray: Angaston, Behr, 1.1849 (MEL 59988, 59989). Southern Lofty: Hope Valley, Adelaide, Cleland NSW 116593, 9.1923 (NSW); Nangkita, Spooner 1719, 5.12.71 (AD); Mt Compass, Cleland, 26.10.1940 (ADW 43922, AD); Victor Harbor, Black 11.1926 (AD). Kangaroo Island: nr. Penneshaw, Hilton, 12.1946 (ADW 43919, NSW 116588, ADW 43920, 43921, 43924, 43925); between Salt Lake \& American R., Hilton, 7.11.1945 (ADW 5678); 'Hawks Nest', Cashmore, 22.11.1933 (ADW 263); Rocky R., Cleland, 18.11.1924 (ADW 43923, AD); mouth of South West R., Cleland, 7.12.1934 (AD); Govt. Experimentation plots, Symon, s.d. (ADW 44054). South-eastern: Dark Island Heath 9 miles (c. $15 \mathrm{~km}$ ) NE. of Keith, Specht \& Rayson 2, 12.1950 (AD); 'Pitlochry' station, Symon 8800, 30.11.1973 (ADW 43487, NSW 116592); between The Gap \& Western Flat, Hunt 214, 14.10.1961 (AD).

WESTERN Australia: Eyre: Scaddan, Burvil, 30.10 .1938 (PERTH); 17 miles [27 km] from Ravensthorpe, towards Lake King, Canning 7264, 6.11 .1968 (CANB, NSW); c. $2 \mathrm{~km} \mathrm{~N}$. of Moore R. bridge, Pullen 9731, 30.11.1974 (CANB, NSW); Esperance, Rose, 11.1961 (PERTH). Irwin: Kalbarri National Park, Crisp 6285, 6295, Taylor \& Jackson, 1.10.1979 (CBG); c. 4 miles [7 km] S. of Marchagee, Maslin 1437, 20.10.1970 (PERTH). Avon: nr. Mullewa, Adam, 9.1928 (PERTH); Watheroo National Park, Royce 9534, 4.10.1971 (PERTH); Merredin, Gardner, 10.1924 (PERTH); c. $18 \mathrm{~km}$ WNW. of Cunderdin, Haegi $1181,3.10 .1976$ (PERTH); Tutanning Reserve, $30 \mathrm{~km}$ E. of Pingely, Wilson 3913, 16.11.1965 (PERTH). Darling: 5 miles [8 km] SW. of Mogumber, Fisheries Inspector, 11.1964 (PERTH).

* Stipa megapotamia Sprengel ex Trin., Mém. Acad. Imp. Sci. St.Pétersbourg, ser. 6, Sci. Math. 1: 77 (1830); Hitchcock, Contr. U.S. Natl. Herb. 24: 275 (1925); Rosengurtt \& de Artucio, Bol. Soc. Argent. Bot. 9: 286 (1961); Rosengurtt, de Maffei \& de Artucio, Gramineas Uruguayas: 79 (1970).

HOLOTYPE: cited as 'brasil merid.', apparently collected from Uruguay (which was then included in Brasil), collected by Otto, no date (LE) (not seen).

Caespitose perennial to c. 1.3 metres high, with a basal tuft of leaves to a quarter the height, without rhizomes. Culms erect, terete, c. $1.5 \mathrm{~mm}$ wide near the base, not compressible, strongly ribbed to slightly ribbed upwards, glabrous; nodes 3, exserted, glabrous, slightly swollen. Leaf sheaths at first tightly enveloping the culm, later becoming slightly free, glabrous, innovations scabrous with hairs minute- $-0.2 \mathrm{~mm}$ long; basal sheaths $7-7.5 \mathrm{~mm}$ wide, smooth to slightly ribbed, inner margin glabrous, outer margin glabrous on innovations, elsewhere ciliate with hairs minute- $0.3 \mathrm{~mm}$ long; upper sheaths $5-8 \mathrm{~mm}$ wide, strongly ribbed, inner margin glabrous, outer margin ciliate with hairs minute- $-0.6 \mathrm{~mm}$ long, sometimes glabrous on innovations. Ligule truncate, membranous, to $0.7 \mathrm{~mm}$ long, glabrous; auricles \pm thickened, with a tuft of hairs $0.1-1 \mathrm{~mm}$ long at the base. Leaf blade expanded or loosely rolled, $3.5-4 \mathrm{~mm}$ wide, to $40 \mathrm{~cm}$ long; abaxial surface strongly ribbed to slightly ribbed upwards, glabrous; adaxial surface strongly ribbed, glabrous; margin ciliate with hairs $0.1-0.5 \mathrm{~mm}$ long, sparse on innovations. Panicle $25-35 \mathrm{~cm}$ long, exserted, with distant fascicles of unequal, few-flowered, compound branches, contracted, $2-3 \mathrm{~cm}$ wide (excluding awns); axis terete, with hairs $0.2 \mathrm{~mm}$ long; branches $7-14 \mathrm{~cm}$ long, slightly flattened with hairs $0.2-0.4 \mathrm{~mm}$ long; pedicels $0.2-0.8 \mathrm{~mm}$ long, slightly flattened, sericeous with hairs $0.1-0.3 \mathrm{~mm}$ long. Spikelets $8-10 \mathrm{~mm}$ long (excluding awn). Glumes subequal, acute to acuminate, straw-coloured, hyaline at the tip, scabrous along the nerves with hairs $0.1-0.2 \mathrm{~mm}$ long; lower glume 8-10 mm long, lower 40-60\% (4-) 3-nerved, upper 40-60\% (3-) 1-nerved; upper glume $9-9.5 \mathrm{~mm}$ long, lower $60 \%$ 3-nerved. Floret cylindrical, 5.5-6 mm long (including callus). Lemma surface scabrous with crystalline tubercles c. $0.05 \mathrm{~mm}$ long, sericeous along the ribs with white hairs $0.5-1.5 \mathrm{~mm}$ long along the nerves or glabrous; lobes $0.1-0.2 \mathrm{~mm}$ long; corona $0.5-0.8 \mathrm{~mm}$ long with spines $0.1 \mathrm{~mm}$ 
long on the upper margin. Callus $2-2.5 \mathrm{~mm}$ long, weakly bent at the tip, densely sericeous with hairs $0.2-1.5 \mathrm{~mm}$ long. Awn c. $50 \mathrm{~mm}$ long with $2-3$ bends, $0.3 \mathrm{~mm}$ wide near the base; column c. $30 \mathrm{~mm}$ long, $15-25 \mathrm{~mm}$ to the first bend, brown with hairs $0.1-0.5 \mathrm{~mm}$ long; bristle delicate, scabrous with hairs $0.1 \mathrm{~mm}$ long. Palea $20-25 \%$ the length of the lemma, membranous, non-vascular, acute, erose, glabrous and smooth. Lodicules 2, membranous, abaxial, c. $1 \mathrm{~mm}$ long, obtuse. Anthers not observed. Caryopsis $2.5-3 \mathrm{~mm}$ long; embryo $30-35 \%$ the length; hilum $65-80 \%$ the length.

Distribution: Native to S. America; apparently still confined to the Canberra region near its point of naturalisation.

Specimens Examined: New South Wales: Southern Tablelands: Black Mt, Canberra, Pullen 2592, 4.2.1961 (CANB, NSW), Pullen 3009, 4.1.1962 (NSW).

Apparently an escape from CSIRO plant introduction plots. The material naturalised in Australia matches material included in $S$. megapotamia var. megapotamia.

Stipa metatoris J. Everett \& S.W.L. Jacobs, Telopea 2(4): 399 (1983).

Holotype: New South Wales: Kyalite State Forest, $34^{\circ} 58^{\prime} \mathrm{S} 148^{\circ} 32^{\prime} \mathrm{E}$. Sandridge with Dodonaea and Callitris. J. Everett 341 \& S.W.L. Jacobs, 16.10.1981 (NSW).

Caespitose perennial to c. 1 metre high, with a basal tuft of leaves at least half the total height. Culms erect or geniculate, $1.5-2.5 \mathrm{~mm}$ wide near the base, terete, not compressible, scarcely ribbed, densely pubescent to puberulous or glabrous upwards; nodes $2-3$, densely sericeous, exserted, to $50 \%$ wider than adjacent internodes. Leaf sheaths tight around the culms, loose with age, 4-6 mm wide (the uppermost inflated and to $8 \mathrm{~mm}$ wide), densely pubescent to hirsute, or glabrous upwards; inner margin glabrous; outer margin densely ciliate with long hairs; cataphylls ciliate on both margins. Ligule thinly coriaceous, 1-2.2 mm long, broadly acute, obtuse to truncate, but always laciniate, densely ciliate; abaxial surface villous; auricles densely ciliate with long, fine, straight hair tufts. Leaf blades mostly tightly inrolled, 2-4 mm wide, to $40 \mathrm{~cm}$ long; abaxial surface scarcely ribbed, scaberulous and sparsely to densely pubescent, to almost glabrous; adaxial surface strongly ribbed, densely pubescent; margins scabrous with sturdy, minute antrorse hairs. Panicle spreading at maturity, 15-25 cm long, 3-6 cm wide (excluding awns), exserted but the base usually concealed; axis terete, pubescent to scaberulous. Spikelets $16-20 \mathrm{~cm}$ long (excluding awn), slightly gaping. Glumes unequal, glabrous or scaberulous on the nerves, the tips occasionally ciliate, firm and opaque, green or strawcoloured at the base, transparent at the tip, usually with a crescentic purple patch in the middle third; lower glume $16-20 \mathrm{~mm}$ long, long-acuminate, the lower 50-75\% 3-nerved; upper glume 12-15 mm long, acuminate, often broad in the middle, 5 -nerved in the lower $50 \%$, the next $20 \% 3$-nerved. Floret turbinate to cylindrical, $7-8 \mathrm{~mm}$ long (including callus). Lemma brown at maturity, the surface smooth, sericeous with long white to slightly fulvous hairs, sparse to absent just below the apex centrally; lobes 2, obtuse, $0.2-0.5 \mathrm{~mm}$ long; coma of hairs similar to those of the lemma, $2.5-3.5 \mathrm{~mm}$ long. Callus $2.0-2.8 \mathrm{~mm}$ long, straight, sericeous with hairs slightly darker than those of the lemma. Awn $0.3-0.35 \mathrm{~mm}$ wide near the base, $55-65 \mathrm{~mm}$ long, weakly twice bent; column 20-25 mm long, $11-13 \mathrm{~mm}$ to the first bend, pubescent with hairs $0.2-0.3 \mathrm{~mm}$ long; bristle scaberulous or pubescent with hairs $0.2-0.3 \mathrm{~mm}$ long. Palea obtuse, 
slightly shorter than the lemma, ciliate at the tip, sericeous with long hairs between the nerves, the margins glabrous. Lodicules 3 , membranous; 2 abaxial $1.5-2.0 \mathrm{~mm}$ long, oblong to slightly spathulate; paleal $0.5-1.0 \mathrm{~mm}$ long, acute. Anthers $1.2-4.0 \mathrm{~mm}$ long, penicillate. Caryopsis $3.5-4.5 \mathrm{~mm}$ long; embryo $30-40 \%$ the length; hilum $75-85 \%$ the length.

Distribution: Sandy areas of south-western New South Wales and south-eastern South Australia.

Selected Specimens: New South Wales: South Western Plains: Kyalite State Forest, Everett 341 \& Jacobs, 16.10 .1981 (NSW); c. 3 miles $[5 \mathrm{~km}]$ W. of Stony Crossing, Henderson 437 \& 438, 9.10.1947 (NSW); N. of Swan Hill, Henderson 440,5.11.1947 (NSW); c. $3 \mathrm{~km} \mathrm{NNW.} \mathrm{of}$ Cunninyeuk, Everett 78 \& Jacobs, 23.11.1980; Cunninyeuk, Henderson NSW 149127, 12.10.1946 (NSW).

South Australia: South-eastern: 3 miles [5 km] SE. of Bordertown, Specht 1584, 12.10.1947 (AD).

Stipa mollis R.Br., Prodr.: 174 (1810); Hughes, Kew Bull. 1921: 18 (1921); Vickery, Contrib. N.S.W. Natl. Herb. 2: 78 (1953); Beadle, Evans \& Carolin, Handb. Vasc. Pl. Sydney District: 531 (1963); Fl. Sydney Region: 656 (1972), edn 2: 660 (1982).

HolotYPE: 'Port Jackson, $R$. Brown, 1802-5' (BM!, isotype (no. 6205) K, CANB photo (of K sheet) no. 237016.)

SyNONYMS: S. semibarbata var. mollis (R. Br.) Benth., F1. Austral. 7: 569 (1878). Based on $S$. mollis $\mathrm{R}$. Br.

S. plagiopogon J. Black in Trans. \& Proc. Roy. Soc. S. Austral. 65: 334 (1941); F1. S. Austral. edn 2: 89 (1943). TYPIFICATION: Black cited four syntypes: 'Victor Harbor'; 'Inman Valley, 1926, J.B. Cleland'; 'Mt. Pleasant, 1933, E.C. Black'; 'Wilpena Pound, 1930, J.B. Cleland'. Specimens from Black's herbarium are mounted together on AD 97403342. The specimen mounted on the right hand side of the sheet, from Victor Harbor, Nov. 1926, consists of a complete culm with associated inflorescence in good condition, and we here designate this specimen as the Lectotype of $S$. plagiopogon J.M. Black (Dupl. MEL 59968). It is supported by a few detached florets, notes and sketches mounted on the lower left hand corner of the double mounting folder. The specimen 'Inman Valley, 1926, J.B. Cleland' has not been found; there are, however, a few detached glumes and lemmas, with notes and sketches, from 'Back Valley [which is near Inman Valley] 17.11.1930, J.B. Cleland'. The specimen from 'Mt Pleasant, 1933, E.C. Black' consists of a good inflorescence and culm but, as mounted, it is somewhat confused with an additional ticket bearing a few detached florets, sketches and notes, and annotated 'This specimen given Vict. Harb. July 1942' (sic!) (after the species was described). The specimen 'Wilpena Pound, 1930, J.B. Cleland' is represented on this sheet only by detached lemmas and notes. There is, however, another sheet, (AD 96323176) that bears a good specimen from 'Wilpena Pound, J.B. Cleland, 30.11.1930', but we are uncertain whether this was derived directly from Black's herbarium or subsequently from Cleland's herbarium. All the abovementioned specimens are Stipa mollis $\mathrm{R}$. Br.

Caespitose perennial to c. 1 metre high, not rhizomatous, with a basal tuft of leaves c. one-fifth the height. Culms erect, terete, $1.5-5 \mathrm{~mm}$ wide near the base, not compressible, very slightly ribbed to smooth; basal internodes pubescent with hairs minute- $-0.4 \mathrm{~mm}$ long near the nodes; upper internodes minutely scabrous to pubescent; nodes 3-5, exserted with age, densely sericeous with hairs minute $-0.3 \mathrm{~mm}$ long to glabrous, if swollen then $15-25 \%$ wider than adjacent internodes. Leaf sheaths at first tightly enveloping the culm, later becoming slightly loose, $5-10 \mathrm{~mm}$ wide; basal sheath very slightly ribbed, minutely pubescent to glabrous, inner margin glabrous, outer margin ciliate with hairs minute- $-0.4 \mathrm{~mm}$ long; upper sheath slightly to strongly ribbed, pubescent to tomentose, sometimes glabrous, inner margin glabrous, outer margin glabrous to ciliate with hairs $0.1-0.3 \mathrm{~mm}$ long; collar ciliate with hairs $0.6-0.7(-1.1) \mathrm{mm}$ 
long. Ligule truncate, membranous, $0.3-3 \mathrm{~mm}$ long, ciliate with hairs 0.3- $0.7 \mathrm{~mm}$ long; abaxial surface densely pubescent to hirsute; auricles absent. Leaf blade linear, tighly rolled, $1.5-3 \mathrm{~mm}$ wide, to $30 \mathrm{~cm}$ long; abaxial surface slightly to moderately ribbed, glabrous; adaxial surface strongly ribbed, tomentose with hairs minute- $0.3(-0.8) \mathrm{mm}$ long; margins glabrous to minutely scabrous. Panicle 10-30 cm long, exserted, with close fascicles of unequal manyto few-flowered, compound branches, contracted, $2.5-3.5 \mathrm{~cm}$ wide (excluding awns); axis terete, scabrous with stiff hairs minute- $0.15 \mathrm{~mm}$ long; branches $1.5-8 \mathrm{~cm}$ long, angled, scabrous with stiff hairs to $0.2 \mathrm{~mm}$ long; pedicels 1-10 $\mathrm{mm}$ long, angled, scabrous. Spikelets $16-20 \mathrm{~mm}$ long (excluding awn), gaping. Glumes equal to subequal, acuminate, hyaline, minutely scabrous, with occasional stiff hairs to $0.5 \mathrm{~mm}$ long on the nerves; lower glume $16-20 \mathrm{~mm}$ long with lower 55-75\% 3-nerved; upper glume 15-20 mm long with lower 20-40\% 6nerved, upper 80-60\% 4-1-nerved. Floret narrow-cylindrical, $7.5-9 \mathrm{~mm}$ long (including callus), without a neck. Lemma red-brown at maturity, the surface smooth to granular upwards, sericeous with hairs $0.4-0.8 \mathrm{~mm}$ long, lobes and coma absent. Callus $1.5-3 \mathrm{~mm}$ long, weakly bent at the tip, densely sericeous with white hairs $0.2-0.9 \mathrm{~mm}$ long, becoming yellow to fulvous at maturity. Awn 60-100 mm long, twice bent, $0.3-0.4 \mathrm{~mm}$ wide near the base; column 20-35 mm long, $10-17 \mathrm{~mm}$ to the first bend, brown, plumose with hairs $0.6-2 \mathrm{~mm}$ long, the hairs produced mostly along one side of the awn, appearing to spiral as the column twists; bristle dark brown to straw-coloured, scabrous with hairs $0.1 \mathrm{~mm}$ long and usually plumose at the base on one side with hairs similar to those of the column. Palea \pm equal to the lemma, acute, sericeous along the centre with hairs (0.1-) $0.4-0.6 \mathrm{~mm}$ long down the centre, surface slightly granular to smooth. Lodicules 2, abaxial, membranous, 1.5-2 mm long, acute. Anthers 1-4.5 mm long, penicillate. Caryopsis c. $4 \mathrm{~mm}$ long; embryo $20 \%$ the length; hilum $60-80 \%$ the length.

DiSTRIBUTION: Widespread on sandy and/or low nutrient soils of the southern States, including New South Wales.

Selected Specimens: New South Wales: Central Coast: Centennial Park, Sydney, Cheel NSW 115832, 15.10.1899 (NSW); Tempe district, Boorman NSW 115827, 10.1899 (NSW); Kogarah, Camfield NSW 115831, 10.1893 (NSW); Maroubra, Vickery NSW 115830, 17.10.1929 (NSW); Long Bay, Hilton NSW 116530, 22.11.1944 (ADW, NSW, AD); Sand hills near Sydney, Maiden, Kneucker, Gram. Exsicc. No. 196, 10.1900 (NSW); Sieber, Agrostotheca 60 [probably from the Port Jackson District] (MEL; ex Herb Lang). South Coast: Bowen Island, Rodway NSW 115823 , 17.12.1931 (NSW); Ulladulla, Pulley 329, 20.10.1969 (CBG); Bermagui, Vickery NSW 116487, 15.1.1940 (NSW); Green Cape, Phillips CBG 1270, 8.10.1961 (CBG). Central Tablelands: Towrang, Thomson NSW 115822, 15.11.1912 (NSW); Marulan to Berrima, Vickery NSW 116488, 11.1.1956 (NSW). Southern Tablelands: summit of Mt Budawang E. of Braidwood, Pullen 4126, 6.12.1965 (NSW, CANB, AD, MEL, BRI); Canberra, Moore M147, 19.12.1945 (CANB); Duntroon, A.C.T. Symon, 21.1.1952 (ADW 44144); Jerrabombera lookout near Queanbeyan, Gray 4663, 29.12.1959 (CANB). Central Western Slopes: Temora, Dwyer, 11.1916 (BRI, NSW).

VICTORIA: Region B: Pink Lakes, Williamson, 10.1928 (MEL 60761); Big Desert, 12 km NW. of Broken Bucket Bushland Reserve, Beauglehole 57054, 19.11.1977 (MEL). Region C: near Dimboola, Reader (MEL 60724); Horsham to Hamilton road, W. of the Grampians, Phillips NSW 116511, 31.10.1960 (NSW); Mt Arapiles, Beauglehole 29611, 19.11.1968 (NSW); between Booroopki \& Kaniva, Phillips CBG 054858, 2.11.1971 (CBG); John Smith Reserve, c, 12 miles [19 km] SW. of Horsham, Beauglehole NSW 116909, (NSW); N. side of Mt Zero, Grampians, Beauglehole 17823 \& Corrick, 5.11.1967 (NSW). Region D: Mt Sturgeon, Corrick 1614, 26.12.1968 (Corrick Herb); Billywing Swamp near Gleninsla, 40 miles [64 km] N. of Hamilton, Phillips CBG 001271, 31.10.1960 (CBG); Lower Glenelg Plantation near Renwick, Shepherd, 11.1950 (MEL 60760); W. of Mirranatwa Gap on Dunkeld to Halls Gap road, Symon 1724, 1.11.1961 (ADW); Grampians, Victoria Range, Kappa Cave area, Finck \& Beauglehole 4609, 2.3.1957 (NSW); Lake Mundi area W. of Casterton, Swindley 1128, 29.11.1962 (MEL); 7.5 miles [12 km] W. of Casterton, Beauglehole $37908,17.11 .1971$ (NSW); c. 14 miles [22 km] W. of Hamilton, Corrick 1545, 8.12.1968 (Corrick 
Herb). Region E: Mt Richmond National Park, Phillips CBG 003170, 26.10.1963 (CBG). Region F: c. $22 \mathrm{~km}$ SSW. of Robinvale, Beauglehole 56200, 5.5.1977 (MEL); Annuello, c. $23 \mathrm{~km} \mathrm{NNW.} \mathrm{of}$ Manangatang, Beauglehole 55889, 24.9.1977 (MEL). Region G: 5 km SW. of Chinkapook, c. 18 km S. of Manangatang, Beauglehole 55494, 17.4.1977 (MEL); Wathe Wildlife Reserve, $5 \mathrm{~km} \mathrm{W.} \mathrm{of}$ Gama, Beauglehole 56909, 22.10.1977 (MEL). Region H: Borung, mallee scrub, Reader, 25.10.1903 (MEL 60762); Lower Lodden, Walter NSW 116524 (NSW); Donolly, Phillips CBG 027106, 30.10.1963 (CBG); Wimmera, Wilson, 1870 (MEL 60763). Region J: 2 miles [3 km] SE. of Stawell, Muir 2647, 3.11.1962 (MEL); Grampians, Halls Gap, Symon 299, 13.11.1959 (ADW); Mt William, Grampians, Beauglehole 22229, 13.11 .1966 (NSW); Moyston, Sullivan, 12.1880 (MEL 60822); Wannon R., Williamson NSW 116493, 11.1899 (NSW). Region K: Port Campbell National Park, Finck \& Beauglehole 21465, 29.10.1966 (NSW). Region M: Epsom near Bendigo, Paton, 11.1921 (MEL 60833); Ravenswood, Bissill, (MEL 60823); 8 miles [13 km] ESE. of Melbourne, beyond Alamein railway station, Cullimore 92, 16.10.1967 (MEL, NSW). Region N: Puckapunyal, Davis NSW 116519, 10.11.1942 (NSW); Studley Park, Melbourne, Muir 519, 18.10.1958 (MEL, NSW, AD, CANB, BRI); near Dandenong Ranges, Dixon NSW 116499, 1891 (NSW, MEL, PERTH); Brighton, ex Herb. Hook. NSW 116510, (NSW); Sandringham, Meebold 21579, 11.1936 (NSW).

Region P: Frankston, Meebold NSW 116492, 1.1937 (NSW); Frankston to Langwarrin, Hart, 31.10.1931 (MEL 59996); Anglesea, Phillips NSW 116895, 28.10.1971 (CBG, NSW). Region S: Licola to Heyfield road, Beauglehole 43381, Willis \& Chesterfield, 21.10.1973 (ACB, NSW). Region T: Wilsons Promontory on road towards Five Mile Beach, Phillips CBG 027107, 23.11.1961 (CBG); Wilsons Promontory, Norman Point, Muir 614, 13.12.1958 (MEL). Region W: Bairnsdale, Vickery NSW 116900, 25.1.1935 (NSW); Sperm Whale Head, W. of Lakes National Park, Muir 2308, 13.10.1961 (MEL). Region Z: 2.5 miles [4 km] W. of Genoa, Beauglehole 32776, 24.12.1969 (NSW); 11.5 miles [18 km] SSW. of Mallacoota, Beauglehole 31068, 8.10.1969 (NSW); c. 5 miles [8 km] WNW. of Cape Everard, Beauglehole 32235 \& Finck, 10.12.1969 (NSW); 1 mile [1.6 km] NNW. of Cape Conran, Beauglehole 34515, 12.11.1970 (NSW).

TASmania: Waterhouse Estate, NE. Tasmania, Townrow 110, 18.12.1967 (JEST); 5.5 miles [9 km] S. of St Helens, Townrow 187, 19.1.1968 (JEST); Slopen I., Townrow 81, 82, 11.12.1967 (JEST); Dianas Basin, Simson, 11.1878 (MEL 60809); Launceston, Cleland NSW 116509, 11.1912 (NSW); Risdon, Blake I8323, 18.1.1949 (NSW, BRI); South Esk, Stuart 267 (MEL); 6 miles [9 km] N. of Ranger's house, Coles Bay, Townrow 180, 18.1 .1968 (JEST); Prosser River, 2.1 miles [3 km] W. of Orford, Townrow 71, 24.11.1967 (JEST); Runnymede, Townrow 63, 24.11.1967 (JEST); 2 miles [3 km] S. of Richmond on Cambridge road, Townrow 75, 25.11.1967 (JEST); between Dunalley \& Murdunna, Burbidge 3218, 20.1.1949 (CANB); Mt Wellington, Martin NSW 116503, 3.1933 (NSW); Opossum Bay, Townrow 49, 22.11.1967 (JEST).

South Australia: Flinders Ranges: Alligator Gorge, Hilton 44089, 5.8.1952 (ADW). Eyre Peninsula: Kimba district, French 28131, 9.1954 (ADW); Koppio turnoff on road from Tumby Bay, 11 miles [18 km] from Tumby Bay, Symon 917, 12.11.1960 (ADW); 4 miles [7 km] E. of Wanilla, Tindale 560a, 9.1970 (NSW); Port Lincoln, Crocker, 12.10.1944 (CANB); MacLaren Flat, Kraehenbuehl 1341, 1.11.1964 (AD). Northern Lofty: Mangalo area, Turner 28142, 12.1954 (ADW); Julia Range, 10 miles [16 km] S. of Burra, Symon 9355, 12.12.1953 (ADW); Mona Reserve, c. 5 km W. of Bute, Copley 834, 30.10.1966 (AD); Sevenhills, Copley 3264, 15.11.1970 (AD); Black Springs, Symon, 12.12.1953 (ADW 9354); Central Tothill Range, Kraehenbuehl 2195, 27.10.1963 (AD); S. of Freeling, Kraehenbuehl 1780, 6.11.1966 (AD). Murray: Monarto City Centre site, Symon 9733, 26.11.1974 (ADW); Kinchina, Cleland, 8.11.1924 (AD, NSW); Wynarka, Colquhoun 2492, 12.1936 (ADW); c. $5 \mathrm{~km} \mathrm{W.} \mathrm{of} \mathrm{Monarto} \mathrm{South,} \mathrm{Spooner} \mathrm{1639,} \mathrm{24.10.1971} \mathrm{(AD).} \mathrm{Yorke} \mathrm{Peninsula:} \mathrm{Happy}$ Valley, Cleland, 7.11.1926 (AD). Southern Lofty: $1 \mathrm{~km} \mathrm{~N}$. of Tanunda, Kraehenbuehl 1675, 23.10.1966 (AD); Mt Lofty Range, between Gawler \& Williamstown, Salasoo 1727, 1.1.1959 (NSW); Altona, via Lyndoch, Hilton 189, 27.10.1952 (ADW); Highbury, Smith 1801, 13.10.1969 Kraehenbuehl 712, 21.10.1962 (AD); Seaton Golf Links, Smith 649, The Pinery, Grange Golf Links, Reserve, Cleland, 14.11.1944 (AD); Camden [suburb of Adelaide], 13.1967 (AD); Nixon Skinner (AD); Barossa Reservoir, Cleland Camden [suburb of Adelaide], Kraehenbuehl 130, 3.11.1959 11.1938 (AD, NSW 116914); Stoneyfell Hills, Cleland Morialta, c. $10 \mathrm{~km}$ E. of Adel., Cleland, 31.10.1971 (AD); Longwood, Lazaroff 39, Cleland, 19.10.1952 (AD); Coxs Scrub, Crisp 115, 21.10.1970 (AD); Dernancourt, Smith 1792, 22.10.1969); Torrens Gorge West, Spooner 1119, 26.10.1967 (BRI); Mount Lofty Botanic Garens, 22.10.1969 (AD): W. of Crafers, Belcher 502, Adelaide, Hilton 43961, 17.11.1940 (ADW); Reserve, Symon 1922, 28.11.1961 (ADW); Belair, Koch 937, 11.1902 (K, NSW); Happy Valley Blackburn 28129, 20.10.1954 (ADW); Scrub, 4 km NE. of McLaren Flat, Bell 3cLaren Flat, Jackson 567, 30.10.1963 (AD); Douglas Gully [8 km] SE. of Willunga, Hilton, 11.11 .1941 , 11976 (BRI ex AD); Southern hills at Yundi, 5 miles NSW 116918, 9.1907 (NSW); Haven Garden, American River, Cleland (AD); between Kangaroo 
River and Kingscote, Hilton, 7.11.1945 (ADW 43966, NSW 116907); Stun'sail Boom River, Eichler 15434, 12.11.1958 (NSW). South-eastern: between Renmark \& Blanchetown, Griffiths NSW 116603, 18.9.1969 (CANB, NSW); Loveday, Gauba CBG 047571, 20.11.1943 (CBG); Back Valley, near Inman Valley, Cleland, 17.11.1930 (AD); Messent Wild Life Reserve, c. $170 \mathrm{~km}$ SE. of Adelaide, James 152, 14.11.1965 (AD); 10 miles [16 km] NE. of Keith on road to Sherwood, Hilton, 10.10.1953 (ADW 44079); Dark Island Heath, $15 \mathrm{~km} \mathrm{NE}$. of Keith, Specht I \& Rayson, 12.1950 (AD); Bordertown, Hunt 1619, 27.10.1963 (AD); between Western Flat \& Bordertown, Hunt 312, 28.10.1961 (AD); Bangham Scrub, 7-8 miles [11-13 km] S. of Western Flat, Symon 25881, 21.11.1962 (ADW); Lucindale, Carrodus, 8.1956 (AD); road to Naracoorte Caves, Phillips 356, 1.11.1971 (CBG); Stewarts Range district, Blackburn, 15.10.1954 (ADW 28128); Big Heath National Park, Hundred of Spence, Alcock 3066, 9.11.1969 (AD); 1.6 km NE. of Nangwarry, Wilson 614, 24.10.1966 (CANB, AD); 4 miles [6 km] N. of Millicent, Cleland, 12.1922 (AD); Princess Margaret Caves, Hilton, 31.1.1947 (ADW 44021).

Western Australia: Darling: between Augusta \& Nannup turnoff on highway, Phillips CBG 027108, 18.10.1962 (CBG); Tunney, S. of Kojonup, Royce 8052, 4.10.1963 (PERTH); near Lake Carabundup between Frankland \& Mt Barker, Pullen 9996, 12.12.1974 (CANB); Kalgan, Mueller, 10.1867 (MEL 60811); 36.5 miles [58 km] from Albany towards Borden via Chester Hill, Canning 6929, 28.10.1968 (BRI, AD). Avon: Wedgicarrup, W. of Wagin, Burbidge 2358, 10.9.1947 (CANB). Eyre: c. $32 \mathrm{~km}$ NNE. of the coast at Stokes Inlet, Orchard 1605, 18.10.1968 (PERTH); Cape Le Grand National Park, Royce 8777, 22.10.1969 (PERTH); Fitzgerald River near junction with Tivertup, George 10557, 19.12.1970 (PERTH).

$S$. mollis is quite similar to both $S$. semibarbata and S. hemipogon. From $S$. semibarbata it differs in the shorter floret $(9-11 \mathrm{~mm}$ in $S$. semibarbata) and the tendency for the hairs on the column to be longer and arranged in a more distinct spiral. From $S$. hemipogon it differs in the longer upper glume (10-16 $\mathrm{mm}$ in $S$. hemipogon), longer floret $(5-7.5 \mathrm{~mm}$ in $S$. hemipogon) and relatively shorter hairs on the longer column $(0.5-4 \mathrm{~mm} ; 10-20 \mathrm{~mm}$ in S. hemipogon).

Forms with hairs extending almost to the tip of the bristle could be confused with $S$. plumigera, but the presence of much longer hairs on the column, especially upwards, readily distinguishes $S$. mollis.

Stipa muelleri Tate, Trans. \& Proc. Roy. Soc. South Austr. 7: 70 (1885); Hughes, Kew Bull. 1921: 11 (1921), ibid. 1922: 16 (1922); Black, Fl. S. Austral. 1: 65 (1922), edn 2: 86 (1943); Willis, Handb. Pl. Vict. 1: 181 (1962), edn 2: 181 (1970).

Holotype: South AuSTRalia: 'Open parts in the stringy bark forests (Eucalyptus obliqua) at Uraidla, Mt Lofty Range, and scrublands c. Mt Jagged, towards Encounter Bay, flowering in October, R. Tate' (AD!).

Spreading perennial to c. 1 metre high without a basal tuft of leaves, shortly rhizomatous. Culms decumbent or at first erect, $0.7-0.9(-1.2) \mathrm{mm}$ wide near the base, wiry, compressible only when young, usually branching at the nodes, slightly ribbed, scabrous with hairs $0.2-0.25 \mathrm{~mm}$ long to glabrous upwards; nodes 3-7, exserted, not swollen, glabrous. Leaf sheaths tightly enveloping the culm, except where branching occurs; basal sheaths c. $4 \mathrm{~mm}$ wide, slightly to moderately ribbed, glabrous; upper sheaths $1-5 \mathrm{~mm}$ wide, very slightly ribbed, glabrous to tuberculate. Ligule a tuft of minute hairs; auricles absent. Leaf blade linear, thickened, $0.15 \mathrm{~mm}$ wide, to $1 \mathrm{~mm}$ long, readily deciduous; abaxial surface not ribbed, glabrous; adaxial surface not ribbed, scabrous with tubercles; margins glabrous. Panicle reduced to 1-3 spikelets, 2-3.5 cm long, exserted, without branches, open; axis terete, scabrous with stiff hairs $0.2 \mathrm{~mm}$ long; pedicels $0.6-1.5 \mathrm{~cm}$ long, terete to slightly flattened, scabrous with stiff hairs $1.5 \mathrm{~mm}$ long. Spikelets $1.8-3 \mathrm{~cm}$ long (excluding awn), gaping at maturity, 
otherwise tightly closed. Glumes subequal to equal, acute, straw-coloured or purple, glabrous on lower $80 \%$, upper $20 \%$ scabrous with stiff hairs 0.05-0.2 mm long; lower glume 18-30 mm long, lower 95\% 3-nerved, upper 5\% 2-nerved; upper glume 15-30 mm long, lower $70 \%$ 5-nerved, upper $30 \%$ 3-2nerved. Floret narrow-cylindrical, without a neck, c. $13-20 \mathrm{~mm}$ long (including callus). Lemma surface tuberculate, sericeous with hairs $0.3-0.6 \mathrm{~mm}$ long; lobes c. $3 \mathrm{~mm}$ long; coma absent. Callus c. $2-3 \mathrm{~mm}$ long, weakly bent at the tip, sericeous with white hairs $0.5-1 \mathrm{~mm}$ long. Awn $50-100 \mathrm{~mm}$ long, $0.5 \mathrm{~mm}$ wide near the base, twice bent, second bend stronger; column $40-55 \mathrm{~mm}$ long, $35-45 \mathrm{~mm}$ to the first bend, straw-coloured or dark brown, scabrous with hairs $0.02-0.2 \mathrm{~mm}$ long; bristle scabrous. Palea $75 \%$ the length of the lemma, acute to acuminate, surface smooth with a band of hairs $0.2-0.5 \mathrm{~mm}$ long down the centre back, margins glabrous. Lodicules $3 ; 2$ abaxial membranous, $2-5 \mathrm{~mm}$ long, acute or erose; paleal membranous, 3.5-5 mm long, erose. Anthers 8-13 mm long, penicillate. Mature caryopsis not observed.

DISTRIBUTION: Woodland and shrubland of southern Victoria and south-eastern South Australia.

SPECIMENS EXAMINED: VICTORIA: Region D: Grampians, Williamson NSW 116016, 11.1902 (ADW, NSW); 5 miles [8 km] W. of Mirranatwa Gap, Muir 2738, 6.11 .1962 (MEL); Mirranatwa Gap, Symon 146, 9.5.1959 (ADW); Victoria Range, Walter, 11.1899 (MEL 60742); Wannon R. above Dunkeld, Williamson, 10.11.1899 (MEL 60738). Region E: S. of Moleside, Beauglehole 715, 10.1946 (NSW). Region N: South of Belgrave, Corrick 3498, 20.10.1973 (NSW); Emerald, St. John, 11.1907 (MEL 59956). Region P: Arthurs Seat, Melville 2168, 30.11.1952 (NSW). Region S: Beenak, Willis, 22.12.1946 (MEL 60737); Gembrook, French, 11.1885 (MEL 60922).

South Australia: Southern Lofty: Mt Lofty, Crisp 1853, 24.12.1975 (CBG); Stirling West, Ising, 7.12.1959 (AD); Mosquito Flat nr. Mt Compass, Cleland, 26.10.1940 (AD); between Currency Creek \& Mt Compass, Cleland, 15.1.1940 (AD); S. of Second Valley Forest Reserve, Cleland, 12.12.1938 (AD); nr. Yankalilla, Eichler 14383, 15.11.1957 (AD). Kangaroo Island: Kangaroo Island, Tate, 1883 (MEL 60739). South-eastern: Riddock [Bay], Crocker, 9.11.1939 (ADW 4126).

Stipa multispiculis J. Black, Trans. \& Proc. Roy. Soc. S. Austral. 65: 333 (1941); Black, Fl. S. Austral. edn 2: 91 (1943).

TYPIFICATION: Black cited three Syntypes, all of which are extant in his herbarium now at AD. The first cited, 'Morialta, Oct. 1925, J.B. Cleland', represents a species different from the other two; it agrees with the species which Black knew as $S$. tenuiglumis (=S. flavescens). There is little doubt that Black drew upon the characters of this specimen, as well as the other two, in compiling his description, notably in arriving at the dimensions of the lemma and callus. However, Black's comments clearly indicate that he was distinguishing his new species from $S$. tenuiglumis and it would therefore be inappropriate to select the specimen from Morialta as the lectotype.

The second cited specimen, 'Port Noarlunga, Nov. 1926, J.B. Cleland' (AD 97421231), is a reasonably good specimen (though lacking the base) and seems to represent the species that Black was intending to describe. Black has clearly written 'Stipa multispiculus' on the sheet beside the specimen and initialled it. We here designate this specimen as the Lectotype of S. multispiculis J. Black. A good duplicate of it, derived from the Cleland herbarium, is also in AD.

The third cited specimen, 'Ardrossan (Yorke Peninsula) Nov. 1932, E.C. Black', consists of a single panicle without foliage or culm, but it certainly agrees with the specimen from Port Noarlunga.

Caespitose perennial to c. 1 metre high, with few conspicuously extravaginal shoots from a short rhizome. Culms geniculate or erect, not compressible, terete, (2-) 3-3.5 mm wide near the base, scarcely ribbed, scaberulous with dense, minute stiff hairs or puberulous to sericeous (especially just below the nodes) or occasionally \pm glabrous; nodes $3-5$, exserted, to $30 \%$ broader than adjacent internodes, densely sericeous. Leaf sheaths at first tightly enveloping the culms, soon becoming loose, slightly ribbed, scaberulous with dense, minute 
hairs, with or without scattered scabrous or soft hairs, or puberulous to almost glabrous; basal sheaths usually with more and longer hairs; inner margin glabrous; outer margin long-ciliate. Ligule firm and coriaceous, $0.2-0.7 \mathrm{~mm}$ long, truncate, usually dark-coloured, short- or long-ciliate; abaxial surface densely sericeous; auricles usually thickened and spreading with a tuft of hair at the base. Leaf blade expanded or only loosely rolled, to $8 \mathrm{~mm}$ wide and $60 \mathrm{~cm}$ long; abaxial surface ribbed, scaberulous with dense minute hairs or occasionally \pm glabrous; basal leaves usually more scabrous; adaxial surface ribbed, minutely scabrous or scaberulous to almost glabrous; margins glabrous. Panicle to $40 \mathrm{~cm}$ long, to $6 \mathrm{~cm}$ broad (excluding awns), exserted, loosely contracted, dense, with moderately distant fascicles of unequal many-flowered branches; axis terete to angular upwards, scabrous or scaberulous; branches to $12 \mathrm{~cm}$ long, terete to angular upwards, scabrous or scaberulous; pedicels $2-10 \mathrm{~mm}$ long, terete to angular upwards, scabrous or scaberulous. Spikelets $8.5-10 \mathrm{~mm}$ long (excluding awn), gaping. Glumes subequal, membranous, colourless, or green or purpletinged, appressed-pubescent to scaberulous overall or scaberulous only on the nerves; lower glume $8.5-10 \mathrm{~mm}$ long, long-acuminate, the lower $55-65 \% 3$ nerved; upper glume 6.5-9.0 mm long, acuminate, the lower $45-50 \%$ 5-nerved, the next $20 \% 3$-nerved. Floret narrow-cylindrical to narrow-fusiform, 4.5-6.0 mm long (including callus), with a weakly developed neck, the 3 main nerves slightly thickened at the apex. Lemma very finely granular, with sparse spreading white to yellowish hairs; coma $0.2-0.8 \mathrm{~mm}$ long; lobes $1-2$, c. $0.1 \mathrm{~mm}$ long. Callus $0.5-1.2 \mathrm{~mm}$ long, sturdy and curved, with hairs similar to those of the lemma. Awn 25-40 mm long, 0.2-0.3 mm wide near the base, gently twice bent; column 15-20 mm long, $7-12 \mathrm{~mm}$ to the first bend, scaberulous and densely pubescent with soft hairs $0.25-0.5 \mathrm{~mm}$ long; bristle scabrous. Palea broad-acute to obtuse, to $0.5 \mathrm{~mm}$ shorter than the lemma, coriaceous, smooth, with a band of sparse hairs down the centre; margins glabrous; tip ciliate. Lodicules 3, membranous; 2 abaxial c. $1 \mathrm{~mm}$ long, spathulate; paleal c. $1 \mathrm{~mm}$ long, triangular, broadly acute. Anthers $1.8-2.5 \mathrm{~mm}$ long, penicillate. Mature caryopsis not observed.

Distribution: Northern Lofty, Yorke Peninsula and Southern Lofty regions of South Australia.

Specimens EXamined: South Australia: Northern Lofty: South Hummocks Range, Copley 3235 , 25.10.1970 (AD). Yorke Peninsula: Innes National Park, Copley 4434, 28.8.1974 (AD). Southern Lofty: 3 miles (c. $4 \mathrm{~km}$ ) from Sandy Creek on the Williamstown road, Harris 36, 1.10.1959 (AD); Gawler cemetery, Spooner 3109, 13.10.1973 (AD); Torrens Gorge West, Spooner III5, 13.11.1970 (AD); Enfield, Smith 920, 12.10.1967 \& 1456, 24.10.1968 (AD); Morialta Conservation Park, Spooner 3208, 4.12.1973 (AD); Glen Osmond, Cleland, 9.10.1955 (AD); Waite Institute, Hilton, 20.9.1944 (ADW 43835, NSW); Greenhill Road, Cleland, 9.10.1948 (AD); Waterfall Gully, Adelaide Hills, Hilton, 14.10.1944 (ADW 44010); Blackwood, Ewers s.n., 14.10.1956 (AD 97737564); Port Noarlunga, Smith 449, 27.9.1967 (AD).

Similar to $S$. flavescens but differing in the shorter $(8.5-10 \mathrm{~mm}$ lower, 6.5-9 $\mathrm{mm}$ upper) glumes and shorter $(4.5-6 \mathrm{~mm})$ floret. Young plants of $S$. curticoma could be confused with $S$. multispiculis but differ in the longer $(6.5-8 \mathrm{~mm})$ floret and longer $(4.5-6.5 \mathrm{~cm})$ awn.

Stipa mundula J. Black, Trans \& Proc. Roy. Soc. S. Austral. 65 : 333 (1941); Black, Fl. S. Austral. edn 2: 91 (1941).

Holotype: South Australia: Chaunceys Line (N. of Lake Alexandrina), J.B. Cleland 12.10.1933 (AD 97423406; probable isotypes AD 96323226, 96323235, 97422298 in part; MEL 59957; ADW 44028, 44191). 
Densely caespitose perennial to $60 \mathrm{~cm}$ high with conspicuously extravaginal basal leaves usually c. one-third the height. Culms erect or geniculate, to $1 \mathrm{~mm}$ wide near the base, terete, compressible, scarcely ribbed, glabrous to puberulous, especially just below the nodes; nodes 2 , pubescent to almost glabrous, just exserted, to $30 \%$ broader than adjacent internodes. Leaf sheath tightly enclosing the culm, slightly ribbed, glabrous to minutely puberulous; inner margin glabrous; outer margin long-ciliate or, on the upper sheaths, glabrous. Ligule firmly membranous, truncate, $0.3-3.0 \mathrm{~mm}$ long, continuous with the sheath margin, ciliate or glabrous, abaxial surface glabrous; auricles often with a tuft of long straight hairs. Leaf blades tightly convolute-erect, $0.5-1 \mathrm{~mm}$ in diameter, to $15(-30) \mathrm{cm}$ long; abaxial surface unribbed, glabrous or with occasional strong or weak hairs; adaxial surface ribbed, scabrous with dense minute hairs and densely pubescent to hirsute; margins scabrous with short hooks. Panicle contracted or narrowly spreading, sparse, to $12 \mathrm{~cm}$ long, to $3 \mathrm{~cm}$ wide, exserted at length, with fascicles of few, unequal, few-flowered branches; axis \pm terete, scaberulous with very short hairs; branches terete to slightly angular, to $4 \mathrm{~cm}$ long, scaberulous with very short hairs; pedicels terete to slightly angular, to $10 \mathrm{~mm}$ long, scaberulous with very short hairs. Spikelets 12-17 mm long (excluding awn), gaping early in development. Glumes subequal to unequal, narrow, membranous, usually deeply purple-tinged at the base, hyaline at the tip, glabrous to minutely scaberulous on the nerves; lower glume $12-17 \mathrm{~mm}$ long, finely acuminate, the lower $60 \%$ obscurely 3 -nerved; upper glume 8-14 mm long, acuminate to broad-acute, the lower 30-60\% 5-nerved, the next $10-20 \% 3$-nerved. Floret narrow-turbinate to narrow-fusiform, the main nerve just visible, $6.5-8.0 \mathrm{~mm}$ long (including callus). Lemma red-brown at maturity, finely granular; hairs sparse, sparser at the apex, white becoming fulvous at maturity; coma obscure, 0.5-1.5 mm long; lobes 2, 0.1-0.5 mm long. Callus $2.2-3.0 \mathrm{~mm}$ long, fine and straight with hairs similar to those of the lemma. Awn $50-80 \mathrm{~mm}$ long, $0.25-0.35 \mathrm{~mm}$ wide near the base, gently twice bent; column $22-30 \mathrm{~mm}$ long, $10-16 \mathrm{~mm}$ to the first bend, pubescent with hairs $0.35-0.70 \mathrm{~mm}$ long; bristle scaberulous. Palea obtuse, c. $0.5 \mathrm{~mm}$ shorter than the lemma, very finely granular and with a band of dense long hairs down the centre, hyaline and glabrous at the margins, the tip ciliate. Lodicules 3, membranous; 2 abaxial, $1-1.5 \mathrm{~mm}$ long, oblong; paleal less than $0.2 \mathrm{~mm}$ long, acute. Anthers c. $3.5 \mathrm{~mm}$ long, not penicillate. Caryopsis 3-4 mm long; embryo $25 \%$ the length; hilum $80 \%$ the length.

DiSTRIBUTION: South-eastern South Australia, extending into Victoria.

Specimens Examined: Victoria: Region B: Big Desert, $35^{\circ} 17^{\prime} \mathrm{S}, 141^{\circ} 14^{\prime}$ E, Corrick 6394 , 2.10.1979 (NSW). Region C: Little Desert National Park, 36 31' S, $141^{\circ} 58^{\prime}$ E, Everett 203 \& Jacobs, 30.11.1980 (NSW); Sandy Desert, Reader, 27.10.1895 (MEL 60775); N. side of Mt Arapiles, Beauglehole 29857, 27.11.1968 (NSW). Region E: E. bank of Glenelg River, c. $1.6 \mathrm{~km}$ upstream from Donovans, Jackson 252, 18.11.1959 (AD).

South Australia: Eyre Peninsula: Warramboo, French 11, 10.1954 (ADW); Hincks National Park, Alcock 2178, 6.10.1968 (AD); Mt Wedge, Eichler 19388, 9.10.1967 (AD). Murray: Wanbi, Cleland, 12.10.1960 (AD 968061296). Yorke Peninsula: Hundred of Curramulka, Blaylock 252, 8.10.1966 (AD); Point Davenport, nr. 35 12'S., 137 24'E., Symon 11890, 4.11.1979 (ADW). Southeastern: $32 \mathrm{~km} \mathrm{E}$. of Tailem Bend, Everett 304, 23.9.1981 (NSW); Ki-Ki, 30 miles [48 km] SE. of Tailem Bend, Hilton NSW 116369 (NSW); 2 miles [3 km] W. of Coombe, Hilton, 11.10.1953 (ADW 44077); Big Heath National Park, Alcock 3029, 6.11.1969 (AD); Beachport \& Robe, Crocker, 3.1940 (ADW 4123); MacDonnell, c. 27 km S. of Mt Gambier, Cleland, 1.11.1941 (AD 96323318). 
* Stipa neesiana Trin. \& Rupr., Mém. Acad. Imp. Sci. Saint-Pétersbourg, ser. 6, Sci., Math., Seconde Pt. Sci. Nat. 5: 17 (1842); Hitchcock, Contrib. U.S. Natl. Herb. 24: 279 (1925); Caro, Kurtziana 3: 25 (1966); Rosengurtt, de Maffei \& de Artucio, Gramineas Uruguayas: 80 (1970).

HoLOTYPE: 'Monte Video, Sellow' (LE, not seen).

SYNONYM: S. eminens Nees, Agrost. Bras.: 374 (1829), non Cav. (1799). For further synonymy see Hitchock (loc. cit.).

Caespitose perennial to c. 0.75 metres high, with a basal tuft of leaves to half the height, without rhizomes. Culms erect or geniculate at the base, slightly angled, c. $1 \mathrm{~mm}$ wide near the base, \pm compressible, moderately to slightly ribbed, glabrous; nodes c. 2 , exserted, sericeous with hairs (minute-) $0.3-1.2 \mathrm{~mm}$ long, slightly swollen, to $25 \%$ wider than the adjacent internodes. Leaf sheaths at first tightly enveloping the culm later becoming slightly free, $0.5-1 \mathrm{~mm}$ wide, strongly ribbed; basal sheath glabrous or minutely scabrous, margins glabrous; upper sheath with scattered hairs $0.3-0.9 \mathrm{~mm}$ long to glabrous, outer margin ciliate with hairs $0.3-0.4 \mathrm{~mm}$ long to glabrous, inner margin glabrous. Ligule sometimes almost absent on lower leaves, otherwise truncate to obtuse, membranous, $0.5-3 \mathrm{~mm}$ long, with tufts of hairs at the sides, glabrous elsewhere; auricles thickened, $0.5-1.3 \mathrm{~mm}$ long, sparsely covered with hairs $0.1-0.3 \mathrm{~mm}$ long to glabrous. Leaf blade expanded to loosely inrolled, 2-2.5 mm wide, to $30 \mathrm{~cm}$ long; abaxial surface moderately to strongly ribbed, hirsute with hairs $0.1-1 \mathrm{~mm}$ long to glabrous; adaxial surface strongly ribbed, with hairs minute- $-0.7 \mathrm{~mm}$ long; margins scabrous with minute tubercles and occasional hairs $0.2-0.5 \mathrm{~mm}$ long. Panicle $10-40 \mathrm{~cm}$ long, exserted, with distant fascicles of unequal, few-flowered compound or simple branches, contracted, although narrowly spreading at anthesis, $1(-7) \mathrm{cm}$ wide (excluding awns); axis angled, strongly ribbed, scabrous along the edges with hairs minute- $0.4 \mathrm{~mm}$ long; branches $2.5-8.5 \mathrm{~cm}$ long, angled, scabrous along the edges with hairs $0.1-0.5 \mathrm{~mm}$ long; pedicels $1-8 \mathrm{~cm}$ long, angled, scabrous along the edges with hairs minute- $-0.6 \mathrm{~mm}$ long. Spikelets $14-18 \mathrm{~mm}$ long, gaping. Glumes equal to subequal, acuminate, hyaline; lower glume 14-18 mm long, lower 30-55\% 3nerved, scabrous along the nerves with hairs $0.1-0.5 \mathrm{~mm}$ long; upper glume $10-18 \mathrm{~mm}$ long, lower $20-50 \% \quad 5(-3)$-nerved, upper $50-80 \% \quad 3$-1-nerved, scabrous along the nerves with hairs $0.1-0.8 \mathrm{~mm}$ long. Floret $6-10 \mathrm{~mm}$ long (including callus), cylindrical with a neck. Lemma with one involute-margin coarsely scabrous with crystalline tubercles to c. $0.1 \mathrm{~mm}$ long, sericeous along the midrib of the lemma with white hairs $0.4-1.2 \mathrm{~mm}$ long; lobes absent; corona $1.5 \mathrm{~mm}$ long with spines c. $0.5 \mathrm{~mm}$ long on the upper margin. Callus 2.5-3.5 mm long, weakly bent at the tip, densely sericeous with white hairs 0.1-1.5 mm long. Awn 45-85 mm long, bent 2-3 times, $0.4 \mathrm{~mm}$ wide near the base; column $25-55 \mathrm{~mm}$ long, $15-30 \mathrm{~mm}$ to the first bend, straw coloured, scabrous to pubescent with hairs $0.1-0.5 \mathrm{~mm}$ long; bristle straw-coloured, scabrous with hairs c. $0.1 \mathrm{~mm}$ long. Palea membranous, non-vascular, similar to the lodicules, erose, oblong-acute, $20-25 \%$ the length of the lemma, glabrous and smooth. Lodicules 2, abaxial, membranous, 1-1.3 mm long, obtuse. Anthers 3-3.5 mm long, penicillate. Caryopsis 3-5 mm long; embryo $30-40 \%$ the length; hilum $80 \%$ to equal the length.

Distribution: Introduced from S. America and now spreading in the Central Coast, Northern Tablelands and Southern Tablelands subdivisions of New South Wales, also in Victoria.

Specimens Examined: New South Wales: Central Coast: Mt Druitt, Campbell NSW 117398, 7.11.1974 (NSW). Northern Tablelands: Tenterfield, 29 06 $\mathrm{S}, 152^{\circ} 00^{\circ}$ E, Johnson NSW 117399 , 
1.12.1976 (NSW); Glen Innes, Plante NSW 117402, 6.2.1948 (NSW). Southern Tablelands: Burbong, Pullen 2485, 20.12.1960 (CANB, NSW); Black Mountain, Gray 6443, 4.12.1969 (CANB, NSW, BRI); Commonwealth Gardens, Canberra, Gray 6441, 30.11.1969 (CANB, NSW); O'Connor, Canberra, Gray 6442, 2.12.1969 (CANB, NSW, BRI).

Victoria: Region J: "Bung Bong”, Yan Yean, Hewson, 16.1.1961 (MEL). Region K: Purnim, c. 9 miles [14 km] NE. of Warrnambool, Crook, 3.5.1967 (MEL 59964). Region N: Woodstock, Colchin, 1.1964 (MEL); Rosanna, Melbourne, Corrick 2914, 28.11.1973 (Corrick Herb).

All Australian specimens seem to belong to $S$. neesiana var. neesiana.

Stipa nitida Summerhayes \& Hubbard, Kew Bull. 1927: 60 (1927); Black, Fl. S. Austral. edn 2: 87 (1943).

Holotype: South Australia: Finnis Springs (S. of Lake Eyre), F.D. Warren, 25.8.1926 (K, 4 sheets!; CANB photo 237015; isotypes: AD 97422294, MEL 59959).

SYNONYM: S. scabra var. pallida Reader, Victorian Naturalist 17: 156 (1901). HolOTYPE: VICTORIA: Desert, Lowan, F.M. Reader, 11.1898 (MEL).

Possible SYNONYM: S. scabra var, auriculata J. Black, Fl. S. Austral. 1: 67 (1922). We have not yet found a specimen that can be definitely recognized as the Type, which was cited only as 'Dry districts'. One specimen labelled as $S$, scabra var. auriculata in Black's handwriting, from Laura, $8.10 .1916(\mathrm{~K} !)$ is a specimen of $S$. drummondii Steudel (see also note under that species).

Caespitose perennial c. 0.75 metres high, without rhizomes, with a basal tuft of mainly intravaginal shoots about half the height. Culms erect or slightly geniculate at the base, terete, $1-3 \mathrm{~mm}$ wide near the base, \pm compressible; basal culms smooth to slightly (-moderately) ribbed, glabrous or minutely puberulous to scaberulous with hairs minute- $0.2 \mathrm{~mm}$; upper culms smooth and glabrous; nodes 2-3, exserted at length, glabrous, to $50 \%$ wider than the adjacent internodes. Leaf sheaths at first tightly enveloping the culm, later becoming slightly loose; basal sheath $3-9 \mathrm{~mm}$ wide, slightly (to moderately) ribbed, glabrous to scaberulous to pubescent with hairs minute- $0.3 \mathrm{~mm}$ long, inner margin glabrous, outer margin glabrous to ciliate with hairs $(0.1-)$ $0.2-0.4 \mathrm{~mm}$ long; upper sheath $3-5 \mathrm{~mm}$ wide, moderately ribbed, (glabrous-) scaberulous to puberulous with minute tubercles or hairs minute- $-0.2 \mathrm{~mm}$ long, the innovations (glabrous-) scabrous to pubescent with minute tubercles or hairs, inner margin glabrous, outer margin glabrous or ciliate with hairs $(0.1-)$ $0.4-0.8 \mathrm{~mm}$ long. Ligule truncate, membranous, $0.3-1(-1.5) \mathrm{mm}$ long, ciliate with hairs minute- $-0.2(-0.6) \mathrm{mm}$ long; abaxial surface glabrous; auricle, when present, glabrous, c. $0.5 \mathrm{~mm}$ long, auricular lobes $0.5-3 \mathrm{~mm}$ long, ciliate with hairs $0.2-2 \mathrm{~mm}$ long, sometimes longer on the innovations. Leaf blade expanded to inrolled, 1-2 mm wide, to $40 \mathrm{~cm}$ long; abaxial surface slightly to moderately ribbed, (glabrous-) scaberulous to scabrous with hairs or tubercles minute- 0.1 $(-0.5) \mathrm{mm}$ long, the innovations sometimes hispid with hairs $0.1-0.5 \mathrm{~mm}$ long; margins glabrous to ciliate with hairs $0.1-0.2 \mathrm{~mm}$ long; collar glabrous. Panicle $25-55 \mathrm{~cm}$ long, \pm exserted, with distant fascicles of unequal, few-flowered, compound or simple branches, \pm contracted (although spreading at anthesis), $0.5-7 \mathrm{~cm}$ wide (excluding awns), axis smooth to moderately ribbed, terete to slightly angled, glabrous to minutely scabrous; branches $2-6 \mathrm{~cm}$ long, angled, scaberulous with hairs to $0.1 \mathrm{~mm}$ long; pedicels 2-10 mm long, almost flat, scaberulous with hairs to $0.1 \mathrm{~mm}$ long. Spikelets $8-13 \mathrm{~mm}$ long (excluding awn), gaping slightly. Glumes subequal, straw-coloured, acute to acuminate, $8-13 \mathrm{~mm}$ long, glabrous to scabrous along the midrib with hairs to $0.1 \mathrm{~mm}$ long; lower glume with the lower 20-30 (-40)\% 3-nerved; upper glume with the lower (15-) $30(-35) \%$ (3-) 5-nerved, upper (65-) $70(-85) \%$ 3-1-nerved. Floret narrow- 
cylindrical, without a neck, (4-) 5-6 mm long (including callus). Lemma smooth to slightly granular, sericeous with hairs $(0.2-) 0.3-0.5(-0.6) \mathrm{mm}$ long; lobes to $0.15 \mathrm{~mm}$ long, glabrous to ciliate with hairs to $0.1 \mathrm{~mm}$ long; coma obscure, of few hairs (0.2-) $0.3-0.8 \mathrm{~mm}$ long. Callus $1.2-2.2 \mathrm{~mm}$ long, weakly bent at the tip, densely sericeous with hairs to $1.5 \mathrm{~mm}$ long. Awn $45-70 \mathrm{~mm}$ long, falcate, $0.1-0.2 \mathrm{~mm}$ wide near the base; column $10-13 \mathrm{~mm}$ long, $6-9 \mathrm{~mm}$ to the first bend, straw-coloured to brown at maturity, scaberulous to pubescent with hairs mainly $0.1-0.3 \mathrm{~mm}$ long; bristle delicate, angled, straw-coloured to brown at maturity, scabrous with hairs to $0.2 \mathrm{~mm}$ long. Palea c. $90 \%$ the length of the lemma, obtuse to acute, often erose, smooth to slightly granular, sericeous down the centre back with hairs $0.2-0.4(-0.7) \mathrm{mm}$ long. Anthers usually penicillate, 1-3.5 mm long. Lodicules 2, abaxial, membranous, obtuse, $0.6-1.2 \mathrm{~mm}$ long. Caryopsis $2.5-3.5 \mathrm{~mm}$ long; embryo $25-40 \%$ the length; hilum $30-80 \%$ the length.

DiSTRIBUTION: Widespread on sandy soils of the drier winter rainfall areas in all mainland States.

Selected SPECimens: New South Wales: North Western Plains: Gundabooka, Henderson NSW $117249,16.1 .1948$ (NSW); c. $40 \mathrm{~km}$ from Louth, Tilpa road, Moore 4079, 20.9.1966 (CANB); 121 miles [194 km] W. of Cobar towards Wilcannia, Dunlop 1219, 27.8.1969 (CBG). South Western Plains: $21 \mathrm{~km}$ E. of Darnick, De Nardi 1094, 22.10.1972 (NSW); 12 miles [19 km] N. of Ivanhoe, Leigh NSW 117033, 30.9.1966 (NSW); Cunninyeuk, S. of Balranald, Henderson 181, 12.10.1946 (NSW). North Far Western Plains: Broken Hill, Johnson NSW 117029, 29.8.1946 (NSW); 11 miles [18 km] S. of Broken Hill on Silver City Highway, Jacobs 125, 11.11.1971 (NSW); 60 miles [96 km] E. of Broken Hill, Vickery NSW 117271, 20.8.1939 (NSW); 115 miles [184 km] E. of Broken Hill, Pidgeon \& Vickery NSW II7272, 20.8.1939 (NSW); 10 miles [16 km] E. of Silver City Highway on "Bindara" \& "Middlecamp" road, Jacobs 177, 12.11.1971 (NSW). South Far Western Plains: Menindee, Henderson 456, 18.9.1948 (NSW); Kinchega National Park, Ryan \& Everley NSW $117259,2.6 .1969$ (NSW); $26 \mathrm{~km} \mathrm{NW}$. of Gum Lake Railway Station, c. $28 \mathrm{~km}$ ESE. of Menindee. De Nardi 639, 22.9.1971 (NSW); Harcourt, Butler NSW 17261, 28.8 .1968 (NSW); 37 miles [59 km] from Pooncarie towards Darnick, Dunlop 1454, 31.6.1969 (CBG); $71 \mathrm{~km}$ from Pooncarie on road to Wentworth, De Nardi 1048, 18.10.1972 (NSW): Wilcannia road, Dareton, Butler NSW 117260 . 18.7.1969 (NSW); $12.8 \mathrm{~km} \mathrm{~W}$, of Balranald, De Nardi 1020, 16.10.1972 (NSW).

SouTH Australia: North-western: Ernabella Mission Station, Turvey NSW 117239, 20.7.1969 (NSW); 16 miles [26 km] SE. of Emu, Forde 439, 30.8.1956 (K ex CANB). Lake Eyre Basin: 'Allandale' Station, c. $20 \mathrm{~km}$ SE. of Oodnadatta, Kuchel 661, 5.8.1963 (BRI, dupl. of AD); 5 miles [8 km] N. of 'Mungeranie' Homestead, c. $190 \mathrm{~km}$ NNE. of Marree, Lothian \& Francis 325 , 24.8.1960 (BRI, dupl. of AD); 'Evelyn Downs', Ising, 16.9.1955 (ADW 19782, 19780, NSW 117022); 50 miles $[80 \mathrm{~km}] \mathrm{S}$. of Coober Pedy, Story 7837, 8.9.1956 (CANB): N. of Irapatana, Cleland NSW II7017, 7.8.1931 (NSW); Wangianna, $40 \mathrm{~km} \mathrm{W.} \mathrm{of} \mathrm{Marree,} \mathrm{Cleland,} \mathrm{4.9.1941} \mathrm{(AD);}$ 'Commonwealth Hill' Station, 55 miles [88 km] W. of homestead, Symon 337I, 19.2.1965 (ADW). Nullarbor: 15 miles [24 km] N. of Maralinga, Perry 5559, 26.1.1956 (CANB): 15 miles [24 km] E. of Immarna, Calaby, 18.10.1947 (CANB 15007); Cook-Ooldea, Hilton 1744, 23.8.1955 (ADW); Cook, Blake 18162, 10.9.1947 (BRI); Hughes, Hubbard 8369, 26.4.1931 (K, NSW); Talloran Tank near 'Nullarbor' Station, NNW. of Fowlers Bay, Cleland, 17.10.1953 (ADW 44067, 44058). GairdnerTorrens Basin: Wynbring, Ising 1216, 9.1920 (ADW, BRI, NSW); 'Purple Downs' Station, Andrewartha, 5.1938 (ADW 8291); 'Coondambo' Station, near Kingoonya, Reid, 28.8.1954 (ADW 28125, 28121): 'Wirraminna' Station, Reid, 28.8.1954 (ADW 28126); 10 miles [16 km] E. of Lake Hart, W. of Woomera, Beauglehole 22713, 24.6.1967 (NSW); 'Arkoona' Homestead, c. 18 miles [29 km] NE. of Woomera, Gauba CBG 047568, 22.6.1955 (CBG). Flinders Ranges: lower slopes of hills below Paralana Springs, Symon 6082, 24.8.1968 (ADW, NSW); Mt Lyndhurst, Koch 371. 8.1899 (K, NSW); $22 \mathrm{~km} \mathrm{NE}$. of Lyndhurst, Sikkes 1138 \& Ollerenshaw, 26.9.1973 (CBG); c. $3 \mathrm{~km}$ E. of Nepabunna Mission, Lothian 2579, 27.9.1963 (BRI, dupl. of AD); Parachilna, Cleland NSW 117032, 19.8.1921 (NSW). Eastern: Billeroo Creek area, c. $45 \mathrm{~km}$ ENE. of 'Frome Downs' Homestead, Whibley 3432, 25.7.1971 (AD, NSW); Koonamore [60 km N. of Yunta]. Carrick 1798, 6.10 .1968 (AD, NSW); $20 \mathrm{~km} \mathrm{~S}$. of Yunta, Carrick 2111, 7.10.1968 (AD, NSW): White Well, Cleland, 19.10.1954 (ADW 43886). Eyre Peninsula: 49 miles $[78 \mathrm{~km}]$ from Nundroo toward 'Nullarbor' Homestead, Canning CBG 039492, 3.9.1968 (CBG); 'Yudnapinna' Station, Crocker. 10.1939 (ADW 22959); Ceduna, Canning 2352, 3.9.1968 (NSW dupl. of CBG); near Yardea, 50 miles [80 km] NE. of Minnipa, Cleland, 12.10.1954 (ADW 43889); Minnipa-Wudinna, French 4, 10.1954 (ADW 43711, NSW); Whyalla, Hilton, 10.9.1952 (ADW 43905); towards Whyalla from Port 
Augusta, beyond Iron Knob turnoff, Phillips CBG 067216, 15.9.1973 (CBG); between Kimba \& Port Augusta, Reeve 364, 21.8.1972 (CANB); 2 miles $[3 \mathrm{~km}] \mathrm{N}$. of Cowell, Pearce, 2.1965 (ADW 44115), Murray: 'Bunyung' Station, Morgan, Reid, 1.4.1954 (ADW 44131); Florieton, N. of Mount Mary, Clarke, 26.10.1936 (ADW 19779); $22 \mathrm{~km}$ from Morgan towards Burra, Phillips CBG 059904, 2.9.1962 (CBG); Stoney Pinch Dam, 'Calperum' Station, NE. of Overland Corner, Symon 3845, 11.10.1965 (ADW); Loveday, Gauba CBG 006473, 14.12.1944 (CBG)

NORTHERN TERritory: 120 miles [192 km] S. of Alice Springs, Vasek, 17.9.1968 (CANB); Erldunda, c. 125 miles [200 km] S. of Alice Springs, Paige, 12.11.1968 (CANB, dupl. of NT); 8 miles [13 km] WNW. of Ayers Rock, Lazarides 6152, 7.9.1956 (CANB); between 'Mt Cavenagh' \& 'Victory Downs' Homesteads, Beauglehole 22771, 27.6.1967 (NSW).

Western Australia: Eucla: 74 miles [118 km] E. of Rawlinna, Goodall 2708, 19.8.1966 (PERTH); c. 100 miles [160 km] N. of Rawlinna, George 8475, 12.10 .1966 (PERTH); Eucla, Phillips CBG 042585, 1.9.1968 (CBG, BRI); 25 miles [40 km] W. of Cocklebiddy, Main, 29.11.1959 (PERTH). Austin: 11 miles [18 km] N. of Meekatharra, Speck 1082, 29.7.1958 (CANB, NSW); 6 miles [10 km] NW. of Mt Newman, Severne 360978 (PERTH); 'Barnong' Station, Humphries, 17.9.1951 (PERTH); Leonora road, $38 \mathrm{~km}$ WSW. of Laverton, Beauglehole 59801 \& Errey, 15.9.1978 (NSW); 18 miles [29 km] N. of Menzies, towards Leonora, Phillips CBG 0417459, 7.9.1968 (CBG, BRI); between Menzies \& Comet Vale, Blackall 4185, 13.9.1939 (PERTH). Carnarvon: Hamelin Pool, George 1484, 1.9.1960 (PERTH). Coolgardie: 3 miles [5 km] E. of Coolgardie, Phillips CBG 020680, 13.9.1962 (CBG); Kalgoorlie, Blake 18160, 9.9.1947 (BRI). Avon: Walgoolan, O'Leary, 3.4.1924 (K). Giles: Docker Mission Road, 171 km E. of Warburton Mission, Beauglehole 60253 \& Errey, 20.9.1978 (NSW).

$S$. nitida is a very variable species. The population represented by the Holotype has woolly-hairy auricles. The auricles from other populations vary from glabrous to woolly, with no detectable pattern that we could correlate with variation in other characters. There is similar variation in other vegetative characters; for example, the following specimens all have broad leaves and sheaths:

SouTH AUSTRALIA: Ooldea, Cleland NSW 15100, 25.8.1922 (NSW); Upper Arkaringa Vale, Helms, 29.6.1891 (NSW); Government NW. expedition, Basedow 118, 508, 1908 (NSW). WESTERN Australia: NW. Australia, Crawford 368, 1909 (NSW 151497, 151498, 151499); 5 miles [8 km] S. of Yelma, Speck 1342, 1.9.1958 (NSW); c. 42 km SW. of Meekatharra, Beauglehole 49060A, 22.8.1974 (NSW); $65 \mathrm{~km} \mathrm{NE}$. of Laverton, Beauglehole 59963 \& Errey, 16.9.1978 (NSW); $5 \mathrm{~km} \mathrm{~N}$. of Kalgoorlie, Hoble 6, 10.8.1973 (NSW); Gindalbrie, Noble 242, 10.8.1973 (NSW); Lawlers, ?Fitzgerald, 7.1899 (NSW); Fraser Range, Helms, 12.10.1891 (NSW).

Other such groups of specimens can be separated from $S$. nitida but we have been unable to detect any reliable pattern in the variability. Clearly this large species and its many forms would be worthy of further studies.

Hughes incorrectly determined specimens of $S$. nitida, 'without precise locality, Sinclair' (CANB 117325 received from BM) and 'Mt Lyndhurst, M. Koch no. 371, $8.1899^{\prime}$ (K) as S. scabra Lindl. The Koch specimen was the basis for her figures 18 and $18 \mathrm{~A}$. We have not seen all the other sheets she cites from South Australia and Western Australia but it seems possible that they also may be $S$. nitida.

S. nitida is host to a previously unrecorded 'Cockle' infection caused by an apparently undescribed Anguinid (tribe Anguinieae) nematode (Dr. J. Southey, pers. comm.). This infection causes the inflorescence to become dense and compact, 'Barley-like' is used on one herbarium label. The shape of the floret changes, losing the characteristics of the genus Stipa. The lemma is only gently curved and barely overlaps the palea margins. The awn remains more or less straight and does not twist. The pseudo-caryopsis has neither embryo nor hilum and on breaking it open the coiled desiccation-resistant larval stage of the nematode can be seen. The following specimens are examples of this infection: 
Victoria: Wyperfeld National Park, Beauglehole 28523, 19.9.1968 (NSW, IMI p.p.). SouTH Australia: 2 miles [3 km] E. of Maralinga, Bown 130, 9.1956 (K, IMI, ?AD); nr. Corunna Hill, Iron Knob, Copley 2317, 2.10.1968 (AD, IMI).

Further specimens may exist but the changed appearance of inflorescence and spikelet may have led to their being incorrectly identified.

Stipa nivicola J.H. Willis, Victorian Naturalist 73: 149 (1957); Handb. Pl. Victoria 1: 188 (1962), edn 2: 188, 435 (1970); Burbidge \& Gray, Fl. Austral. Cap. Terr.: 153 (1970).

Holotype: Victoria: Bogong High Plains, $1650 \mathrm{~m}$, grassy slopes of Middle Creek, near Rover Scout Hut, J.H. Willis, 2.2.1949 (MEL; isotype NSW 116164).

Caespitose perennial to c. 0.5 metres high, shortly rhizomatous with a basal tuft of leaves c. half the height. Culms erect, or decumbent, c. $1 \mathrm{~mm}$ wide near the base, scarcely compressible, slightly ribbed or smooth, very shortly pubescent just below the lower nodes, minutely sericeous just below the upper nodes, glabrous elsewhere. Nodes $2-3, \pm$ exserted, not swollen; lower nodes glabrous to rarely sericeous with hairs $0.05 \mathrm{~mm}$ long; upper nodes sericeous with hairs $0.05-0.15 \mathrm{~mm}$ long. Leaf sheaths at first tightly enveloping the culm, later becoming slightly loose; basal sheath $4-5 \mathrm{~mm}$ wide, moderately ribbed at the base, very slightly ribbed elsewhere, glabrous to minutely scabrous between the nerves, margins glabrous; upper sheath 3-4 mm wide, strongly ribbed, centre glabrous, edges minutely scaberulous, inner margin glabrous to ciliate with hairs c. $0.15-0.2 \mathrm{~mm}$ long, outer margin ciliate with hairs $0.1-0.3 \mathrm{~mm}$ long to glabrous. Ligule truncate, firm, $0.4-1.5 \mathrm{~mm}$ long, ciliate with hairs $0.05-0.5 \mathrm{~mm}$ long; auricles absent. Leaf blade linear, tightly rolled, $1.5-3.5 \mathrm{~mm}$ wide, to $20 \mathrm{~cm}$ long; abaxial surface smooth to very slightly ribbed, glabrous; adaxial surface strongly ribbed, densely scaberulous with minute siliceous prickles; margins scabrous with hairs to $0.05 \mathrm{~mm}$ long or glabrous upwards. Panicle 5-20 cm long, exserted, sparse with 8-12 spikelets, with distant fascicles of unequal few-flowered branches, contracted, $1-2.5 \mathrm{~cm}$ wide (excluding awns); axis terete or slightly flattened, slightly scabrous with minute tubercules or hairs $0.1-0.2 \mathrm{~mm}$ long; branches $3-4 \mathrm{~cm}$ long, angular, scabrous with hairs $0.2 \mathrm{~mm}$ long; pedicels $1-3 \mathrm{~cm}$ long, angular, scabrous along the edges with hairs $0.05-0.15 \mathrm{~mm}$ long. Spikelets $20-25 \mathrm{~mm}$ long (excluding awn), gaping. Glumes subequal, purple, with prominent straw-coloured nerves, minutely scabrous on the margins and across the tip with hairs less than $0.5 \mathrm{~mm}$ long to glabrous; lower glume acute to acuminate, 20-25 mm long, lower 60-80\% 4-nerved, upper $40-20 \%$ 2-1-nerved; upper glume acute, 15-20 mm long, lower $35-50 \% 5$ nerved, upper $65-50 \%$ 4-1-nerved. Floret narrow-cylindrical, $12-15 \mathrm{~mm}$ long (including callus), without a neck. Lemma surface scabrous with minute tubercles, sericeous with hairs $0.5-1 \mathrm{~mm}$ long; coma and lobes absent. Callus c. $3.5 \mathrm{~mm}$ long, weakly bent at the tip, densely sericeous with hairs to $0.8 \mathrm{~mm}$ long, white to orange at maturity. Awn $85-130 \mathrm{~mm}$ long, twice bent, c. $0.5 \mathrm{~mm}$ wide at the base; column 55-70 mm long, $45-60 \mathrm{~mm}$ to the first bend, strawcoloured, sparsely scabrous with hairs $0.05-0.5 \mathrm{~mm}$ long; bristle delicate, strawcoloured, scabrous with hairs $0.1-0.15 \mathrm{~mm}$ long. Palea equal to the lemma, acute, glabrous. Lodicules 2, abaxial, oblong, 1-1.7 mm long. Caryopsis 6-7.5 mm long; embryo $20 \%$ the length; hilum equal to the length.

Distribution: Southern New South Wales and northern Victoria on the Australian Alps and Bimberi Range. 
Selected Specimens: New South Wales: Southern Tablelands: Brindabella Range, $1.3 \mathrm{~km}$ ENE. of Mt Ginini, Crisp 2454, 28.1.1977 (CBG); Ginini Flats, Solling NSW 116183, 24.3.1972 (NSW); Snowy Flat, nr. Mt. Gingera, Bimberi Range, Pullen 3833, 27.2.1963 (CANB, NSW, BRI); Mt Gingera, Gray 6009, 10.2.1967 (CANB, BRI, MEL); plain N. of Kiandra, Gauba CBG 006095 , (CBG, AD); 2 miles [3 km] W. of Kiandra, Burbidge 3907, 22.2.1955 (CANB); Kiandra, Newman NSW 116155, 8.2.1954 (NSW); S. of Kiandra, Gauba CBG 003942, 16.1.1950 (CBG, MEL, BRI); ridge above Happy Jacks township, Vickery NSW 42740, 20.1.1958 (NSW); McKeahnies Creek catchment, Phillips CBG 008884, 28.1.1965 (CBG); 8 km SSE. of Mt Selwyn, Everett 465, 3.1.1984 (NSW); Upper Tumut Catchment, nr. Doubtful River, Newman NSW 116163, 26.3.1954 (NSW); Perisher Creek, Johnson NSW 18686, 23.1.1951 (NSW); Kydra Peaks, Willis NSW 116705, 11.1.1970 (NSW, dupl. of MEL 501959); Mt Kosciusko, Mueller NSW 116156, 25.3.1953 (NSW); Doubtful River, Mueller NSW 116160, 23.2.1953 (NSW); Monaro, Taylor NSW 116161, 13.2.1953 (NSW).

Victoria: Region R: Mt Buffalo, Willis, 18.2.1963 (MEL). Region S: Snowy Range, Airstrip Plain, Beauglehole 40974, 5.1.1973 (NSW); Snowy Range, Buyee Plain, Beauglehole 40872 \& Chesterfield, 31.12.1972 (NSW); Big Plain, NW. of Mt Wellington, Willis NSW 116702, 12.3.1966 (NSW, dupl. of MEL 503312). Region V: Buckety Plain, Bogong High Plains, Beauglehole NSW $116169,28.1 .1966$ (NSW). Region W: Brumby Point, Nunniong Plateau, Beauglehole 36537 \& Finck, 21.1.1971 (NSW).

Neither open florets nor exserted anthers have been observed amongst the material examined but anthers have been observed to be shedding pollen while totally enclosed by the lemma; it appears that the spikelets are normally cleistogamous.

Stipa nodosa S.T. Blake, Proc. Roy. Soc. Queensland 62: 89 (1952); Black, Fl. S. Austral., rev. Jessop, edn 3, 1: 108 (1978).

Holotype: South Australia: Flinders Ranges in Parachilna Gorge, between Blinman and Parachilna Spring, S.T. Blake 16914, 1.9.1946 (BRI 008016, 008017; isotype AD).

SynONYmS: S. effusa Hughes, Kew Bull. 1922: 20 (1922), non Mez (1921); Black, Trans. \& Proc. Roy. Soc. S. Austral. 63: 241 (1939). Holotype: New South Wales: Lachlan River, Mueller, Sept. 1878 (US 993696!; isotype $\mathrm{K}$, also CANB photo 237023). The specimen at Kew consists of a pencil habit-drawing of a portion of the plant in the U.S. National Herbarium, which was lent to Kew in 1921 , together with a packet containing a few spikelets and florets. The specimen at US is in good condition and bears the name 'Stipa effusa Hughes' in Hughes' own handwriting.

S. falcata var. minor J. Black in Trans. \& Roy. Soc. S. Austral. 65: 334 (1941); FI. S. Austral. edn 2: 87 (1943). LECTOTYPE, here designated: Wilpena Pound, J.B. Cleland s.n., 10.11.1928 (AD 97424083). Black cited 'Flinders Range' without specifying any particular location. In his herbarium at AD there are several presumed syntypes from the Flinders Ranges on which he has written the name. They are all specimens of $S$. nodosa Blake. Presumed syntypes include specimens mounted on the sheets AD 97424083, 97424085, 9742084, 97424087, 97424086, 97424082.

[MiSAPPLIED NAME: A specimen of $S$. nodosa from Ardlethan [New South Wales], R.H. Cambage NSW 117120, 1.10.1916 (NSW), formed the basis of the illustration over the caption 'Stipa scabra' in Breakwell, Grasses and Fodder Plants of N.S.W.: 226, fig. 111 (1923).]

Caespitose perennial $0.5-1$ metre high, without rhizomes, with a basal tuft of mainly extravaginal shoots about a third the height, and numerous culm leaves. Culms erect or slightly geniculate at the base, terete, $1-2 \mathrm{~mm}$ wide near the base, not compressible, slightly to moderately ribbed, glabrous or scabrous with minute tubercles; nodes $3-5(-8), \pm$ exserted, glabrous but sometimes with a band of sericeous hairs just below the node, c. $50 \%$ wider than the adjacent internodes. Leaf sheaths at first tightly enveloping the culm, later becoming loose; basal sheath $4.5-7 \mathrm{~mm}$ wide, slightly to moderately ribbed, glabrous to scaberulous with minute hairs or tubercles or, on the innovations minutely pubescent; inner margin glabrous; outer margin glabrous to sparsely ciliate with hairs $0.1-0.4 \mathrm{~mm}$ long, to $0.6 \mathrm{~mm}$ on the innovations; upper sheath $3-4.5 \mathrm{~mm}$ 
wide, moderately to strongly ribbed, scaberulous with minute tubercles to glabrous, inner margin glabrous, outer margin ciliate with hairs $(0.1-)$ $0.4-0.8 \mathrm{~mm}$ long or glabrous. Ligule truncate, membranous, $0.5-2 \mathrm{~mm}$ long, glabrous to sparsely ciliate, abaxial surface glabrous; auricles usually thickened and spreading, $0.7-1 \mathrm{~mm}$ long, ciliate at the base with hairs $(0.5-) 1-2 \mathrm{~mm}$ long. Leaf blade expanded to inrolled, $1-3 \mathrm{~mm}$ wide, to $30 \mathrm{~cm}$ long; abaxial surface moderately to strongly ribbed, scaberulous with minute tubercles or hairs; adaxial surface strongly ribbed, pubescent, scaberulous or puberulous with hairs to $0.2(-0.5) \mathrm{mm}$ long; collar glabrous, margins glabrous or sparsely ciliate with hairs to $0.5 \mathrm{~mm}$ long. Panicle $15-50 \mathrm{~cm}$ long, exserted, with distant fascicles of unequal, few-flowered, compound branches, open or occasionally contracted, 1-7 cm wide (excluding awns); axis terete to slightly angled, glabrous to scabrous or scaberulous with minute hairs or tubercles; branches $1-8 \mathrm{~cm}$ long, slightly angled to flattened, scabrous to scaberulous along the edges; pedicels 2-15 mm long, flattened, scabrous along the edges. Spikelets $10-15 \mathrm{~mm}$ long (excluding awn), gaping after floret disarticulation, otherwise tightly closed. Glumes subequal to unequal, acute to acuminate, transparent, straw-coloured or purple-tinged; lower glume $10-15 \mathrm{~mm}$ long, glabrous to minutely scabrous, hairs sometimes longer along the midrib, lower $25(-35) \%$ 3-nerved; upper glume $7-14 \mathrm{~mm}$ long, minutely scaberulous to glabrous, lower (15-) $20(-40) \% 5-$ nerved, upper (60-) $80(-85) \%$ 3-1-nerved. Floret narrow-cylindrical without a neck, 4-7 mm long (including callus). Lemma surface slightly granular to smooth, sericeous with hairs $0.3-0.6 \mathrm{~mm}$ long; lobes absent or $2,0.1-0.4 \mathrm{~mm}$ long, glabrous; coma obscure, of few hairs $0.4-1 \mathrm{~mm}$ long. Callus $1-3.5 \mathrm{~mm}$ long, sturdy, weakly bent at the tip, densely sericeous with white hairs to $0.8 \mathrm{~mm}$ long. Awn $45-100 \mathrm{~mm}$ long, falcate, c. $0.3 \mathrm{~mm}$ wide near the base; column $7-15 \mathrm{~mm}$ long, $5-10 \mathrm{~mm}$ to the end of the straight portion, strawcoloured to brown, scaberulous to scabrous with stiff hairs to $0.3(-0.4) \mathrm{mm}$ long; bristle scabrous with hairs to $0.2 \mathrm{~mm}$ long. Palea \pm equal to the lemma, acute to obtuse, smooth to slightly granular down the centre, sericeous down the centre back. Lodicules 3;2 abaxial membranous, 1-2 mm long, oblong; paleal c. $0.7 \mathrm{~mm}$ long, acute. Anthers penicillate, 2-3 mm long. Caryopsis (2-) 3-4 mm long; embryo $20-30 \%$ the length; hilum $50-80 \%$ the length.

DistribuTION: Widespread in all southern mainland States including New South Wales.

Selected Specimens: Queensland: Darling Downs: roadside at Wallangarra, Qld. border, Hilton, 4.2.1945 (ADW 4404).

NEW South WaLES: Southern Tablelands: Charnwood, c. $15 \mathrm{~km} \mathrm{NW.} \mathrm{of} \mathrm{Canberra,} \mathrm{Crisp} \mathrm{2294,}$ 31.10.1976 (CBG, NSW); Acton, Canberra, Beeton CBG 064049, 23.11.1970 (CBG); Kambah Pool, Boden CBG 041941, 1.1969 (CBG); Molonglo \& Murrumbridgee Rivers, Gauba CBG 057374, 8.12.1954 (CBG); Bredbo, Murray NSW 117138, 12.1913 (NSW); Eucumbene, Phillips CBG 018931, 27.1.1965 (CBG); Cooma, Vickery NSW 117139, 2.1930 (NSW); 13 miles [21 km] from Maffra towards Ando, Carrol CBG 024816, 5.12.1965 (CBG); Bibbenluke district, Cleland NSW 117140, 5.1913 (NSW). South Western Slopes: Grong Grong, Johnson NSW 117145, 25.5.1947 (NSW); 7 miles [11 km] N. of Wagga Wagga, Phillips CBG 025458, 20.10.1965 (CBG); 4 miles [6 km] E. of Henty, Flynn 62, 6.11.1970 (NSW); Comer Reserve, 6 miles [10 km] SW. of Henty, McBarron 5623 , 25.10.1951 (NSW); Walbundrie, McBarron 3193, 29.3.1949 (NSW); Walla Walla, McBarron 5563, 4.10.1951 (NSW); Burrumbuttock, McBarron 2738, 3.12.1948 (NSW); Balldale, McBarron 4791, 25.8.1950 (NSW); Jindera, McBarron 2652, 24.11.1948 (NSW); Wymah, McBarron 5770, 29.11.1951 (NSW); Albury, McBarron 2633, 21.11.1948 (NSW).

SOUTH Australia: Lake Eyre Basin: Wintinna Creek, 18 miles [29 km] N. of Mt Willoughby, Beauglehole 20201, 7.10.1966 (NSW); Mt Livingston, Langley NSW 116663, 10.1897 (NSW, K). Gairdner-Torrens Basin: 'Oakden Hills' Station, Gill NSW 117117, 2.1904 (NSW). Flinders Ranges: c. $1 \mathrm{~km} \mathrm{~N}$. of Nudlamutana Well, Whibley 2167, 26.10.1967 (AD, NSW); nr. Blinman, Blake 16900, 31.8.1946 (BRI); Oraparinna National Park, Symon 7579, 9.10.1971 (ADW, CANB); Wilpena to Bunyeroo, Blackburn, 3.10.1954 (ADW 44154); Wilpena Pound, Cleland, 10.11.1928 (AD); Crisp 
917, 22.10.1974 (CBG); 22 miles [35 km] S. of Hawker, Hilton, 8.4.1955 (ADW 44086); 'Portacoona' Station Homestead, c. 18 miles [29 km] SW. of Hawker, Tindale NSW 117072, 24.8.1969 (NSW); Boolcunda East, Hilton NSW 116662, 1.10.1954 (ADW, NSW); Pichi Richi Pass, Blake I6863, 29.8.1946 (BRI); Quorn, Crocker, 18.9.1939 (ADW 4594); 10 miles [16 km] N. of Carrieton, Hilton, 1.10.1954 (ADW 44146); Horrocks Pass, Hilton, 12.1951 (ADW 44046); 16 km W. of Peterborough, Crisp 589, 9.9.1963 (CBG). Eastern: 'Bilbliando' Station, c. $50 \mathrm{~km}$ E. of Hawker, Crisp 888, 19.10.1974 (BRI, CBG, NSW); Koonamore, Crisp 594, 15.9.1973 (CBG); Yunta to Koonamore, Symon 19.12.1954 (ADW 28117); Winnininnie, near Manahill, Reid, 5.10.1954 (ADW 44160); $6 \mathrm{~km}$ NE. of Oodlawirra, Lothian 1170, 4.11.1962 (AD, NSW). Eyre Peninsula: Gawler Ranges nr. Waltinga Dam, Symon 8176, 5.10.1972 (ADW); 10 miles [15 km] N. of 'Nonning' Station, Specht \& Carrodus 27, 14.11.1958 (AD); S. of Mt Gairdner, c. 55 km WNW. of Nonning, Carrick 2382, 29.9.1969 (BRI); Port Germein Gorge, Burbidge, 29.8.1946 (CANB 19551); Cleland, 20.10.1953 (ADW 44060); Port Germein, Hilton, 12.9.1951 (ADW 43990); Colton, Crocker, 11.10.1944 (CANB 11637); Cowell Flats, French, 12.1954 (ADW 28154); Mittalie, c. 10 miles [13 km] NW. of Cowell, Pearce, 28.1.1965 (ADW 44119); Cleve [as Cleeve], Phillips 458, 20.9.1965 (CBG); Port Lincoln, Black NSW 117112, I17113, 11.1903 (NSW). Northern Lofty: Port Pirie, Koch NSW 116660, 9.1901 (NSW); Deep Creek, 5 miles [8 km] E. of Burra, Hilton, 24.8.1946 (ADW 43928); 6 miles [10 km] N. of Bute on Wokurna road. Tindale 408, 10.9.1970 (NSW); Mortlock Experimental Station near Mintaro, Symon 4447, 9.11.1966 (ADW, CANB); 8 miles [13 km] S. of Port Wakefield at Inkerman, Phillips CBG 043562, 2.10.1965 (CBG); Oakley Hill, Owen, Beck, 2.1942 (ADW 4694); 2 miles [3 km] SW. of Mallala, Moore, 10.10.1969 (CANB 249734). Murray: Morgan, Steward, 16.10.1965 (ADW 37510); Black Hill, 18 miles [29 km] SE. of 'Sedan', Hilton NSW 117076, 22.9.1951 (ADW, NSW); 1 mile [1.6 km] E. of Kanmantoo, Hilton, 18.3.1954 (ADW 44053). Yorke Peninsula: Kadina, Beck, 2.1942 (ADW 4696); Melton, Reid NSW 117075, 30.9.1954 (ADW, NSW); Winulla Road, Arthurton, Beck, 2.1942 (ADW 4704); 1 mile [1.6 km] N. of Arthurton, Phillips CBG 037669, 17.10.1966 (CBG). Southern Lofty: Reeves Plain, Beck, 2.1942 (ADW 4701); Highbury, Kraehenbuehl 822, 22.10.1962 (BRI); Lockleys, c. 6 km W. of Adelaide, Smith 1061, 8.12.1967 (AD); 6 miles [10 km] SE. of Nairne, Hilton, 20.11.1953 (ADW 44037); Waterfall Gully, Adelaide Hills, Hilton, 12.10.1944 (ADW 37510); Belair Road, Adelaide Hills, Hilton, 13.10.1945 (ADW 43897); Plympton, Hilton, 5.9.1946 (ADW 43983); Torrens Gorge, Hilton, 8.10.1946 (ADW 44159); South Parklands, King William Road, Adelaide, Cleland, 25.10.1955 (ADW 13280); Brown Hill Creek, Adelaide Hills, Hilton, 13.10.1945 (ADW 43985); Forest Lodge, Verdun, 3 miles [5 km] SW. of Balhanna, Hilton NSW 117073, 5.12.1953 (ADW, NSW); N. of Willunga, Hilton, 20.10.1946 (ADW 43993); nr. Waterfall Creek, head of Yankalilla, Hilton, 25.11.1953 (ADW 44123). South-eastern: Devils Elbow, Mt Barker Road, E. of Glen Osmond, Hilton 8.10.1946 (ADW 44174).

\section{Stipa nullarborensis J. Vickery, S.W.L. Jacobs \& J. Everett, sp. nov.}

$S$. breviglumi affinis sed palea longitudine $4 / 5$ lemmatis partes aequantia (breviglumi: 1/2-3/5), callo pungenti, lemmatibus usque ad apicem pilis relatis, collo lemmatis nullo, differt.

Holotype: Western Australia: Abrakurrie Cave, 18 miles [29 km] NW. of Eucla. Open depression near entrance to cave. A.C. Beauglehole 13395, 23.9.1965 (NSW; isotypes CANB, PERTH).

Perennial to c. 1 metre tall, with a short rhizome and usually with few basal leaves. Culms branched or simple, terete, $1(-3) \mathrm{mm}$ wide near the base, not compressible, glabrous to scaberulous or scabrous, especially just below the nodes; nodes 4-5, glabrous, exserted. Leaf sheaths $5(-8) \mathrm{mm}$ wide, loose, glabrous to pubescent, smooth to scaberulous or scabrous, upper sheaths generally less hairy; margins similar to adjacent surfaces. Ligule truncate, papery, easily torn, 2-3 mm long, glabrous; auricle glabrous. Leaf blade usually expanded, 2-5 mm wide, to $25 \mathrm{~cm}$ long; abaxial surface scaberulous, scabrous to sparsely pubescent; adaxial surface scabrous and/or sparsely pubescent; margins glabrous or with antrorsely hooked tubercules. Panicle to $30 \mathrm{~cm}$ long, to $3 \mathrm{~cm}$ wide (excluding awns), exserted, contracted, with distant fascicles of sparsely to densely flowered unequal compound branches; axis slightly angular, glabrous or scabrous; branches angular, 2-8 cm long, scabrous or pubescent; pedicels 
flattened, 1-7 mm long, scabrous or pubescent. Spikelets gaping, 4-5.5 mm long (excluding awn). Glumes equal, obtuse to broad-acute, often purple-tinged, with stiff appressed hairs; tips ciliate, easily torn; lower glume 4-5.5 mm long, lower $50 \%$ 3-nerved; upper glume $4-5.5 \mathrm{~mm}$ long, lower $50 \% 5$-nerved, the next $35 \%$ 3-nerved. Floret narrow-fusiform, 3-4 mm long (including callus), not tapering apically to a discernible neck. Lemma slightly granular, brown at maturity, with soft, spreading, white hairs right to and slightly overlapping the base of the awn; coma absent; lobes 2 , c. $0.1 \mathrm{~mm}$ long, or absent. Callus sharp and strongly curved, $0.5-0.8 \mathrm{~mm}$ long, similarly hairy to the lemma. Awn c. $0.15 \mathrm{~mm}$ wide near the base, (14-) 20-30 mm long, slightly twice bent; column (6-) 9-13 mm long, (3-) 5-8 mm to the first and less-developed bend, light brown, scaberulous with hairs to $0.1 \mathrm{~mm}$ long; bristle scaberulous, often purple-tinged and darker than the column. Palea broad-acute, ciliate, $80 \%$ the length of the lemma with similar surface and indumentum. Lodicules 2-3, membranous; 2 abaxial, $0.7-0.9 \mathrm{~mm}$ long, obtuse; paleal acute, $0.3 \mathrm{~mm}$ long, or absent. Anthers $1.5-1.7 \mathrm{~mm}$ long, lightly penicillate. Mature caryopsis not seen, apparently $2 \mathrm{~mm}$ long.

Distribution: Nullarbor Plain in Western Australia.

SPECIMENS EXAMINED: WESTERn Australia: Eucla: Abrakurrie Cave, 18 miles [29 km] NW. of Eucla, Beauglehole 13395, 23.9.1965 (CANB, NSW, PERTH); 'Madura' Homestead, Willis, 30.8.1947 (BRI 229382, MEL 59887); 3.5 miles [5.5 km] E. of Eucla, George 8512, 15.10.1966 (PERTH, 2 sheets); c. $1 \mathrm{~km}$ N. of Eucla, Nullarbor Plain, Beauglehole 49443, 30.8.1974 (CANB, NSW).

The specific epithet refers to the Nullarbor Plain where this species occurs.

Similar to $S$. breviglumis but differing in the longer palea (relative to the lemma), the sharp callus, the hairs of the lemma continued to its apex and the absence of a neck to the lemma. Differs from $S$. acrociliata in the smaller spikelet and in the equal glumes.

Stipa nullanulla J. Everett \& S.W.L. Jacobs, Telopea 2(4): 398 (1983).

Holotype: New SOUTH WALES: 'Nulla Nulla', $2 \mathrm{~km}$ south of gate at northern end of Bluff paddock. Saltbush, mallee, Myoporum sp. Everett 133 \& Jacobs, 25.11.1980 (NSW; isotype AD).

Small caespitose perennial $0.4-0.5$ metres high with a loosely contracted rootstock. Culms erect, 1-2 $\mathrm{mm}$ wide near the base, terete, smooth, mostly glabrous but pubescent just below the nodes; nodes 2, glabrous, rarely exserted. Leaf sheaths broad, loose around the culm, glabrous or the lower sheaths scaberulous to pubescent between the nerves; outer margin densely woolly especially on lower sheaths; inner margin sparsely woolly. Ligule $1-5(-10) \mathrm{mm}$ long, membranous, laciniate, with woolly cilia to $9 \mathrm{~mm}$ long on tips and back. Leaf blades linear, usually rolled, rigid, to $30 \mathrm{~cm}$ long and 2-3 mm wide; abaxial surface unribbed, very finely scaberulous; adaxial surface strongly ribbed, the ribs covered with short hairs; margins strongly scabrous. Panicle 13-19 cm long, delicate and spreading, axis very sparsely scabrous with distant fascicles of unequal compound branches; branches 4-60 cm long. scabrous, scaberulous or shortly pubescent; pedicels similar to the branches, 3-15 $\mathrm{mm}$ long. Spikelets narrowly gaping at maturity, widely gaping after floret disarticulation, 9-11 mm long (excluding awn). Glumes subequal, green at the base, chartaceous at the tip, 3 nerves visible for much of the length, acute to shortly acuminate; lower glume $9-11 \mathrm{~mm}$ long, the lower $75 \%$ 3-nerved; upper glume 8-10 $\mathrm{mm}$ long, the lower $25 \%$ 5-nerved, the next $50 \%$ 3-nerved. Floret cylindrical to narrow- 
fusiform, 5-6 mm long (including callus). Lemma at maturity tightly convolute, smooth with an antrorsely scabrous neck, glabrous to very sparsely scattered with slightly spreading yellow hairs, dark brown with the 5 nerves pale yellow; coma sparse, $1-1.5 \mathrm{~mm}$ long in 2 tufts; lobes absent. Callus straight, $2.0-2.7 \mathrm{~mm}$ long, sericeous with yellow-brown hairs. Awn $0.25 \mathrm{~mm}$ wide near the base, $50-70 \mathrm{~mm}$ long, gently twice bent; column $18-25 \mathrm{~mm}$ long, $10-15 \mathrm{~mm}$ to the first bend, shortly pubescent with hairs to $0.2 \mathrm{~mm}$ long; bristle scabrous. Palea acute to obtuse, subequal to the lemma, glabrous or with a sparse apical tuft. Lodicules 3, membranous, oblong; 2 abaxial c. $1 \mathrm{~mm}$ long; paleal minute or rarely equal in size to the palea and then similar in texture to the palea. Caryopsis 2.7-3.0 mm long; embryo $25-35 \%$ the length; hilum $65-75 \%$ the length.

Distribution: South Far Western Plains of New South Wales and west into South Australia.

SPECIMENS Examined: New SOUTH WALES: South Far Western Plains; 'Nulla Nulla' unit 37, Stanley $1784,3.12 .1975$ (NSW).

SOUTH Australia: Murray: c. 32 miles [50 km] N. of Overland Corner, Symon 3728 (ADW).

Apparently restricted to gypseous rises. Palatable to sheep and rabbits and now confined to the shelter of shrubs and similar protected places.

Stipa oligostachya Hughes, Kew Bull. 1921: 12 (1921).

HOLOTYPE: VictoRia: Wando Vale [as Wendu Vale], growing in tussocks, Robertson 534 (K!).

Caespitose perennial to 1 metre high with conspicuously extravaginal shoots and a short rhizome. Culms erect, $1(-2) \mathrm{mm}$ wide near the base, not compressible, scarcely ribbed, glabrous, scaberulous or puberulous, pubescent just below the nodes; nodes c. 3 , just exserted or concealed, sericeous, to $25 \%$ wider than adjacent internodes. Leaf sheaths tightly enveloping the culms, 2 $(-4) \mathrm{mm}$ wide, ribbed, glabrous; basal sheaths lanate; outer margin shortly ciliate, densely ciliate near the orifice. Ligule ovate to truncate, coriaceous, 0.5-2 mm long, often continuous with the sheath margin, ciliate with long hairs, sericeous on the back; auricles thickened and spreading, with short hairs that usually continue as a line around the collar. Leaf blades usually tightly rolled, erect, to $20 \mathrm{~cm}$ long, $0.5-1.0 \mathrm{~mm}$ wide; abaxial surface unribbed or slightly ribbed, glabrous to minutely scaberulous, occasionally with widely scattered hairs; adaxial surface ribbed, minutely puberulous to hirsute. Panicle $10-25 \mathrm{~cm}$ long, exserted with distant fascicles of unequal few-flowered compound branches, spreading, 2-4 cm wide (excluding awns); axis terete, scaberulous to scabrous upwards; branches to $6 \mathrm{~cm}$ long, angled to flattened upwards, scabrous on the edges; pedicels $3-12 \mathrm{~mm}$ long, angled to flattened upwards, scabrous on the edges. Spikelets $11-17 \mathrm{~mm}$ long (excluding awn), gaping. Glumes slightly unequal, broad and slightly inflated at the middle (at least the lower), acuminate or acute, firm and purple-tinged at the base, hyaline at the tip, glabrous, or scaberulous towards the margins; lower glume 11-17 mm long, lower 50\% 3nerved; upper glume 10-15 mm long, lower 30\% 5-nerved, next 20\% 3-nerved. Floret $7-9 \mathrm{~mm}$ long (including callus), fusiform to cylindrical, with a welldefined neck, deep reddish brown at maturity, the surface glistening with translucent antrorsely hooked tubercules, the midrib thickened, glabrous on the upper half, but with sparse, stiff, spreading yellow hairs over the nerves and on the lower half; coma absent; lobes $1-2,0.1-0.35(-0.6) \mathrm{mm}$ long. Callus sturdy, straight, 2-3 mm long, sericeous with hairs darker than the lemma. Awn $55-70 \mathrm{~mm}$ long, twice bent, $0.3-0.5 \mathrm{~mm}$ wide near the base; column $18-25 \mathrm{~mm}$ 
long, 9-12 $\mathrm{mm}$ to the first and stronger bend, pubescent with hairs $0.25-0.4$ $(-0.8) \mathrm{mm}$ long; bristle scabrous, very slightly curved. Palea \pm equal to the lemma, acute, coriaceous, hyaline on the edges, granular down the centre, glabrous or with sparse hairs down the centre and at the tip. Lodicules 3 , membranous; 2 abaxial oblong to narrow-cuneate, $1.5-1.8 \mathrm{~mm}$ long; paleal oblong to triangular, $0.8-1.0 \mathrm{~mm}$ long. Anthers $2.5 \mathrm{~mm}$ long, penicillate. Mature caryopsis not observed, apparently 3-4 mm long.

Distribution: South-western Victoria and the Southern Lofty Region of South Australia.

Specimens Examined: Victoria: Region C: Mt Arapiles, Corrick 1407, 24.11.1968 (NSW), Beauglehole 7448, 23.11.1964 (NSW). Region D: Northern end, E. of Dundas Range, Beauglehole 29934, 5.12.1968 (NSW, MEL); nr. Hamilton, Corrick 1552, 8.12.1968 (Corrick herb.). Region J: Creswick, c. 4 miles [6 km] NW. of township, Willis, late Nov. 1930 (MEL 59926); Cockajemmy Lakes, Beauglehole 61605, 17.11.1978 (NSW); Narrapumelap, Beauglehole 61632 (NSW).

South Australia: Southern Lofty: Belair, Cleland, 26.11.1932 (AD 97421208); Mt Barker, Liebelt, 1936 (AD 97420218); Myponga, Hilton, 10.10.1946 (ADW 44013); Callawonga Creek, Hilton, 25.11.1953 (ADW 44121, 44125, 44128).

\section{Stipa petraea $J$. Vickery, Telopea 2: 15 (1980).}

Holotype: South AustraliA: Flinders Ranges: Brachina Gorge, Oraparinna National Park, western portion, J.Z. Weber 2577, 18.9.1971 (AD).

Caespitose perennial $0.5-1$ metre high, shortly rhizomatous with a basal tuft to c. $60 \%$ the height. Culms erect, terete, $1.5-2 \mathrm{~mm}$ wide near the base, \pm compressible, slightly ribbed, blabrous; nodes 3-5, exserted with age, sericeous with hairs $0.2-0.5 \mathrm{~mm}$ long, $25-75 \%$ wider than the adjacent internodes. Leaf sheaths not inflated, slightly ribbed, glabrous; basal sheath c. $10 \mathrm{~mm}$ wide; upper sheath c. $5 \mathrm{~mm}$ wide; margins glabrous; collar glabrous. Ligule truncate, 0.1-1 mm long, membranous, densely ciliate with hairs $0.5-2 \mathrm{~mm}$ long; auricle absent. Leaf blade weakly rolled to folded, c. $1.5 \mathrm{~mm}$ wide, to $50 \mathrm{~cm}$ long; abaxial surface moderately ribbed, glabrous but strongly ribbed on the innovations with minute tubercles in the grooves; adaxial surface strongly ribbed, pubescent at the base with hairs $0.1-0.5 \mathrm{~mm}$ long, minutely scaberulous upwards. Panicle c. $25 \mathrm{~cm}$ long with distant fascicles of few-flowered branches (only immature specimens seen); axis slightly flattened with sparse hairs 0.05-0.1 mm long along the edges; branches 3-7 cm long, angled, scabrous along the edges with hairs $0.1-0.2 \mathrm{~mm}$ long; pedicels $1-2.5 \mathrm{~cm}$ long, angled, scabrous with hairs $0.1-0.3 \mathrm{~mm}$ long. Spikelets $11-15 \mathrm{~mm}$ long (excluding awn), gaping at maturity. Glumes equal to unequal, acute to acuminate, minutely scabrous; lower glume 11-15 mm long, lower 20-40\% (4-) 6-nerved, upper $60-80 \%$ 5-1-nerved; upper glume 11-13 mm long, lower (25-) 35-50\% 5 (-6)nerved, upper 50-65 (-75)\% (5-) 3-1-nerved. Floret fusiform, 7-9.5 mm long (including callus), without a neck. Lemma surface smooth to granular, densely sericeous with orange hairs $0.5-1.5 \mathrm{~mm}$ long; lobes $2,1.5-2.5 \mathrm{~mm}$ long, acute, sericeous; coma to $2.5 \mathrm{~mm}$ long. Callus $1-1.5 \mathrm{~mm}$ long, weakly bent at the tip, densely sericeous with orange hairs $0.3-0.8 \mathrm{~mm}$ long. Awn $40-55 \mathrm{~mm}$ long, twice bent, $0.3 \mathrm{~mm}$ wide near the base; column $20-25 \mathrm{~mm}$ long, $10-15 \mathrm{~mm}$ to the first bend, straw-coloured, scabrous with hairs to $0.3 \mathrm{~mm}$ long; bristle strawcoloured, scabrous with hairs to $0.1 \mathrm{~mm}$ long. Palea equal to the lemma, bilobed, slightly depressed between the nerves, granular to smooth, densely sericeous with orange hairs 1-1.5 mm long, margins glabrous. Lodicules $3 ; 2$ abaxial membranous, $1-1.3 \mathrm{~mm}$ long, obtuse; paleal membranous, $1-1.2 \mathrm{~mm}$ long, acute. Anthers 4.5-5 mm long, penicillate. Caryopsis not seen. 
Distribution: Apparently endemic to the Flinders Ranges and the Eastern Region close to the Ranges in South Australia.

Specimens EXamined: South Australia: Eastern: Mt Chambers Gorge, Filson 3476, 7.10.1960 (MEL). Flinders Ranges: Oratunga Ck., NNW. of Blinman, Ising, 1.10.1918 (AD); Oraparinna National Park, Brachina Gorge, Symon 2558, 8.10.1971 (ADW, CANB); Bunyeroo Gorge, Everett 262, 263, 16.9.1981 (NSW); Horrocks Pass, Hilton, 12.9.1951 (ADW 44045, 44044).

Very similar to $S$. juncifolia but differs in the slightly less rigid leaves; the shorter plants; the shorter, obtuse, densely ciliate ligule; the axis, branches and pedicels scabrous, the glumes lightly scabrous on the nerves; the rather longer and rather more broadly fusiform lemma covered with hairs that become distinctly orange.

Stipa pilata S.W.L. Jacobs \& J. Everett, sp. nov.

Differt a $S$. trichophylla foliis latioribus pungentibusque, arista et gluma inferiore breviore.

Holotype: South Australia: Murray: Monarto City Centre site, Lake site area, growing under mallee, D.E. Symon 9072, 26.11.1974 (NSW; isotype ADW).

Caespitose perennial to 0.85 metres high with a sparse basal tuft of extravaginal shoots. Culms erect, scarcely compressible, terete, $0.8-1 \mathrm{~mm}$ wide near the base, smooth to slightly ribbed, densely pubescent to pilose just below the nodes; nodes $2-3$, exserted, to $30 \%$ broader than adjacent internodes, pubescent to almost glabrous. Leaf sheaths tightly enveloping the culms, 2-4 mm wide; lowermost sheaths densely pubescent with long and short hairs with upper sheaths pubescent, finely scabrous or glabrous; inner margin glabrous; outer margin long-ciliate. Ligule 1-2 mm long, truncate or shortly laciniate, membranous, ciliate, densely pubescent on the back, auricles thickened and pilose with a tuft of long straight hairs 1-2 mm long. Leaf blades to $12 \mathrm{~cm}$ long, erect, pungent or almost so, tightly inrolled, coarse, $0.8-2 \mathrm{~mm}$ diameter; abaxial surface scarcely ribbed, densely scabrous with short stiff hairs and occasionally with longer stiff hairs; adaxial surface ribbed, densely pubescent with short hairs. Panicle to $20 \mathrm{~cm}$ long, exserted, contracted, $2-3 \mathrm{~cm}$ wide (excluding awns), moderately dense with close fascicles of few, manyflowered branches; axis terete, minutely scabrous to almost glabrous; pedicels to $8 \mathrm{~mm}$ long, very slender, flattened, scabrous to almost glabrous. Spikelets 8-10 mm long (excluding awn), slightly gaping after floret disarticulation. Glumes subequal, acuminate, yellow-cream, transparent and membranous; lower glume 8-10 mm long, the lower 30\% 3-nerved; upper glume 7-9 $\mathrm{mm}$ long, the lower 30\% 5-nerved, the next 20\% 3-nerved. Floret linear to fusiform, 4-5 mm long (including callus). Lemma finely tuberculate, gold-brown at maturity, the nerves slightly paler, with white, erect hairs, sparse especially at the apex; coma in 2 tufts c. $1 \mathrm{~mm}$ long, although obscured by hairs on the awn; lobes absent. Callus 1-1.5 mm long, straight and fine, with dense white hairs. Awn 40-50 mm long, $0.2-0.25 \mathrm{~mm}$ wide near the base, falcate; column 7-11 mm long, densely pubescent with spreading hairs $0.2-0.5 \mathrm{~mm}$ long; bristle scaberulous. Palea c. $0.5 \mathrm{~mm}$ shorter than the lemma, obtuse, coriaceous down the centre with a line of white hairs; margins and tip hyaline and glabrous. Lodicules 2, abaxial, membranous, $1-1.5 \mathrm{~mm}$ long, slightly spathulate. Anthers not reliably observed. Caryopsis 2.7-3 mm long; embryo c. $30 \%$ the length; hilum c. $60 \%$ the length.

DistRIBUTION: Flinders Ranges, Northern Lofty and Murray Regions of South Australia. 
Specimens Examined: South Australia: Flinders Ranges: 2 miles [ $3 \mathrm{~km}]$ E. of Parachilna, Beauglehole 20903 p.p., 18.10.1966 (NSW); Brachina Gorge, Symon 7569, 8.10.1971 (NSW, dupl. of ADW 47740). Northern Lofty: Bundaleer Hills, Black, 3.11.1925 (AD 97422275). Murray: Monarto, Symon 9077, 26.11.1974 (NSW, ADW).

The specific epithet refers to the long hairs present on the leaves and awns.

Differs from other Stipa species with falcate awns in the pungent leaves. Differs from $S$. trichophylla in the broader, pungent leaves and in the shorter awn and lower glume.

Stipa platychaeta Hughes, Kew Bull. 1921: 16 (1921), ibid. 1922: 17 (1922); Black, Fl. S. Austral. edn 2: 89 (1943); Gardner, Fl. W. Austral. 1, Gram.: 177-8 (1952); Willis, Handb. Pl. Victoria 1: 183 (1962), edn 2: 183 (1970).

Holotype: Western Australia: Lake Cowcowing, Koch 1133 p.p. (K!). The specimen at $\mathrm{K}$ is undated. There are two specimens at PERTH dated 9.1904, and two specimens at NSW bearing the same number but dated respectively 9.1904 and 10.1904 (NSW 116298, 116299) both having been separated from collections of $S$. elegantissima bearing the same number. All specimens match the Holotype at K but they cannot all be duplicates of the Type.

[S. acrociliata var. minor Reader, Victorian Naturalist 23: 25 (1906), nomen nudum. A specimen (MEL 60037) is so named in Reader's handwriting from 'mallee, Borung, F. M. Reader, 25.10.1901'.]

Diffuse or caespitose, wiry perennial $0.5-2$ metres high, shortly rhizomatous, without a basal tuft of leaves. Culms erect or slightly geniculate at the base, occasionally branched, terete, $1-2.5 \mathrm{~mm}$ wide near the base, not compressible, smooth to strongly ribbed, glabrous; nodes $2-10$, exserted, if swollen then to $50 \%$ larger than the adjacent internodes. Leaf sheaths not inflated, 3-10 mm wide; basal sheath slightly to strongly ribbed, glabrous to scabrous with minute tubercles; upper sheath strongly to moderately ribbed, glabrous to scabrous with minute tubercles or hairs to $0.2 \mathrm{~mm}$ long; margins glabrous; collar glabrous. Ligule membranous, obtuse to broadly laciniate, $1-6 \mathrm{~mm}$ long, glabrous; abaxial surface glabrous; auricles thickened, 1-1.5 mm long, glabrous. Leaf blade expanded or weakly rolled, $1-8 \mathrm{~mm}$ wide, to $25 \mathrm{~cm}$ long, linear to narrowtriangular; abaxial surface strongly ribbed, scabrous with minute tubercles to glabrous; adaxial surface strongly to moderately ribbed, glabrous or with sparse hairs $0.1 \mathrm{~mm}$ long; margins glabrous to minutely scabrous. Panicle $10-40 \mathrm{~cm}$ long, exserted at maturity, spreading, to $20 \mathrm{~cm}$ wide (excluding awns) at maturity with distant fascicles of unequal, few-flowered, compound branches, $1-2.5 \mathrm{~cm}$ wide (excluding awns); axis terete, strongly ribbed, glabrous; branches $3-10 \mathrm{~cm}$ long, angled, with sparse hairs minute- $0.2(-0.6) \mathrm{mm}$ long to glabrous; pedicels $2-10 \mathrm{~mm}$ long, angled, with sparse hairs minute- $-0.2 \mathrm{~mm}$ long. Spikelets $7.5-15 \mathrm{~mm}$ long, gaping at maturity. Glumes unequal, acuminate, glabrous to minutely scabrous, straw-coloured; lower glume $7.5-15 \mathrm{~mm}$ long, lower $5-30 \%$ 3-nerved; upper glume 6-10 (-12) mm long, lower 45-60\% 3-nerved. Floret cylindrical, 4.5-6 mm long (including callus), without a neck. Lemma granular, sericeous with hairs $0.05-0.3 \mathrm{~mm}$ long; lobes $2,0.1-0.2 \mathrm{~mm}$ long or absent; coma absent. Callus $0.5-1 \mathrm{~mm}$ long, almost straight, densely sericeous with hairs (0.1-) 0.3-0.5 (-0.7) $\mathrm{mm}$ long. Awn 60-80 (-90) mm long, falcate, $0.1-0.2 \mathrm{~mm}$ wide near the base; column 10-15 mm long, brown, scabrous along the edges with hairs to $0.1 \mathrm{~mm}$ long; bristle delicate, strongly flattened, scabrous along the edges with hairs minute- $0.2 \mathrm{~mm}$ long. Palea $60-80 \%$ the length of the lemma, acute, granular with hairs $0.2-0.4 \mathrm{~mm}$ long down the centre, margins glabrous. 
Lodicules $3 ; 2$ abaxial membranous, $0.5-2.5 \mathrm{~mm}$ long, acute; paleal membranous, 1-2 mm long, acute. Anthers $1.5-2 \mathrm{~mm}$ long, not penicillate. Caryopsis 3-3.5 mm long; embryo 20-25\% the length; hilum 50-70\% the length.

DisTRIBUTION: Plains of New South Wales and north-western Victoria, across all but the far north of South Australia to just into Western Australia. Usually on sandy soils in woodland or mallee.

Selected Specimens: New South Wales: Central Western Slopes: $19 \mathrm{~km}$ from Bogan Gate towards Forbes, Dunlop 1590, 2.9.1969 (CBG). North Western Plains: Nyngan, Blakely NSW $116239,10.1912$ (NSW). South Western Plains: Mount Hope, Holland, 10.1964 (CANB 176853); 1 mile [1.6 km] W. of Condobolin on North Euabalong road, Cunningham NSW 116233, 12.12.1971 (NSW); $30 \mathrm{~km} \mathrm{~N}$. of Garoolgan, Mulham 1246, 10.11 .1977 (NSW); c. $17 \mathrm{~km} \mathrm{E.} \mathrm{of} \mathrm{Griffith,} \mathrm{Binya}$ State Forest, Crisp 1637, 20.11.1975 (CBG). South Far Western Plains: $56 \mathrm{~km} \mathrm{~N}$. of Wentworth on road to Broken Hill, Rodd NSW 116232, 29.8.1969 (NSW); 8 km NW. of Bidura Homestead, Crisp 1788, 26.11.1975 (CBG, NSW); 'Nulla Nulla', Stanley 1795, 3.12.1975 (NSW).

VICTORIA: Region A: Mildura, Williamson, 10.1928 (MEL); Parish of Japaroo, c. 5 miles [8 km] S. of the 65-mile post on Sturt Highway, W. of Mildura, Willis, 3.9.1948 (MEL). Region B: Wyperfeld National Park, Beauglehole 29446 \& Finck, 11.11.1968 (NSW). Region C: Little Desert, Reader, 27.10.1891 (MEL 60766, p.p.); Wimmera, N. of Mt Arapiles, Dallachy, (MEL). Region F: c. $25 \mathrm{~km}$ SSW. of Robinvale, Beauglehole 56056, 2.5.1977 (MEL); $9 \mathrm{~km}$ SSE. of Robinvale, Beauglehole $56195,5.5 .1977$ (MEL). Region G: c. $12 \mathrm{~km} \mathrm{~N}$. of Manangatang, Beauglehole 55986, 30.4.1977 (MEL); Leaghur Forest, 15 miles [24 km] SSW. of Kerang. Beauglehole 40670, 1.10.1972 (NSW, MEL).

South Australia: Lake Eyre Basin: Upper Arkaringa Valley, Helms NSW 116238, 6.1891 (NSW). Nullarbor: Maralinga, Hill 598, 13.8.1956 (NSW); Knowles Cave, Symon 4658, 19.2.1967 (ADW, NSW). Gairdner-Torrens Basin: Bon Bon - Mount Eba netting on Stuart Highway, c. $80 \mathrm{~km} \mathrm{~N}$. of Kingoonya, Lay 466, 21.9.1971 (AD). Eastern: Koonamore, Osborn NSW 116314, 19.5.1923 (NSW). Eyre Peninsula: Reserve near Ceduna, Cleland, 7.9.1968 (AD); S. side of Salt Lake on Chaunceys Line, Cleland, 9.1962 (AD). Northern Lofty: Kulpara, Blaylock 779, 1.10.1967 (AD). Murray: Morgan to Burra Road, nr. Morgan, Cleland, 12.11 .1964 (AD); c. $3.5 \mathrm{~km} \mathrm{~S}$. of Monash, Eichler 13729, 19.4.1957 (AD); Swan Reach, Murray River, Cleland NSW 116310, 28.11.1913 (NSW); c. $8 \mathrm{~km}$ W. of Mannum, Spooner 2721, 24.2.1973 (AD). Yorke Peninsula: c. $6 \mathrm{~km}$ from Bute on Alford Road, Copley 774, 15.10.1966 (AD). Southern Lofty: 1 mile [1.6 km] from Kangaroo Flat on Kangaroo Flat-Mallala Road, Harris 42, 1.10.1959 (AD); c. 2.5 miles [4 km] WNW. of Gawler, Smith 957, 23.10.1967 (AD); Dry Creek, E. of Yatala Prison Farm, Kraehenbuehl 469, 13.9.1961 (AD); Northfield, Smith 1057, 3.12.1967 (AD).

Western Australia: Austin: Menzies, Andrews, 9.1902 (PERTH). Coolgardie: c. $80 \mathrm{~km} \mathrm{~N}$. of Kalgoorlie, Cleland, 30.8.1948 (AD 97219052); Broad Arrow, Fitzgerald, 9.1898 (NSW 116312); near Paddington, Gardner \& Blackall, 9.1927 (PERTH); Kalgoorlie, Maiden, 1909 (NSW 116313); 6 miles [10 km] W. of Southern Cross, Aplin 1975, 12.9.1962 (PERTH, K); 4 miles [6 km] W. of Eyre Hwy, on Hyden to Norseman Road, George 4349, 6.2 .1968 (PERTH); 14 miles [24 km] N. of Norseman on Coolgardie Road, Beauglehole 13519, 21.9.1965 (PERTH). Roe: c. 23 miles [38 km] E. of Fraser Range, Willis, 6.9.1963 (PERTH, duplicate of MEL 515037). Avon: Cowcowing, Koch 1133 p.p., 9.1904 (NSW 116299), 10.1904 (NSW 116298).

Stipa plumigera Hughes, Kew Bull. 1921: 20 (1921); Black, Fl. S. Austral. edn 2: 89 (1943).

HolotyPE: SOUTH Australia: Elder Exploring Expedition, Camp 10 (c. $\left.130^{\circ} 4^{\prime} \mathrm{E}, 27^{\circ} 16^{\prime} \mathrm{S}\right), R$. Helms, 29.6.1891 (K!; probable isotypes NSW 151321, 16019, 16020, 16021, MEL 59969, AD 97434003,97424088 in packet).

Synonym: S. eremophila var. dodrantaria J. Black, Trans. \& Proc. Roy. Soc. S. Austral. 46: 565 (1922); F1. S. Austral.1: 66 (1922). Holotype: South Australia: Camp 10, Birksgate Range, $R$. Helms, 29.6.1891 (AD 97424088 in part).

Caespitose perennial $0.4-0.6$ metres high, with conspicuously extravaginal shoots and a short rhizome. Culms erect, terete, $1-1.5 \mathrm{~mm}$ wide near the base, scarcely compressible, unribbed, smooth, glabrous or puberulous; nodes 2-3, seldom exserted, sparsely pubescent, to $30 \%$ broader than adjacent internodes. 
Leaf sheaths tightly enveloping culms. Ligule coriaceous, $0.5-2.5 \mathrm{~mm}$ long, broad-acute to truncate, densely ciliate; abaxial surface sericeous; auricles densely ciliate with $1 \mathrm{~mm}$ long straight hairs. Leaf blades to $35 \mathrm{~cm}$ long, usually expanded, 2-3 mm wide; abaxial surface slightly ribbed, glabrous to shortly pubescent with hairs to $0.5 \mathrm{~mm}$ long; adaxial surface deeply ribbed, pubescent with hairs $0.5-1 \mathrm{~mm}$ long; margin strongly antrorsely scabrous. Panicle sparse with close fascicles of uneven, few-flowered, compound branches, contracted to spreading, $15-20 \mathrm{~cm}$ long, $1.5-4 \mathrm{~cm}$ wide (excluding awns), exserted late; axis slender, terete, scabrous-pubescent; branches $3.5-7 \mathrm{~cm}$ long, angled, scaberulous; pedicels 4-18 mm long, angled to flattened, scaberulous. Spikelets 18-23 mm long (excluding awn), slightly gaping. Glumes pale yellow to purple, unequal, acuminate, membranous; lower glume $18-23 \mathrm{~mm}$ long, the lower $50 \%$ 3-nerved; upper glume 12-15 mm long, lower 30-50\% 5-nerved, the next $10-30 \%$ 3-nerved. Floret narrow-cylindrical with a slightly narrowed neck, 7.5-8.5 mm long (including callus). Lemma granular to almost smooth, with golden hairs to within $1-0.5 \mathrm{~mm}$ of the apex, the upper $1-0.5 \mathrm{~mm}$ scabrous; coma $0.5-0.8 \mathrm{~mm}$ long; lobes 2 , less than $0.1 \mathrm{~mm}$ long. Callus $2-3 \mathrm{~mm}$ long, with hairs similar to those of the lemma. Awn 70-110 mm long, $0.3-0.35 \mathrm{~mm}$ wide near the base, weakly twice bent, pale yellow; column 20-26 mm long, $15-20 \mathrm{~mm}$ to the first bend, densely pubescent with hairs $0.5-1 \mathrm{~mm}$ long; bristle often gently curved, villous for most of its length with hairs c. $1 \mathrm{~mm}$ long. Palea acute, $90 \%$ the length of the lemma, granular, ciliate, the very outer margin hyaline and glabrous. Lodicules 2, abaxial, membranous, narrow-oblong, $1 \mathrm{~mm}$ long. Anthers unequal, one $1.1 \mathrm{~mm}$, and the other two $0.5 \mathrm{~mm}$ long; florets cleistogamous. Caryopsis $3.5-4 \mathrm{~mm}$ long; embryo $30 \%$ the length; hilum $60-75 \%$ the length.

DisTRIBUTION: North-western South Australia and the Nullarbor Plain, extending into Western Australia.

SPeCimens Examined: South Australia: North-western: Elder Exploring Expedition, Camp 10, Helms, 29.6.1891 (K, NSW 151321, 16019, 16020, 16021; MEL 59969; AD 97434003, 97424088 in part); 10 miles [16 km] N. of Maralinga, Forde 592, 9.10.1956 (CANB); 69 miles [110 km] S. of Emu, Forde 528, 11.9.1956 (MEL, CANB, AD). Nullarbor: Maralinga, Forde 641, 12.10.1956 (CANB); within a mile [1 km] of Ooldea, Caulfield 130, 25.9.1955 (AD); limestone ridge behind Ooldea, Hilton, 24.8.1955 (ADW 19783); Ceduna, Canning 2339, 1.9.1968 (AD, CBG); Laura Bay, Rogers NSW 9323, 9.1907 (NSW).

Western Australia: Eucla: between Eucla \& Fowlers Bay, Richards (MEL 60925).

Stipa puberula Steudel, Syn. Pl. Glum. 1: 128 (1854); Gardner, Fl. W. Austral. 1, Gram.: 183 (1952), excl. synonym.

Holotype: 'Hrbr. Drummond coll. IV nr. 379, N. Holl.' in Steudel's herbarium (P!); duplicates of the Type Number at K and MEL (MEL 59971, 59972 and 59973). The Holotype sheet at P also bears a packet containing loose florets of an entirely different, large-fruited species of Stipa, possibly $S$. pubescens $\mathrm{R}$. Br. The foliage of the Type specimen is minutely puberulous in a manner more or less matched by only two or three of the specimens cited below, but we are convinced that this difference must be accepted as within the variability of indumentum of the species. The inflorescence of the Type is rather immature, and the hairs on the lemma are all white, whereas in the material here accepted as being conspecific the hairs on the lemma soon change to a characteristic tawny to dark brown. The size and shape of the lemma, however, with its characteristic scabrous neck, the delicate, rather short, twice bent awn, and the relatively short glumes, scarcely leave any doubt that these specimens must bear the name $S$. puberula however unsuitable the epithet may appear.

SYNONYM: S. arachnopus Pilger in Diels \& Pritzel, Bot. Jahrb. Syst. 35: 70 (1904); Hughes, Kew Bull. 1921: 15 (1921); Gardner, Fl. W. Austral. 1, Gram.: 179 (1952) excluding synonymy. 
Lectotype: Western Australia: Cited in the protologue as 'Hab. in distr. Coolgardie pr. Bullabulling in silvis apertis lapidoso-lutosis f1. m. Oct. (D [Diels] 5954)'. Prof. H. Scholz of the Botanischer Garten und Botanisches Museum, Berlin-Dahlem, has advised us that the Holotype is no longer in existence at B. There is a duplicate specimen labelled 'W. Australia: Dist. Coolgardie, Bullabulling, Diels n. 5954' in Diels' handwriting in MEL (MEL 59877) and we here designate this specimen as the Lectotype of $S$. arachnopus Pilger.

Caespitose perennial to c. 0.8 metres high with a sparse basal tuft of leaves to half the total height. Culms erect, c. $2 \mathrm{~mm}$ wide near the base, simple or occasionally branching, terete, compressible, ribbed, glabrous and smooth to puberulous, especially on the upper internodes and just below the nodes; nodes c. 3, densely to sparsely pubescent, exserted, to $50 \%$ wider than adjacent internodes. Leaf sheaths tight around the culms, c. $5 \mathrm{~mm}$ wide (although the uppermost a little broader), densely hirsute or puberulous to glabrous upwards; inner margin glabrous; outer margin densely woolly. Ligule firm, $0.2-0.5 \mathrm{~mm}$ long, truncate, ciliate; abaxial surface pubescent; auricles thickened, densely woolly. Leaf blades mostly rolled, flexuose, $1-2 \mathrm{~mm}$ wide, to $25 \mathrm{~cm}$ long; abaxial surface not ribbed, scaberulous, densely pubescent and sparsely to densely hirsute; adaxial surface strongly ribbed, sparsely hirsute to glabrous. Panicle spreading, exserted with distant fascicles of uneven branches bearing spikelets mainly at the ends, $15-30 \mathrm{~cm}$ long, $1.5-3 \mathrm{~cm}$ wide (excluding awns); axis terete, scaberulous; branches angular, to $8 \mathrm{~cm}$ long, scaberulous; pedicels $1.5-8 \mathrm{~mm}$ long, flattened, scaberulous. Spikelets $8-14 \mathrm{~mm}$ long (excluding awn), gaping. Glumes subequal, broad and inflated in the middle, firm and green to purple at the base, membranous and hyaline at the tip, glabrous or scaberulous on the nerves; lower glume $8-14 \mathrm{~mm}$ long, acuminate, lower $50 \%$ 3-nerved: upper glume $6-12 \mathrm{~mm}$ long, acute, lower $30 \%$ 5-nerved, the next $10-30 \% 3$ nerved. Floret turbinate to oblong-cylindrical, 4-6 (-6.5) $\mathrm{mm}$ long (including callus), usually with a neck. Lemma deep brown at maturity, the surface smooth, sericeous with dense fulvous hairs, the upper $0.5 \mathrm{~mm}$ glabrous to scabrous, hairy on the margins; coma of sparse stiff hairs $0.4-0.7 \mathrm{~mm}$ long; lobes less than $0.1 \mathrm{~mm}$ long. Callus $0.7-1.5(-1.8) \mathrm{mm}$ long, curved. Awn $0.2-0.25 \mathrm{~mm}$ wide near the base, $25-65 \mathrm{~mm}$ long, twice bent, pale throughout its length; column 15-20 mm long, 8-10 mm to the first bend, scabrous with hairs $0.05-0.10 \mathrm{~mm}$ long; bristle scabrous. Palea acute, subequal to the lemma (to $0.05 \mathrm{~mm}$ shorter), granular, sericeous with fulvous hairs down the centre. Lodicules 2, abaxial, membranous, oblong, $0.6 \mathrm{~mm}$ long. Anthers 0.6-2.0 mm long, penicillate. Caryopsis 2-5 mm long; embryo $30 \%$ the length; hilum $90 \%$ the length.

DistRIBUTION: South-western New South Wales and north-western Victoria, the Eyre Peninsula and Nullarbor Plain in South Australia, extending into Western Australia.

Selected Specimens: New South Wales: South Far Western Plains: E. of Balranald, Moulamein road, Henderson 422, 5.10.1947 (NSW); NE. of Lake Tooim, Henderson, 5.11.1947 (NSW 116973); Merran Ck., between Swan Hill \& Moulamein, Henderson 434, 16.11.1947 (NSW); Mellool, Henderson 433, 28.10.1947 (NSW).

Victoria: Region A: 5 miles [8 km] S. of 65-mile post on Sturt Hwy, Willis, 3.9.1948 (MEL 60693). Region H: County of Borung, Reader, 30.10.1904 (MEL 60712).

SOUTH Australia: Nullarbor: Hughes National Park, Ising 1636, 9.1920 (MEL, NSW, ADW, AD, BRI); nr. Koonalda Cave, Symon 4490, 16.2.1967 (K, CANB); 15 miles [24 km] from 'Nullarbor', Nundroo road, Phillips CBG 039487, 31.8.1968 (CBG). Eyre Peninsula: c. $20 \mathrm{~km}$ WNW. of 'Nonning', Carrick 2310, 26.9.1969 (AD); 1 mile [1.5 km] N. of 'Nonning', Specht \& Carrodus 18, 20, 14.11.1958 (AD). Murray: Mt Mary, 22 miles [35 km] E. of Eudunda, Ising, 4.10.1922 (ADW 43881). 
WESTERn Australia: Eucla: c. 115 miles [185 km] NW. of Reid, George 8478, 13.10.1966 (PERTH); 60 miles [96 km] N. of Loongana, Mitchell 86, 5.10.1974 (PERTH); 7 miles [11 km] W. of Deakin, Calaby, 24.10.1947 (CANB 15001); Reid, McCrumm, 7.1959 (PERTH); 8 km SW. of Loongana, Mitchell 68, 11.9.1974 (PERTH); $19 \mathrm{~km} \mathrm{W.} \mathrm{of} \mathrm{Eucla,} \mathrm{Beauglehole} \mathrm{49420,} \mathrm{30.8.1974}$ (CANB); Eucla, Batt, 1899 (MEL 60713). Coolgardie: c. 81 km W. of Cocklebiddy, Eyre Hwy.,

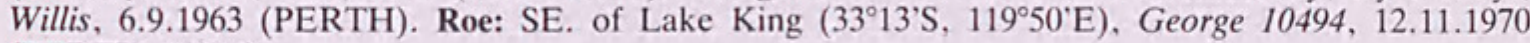
(PERTH, NSW).

$S$. puberula is closely related to $S$. eremophila but can generally be readily distinguished by its shorter floret, shorter and finer awn and shorter glumes.

Stipa pubescens $R$. Br., Prodr.: 174 (1810); Bentham, Fl. Austral. 7: 569 (1878); Moore \& Betche, Handb. Fl. N.S.W.: 484 (1893); Hughes, Kew Bull. 1921: 21 (1921), at least in part; ibid. 1922: 18 (1922); Willis, Handb. Pl. Victoria 1: 187 (1962), edn 2: 187 (1970); Beadle, Evans \& Carolin, Fl. Sydney Region: 657 (1972).

Lectotype. here designated: New South Wales: Port Jackson, R. Brown, 1802-5 (BM!, sheet II). The Type collection consists of three sheets. Sheets I and III contain mixtures of $S$. rudis and $S$. pubescens. Sheet II bears a good unmixed specimen that matches the description of $S$. pubescens; isolectotype (Iter Australiense 1802-5, R. Brown, no. 6203) at K.

Synonym: S. commutata Trin. \& Ruprecht, Mém. Acad. Imp. Sci. Saint-Pétersbourg, ser. 6, Sci., Math., Seconde Pt. Sci. Nat. 5: 49 (1842). Holotype: 'Nova Hollandia ad Portum Jackson, Sieber Agrostoth. n. 59' (LE, not seen). There is a duplicate of Sieber no. 59 in MEL (MEL 59974); it lacks fertile florets, but the long glumes, together with the stated locality, leave no doubt that it is a specimen of $S$. pubescens R. Br. Another duplicate of Sieber no. 59 is at K: it agrees completely with $S$. pubescens in glume length and foliage characteristics but lacks lemmas except for an imperfect one.

Caespitose perennial to 1.5 metres high with conspicuously extravaginal shoots from a short rhizome forming a loose tuft to half the height. Culms erect or occasionally geniculate near the base, not compressible, terete, $1-4 \mathrm{~mm}$ wide near the base, scarcely ribbed, finely pubescent for varying lengths below the nodes or the upper internodes glabrous to just below the nodes; nodes $2-3$, exserted, to $60 \%$ broader than adjacent internodes, densely sericeous. Leaf sheaths often purple-tinged, tight around the culms, c. $4 \mathrm{~mm}$ wide (occasionally the uppermost slightly inflated and to $8 \mathrm{~mm}$ wide), slightly ribbed, densely and finely pubescent or upper sheaths almost glabrous, the collar often hirsute; inner margin glabrous; outer margin densely ciliate with long hairs to sparsely ciliate especially on upper sheaths. Ligule coriaceous, 0.4-1 (-1.5) $\mathrm{mm}$ long, truncate or occasionally slightly obtuse, glabrous or ciliolate; auricles scarcely thickened, similar in pubescence to the sheath. Leaf blades tightly rolled or expanded, to $4 \mathrm{~mm}$ wide, to $50 \mathrm{~cm}$ long; abaxial surface scarcely ribbed, pubescent with minute hairs, or glabrous; adaxial surface ribbed, scarcely to densely pubescent with minute hairs; margins similar to adjacent surfaces. Panicle to $30 \mathrm{~cm}$ long, to $4 \mathrm{~cm}$ wide (excluding awns), exserted, loosely contracted to spreading, sparse with distant fascicles of few-flowered branches; axis slightly angular, densely and shortly scabrous; branches to $7 \mathrm{~cm}$ long, angular, scabrous to pubescent, especially on the angles, pedicels to $30 \mathrm{~mm}$ long, angular, scabrous to pubescent, especially on the angles. Spikelets (15-) 17-24 mm long (excluding awn), gaping widely. Glumes unequal, linear, often inrolled, firm, with nerves heavily overlaid with sclerenchyma, usually purple-tinged, occasionally pale green, pubescent overall or glabrous between the nerves and scabrous on the nerves, the margins ciliate; lower glume 17-24 mm long, the lower $95 \% 3$ nerved, the tip narrowly truncate and firm or occasionally slightly acute and 
chartaceous; upper glume 15-20 mm long, the lower 30-60\% 5-nerved, the next $65-35 \% 3$-nerved, the tip narrowly truncate and firm, rarely slightly acute and chartaceous. Floret cylindrical with a slight neck, (9.5-) 11-15 mm long (including callus). Lemma reddish brown at maturity, finely tuberculate, especially upwards, with sparse slightly fulvous hairs on the lower $50-60 \%$, glabrous upwards; coma absent; lobes absent. Callus (2.5-) 3-4.5 mm long, straight, the tip weakly bent with slightly fulvous hairs. Awn (60-) 70-100 mm long, $0.5-0.6 \mathrm{~mm}$ wide near the base, twice bent; column $45-70 \mathrm{~mm}$ long, $30-55 \mathrm{~mm}$ to the first bend, scaberulous to softly pubescent with dense hairs $0.05-0.15 \mathrm{~mm}$ long; bristle scabrous. Palea $50-70 \%$ the length of the lemma, obtuse or rarely acute, glabrous, granular down the centre, margins and apex hyaline to pale and chartaceous. Lodicules 2-3, membranous; 2 abaxial 1.5-2 mm long, oblong; paleal acute, c. $1 \mathrm{~mm}$ long, or absent. Anthers 2-6 mm long, not penicillate. Caryopsis 5-8 mm long; embryo $15-20 \%$ the length; hilum c. $90 \%$ the length.

DistRIBUTION: Sandstone areas of south-eastern Queensland and eastern New South Wales.

Selected Specimens: Queensland: Moreton: Mt Gravatt, Henderson 147, 20.11.1966 (BRI, CANB), Smith 316, 15.2.1938 (BRI); nr. Moggill, Hubbard 8596, 3.4.1931 (K, NSW); $4 \mathrm{~km} \mathrm{SW}$. of Victoria Point, Stanton, 10.11.1971 (BRI): $3 \mathrm{~km}$ E. of Plunkett, Simon \& Sharpe NSW 117038 , 18.11.1974 (NSW, BRI); Sunnybank, Blake 5I08, 20.1.1934 (BRI, K); Bailey \& White, 12.1916 (BRI). Darling Downs: Wyberba, Blake 4638, 23.1.1933 (BRI).

NEW SOUTH WALES: North Coast: Clarence River, Wilcox, s.d. (MEL); Woolgoolga, Vickery NSW $8552,1.1 .1935$ (NSW); c. 5 miles [8 km] N. of Wingham, Salasoo 2744, 31.12.1963 (NSW). Central Coast: Morisset, Boorman NSW 8544, 11.1914 (NSW, BRI, MEL, CANB); Silverwater, Lake Macquarie, Jacobs 637, 10.11.1973 (NSW); Awaba, Boorman NSW 8554, 11.1914 (NSW, BRI, AD, CANB); Putty Road, between Colo River \& Howes Valley, Phillips \& Vickery CBG 001266, 20.2.1961 (CBG); Kulnurra, White 0241, 5.12.1935 (NSW); Calga \& Mooney, Goode 261, 27.12.1954 (NSW); Narrabeen, Mair, 20.11.1952 (BRI); Hornsby, Blakely NSW 8549, 4.1914 (NSW); 1-2 miles [1-3 km] W. of Wahroonga, Salasoo 604, 10.12.1950 (NSW); Epping, Johnson NSW 116175, 10.11.1946 (NSW); Cheltenham, Vickery NSW 8551, 4.6.1929, NSW 4772, 23.12.1949 (NSW); Middle Head, Sydney, Bryant 11617, 15.11.1974 (NSW); Lane Cove, Crisp 2409, 13.12.1976 (CBG); Gladesville, Deane NSW 8564, 7.1884 (NSW); Parramatta, Woolls, s.d. (MEL); Long Bay, Hilton, 22.11.1944 (ADW 43952); Rookwood, Cheel NSW 8553, 25.12.1900 (NSW); Kogarah, Camfield NSW 8534, 12.1896 (NSW), Cheel NSW 8555, 28.10.1899 (NSW); Peakhurst, Cheel NSW 8546, 1.1900 (NSW); Hurstville to Tom Uglys Point, Camfield NSW 8535, 1.1.1903 (NSW); National Park, Betche NSW 8542, 11.1889 (NSW), Hilton, 11.1944 (ADW 43953); between Stanwell Park \& Otford, Salasoo 1268, 27,12.1954 (NSW); Casula, Coveny 5354, 30.11 .1974 (NSW); 3 miles [5 km] NW. of Nowra, Rodway NSW 116178, 12.11.1934 (NSW); Nowra North, Constable NSW 16577, 8.12.1950 (NSW). South Coast: Nowra Hill, Rodway NSW 116192, 1.1921 (NSW); 9 miles [14 km] S. of Nowra, Rodway NSW 116176, 1.12 .1929 (NSW); 10 miles [15 km] SW. of Nowra, Rodway NSW $116180,7.2 .1943$ (NSW), Salasoo 3118, 9.1.1966 (NSW); Jervis Bay, Rodway NSW 116177, 12.1919 (NSW); S. of Milton, Hadley NSW 116181, 13.11.1937 (NSW); Wadbilliga Fire Trail, 4 km ENE. of Tuross River, Tindale 4036, Pariss \& Wimbush, 18.1.1975 (NSW). Northern Tablelands: New England, Stuart NSW 8537, s.d. (NSW); Gibralter Range, Jessup \& Gray, 4.12.1953 (CANB 97472); Glen Elgin, Boorman NSW 8539, 12.1913 (NSW); 4.5 miles [8 km] W. of Tingha, Jessup \& Gray, 8.12.1953 (CANB 97460). Central Tablelands: Blue Mountains, Betche NSW 8543, 12.1882 (NSW), Woolls, s.d. (K); Hassans Walls McKie NSW 8561, 12.2.1940 (NSW); Mt Victoria, Cheel NSW 8548, 12.1900 (NSW); Blackheath, Constable NSW 11412, 17.1.1950 (NSW, K); Mt Boyce, Constable 4160, 6.2.1963 (NSW, BRI, CANB); Medlow, Griffith NSW 8545, 10.12.1914 (NSW); Narrow Neck road, Crisp 4002, 12.5.1978 (CBG); Edith Falls, Coveny 4072 \& Bisby, 25.3.1972 (NSW); Woodford, Henderson NSW 116195, 3.1945 (NSW); Lawson, Carne NSW 8541, 3.1912 (NSW); Wentworth Falls, Coveny 40462 \& Bisby, 24.3 .1972 (NSW, CANB); Hill Top, Cheel NSW 8594, 6.1.1912 (NŚW); Fitzroy Falls, Gauba CBG 003943, 71.1953 (MEL). Southern Tablelands: c. 5 miles [8 km] E. of Nerriga, Pullen 2033, 8.12.1959 (CANB):

In the occasional occurences of slightly obtuse ligules $1-1.5 \mathrm{~mm}$ long, and of acute paleas, some specimens of $S$. pubescens approach $S$. pubinodis. However, . the distributions are quite disjunct and the palea of $S$. pubescens is always much shorter than the lemma, whereas in $S$. pubinodis it is equal or subequal. 
Stipa pubinodis Trin. \& Rupr., Mém. Acad. Imp. Sci. Saint-Pétersbourg, ser. 6, Sci., Math., Seconde Pt. Sci. Nat. 5: 50 (1842); Townrow, Pap. \& Proc. Roy. Soc. Tasmania 107: 26 (1974).

HoLOTYPE: 'Tasmania: Hooker' (LE!; isotype K [negative no. Kew 11758]). In K(!) there is a specimen 'Van diemans Land, Gunn no. 588' (also CANB photo 237005) derived from the herbarium of General W.M. Munro. The sheet was annotated by C.E. Hubbard in July 1939, 'Represents the same species as the type of Stipa pubinodis Trin. et Rupr. (V.D.L. 11) in the Leningrad Herbarium'. The specimen accords well with the description provided by Trinius and Ruprecht. Hughes, Kew Bull. 1921: 21 (1921), refers to this specimen under $S$. pubescens $\mathrm{R}$. Br. but notes the more acuminate, hyaline tips of the glumes, and again, on p. 28 , under $S$. pubinodis Trin. et Rupr., which she places amongst 'Species Dubiae vel Excludendae'. There is a further sheet at K - Tasmania, Mt Direction, Gunn, 6.12.1841 - that has been similarly annotated by Hubbard.

SYNONYM: S, pubescens var. semiglabra Reader, Victorian Naturalist 17: 155 (1901). HoLOTYPE: Victoria: 'Dec. 1899. Billabong of Wimmera [River], Lowan, F.M. Reader'. There are two sheets in MEL, 'Banks of 'Billabong', Antwerp, 10.12.1899, F.M. Reader' (MEL 59981) and 'Billabong, Lowan, F.M. Reader 10.12.1899' (MEL 60788); the latter is presumably the Holotype.

Caespitose perennial c. $0.5-1$ metre high, with conspicuously extravaginal shoots from a short rhizome forming a loose tuft of leaves quarter to half the height. Cums erect, slightly compressible, 1-2 mm wide near the base, scarcely ribbed, sparsely pubescent just below the upper nodes with hairs $0.1-0.3 \mathrm{~mm}$ long, glabrous elsewhere; nodes $2-3$, exserted, to $50 \%$ wider than adjacent internodes, densely sericeous with hairs $0.1-0.4 \mathrm{~mm}$ long. Leaf sheaths at first tightly enveloping the culm, later slightly loose, glabrous to scaberulous, 5-10 mm wide, smooth to strongly ribbed on upper sheaths; inner margin glabrous; outer margin ciliate with hairs $0.1-0.4 \mathrm{~mm}$ long to glabrous, especially on the lower sheaths. Ligule coriaceous, 0.6-2 mm long, obtuse, ciliate; auricles absent. Leaf blade tightly rolled, 1-2 $\mathrm{mm}$ wide, to $35 \mathrm{~cm}$ long; abaxial surface smooth to slightly ribbed, glabrous or on the innovations sparsely scabrous; adaxial surface strongly ribbed, densely pubescent with hairs minute- $-0.3 \mathrm{~mm}$ long; margins minutely scabrous. Panicle (11-) $15-25 \mathrm{~cm}$ long, contracted, $1.5-2 \mathrm{~cm}$ wide (excluding awns), exserted, with distant fascicles of unequal, fewflowered, compound branches; axis terete to slightly angular, scabrous with hairs minute- $0.4 \mathrm{~mm}$ long; branches $2.5-4 \mathrm{~cm}$ long, slightly flattened, scabrous with hairs $0.1-0.3 \mathrm{~mm}$ long; pedicels $7-20 \mathrm{~mm}$ long, slightly flattened, scabrous with hairs $0.15-0.3 \mathrm{~mm}$ long. Spikelets $18-26(-29) \mathrm{mm}$ long (excluding awn), gaping widely. Glumes unequal, acute, tip hyaline, nerves heavily overlaid with sclerenchyma, margins ciliate; lower glume 18-26 (-29) $\mathrm{mm}$ long, lower $70-80 \%$ 3 -nerved, scabrous on the nerves with hairs minute- $0.1 \mathrm{~mm}$ long; upper glume 15-20 mm long, lower 30-50\% 5-nerved, the next 50-70\% 4-1-nerved, scabrous with hairs minute- $0.2 \mathrm{~mm}$ long. Floret cylindrical with a slight neck, $10-13 \mathrm{~mm}$ long (including callus). Lemma pale reddish brown at maturity, smooth to finely tuberculate upwards, with sparse white hairs $(0.4) 0.6-0.9(-1.3) \mathrm{mm}$ long on the lower $50-60 \%$, glabrous upwards; lobes absent; coma absent. Callus 2.7-3.5 mm long, \pm straight, the tip weakly bent, with hairs $0.2-1 \mathrm{~mm}$ long, white to slightly fulvous at maturity. Awn 55-95 mm long, with $2(-3)$ bends, c. $0.5 \mathrm{~mm}$ wide near the base; column $30-60 \mathrm{~mm}$ long, $25-40 \mathrm{~mm}$ to the first bend, scabrous with hairs $0.1-0.2 \mathrm{~mm}$ long; bristle scabrous with hairs minute $-0.2 \mathrm{~mm}$ long. Palea \pm equal to the lemma, acute, smooth and glabrous, hyaline on the margins. Lodicules 2, abaxial, membranous, oblong, 1.5-2 mm long. Anthers 4.5-6 mm long, not penicillate. Caryopsis 6-7.5 mm long; embryo c. $30 \%$ the length; hilum equal to the length.

DiSTRIBUTION: Sandstone and sandy areas of Tasmania and southern Victoria, extending into South Australia. 
Selected Specimens: Victoria: Region C: Billabong, Antwerp, Reader, 10.12.1899 (MEL 59975). Region D: Grampians, track from The Sundial to Macheys Peak, Corrick 1624, 28.12.1968 (Corrick herb.); Grampians, S. side of Major Mitchell Plateau, Beauglehole 16530, 10.12.1967 (NSW); c. $3 \mathrm{~km}$ WNW. of Hamilton, Milne 331, 13.11.1979 (NSW). Region E: Hawkesdale, Williamson, 2.5.1899 (MEL 60776). Region J: Moyston, Sullivan, 12.1880 (MEL 60849); 4 km SSE. of Creswick, Beauglehole 61721, 22.11.1979 (NSW). Region N: proposed Warrandyte State Park, Corrick 3722, 3.12.1973 (Corrick herb.); Ringwood, Morrison NSW 150583, 21.10.1891 (NSW); c. 1 mile [1.5 km] SE. of Montrose, Muir 308, 28.12.1957 (MEL); Mt Dandenong, Muir 283, 8.12.1957 (MEL, CANB). Region P: French I., Ramsay, 25.11.1904 (MEL); 10 km NNW. of Anglesea, Beauglehole 63347, 17.1.1979 (NSW). Region R: Mt Buffalo, Blake 7369, 25.1.1935 (BRI). Region S: c. 6 miles [10 km] ENE. of Mallacoota, Beauglehole 31572 \& Willis, 6.11.1969 (NSW).

TASMANIA: Waterhouse Estate, W. of Tomahawk. Townrow 111, 12.1967 (JEST); Devonport, Curtis, 20.2.1948 (BRI); 4 miles [6 km] NW. of St Helens, Goshen rd., Townrow 193, 1.1968 (NSW); 10 miles [15 km] E. of Launceston, Burbidge 2945, 8.1.1949 (CANB); Mathinna, Phillips CBG 001268, 29.1.1962 (CBG); 1.5 miles [2 km] SE. of Pouranna, Townrow 130, 12.1967 (JEST); Pieman River bridge, Davis NSW 116231, 7.1.1937 (NSW); East Coast Highway at Coles Bay turnoff, Townrow 178, 1.1968 (JEST); 3 miles $[5 \mathrm{~km}] \mathrm{N}$. of Triabunna, Townrow 173, 1.1968 (JEST); 5 miles [8 km] E. of Buckland, Townrow 67, 11.1967 (JEST); 3.5 miles [6 km] W. of Runnymede, Townrow 62, 11.1967 (JEST); New Norfolk, Gunn 996, 18.11.1840 (K, NSW 116229); Copping, Blake 18278, 15.1.1949 (BRI, CANB, NSW); Vickery NSW 116226, 15.1.1949 (NSW); W. side of Dunalley bridge, Townrow 102, 12.1967 (JEST); Mt Wellington, Burbidge, 19.1.1949 (CANB 25116); Huon Hwy., c. 10 miles [16 km] S. of Mt Wellington, Vickery NSW 116223, 19.1.1962 (NSW); Mt Nelson, Cleland, 17.1.1928 (AD 96805112, 96805122); Taroona, Townrow 5A, 11.1966 (JEST); nr. Longley, Phillips \& Vickery CBG 001267, NSW 116228, 19.1.1962 (CBG, NSW); Kingston Beach, Rodway NSW 116232, 23.11.1935 (NSW); Eaglehawk Neck, Vickery NSW 8565, 15.1.1949 (NSW); Margate to Snug Plains, Vickery NSW 116224, 21.1.1962 (NSW); South Arm, Townrow 58, 11.1967 (JEST); North Bruny I., Townrow 135, 138, 146, 1.1968 (JEST, NSW); nr. Police Point, Phillips CBG 032260, 25.11.1965 (CBG): nr. Randalls Bay, Phillips CBG 032272, 27.11.1965 (CBG); Channel Hwy. opp. Allonah, Townrow 27, 1.1967 (JEST).

SOUTH AuSTRAL1A: Southern Lofty: Lenswood, Cleland, 16.11.1946 (AD 96324026); Spooner 4330, 6.11.1975, 4372, 16.11.1975 (AD); Mt Lofty Range, Ising, 13.10.1924 (AD 966081490); Swanport, no collector, no. 1555 [?] 12.1855 (MEL 60802). South-eastern: Penola, Tate, s.d. (AD 97742568); Carpenter Rocks, S. end of Lake Bonney (375' S, $\left.140^{\circ} 26^{\prime} \mathrm{E}\right)$, Spooner 5514, 5.11.1977 (AD).

Hooker, Fl. Tasman. 2: 110 (1856), treated S. pubinodis as a synonym of S. pubescens R. Br., as noted by Bentham, Fl. Austral. 7: 570 (1878).

Rodway, Tasman. Fl.: 262 (1903), doubtless placed S. pubinodis (probably together with other species) under $S$. pubescens $\mathrm{R}$. Br.

Townrow, Pap. \& Proc. Roy. Soc. Tasmania 107: 26 (1974), recognized S. pubinodis as the species she had previously (ibid. 104: 81-96 (1970)) misidentified as $S$. pubescens $\mathrm{R}$. Br.

Stipa pycnostachya Benth., Fl. Austral. 7: 568 (1878); Hughes, Kew Bull. 1921: 18 (1921); Gardner, Fl. W. Austral. 1, Gram.: 177 (1952).

Holotype: Western Australia: Int. S.W. Australia, Drummond No. 121, 1849 (K!; isotypes MEL 59978, CANB 237004).

Caespitose perennial to c. 0.6 metres high, with a short rhizome and with conspicuously extravaginal shoots from a third to almost the total height. Culms erect, not compressible, terete, $0.7-2 \mathrm{~mm}$ wide, unribbed, puberulous to pubescent just below the nodes; nodes $2-3$, up to $25 \%$ wider than adjacent internodes, exserted, sericeous. Leaf sheaths tightly enveloping culm; basal sheaths and cataphylls very woolly; upper sheaths puberulous to scaberulous; margins glabrous. Ligule firmly membranous, 3-5 $(-7) \mathrm{mm}$ long (but much shorter in leaves of the basal tuft), acute or laciniate, continuous with sheath margin, glabrous; auricles glabrous. Leaf blade strongly rolled or folded, c. $1 \mathrm{~mm}$ diameter, stiff; abaxial surface unribbed, minutely sparsely scaberulous to 
glabrous and smooth; adaxial surface deeply ribbed, densely pubescent and hirsute; margins glabrous or scabrous. Panicle exserted, short, 6-14 cm long, contracted, c. $1 \mathrm{~cm}$ wide (excluding awns), very dense and spike-like, with very close fascicles of unequal, compound, densely-flowered branches; axis terete, scabrous; branches to $40 \mathrm{~mm}$ long, angular, scaberulous; pedicels $2-7 \mathrm{~mm}$ long, angular, scaberulous. Spikelets $11-15 \mathrm{~mm}$ long (excluding awn), scarcely gaping. Glumes subequal, acuminate, purple at the base, hyaline at the tip, glabrous, scabrous on the nerves; lower glume 11-15 mm long, the lower 30\% 3-nerved; upper glume 10-14 mm long, the lower 25\% 5-nerved, the next 25\% 3-nerved. Floret turbinate, 4-6 mm long (including callus). Lemma granular, brown, with hairs to the apex, the hairs white and slightly spreading at maturity; coma absent; lobes 2, to $0.2 \mathrm{~mm}$ long. Callus straight, $1.3-2 \mathrm{~mm}$ long, with white hairs. Awn $35-50 \mathrm{~mm}$ long, delicate, $0.1-0.2 \mathrm{~mm}$ wide near the base, \pm falcate; column $8-15 \mathrm{~mm}$ long, scaberulous, with hairs to $0.05 \mathrm{~mm}$ long; bristle scaberulous, straight or slightly curved. Palea subequal to the lemma (to $0.3 \mathrm{~mm}$ shorter), acute, with a band of white hairs down the middle. Lodicules 3 , membranous; 2 abaxial $1.0-1.2 \mathrm{~mm}$ long, broadly spathulate; paleal $0.25-0.6 \mathrm{~mm}$ long, acute. Anthers c. $1.5-1.75 \mathrm{~mm}$ long, not penicillate. Caryopsis 2-2.7 mm long; embryo $25-30 \%$ the length; hilum $60-80 \%$ the length.

Distribution: Confined to the south-west of Western Australia in the Coolgardie, Roe, Eyre and Darling districts.

Specimens Examined: Western Australia: Coolgardie: Shire of Oldfield, Orchard 1719,

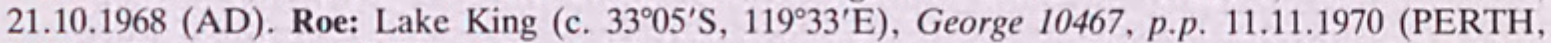
NSW). Eyre: c. 8 km NNW. of Young River crossing, Ravensthorpe-Esperance road, Jackson 1463, 18.10.1968 (PERTH); Desmond nr. Ravensthorpe, Maiden NSW 116842, 11.1909 (NSW, K); $10 \mathrm{~km}$ N. of Needilup, Newbey 4890, 29.10.1975 (PERTH); Fitzgerald River Reserve, Royce 9190, 21.10.1920 (PERTH). Darling: Upper Kalgan, Mueller, 10.1867 (MEL 60774).

A Lake King collection (A.S. George 10467) consists of one plant of $S$. pycnostachya as described, and another plant that differs from typical $S$. pycnostachya in having slightly shorter, broader and denser panicles, in a more cylindrical lemma, and in a thicker column that is pubescent to villous with hairs $0.40-0.75 \mathrm{~mm}$ long. In these characters it is reminiscent of $S$. hemipogon (which also occurs in the area) but differs in the narrow, thick and folded leaves, long ligule, shorter inflorescence, short column hairs and slightly shorter lemma. The atypical specimen from Lake King is intermediate between $S$. pycnostachya and $S$. hemipogon and is of possible hybrid origin despite having fully developed caryopses.

Stipa ramosissima (Trin.) Trin., Mém. Acad. Imp. Sci. St.-Pétersbourg, ser. 6, Sci., Math. 1: 74 (1830); Vickery, Contrib. New South Wales Natl. Herb. 2: 77 (1953); Beadle, Evans \& Carolin, Handb. Vasc. Pl. Sydney Distr.: 532 (1963), Fl. Sydney Region: 657 (1972); Veldkamp, Blumea 22: 10 (1974). Based on Urachne ramosissima Trin., Gram. Unifl.: 173 (1824) (Trinius cites it as Diss 1: 173).

HoLOTYPE: Cited as: 'V sp. e Nov. Holl.' (LE?, not seen). We have been unable to obtain the Type of Urachne ramosissima on loan from LE. There is a specimen at K, 'Sieber Agrostotheca No. $82^{\prime}$, that C.E. Hubbard has compared with the Type of $U$, ramosissima at LE that he regarded as a good match. The only species likely to be confused with $S$. ramosissima is $S$. verticillata; Hubbard, from his determinations of the specimens at $\mathrm{K}$, was well aware of the distinction between these two species. Consequently we are using the Sieber Agrostotheca no. 82 specimen at K as the basis for our concept of this species. 
SynONymS: Stipa micrantha Sieber ex Trin., Mém. Acad. Imp. Sci. St.-Pétersbourg, ser. 6, Sci. Math. 1: 74 (1830); non Cav. 1799. HolotyPE: Cited as 'Sieb. Agrostoth. No. 82 V spp. nov. Holl.' The duplicate at $\mathrm{K}(!)$ is our basis for the application of this name as well as for Urachne ramosissima.

Stipa rugulosa Mez, Feddes Repert. Spec. Nov. Regni Veg. 17: 207 (1921). HolotyPE: Cited as [New South Wales:] 'Blue Mts. Herb. Hort. Sydney' (not seen). The Type is no longer extant at Berlin-Dahlem (B). The description of this reed-like perennial 1.5 metres high with the characters of the glumes, lemma and awn as given by Mez, from the Blue Mountains of New South Wales, leaves no doubt as to the identity of the plant Mez named.

[MISAPPLIED NAMES: Bentham, Fl. Austral. 7: 566 (1878) incorrectly treated S. ramosissima as a synonym of S. micrantha Cav. (=Dichelachne micrantha (Cav.) Domin) and cited specimens of it under that name. F.M. Bailey, Queensland Fl. 6: 1876 (1902), did likewise. Maiden, Manual Grasses N.S.W.: 112 (1898), appears to have identified both $S$. ramosissima and $S$. verticillata as $S$. micrantha Cav. $S$. ramosissima was tentatively regarded as $S$. micrantha Cav. by Hughes, Kew Bull. 1921: 28 (1921).]

Caespitose perennial to c. 2.5 metres high, shortly rhizomatous, without a basal tuft of leaves. Culms erect, with numerous branches at each node, 0.5-7 mm wide near the base, terete, scarcely compressible, weakly ribbed, glabrous; nodes (3-) 6-9, exserted, glabrous, c. $50 \%$ wider than the adjacent internodes. Leaf sheaths at first tightly enveloping the culm, later becoming loose, 3-3.5 mm wide, glabrous; margins glabrous. Ligule membranous, erose, 0.25-0.5 mm long, glabrous; auricles absent. Leaf blade expanded, linear, 1-10 mm wide, 35-40 $(-80) \mathrm{cm}$ long, readily deciduous; both surfaces scabrous, slightly ribbed, margins scabrous. Panicle 8-20 $(-50) \mathrm{cm}$ long, exserted, spreading, 2-4 $(-5.5) \mathrm{cm}$ wide (excluding awns); axis, branches and pedicels terete, scabrous; branches (0.3-) 3.5-5.5 (-10) cm long; pedicels 2-10 mm long. Spikelets 2.3-5 mm long (excluding awn), gaping at maturity. Glumes subequal, acute, erose, inflated, straw-coloured; lower glume 2.3-3.0 (-4.0) mm long, scabrous, lower 95\% 3-nerved; upper glume 2.4-2.8 mm long, glabrous, lower $60 \%$ 3-nerved, the next $40 \%$ 3-2-nerved. Floret broad-cylindrical without a neck, $1.8-2.5 \mathrm{~mm}$ long (including callus). Lemma very dark brown at maturity, tuberculate, glabrous or with few white hairs at the very base; lobes and coma absent. Callus $0.2 \mathrm{~mm}$ long, bent, with white hairs $0.25-0.5 \mathrm{~mm}$ long. Awn (14) 17-30 mm long, strongly once bent, $0.05-0.1 \mathrm{~mm}$ wide near the base, scabrous with minute hairs; column 4-7 mm long; bristle darker than the column. Palea c. $1 / 3$ the length of the lemma, acute, scabrous with minute hairs, margins glabrous. Lodicules 2, abaxial, membranous, $0.3 \mathrm{~mm}$ long, oblong. Anthers $1.0-1.3 \mathrm{~mm}$ long, penicillate. Caryopsis (1.2-) 1.5-1.6 mm long; embryo $25 \%$ the length; hilum $30 \%$ the length.

DISTRIBUTION: Usually in moist, well-drained gullies, near forest or woodland margins in eastern mainland States.

Selected Specimens: Queensland: Burke: Mt Mistake, Simmonds 649, 6.1887 (BRI). North Kennedy: Ravenshoe, Blake 9870, 14.10.1935 (NSW, BRI); near The Crater on Atherton Ravenshoe Road, Webb \& Tracey 6444, 6.12.1962 (BRI). Leichhardt: c. 15 miles [22 km] N. of Wandoan, Johnson 757, 15.4.1949 (BRI); Hillview, 3 miles [5 km] W. of Injune, Johnson 2122, 16.4.1961 (BRI). Port Curtis: Mt Dromedary, Craven 2590, 30.3.1974 (CANB). Burnett: Kingaroy, Smith 3031, 15.4.1947 (BRI, CANB); Taalbinga, White NSW 1/6667, 6.1912 (NSW). Maranoa: 20 miles [32 km] W. of Mitchell, Blake 10954, 31.3.1936 (BRI). Darling Downs: Toowoomba, Maiden NSW 116668, 1.1909 (NSW); Mt Ballow, McPherson Range, Blake 13095, 25.7.1937 (NSW, BRI); Palardo, W. of Miles, Blake 5831, 9.5.1934 (NSW, BRI); near Yarraman, Phillips CBG 001276, 6.6.1961 (CBG); South Durong, Smith, 12.1932 (BRI); Wooroolin, Simmons, 4.1914 (BRI); Bunya Mts, White, 10.1919 (BRI); Mt Mitchell, White, 19.7.1930 (BRI); Laidley Hills, Clemens, 25.1.1944 (BRI); Chinchilla, Beasley, 12.1930 (BRI); Lapunya, 42 miles [66 km] NW. of Goondiwindi, Johnson 515, 27.7.1958 (BRI); Ballandean, Blake 13229, 30.1.1938 (BRI); Forest Reserve 400, a little S. of E. of Warwick, Smith 11472, 12.4.1962 (BRI); Wilsons Peak, Qld/NSW border, Telford 487, 15.5.1969 (CBG); Canungra, White, 5.1917 (BRI); Morans Creek, Robert Plateau, Goy \& Smith 95, 6.1.1938 (BRI). 
New South Wales: Lord Howe Island: Anderson Road, Pickard 1409, 16.9.1970 (NSW). North Coast: Toonumbar S.F., Jones 3377, 12.1966 (CANB); Grafton, Squire NSW 115887, 4.1947 (NSW); Grafton to Dalmorton, Maiden \& Boorman NSW 115901, 11.1903 (NSW); Nymboida River between Grafton \& Dorrigo, Melville 3350, Smith \& Moore, 19.3.1953 (NSW); Brushy Mtn, Maiden NSW 115927, 9.1897 (NSW); Chapmans Plain, c. 15 miles [24 km] NNW. of Dorrigo, Hayes \& McGillivray 2512, 10.1966 (NSW); Thora to Dorrigo, Salasoo 1911, 1.1960 (NSW); top of Dorrigo Mtn., Jessup \& Gray, 17.9.1954 (CANB 97470); Port Macquarie, no collector NSW 115898, 4.1845 (NSW); Dyers crossing via Nabiac, Noonan NSW 115896, 9.1950 (NSW); Allyn River, Boorman NSW 115903, 8.1906 (NSW); Upper Wallis Creek, Brunkerville district, Earp NSW 115900, 7.1953 (NSW). Central Coast: Horse-Shoe Bend, Grose Vale, Carne NSW 115926, 3.1910 (NSW); Eastwood, Johnson NSW 115905, 4.1949 (NSW); Gordon, Blakely NSW 115909, 4.1914 (NSW); Nepean River, Maiden NSW 115916, 9.1906 (NSW); Cabramatta, Woolls NSW 115911, (NSW); Georges River, Casula, McBarron 12546, 6.1966 (NSW); Central Burragorang Valley, Holford NSW 115907, 2.1957 (NSW); Bargo district, Price NSW 115906, 10.1947 (NSW); Rocky Creek, Hill Top, Cheel NSW 115915, 1.1912 (NSW); Lake Illawarra, Carne NSW 115910, 5.1912 (NSW); Broughton Creek on Coolangatta road, Shoalhaven, Rodway NSW I15920, 5.1929 (NSW). South Coast: Yalwal Creek between Yalwal \& Burrier, Rodway NSW 115922, 12.1933 (NSW); Yalwal, c. 15 miles [24 km] WSW. of Nowra, Coveny 3991 \& Bisby, 3.1972 (NSW, CANB); Shoalhaven River, Monaghan NSW 115919, 12.1927 (NSW); Clyde River, Anderson \& Harasymiw 22, 7.12.1976 (CANB 261856). Northern Tableland: Armidale district, Ingram NSW 115892, 12.1939 (NSW). Central Tablelands: Upper Colo River, Vickery NSW 11001, 29.3.1950 (NSW, CANB, K); Kowmung River, Johnson NSW 115893, 3.1951 (NSW); Barbers Creek, Rumsey NSW 115894, 3.1899 (NSW). North Western Slopes: Warrumbungle National Park, Dunlop 539, 21.8.1969 (CBG). Central Western Slopes: Mt Dangar, Gungal, Boorman NSW 115932, 10.1904. North Western Plains: Pallamallawa, Gall NSW 115929, 1916 (NSW); Coolabah, Maiden \& Boorman NSW 115928, 8.1910 (NSW); Boppy Mtn, near Cobar, Boorman NSW 115930, 7.1903 (NSW).

Very similar to $S$. verticillata but often rather more robust and with glabrous lemmas.

Stipa rudis Sprengel, Syst. Veg. Cur. Post 4: 31 (1827); Everett \& Jacobs, Telopea 2(4): 394 (1983).

Holotype: Australia: 'Nov. Holl., Sieber, Agrost. n. 66'. There are two sheets of Sieber no. 66 in MEL (MEL 59980, 59982) and we have used these as our basis for typification. Another sheet of Sieber, Agrost. no. 66, is at K but lacks lemmas.

Mueller (Fragm. 8: $104(1873)$ ) and Bentham (Fl. Austral. 7: 570 (1878)) treated S. rudis as a synonym of $S$. pubescens $\mathrm{R}$. Br. Hughes (Kew Bull. 1921: 21 (1921)) reinstated the name $S$. rudis Sprengel and provided an amended description. However, in addition to the Type (from New South Wales) and a specimen from Victoria (not seen), she cites four specimens from Western Australia that are unlikely to be $S$. rudis Sprengel and may be $S$. eremophila (vel aff.). It appears that her amended description was substantially based on the Western Australian specimens and hence does not apply to $S$. rudis Sprengel (notably in respect of the fulvous hairs of the lemma).

Caespitose perennial to 1.2 metres high with conspicuously extravaginal shoots, often from a short rhizome. Culms usually geniculate near the base, slightly compressible, terete, (1-) 2-4 mm wide near the base, slightly ribbed, mainly glabrous or finely scaberulous, but finely pubescent for varying lengths below the nodes; nodes $2-4$ exserted, to $50 \%$ broader than adjacent internodes, sericeous. Leaf sheaths inflated and falling loose from the culms, slightly ribbed, glabrous to finely and sparsely pubescent, more densely pubescent on the margins just below the orifice, hirsute around the collar; inner margin glabrous; outer margin ciliate just below the orifice of lower sheaths; uppermost sheaths glabrous; cataphylls glabrous, pubescent or shortly villous. Ligule coriaceous, 0.5-2 mm long, ovate to ovate-truncate, slightly laciniate, long- to short-ciliate, abaxial surface pubescent; auricles slightly thickened, with tufts of long to short spreading hairs. Leaf blades to $40 \mathrm{~cm}$ long, $2-5 \mathrm{~mm}$ wide near the base, erect, usually inrolled, the basal leaves more tightly rolled; abaxial surface scarcely 
ribbed or smooth, very densely to sparsely scabrous with minute rigid tubercles or hairs, or almost glabrous; adaxial surface ribbed, densely pubescent or hirsute to sparsely scabrous with minute short hairs; margins similar to abaxial surface. Panicle to $50 \mathrm{~cm}$ long, $1.5-5 \mathrm{~cm}$ wide (excluding awns), exserted or the base concealed, loosely contracted to spreading with distant fascicles of few, fewflowered branches; axis terete, almost glabrous at the base to scabrous upwards; branches to $15 \mathrm{~cm}$ long, terete, scabrous with short to long hairs; pedicels to $15 \mathrm{~mm}$ long, angular, scabrous. Spikelets $8-15 \mathrm{~mm}$ long (excluding awn), gaping. Glumes unequal to subequal, linear to broadly oblong, with nerves heavily overlain with sclerenchyma, pale green to yellow or purple-tinged, glabrous between the nerves, scaberulous over the nerves and the margins often ciliate, or pubescent overall; lower glume 8-15 mm long, the lower $85-90 \% 3-$ nerved, the tip narrowly truncate and firm or broadly obtuse, membranous and erose; upper glume 7-14.5 mm long, the lower 75-90\% 3-nerved or 4-5 nerves present in the lower $25-75 \%$, the tip truncate and firm to membranous, or broadly obtuse, membranous and erose. Floret linear or lanceolate, $5.0-11.5 \mathrm{~mm}$ long (including callus). Lemma brown to purple-brown at maturity, granular at the base, tuberculate upwards, with sparse fulvous to white hairs at the base, thinning to usually glabrous at the apex; coma obscure, of few hairs to $1 \mathrm{~mm}$ long, or absent; 1 lobe $0.05-0.25 \mathrm{~mm}$ long, obtuse, or absent. Callus 0.8-3.2 mm long, gently curved with fulvous to white hairs, darker than those of the lemma. Awn 20-90 mm long, 0.15-0.4 mm wide near the base, gently to strongly twice bent; column 8-45 mm long, $4.5-30 \mathrm{~mm}$ to the first bend, scabrous to pubescent with hairs $0.05-0.3 \mathrm{~mm}$ long; bristle scabrous. Palea $0.5-1.2 \mathrm{~mm}$ shorter than the lemma, acute to broadly acute, granular down the centre with hairs similar to those of the lemma, or almost glabrous; margins firm, smooth and glabrous. Lodicules $2-3$, membranous; 2 abaxial $0.8-1.7 \mathrm{~mm}$ long, oblong to spathulate; paleal acute, c. $1 \mathrm{~mm}$ long, or absent. Anthers $2.0-4.0 \mathrm{~mm}$ long, pencillate. Caryopsis $3-6 \mathrm{~mm}$ long; embryo $20-25 \%$ the length; hilum $70-80 \%$ the length.

\section{Key to the Subspecies}

1. Awn $60-90 \mathrm{~mm}$ long, column $32-45 \mathrm{~mm}$ long; both glumes broadly obtuse with $1-2 \mathrm{~mm}$ of delicately membranous tip, upper glume $11-14.5 \mathrm{~mm}$ long

S. rudis subsp. australis

$1^{*}$. Awn usually $<60 \mathrm{~mm}$ long, occasionally to $65 \mathrm{~mm}$ long, column usually $<25 \mathrm{~mm}$ long, occasionally to $30 \mathrm{~mm}$ long; glumes firm to the tip or, especially the upper, membranous at the very tip

2. Callus $1.5-2.5 \mathrm{~mm}$ long, usually $>20 \%$ the length of the floret (excluding awn); column 20-25 mm long; lower glume narrowly truncate and firm or membranous at the tip, upper glume membranous at the tip, $9-12.5 \mathrm{~mm}$ long .............. S. rudis subsp. rudis

2*. Callus $0.8-1.7 \mathrm{~mm}$ long, usually $<20 \%$ the length of the floret (excluding awn); column $<20 \mathrm{~mm}$ long; glumes narrowly truncate, firm at the tip, the upper glume 7-10 $\mathrm{mm}$ long

S. rudis subsp. nervosa

Stipa rudis subsp. rudis.

SYNONYM: S. nervosa var. neutralis J. Vickery, Contrib. N.S.W. Natl. Herb. 1: 335 (1951). HolotyPE: New South WALES: Katoomba, S.T. Blake NSW 13915, 22.1.1939 (NSW).

Nodes to $50 \%$ broader than internodes. Cataphylls glabrous or pubescent. Leaf blades to $40 \mathrm{~cm}$ long; adaxial surface pubescent to sparsely scabrous with 
minute hairs. Panicle to $40 \mathrm{~cm}$ long, $1.5-4 \mathrm{~cm}$ wide (excluding awns); pedicels to $10 \mathrm{~mm}$ long. Spikelets $10-15 \mathrm{~mm}$ long (excluding awn). Glumes unequal, glabrous with minute scabrous hairs over the nerves, the margins often ciliate; lower glume 10-15 mm long, the lower $90 \%$ 3-nerved, the tip narrowly truncate and firm or membranous; upper glume 9-12.5 mm long, the lower $90 \% 3$ nerved, 4-5-nerved in the lower $25-50 \%$, the tip obtuse and membranous. Floret 7.2-10 mm long (including callus). Coma absent. Callus $1.5-2.5 \mathrm{~mm}$ long. Awn (35-) 40-60 (-65) mm long, $0.15-0.4 \mathrm{~mm}$ wide, gently to strongly twice bent; column $20-25 \mathrm{~mm}$ long, $10-20 \mathrm{~mm}$ to the first bend. Caryopsis $3-3.5 \mathrm{~mm}$ long.

Distribution: On sandstone in higher areas of south-eastern Queensland and eastern New South Wales and Victoria.

Selected Specimens: QueEnSLAND: Darling Downs: Wallangarra, Smith 757, 29.1.1940 (BRI); Wyberba, Blake 4638A, 23.1.1933 (NSW). Moreton: Moggill nr. Brisbane, White 7590, 3.4.1931 (BRI).

New South Wales: Central Coast: Blue Mountains, Calvert, s.d. (MEL 60678); Woodford, Henderson 419, 10.1.1948 (NSW); Pennant Hills, Vickery NSW 26351, 6.12.1953 (NSW); Milperra, Georges River, Vickery, 26.10.1930 (BRI 250632). South Coast: $5 \mathrm{~km}$ NE. of NSW/Vic. border on Princes Hwy, Everett 442 \& Jacobs, 22.10.1981 (NSW); Lyons Road, Currowan State Forest, Pullen 3968, 6.12.1963 (CANB). Northern Tablelands: Yooroonah, McKie NSW 8584, 12.1.1940 (NSW); Glen Elgin, Paltridge 211, 3.12.1931 (CANB). Central Tablelands: Wentworth Falls, Henderson f55, 3.1945 (NSW); Blackheath, Constable NSW 16356, 22.1.1948 (NSW). Southern Tablelands: Crookwell, Hewitt NSW 8566, 9.2.1948 (NSW).

VICTORIA: Region N: 8 miles [13 km] from Anakie Junction towards Ballan, Carroll CBG 024810, 4.1.1966 (CBG); Christmas Hills, Aston 457, 2.12.1959 (MEL, NSW); Heatherdale, Muir 583, 11.12.1958 (MEL). Region P: c. 5 km NW. of Aireys Inlet, Carr \& Adair 7428, 6.1.1977 (NSW). Region T: 4 miles [6 km] SE. of Willow Grove, toward Moe, Carroll CBG 024809, 20.12.1965 (CBG), Region Z: Bidwell, Hunter, 1.1941 (MEL); Warburton, Blake 7219, 19.1.1935 (NSW, BRI); c. 5 miles [8 km] NE. of Mallacoota, Beauglehole 32495 \& Finck, 16.12 .1969 (NSW); 4 miles [6 km] E. of Marlo, Henshall, 3.1.1968 (NT 43327).

See Everett \& Jacobs (loc. cit.) for reasons for recognising this and the other two taxa as subspecies.

Stipa rudis subsp. australis J. Everett \& S.W.L. Jacobs, Telopea 2(4): 396 (1983).

HolotyPe: TASmania: Risdon Vale, J. Vickery NSW 108620, 18.1.1949. Robust coarse grass, spreading panicle. Abundant (NSW).

Cataphylls glabrous or pubescent. Nodes to $40 \%$ broader than internodes. Ligule $0.5-2 \mathrm{~mm}$ long. Leaf blades to $20 \mathrm{~cm}$ long; adaxial surface densely pubescent or hirsute. Panicle to $40 \mathrm{~cm}$ long, 4-5 cm wide (excluding awns); pedicels to $15 \mathrm{~mm}$ long. Spikelets $12-15 \mathrm{~mm}$ long (excluding awn). Glumes subequal, glabrous between the nerves, scaberulous over the nerves, the margins ciliate, or pubescent overall; lower glume 12-15 mm long, the lower $85 \% 3$ nerved, the tip broadly obtuse, membranous and erose; upper glume 11-14.5 mm long, the lower 75-90\% 3-nerved, 4-5-nerved in the lower $50-75 \%$, the tip broadly obtuse, membranous and erose. Floret $8.6-11.5 \mathrm{~mm}$ long (including callus). Coma absent. Lobes absent. Callus 2.0-3.2 mm long. Awn 60-90 mm long, $0.3-0.4 \mathrm{~mm}$ wide, gently to strongly twice bent; column 32-45 mm long, 20-30 $\mathrm{mm}$ to the first bend. Caryopsis c. $6 \mathrm{~mm}$ long.

DISTRIBUTION: Sandstone in higher areas of eastern Victoria, and Tasmania.

Selected Specimens: Victoria: Region E: $22 \mathrm{~km} \mathrm{N.}$ of Nelson, Beauglehole 55344, 6.12 .1976 (NSW, ACB). Region N: Heatherdale, Muir 582, 11.12.1958 (MEL). Region P: Cranbourne, Ross 
2660 \& Corrick, 15.12.1981 (NSW); Frankston, Corrick 6182, 28.11.1978 (NSW). Region S: Healesville, Willis, 27.2.1972 (MEL). Region V: Berrima River, Calvert 23, s.d. (MEL 60677). Region W: $3 \mathrm{~km}$ NE. of Metung, Everett 428 \& Jacobs, 21.10.1981 (NSW). Region Z: Buchan, Verdon 493, 21.11.1970 (CBG); 2.5 miles [4 km] W. of Genoa, Beauglehole 32767, 24.12.1968 (NSW).

TASMANIA: Launceston, Cheel NSW 108621, 1.1928 (NSW); Risdon Vale, Vickery NSW 108620, 18.1.1949 (NSW); Kingston, junction of main road with Lesleyvale Road, Townrow 165, 1.1968 (JEST); 1 mile $[2 \mathrm{~km}]$ W. of Dunalley Bridge, Townrow 103, 1.1967 (JEST); Hobart, Black 290, 8.10.1921 (AD); Mt Wellington, Martin NSW 108622, 3.1933 (NSW); Mathinna, Phillips, 29.1.1962 (NSW 108619, duplicate of CBG 001268); Evandale, beside South Esk Bridge, Townrow 114, 19.12.1967 (UTAS); c. 10 miles [16 km] W. of Copping, Vickery NSW 117311, 15.1.1949 (NSW); 0.5 mile [1 km] E. of O'Connors Peak/Campbelltown road Junction, Townrow 124, 12.1967 (JEST).

Stipa rudis subsp. nervosa (J. Vickery) J. Everett \& S.W.L. Jacobs, Telopea 2(4): 396 (1983). Based on S. nervosa var. nervosa J. Vickery, Contrib. N.S.W. Natl. Herb. 1: 335 (1951).

HoLOTYPE: NEW SOUTH WALES: Central Coast: Epping, W.F. Blakely NSW 8491, 10.1913 (NSW).

Nodes to $25 \%$ broader than internodes. Cataphylls pubescent, shortly villous or glabrous. Ligule $0.5-1.5 \mathrm{~mm}$ long. Leaf blades to $40 \mathrm{~cm}$ long; adaxial surface pubescent to sparsely scabrous with minute hairs. Panicle to $50 \mathrm{~cm}$ long, $1.5-3 \mathrm{~cm}$ wide (excluding awns); pedicels to $10 \mathrm{~mm}$ long. Spikelets $8-12 \mathrm{~mm}$ long (excluding awn). Glumes unequal, glabrous between the nerves, scaberulous over the nerves, the margins often ciliate; lower glume 8-12 mm long, the lower $90 \% 3$-nerved, the tip narrowly truncate and firm; upper glume $7-10 \mathrm{~mm}$ long, the lower $90 \% 3$-nerved or $4-5$-nerved in the lower $50-60 \%$, the tip truncate and firm. Floret 5-7.5 (-8.5) mm long (including callus), with white hairs. Coma usually present but obscure, of few hairs up to $1 \mathrm{~mm}$ long. Callus 0.8-1.7 mm long. Awn 20-45 mm long, 0.15-0.25 mm wide, gently twice bent; column (8-) 11-18 (-20) $\mathrm{mm}$ long, $4.5-11 \mathrm{~mm}$ to the first bend. Caryopsis 3-4.5 $\mathrm{mm}$ long.

DisTRIBUTION: Sandstone in higher areas of south-eastern Queensland, eastern New South Wales and Victoria.

Selected Specimens: Queensland: Darling Downs: between Bald Mountain \& Wyberba, Blake 4522, 16.1.1933 (BRI); Waltangarra, Hilton NSW 11691, 22.12.1944 (NSW, dupl. AD).

NEW SOUTH WALES: Central Coast: Epping, Blakely NSW 8491, 10.1913; Nepean River, c. 4 miles [6 km] S. of Wallacia, Salasoo 2678, 1.12.1963 (NSW). South Coast: Yalwal, Rodway NSW 116189, 2.1.1933 (NSW); Milton, Cambage NSW 8499, 23.12.1908 (NSW); c. $7 \mathrm{~km}$ WNW. of Cobargo, Austin $265,14.4 .1973$ (CANB). Northern Tablelands: 3 miles [ $5 \mathrm{~km}$ ] towards Glencoe from Yarrow Creek, Jessup \& Gray 2622, 6.1954 (CANB); Moredun Creek Dam, McKie NSW 8494, 30.12.1947 (NSW); The Devils Pinch, Armidale to Guyra, McKie WI26, 6.12.1931 (BRI); SW. of Guyra, Youman NSW 116200, 24.12.1931 (NSW). Central Tablelands: 15 miles [24 km] ENE. of Capertee, Vickery NSW 116204, 6.1.1975; Katoomba, Blake 13932, 23.1.1934 (NSW). Southern Tablelands: Conder Creek, A.C.T., Gauba NSW 116187, 11.1.1959 (NSW).

VictoriA: Region R: Little Paradise Falls, c. 27 miles [ $43 \mathrm{~km}]$ SW. of Myrtleford, Beauglehole 43767 \& Cameron, 5.12 .1973 (NSW). Region V: Suggan Buggan, Willis, 16.1.1948 (MEL 1509510), Region W: c. $20 \mathrm{~km}$ NNW. of Omeo, Beauglehole 68689, 19.1.1981 (NSW); Orbost, Prove, 1904 (MEL 60745); Tostaree, Hunter, 12.1951 (MEL 60746); $6 \mathrm{~km}$ NE. of Lakes Entrance, Everett 435 \& Jacobs, 21.10.1981 (NSW); c. 6 miles [9 km] W. Lakes Entrance, Metung road, Muir 1957, Willis, 25.1.1947 (MEL 60718). 
Stipa scabra Lindley in Mitchell, Journ. Trop. Australia: 31 (1848); Bentham, Fl. Austral. 7: 570 (1876), in part; Hughes, Kew Bull. 1921: 18 (1921) in part, ibid. 1922: 17 (1922).

HolotyPE: 'Moora, on the Bogan R., 1846, Mitchell 125' (CGE!). The holotype was collected by Mitchell in New South Wales 'Along the Bogan River'. The specimen label cites 'Moora, on the Bogan R., 1846, Mitchell $125^{\prime}$ and also bears Lindley's handwriting. A specimen at NSW (NSW $116442)$ is a duplicate of the Holotype collection. At $\mathrm{K}$ there is a drawing plus fragments of spikelets identified by D.K. Hughes as Stipa scabra Lindl., which bears the locality ' $32^{\circ} \mathrm{S} 147^{\prime} \mathrm{E}$ ', which is south of Nyngan and close to the Bogan River; the sheet also bears a further attached drawing of the spikelet and lemma with annotations by Hughes and the label 'Mitchell 125, Bogan River' (see CANB photo 237002).

Caespitose perennial to c. 0.5 metres high, without rhizomes, with a basal tuft of fine leaves about half the height. Culms erect or slightly geniculate at the base, terete, 0.6-1.2 (-1.6) $\mathrm{mm}$ wide near the base, \pm compressible, smooth to moderately ribbed upwards, glabrous, scaberulous or pubescent with hairs minute- $-0.1 \mathrm{~mm}$, densely and shortly pubescent just below the nodes; nodes $2-3$ $(-5)$, exserted, glabrous, slightly swollen. Leaf sheaths at first tightly enveloping the culm, later becoming slightly loose, (2.5-) 3.5-5 (-6) mm wide, (smooth-) slightly to moderately (or on the upper sheath strongly) ribbed, glabrous, scabrous or scaberulous or pubescent; inner margin glabrous; outer margin glabrous or ciliate with hairs to $0.2(-0.5) \mathrm{mm}$ long. Ligule truncate, membranous, 0.3-1 (-1.5) $\mathrm{mm}$ long, ciliate with hairs minute- $0.1(-0.3) \mathrm{mm}$ long (upper ligules may be asymmetrical with one lobe to $4 \mathrm{~mm}$ or more long); abaxial surface glabrous; auricles, when present, c. $0.2 \mathrm{~mm}$, glabrous, or with hair tufts to $1 \mathrm{~mm}$ long. Leaf blade folded or inrolled, $0.7-1.5(-2) \mathrm{mm}$ wide, to $25 \mathrm{~cm}$ long; abaxial surface smooth to strongly ribbed, with minute tubercles and/or hairs to $0.15(-0.5) \mathrm{mm}$ long; adaxial surface strongly ribbed, puberulous with hairs minute $(-0.3 \mathrm{~mm})$ long; margins glabrous, scabrous or ciliate. Panicle to $30 \mathrm{~cm}$ long, exserted, with moderately distant fascicles of few to many fewflowered branches, contracted or expanded, $(0.5-)$ 1-2 $(-3) \mathrm{cm}$ wide (excluding awns); axis terete to slightly angular, glabrous or scabrous with hairs minute $(-0.1 \mathrm{~mm})$ long; branches $(0.5-) 1.5-3.5(-7) \mathrm{cm}$ long, angular, scabrous or pubescent along the edge with hairs minute-0.1 (-0.2) $\mathrm{mm}$ long; pedicels $(1.5-)$ $3.5(-8) \mathrm{mm}$ long, angular, scabrous or scaberulous with hairs minute $-0.1 \mathrm{~mm}$ long, sometimes only along the edges. Spikelets (8-) 9-15 mm long (excluding awn), scarcely to moderately gaping at maturity. Glumes unequal, acute to acuminate, glabrous to scabrous upwards; lower glume (8-) 9-10 (-15) mm long, lower (10-) 20-30\% (1-) 3 (-5)-nerved; upper glume (6-) 9-13 mm long, lower (10-) $20-25(-30) \%$ 5-3 (-1)-nerved glabrous to scabrous upwards. Floret narrow-turbinate, without a neck, (4-) 5-6 (-6.5) $\mathrm{mm}$ long (including callus). Lemma smooth to granular upwards, densely sericeous with white hairs $0.2-0.4$ $(-0.6) \mathrm{mm}$ long; lobes (minute-) $0.2-0.25(-0.5) \mathrm{mm}$ long, ciliate with hairs minute- $0.1 \mathrm{~mm}$ long; coma obscure, of few hairs $(0.1-) 0.2-0.4(-0.6) \mathrm{mm}$ long or absent. Callus (1-) 1.4-2 mm long, straight, weakly bent at the tip, densely sericeous with white hairs $0.1-0.5(-0.8) \mathrm{mm}$ long. Awn $30-70 \mathrm{~mm}$ long, falcate, with 2 bends, c. $0.2 \mathrm{~mm}$ wide near the base, straw-coloured to brown; column (5.5-) 8-15 $\mathrm{mm}$ long, (2.5-) 4-7 $\mathrm{mm}$ to the first bend, scabrous with hairs (minute-) $0.1-0.2(-0.3) \mathrm{mm}$ long; bristle scabrous to scaberulous with hairs minute- $0.15 \mathrm{~mm}$ long. Palea (75-) $90-95 \%$ the length of the lemma, obtuse (-acute), often erose, granular along the centre, smooth at the edges, sericeous along the centre back with hairs (0.1-) $0.2-0.3(-0.4) \mathrm{mm}$ long; margins glabrous. Lodicules 2, abaxial, membranous, (0.7-) $1.2 \mathrm{~mm}$ long, oblong. Anthers (0.5-) 1 (-2.5) mm long, penicillate. Caryopsis (2.5-) $3(-4.5) \mathrm{mm}$ long; embryo $20-35 \%$ the length; hilum (55-) $70(-80) \%$ the length. 
The identity and circumscription of $S$. falcata, treated here as $S$. scabra subsp. falcata, have been a source of considerable confusion in Australian herbaria where many other species have been misdetermined under this name, a confusion doubtless initiated by Hughes in her citation (Kew Bull. 1922: 16 (1922)) of a Western Australian specimen with her description, by her citation of three additional specimens that we suspect (but have been unable to verify) may be $S$. scabra Lindl., and by her comments (loc. cit.) under S. variabilis. J.M. Black, Fl. S. Austral. edn 2: 87 (1943), certainly included other species of the Falcatae group under this name, including $S$. nodosa S.T. Blake. It seems certain that Bentham, Fl. Austral. 7: 568 (1878), incorrectly referred specimens of $S$. falcata and other species of the Falcatae group to $S$. setacea $\mathrm{R}$. Br.

Discrimination between $S$. scabra and $S$. falcata is difficult and their distributions overlap. Because of their similarity and the tendency for the distributions to polarize, we feel that it is best to regard $S$. falcata as a subspecies of $S$. scabra. Subspecies scabra reaches its maximum abundance in the predominantly summer rainfall zone of northern New South Wales, extending into Queensland and northern South Australia, but scattered plants may be found over a wider area. Subspecies falcata reaches its maximum abundance in the winter rainfall zones of southern New South Wales, Victoria and southern South Australia, but plants occur as far north as Dubbo and the New England region.

In foliage, appearance of the rootstock, glumes, indumentum and dimensions of the lemma and column, the two subspecies are much alike. In subsp. scabra the ligule is membranous, long (especially in uppermost leaves) and more or less glabrous. The inflorescence is narrow with more or less erect branches and spikelets. In subsp. falcata the membranous ligule is shorter and has few to many erect cilia on the back of the auricular lobe. The inflorescence tends to be rather more spreading with more divergent branches and spikelets.

\section{Key to subspecies}

Inflorescence narrow; ligules (0.3-) 0.6-1 (-1.5) mm long, asymmetrical auricular lobe of

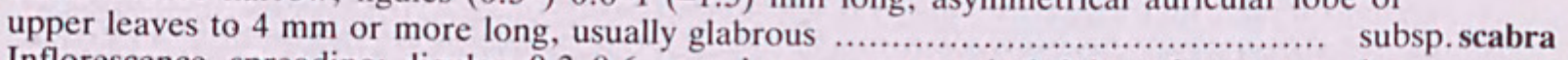
Inflorescence spreading; ligules $0.3-0.6 \mathrm{~mm}$ long, asymmetrical lobe of upper nodes usually $<1 \mathrm{~mm}$ long, usually with a row of hairs subsp. falcata

\section{Stipa scabra subsp. scabra}

Caespitose perennial c. 0.5 metres high. Upper leaf sheaths $2-4 \mathrm{~mm}$ wide. Ligule truncate, membranous, (0.3-) 0.6-1 (-1.5) $\mathrm{mm}$ long, ciliate; auricular lobes on upper culm leaves usually asymmetrical with one lobe to $4 \mathrm{~mm}$ long or more, glabrous. Leaf blades folded or inrolled, $0.6-1.2 \mathrm{~mm}$ wide, to $25 \mathrm{~cm}$ long; abaxial surface smooth to slightly ribbed. Panicle to $30 \mathrm{~cm}$ long, contracted, $1-2 \mathrm{~cm}$ wide. Lower glume (8-) 9-10 (-15) mm long; upper glume (6-) 9-13 mm long. Callus (1-) 1.4-1.7 mm long. Awn 30-70 mm long. Anthers (0.5-) $1(-2.5)$ $\mathrm{mm}$ long; penicillate. Caryopsis (2.5-) $3(-3.5) \mathrm{mm}$ long.

DisTRIBUTION: Widespread through southern Queensland, New South Wales and South Australia; extending into Victoria, Western Australia and Tasmania. 
Selected Specimens: Queensland: Burnett: South Durong, Smith, 12.1932 (BRI). Warrego: Chesterton, Blake 11097, 7.4.1936 (NSW); Gilruth Plains, Mackerras, 11.1939 (CANB 1254). Maranoa: $130 \mathrm{~km}$ SE. of Charleville, Pressland, 11.3.1976 (BRI); Morven, McComb, 4.1918 (BRI); Hodgson, near Roma, Lewington, 11.1933 (BRI); Roma, Blake 10836, 29.3.1936 (BRI); Coolibah, Haywood 1930 (BRI); 60 miles [96 km] W. of St George, Whitehouse, 12.1933 (BRI); 35 miles [56 km] SW. of Eulo, Law 49, 8.1967 (BRI); Cashel Vale, S. of Bollon, Everist 3669, 28.4.1949 (BRI); Nindingully, Allen 641, 21.10.1944 (CANB 10953). Darling Downs: Palardo, W. of Miles, Blake 5832, 9.5.1934 (NSW); Bunya Mts., White, 10.1919 (BRI); Hampton, Scattine, 5.11.1975 (BRI); 2 miles [3 km] S. of Pittsworth, Everist \& Webb 1222, 20.11.1946 (CANB, BRI); Pittsworth, White, 4.2.1930 (K, BRI); 'Kindon' Station, 54 miles [86 km] NNE. of Goondiwindi, Smith 513, 5.12 .1938 (BRI); $20 \mathrm{~km}$ from Warwick on Stanthorpe road, Simon \& Henderson 2511, 9.12.1974, (CANB, BRI, NSW); Warwick, Beckler (MEL 60855); Bybera, White 12223, 3.9.1934 (BRI); 46 km from Inglewood on Warwick road, Simon, Pedley \& McDonald 2861, 3.9.1975 (BRI, NSW); Goondiwindi, Blake 10505, 25.2.1936 (NSW); 30 miles [48 km] from Goondiwindi on Milmerran road, Johnson 505, 12.7.1958 (BRI, CANB); 'Ballandean' Cattle Station, Smith 720, 28.1.1940 (BRI); near Wallangarra, Clemens, 10.1944 (BRI). Moreton: Brisbane, Bailey, 3.1873 (MEL 60853); Mt Cordeaux, Blake 13869, 20.11.1938 (NSW).

NEW SouTH WALES: North Coast: Singleton, Boorman NSW 116407, 11.1914 (NSW, BRI); Rutherford, Hilton, 19.10.1944 (ADW 43981, 43917, 43911, NSW 116441). Central Coast: Concord, Coveny NSW 116419, 7.9.1966 (NSW); Menangle Park, McBarron 16208, 8.1.1969 (NSW); Nepean River, McBarron 12376, 12.4.1966 (NSW). Northern Tablelands: 16 miles [26 km] W. of Guyra, McKie, 2.1.1947 (BRI); Kelso, 30 miles [48 km] NW. of Guyra, McKie NSW 116414, 4.4.1930 (NSW); Dundee, Bellert NSW 116415, 7.2.1966 (NSW); 9.6 miles [15 km] W. of Yarrowyck, Jessup \& Gray 2249, 3.11.1953 (CANB); Chiswick, c. 10 miles [16 km] S. of Armidale, Jessup \& Gray $1711,23.10 .1952$ (CANB); Blue Hole, Davis NSW 116401, 31.4.1949 (NSW); Rimbanda, New England, Jessup \& Gray 2324, 10.11.1953 (CANB); Timor, 15 miles [24 km] E. of Murrurundi, Story 7482, 9.10.1960 (BRI). Central Tablelands: Lucknow, Henderson NSW 116848, 4.1.1948 (NSW); Bathurst, Ingram NSW 116409, 28.2.1942 (NSW); Gap Creek, Mittagong, De Nardi 471, 2.11.1970 (NSW). Southern Tablelands: Lake George, Blake 7560, 3.2.1935 (NSW); Molonglo R., Gauba CBG 00357I, 6.12.1949 (CBG); Lake Burley Griffin, Solling 73, 18.2.1972 (NSW); Canberra, Mair 10, 11.1932 (BRI). North Western Slopes: 30 miles [48 km] S. of Yetman, Jessup \& Gray 1634, 4.10.1952 (CANB); Warialda, Vickery NSW 18447, 1.1932 (NSW); 6 miles [10 km] from Warialda, Moree road, Roe 204, 8.10.1949 (CANB); 10 miles [16 km] W. of Inverell, Hely NSW 116382 , 9.11.1949 (NSW); Inverell, Thomas NSW 116435, 11.1912 (NSW); Pilliga district, Eastburn NSW 116434, 11.1948 (NSW); Razorback Range, Pickard \& Coveny 1125, 4.6.1969 (NSW); Woods Reef, Rupp NSW 116383, 6.1913 (NSW); Barraba, Hay NSW 116396, 9.1903 (NSW); Crow Mt road, Rupp NSW 116413, 4.1914 (NSW); Boggabri, Cambage 2449, 11.1909 (NSW); between Somerton \& Manilla, Hely NSW 116412, 6.11.1949 (NSW); nr. Baradine, Forsyth NSW 116427, 10.1899 (NSW); 7 miles [11 km] E. of Gunnedah, Hely NSW 116375, 29.10.1949 (NSW); Tamworth, Rodway NSW $116420,10.1924$ (NSW); 13 miles [21 km] ENE. of Tambar Springs, De Nardi 180, 29.9.1968 (NSW); Loomberah district, c. 20 miles [32 km] S. of Tamworth, Goode 170, 17.11.1954 (NSW); 10 miles [16 km] NW. of Girilambone, Thompson NSW 116847, 8.9.1959 (NSW); Burrumbuckle Rock. Warrumbungle Range, Crisp 3236 \& Verdon, 4.10.1977 (CBG). Central Western Slopes: 8 miles [13 km] SE. of Murrurundi, Story 6911, 25.11.1959 (CANB, NSW); above Murrurundi railway tunnel, Hunter Valley, Story 6919, 25.11.1959 (CANB, BRI); Wingen, Cambage 2502, 30.10.1909 (NSW); Belltrees via Scone, White NSW 116417, 2.1920 (NSW, BRI); 2 miles [3 km] N. of Burroway, Biddiscombe NSW 116398, 13.3.1954 (NSW); 9 miles [14 km] SE. of Merriwa, Story $6788,8.10 .1959$ (CANB, NSW); Upper Hunter River, Jackson, 4.1913 (CANB 1239); 8 miles [13 km] NE. of Dubbo, Coveny $2479,26.11 .1969$ (NSW); c. 3 miles [5 km] from Dubbo, Phillips CBG 067325, 13.9.1963 (CBG); Dubbo, Vickery NSW 116625, 13.1.1934 (NSW); Gungal, Boorman NSW 116426, 9.1904 (NSW); Denman, Braithwaite NSW 116425, 11.1949 (NSW); Burrendong, nr. Wellington, Herrington NSW 116405, 1950 (NSW); Mudgee, Wollar road, Constable NSW 11493, 5.6.1950 (NSW); Young, Paterson NSW 116432, 12.1917 (NSW); Temora, Dwyer NSW 116623. 11.1915 (NSW). South Western Slopes: Galong. Murphy NSW 116399, 2.1962 (NSW); Wagga Wagga, Wenholz NSW 116424, 1.1913 (NSW). North Western Plains: Bulli Ridge, Collarenebri, Waterhouse NSW 116385, 29.10.1950 (NSW); Collarenebri to Walgett, Vickery NSW 116438, 21.12.1934 (NSW); Burragillo, Merrywinebone, Waterhouse NSW 116403, 2.11.1956 (NSW); Mt Oxley, nr. Bourke, Ingram NSW 116386, 13.7.1958 (NSW); Tarcoon, Keane NSW I16446, 10.1972 (NSW): S, of Coolabah, Jacobs 7, 2.11.1971 (NSW); 29 miles [46 km] NNW. of Wilcannia, De Nardi $255,20.5 .1969$ (NSW); 18 miles [29 km] NW. of Nyngan, Thompson NSW I16846, 8.9.1969 (NSW); Nyngan, Forbes NSW 116411, 21.4.1947 (NSW); Collie to Gilgandra, Vickery NSW 116429, 5.1.1936 (NSW). South Western Plains: 'Bundure' Station, N. of Mt Hope, Martensz 141, 21.5.1969 (NSW); Waranary Hill, W. of Roto, Jacobs 509, 25.10 .1972 (NSW); Condobolin, Kidston NSW $116380,9.1894$ (NSW); $1.5 \mathrm{~km} \mathrm{W.} \mathrm{of} \mathrm{Mt} \mathrm{Binya,} \mathrm{c.} 25 \mathrm{~km} \mathrm{NE}$. of Griffith, Crisp 1424, 12.1.1975 
(CBG, NSW); Griffith, Giltinan NSW 116655, 27.8.1939 (NSW). South Far Western Plains: spur of Manfred Mountain, Fox $8006051,8.6 .1980$ (NSW).

VictoriA: Region D: 8.75 miles [14 km] NNW. of Dergholm, Beauglehole 37950, 25.11.1971 (ACB). Region J: Stawell, Williams 380, 2.1955 (AD). Region M: c. $50 \mathrm{~km} \mathrm{NW.} \mathrm{of} \mathrm{Bendigo,}$ Beauglehole 69411, 23.10.1981 (NSW). Region V: NE. of Bendigo, Beauglehole 33210, Rogers \& Finck, 6.1.1970 (NSW). Region W: Monument Ridge, Beauglehole 37241 \& Rogers, 6.3.1971 (ACB); Jingallala R., Beauglehole 35747, 3.1.1971 (NSW); Devils Backbone, Beauglehole 37270, 8.3.1971 (NSW); between Ensay North \& Ensay South, Beauglehole 37032, 24.2.1971 (NSW); Bairnsdale district, Hart, 20.10.1933 (MEL 60022). Region Z: 8 miles [13 km] from Tubbutt towards McKillops Bridge, Carroll NSW 116439, 17.12.1965 (NSW, CBG); N. of Wulgulmerang, Beauglehole 36151 \& Rogers, 6.1.1971 (NSW).

TASMANIA: 2 miles [3 km] W. of Sorrell-Orielton road along road to Richmond, Townrow 72, 11.1967 (JEST).

Northern TERrITORY: Central Australia, Forde 1575, 1960 (CANB).

SOUTH Australia: North-western: Piltardi, Mann Ranges, Cleland, 21.8.1954 (ADW 44135); Watarunya Rockhole, Mt Lindsay $27^{\circ} 02^{\prime} \mathrm{S}, 129^{\circ} 52^{\prime} \mathrm{E}$, Barker 3076, 31.8.1978 (AD); Everard Ranges, c. $25 \mathrm{~km}$ WSW. of 'Everard Park', Eichler 17527, 15.9.1963 (AD); Cheesman Peak summit, Weber 5316, 28.8.1978 (AD). Flinders Ranges: Mt Lyndhurst, Hilton 1398, 9.4.1955 (ADW); Gammon

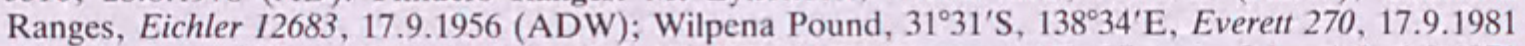
(NSW); Central Chase Range, Crisp 836, 1.9.1974 (AD). Eastern: 'Mt Victor', Crisp 440, 4.9.1971 (AD). Eyre Peninsula: Red Rock, 'Roopena', Cleland, 5.11.1936 (AD 96323285); Iron Knob, Copley 2308, 12.10.1968 (AD); Whyalla West, Hilton 160, 6.9.1952 (ADW). Southern Lofty: Highbury, Kraehenbuehl 823, 22.10.1962 (AD); Manningham, Cleland, 9.1946 (AD 96323269); Encounter Bay, Cleland, 15.8.1940 (AD 95713076).

Western Australia: Giles: NE. of Cavanagh Ranges, George 12164, 26.7.1974 (PERTH). Austin: 154 km from Mt Magnet, Geraldton road, Goodall 2204, 2.11.1963 (PERTH); nr. Hampton Hill, Lipinski 206, 10.1975 (PERTH). Helms: 65 km NE. of Laverton, Beauglehole 59950 \& Erty, 16.9.1978 (NSW).

Stipa scabra subsp. falcata (Hughes) J. Vickery, S.W.L. Jacobs \& J. Everett, comb. et stat. nov.

Basionym: Stipa falcata Hughes, Kew Bull. 1921: 14 (1921).

Holotype: New SOUTH Wales: 'Murrumbidgee, McArthur 141"' (K!), the asterisk indicating its status as Type. 'Murrumbidgee' [River] is a rather indefinite locality name encompassing a wide range of habitats; however, it is known that other plant collections by McArthur from the Murrumbidgee were obtained from the vicinity of Yass, about 1850 (McGillivray, pers. com.).

Caespitose perennial c. 0.5 metres high. Upper leaf sheaths $2.5-4.5 \mathrm{~mm}$ wide. Ligule truncate, membranous, 0.3-0.6 mm long, minutely ciliate; auricular lobes usually less than $1 \mathrm{~mm}$ long with a row of ciliate hairs $(0.1-) 0.5-0.9 \mathrm{~mm}$ long at the base. Leaf blade expanded, folded or inrolled, 0.6-1.2 $\mathrm{mm}$ wide, to $15 \mathrm{~cm}$ long; abaxial surface strongly ribbed. Panicle $10-25 \mathrm{~cm}$ long, usually open, $2-3 \mathrm{~cm}$ wide. Lower glume 10-13 (-15) mm long, upper glume 8-10 (-13) $\mathrm{mm}$ long. Callus $1.5-2 \mathrm{~mm}$ long. Awn $55-65 \mathrm{~mm}$ long. Anthers $2-3 \mathrm{~mm}$ long, \pm penicillate. Caryopsis 3-3.5 mm.

Distribution: Mainly Tableland and southern areas of N.S.W., Victoria and South Australia.

Selected Specimens: QueEnsland: Darling Downs: Stanthorpe, Blake 4412, 12.1.1933 (BRI, NSW).

New South Wales: North Coast: Rutherford Camp, Hilton, 10.1944 (ADW 43910). Central Coast: Homebush, Vickery NSW 116647, 3.11.1929 (NSW); Rookwood, Vickery NSW 116646, 21.9.1930 (NSW). Central Tablelands: Little Bald Hill, c. 4 miles [6 km] N. of Hill End, Pickard 479, 23.10.1969 (NSW); Peel via Bathurst, Constable NSW 16573, 11.10.1950 (NSW); Rydal, Boorman, 12.1900 (NSW). Southern Tablelands: Goulburn, Phillips CBG 001273, 18.4.1961 (CBG); ESE. of Murrumbateman, De Nardi 486, 3.11.1970 (NSW); 8 miles [13 km] SW. of Bungendore, Story 7897, 17.4.1967 (CANB); Black Mountain, Canberra, A.C.T., Pullen 2310, 3.11.1960 (CANB, 
NSW); Mt Ainslie, A.C.T., Gauba CBG 003569, 29.10.1949 (CBG); Mt McDonald, Uriarra area, A.C.T., Pullen 2343, 15.11.1960 (NSW); Uriarra Crossing, Murrumbidgee River, A.C.T., Burbidge 1817, 13.1.1948 (CANB); Kambah Pool, A.C.T., Gauba CBG 046361, 2.12.1954 (CBG, BRI); Tinderry Mountains, Hartley, 21.11.1971 (CANB 243679, NSW); Tumbarumba district, Morland NSW 116642, 4.3.1948 (NSW); on Snowy Mountains Highway near Rhine Falls, Muir 2419, 26.10.1961 (NSW, MEL); Cooma, Mueller NSW 116606, 10.11.1952 (NSW). Central Western Slopes: Dubbo, Boorman NSW 116614, 10.1907 (NSW); 1 mile [1.6 km] E. of Cooyal, Coveny 2461, 9.11.1969 (NSW); South Mudgee, Tindale NSW 116640, 16.10.1953 (NSW); Bowan Park near Cudal, Blakely NSW 116612, 10.1906 (NSW); Cowra, Breakwell NSW 116615, 9.1913 (NSW); Maimura, Robinson NSW 116644, 6.11.1934 (NSW); Young, Maiden NSW 116638, 12.1899 (NSW); Ardlethan, Boorman NSW 116628, 12.1917 (NSW); Temora, Elliot NSW 11660810.1912 (NSW); Wallendbeen, Breakwell NSW 116629, 11.1913 (NSW). South Western Slopes: Demondrille, Cheel NSW 116618, 13.11,1925 (NSW); Cootamundra, per Glenfield Veterinary Research Station NSW $116611,5.10 .1932$ (NSW); S. of Wagga Wagga, Phillips CBG 054399, 18.10.1971 (CBG); The Rock, Phillips CBG 024977, 19,10.1965 (CBG); 4 miles [6 km] E. of Henty, Flynn 63, 6.11.1970 (NSW); Howell Reserve, 4 miles [6 km] W. of Burrumbuttock, McBarron 4733, 3.8.1950 (NSW); Corowa, Moore 474, 5.12.1946 (CANB); Albury, Blake 7416, 27.1.1935 (NSW). South Western Plains: Milewa State Forest, 25 miles [40 km] S. of Deniliquin, Leigh NSW 151532, 3.12.1964 (NSW).

Victoria: Region H: 5 miles [8 km] from Wedderburn towards Inglewood, Phillips CBG 003139 , 31.10.1963 (CBG); Inglewood, Williamson (MEL 60911). Region M: Eaglehawk, Canning 3009, 14.11.1969 (CBG). Region N: Port Phillip, Mueller (CANB 249744). Region R: Warby Range, Canning 4163, 28.12.1976 (CBG); Yarrawonga Road, 6 miles [10 km] north of Wangaratta, Muir 1691, 1.11.1960 (MEL); Mount Pilot Scenic Reserve, c. 8 miles [13 km] N. of Beechworth, Beauglehole 43819 \& Cameron, 8.12.1973 (NSW); Euroa, Meebold 21577, 11.1936 (NSW).

SouTh Australia: Flinders Ranges: Wilpena, Symon 635, 15.9.1960 (ADW); Mt Remarkable National Park, Donner 4907, 6.8.1974 (AD). Eyre Peninsula: Mt Wudinna, Ising, 7.9.1938 (AD 97650093). Northern Lofty: nr. Burra, Field, 10.1894 (AD 95811205); Tothill Range, Kraehenbuehl 1152, 27.10.1963 (AD). Murray: Peebinga, c. $80 \mathrm{~km}$ SSE. of Renmark, Cleland, 14.10.1960 (AD 968061297); 3 miles [5 km] W. of Murray Bridge, Crocker, 23.10.1943 (CANB 12174); c. 5 km S. of Monarto South, Spooner 3120, 21.10.1973 (AD). Southern Lofty: Saddleworth, Symon 788 , 27.10.1960 (ADW); c. $16 \mathrm{~km} \mathrm{~N}$. of Nuriootpa, Kraehenbuehl 1689, 23.10.1966 (AD); Altona via Lyndock, Hilton 188, 22.10.1952 (ADW); Highbury, Smith 720, 1.10.1967 (AD); Waite Institute, Hilton, 20.9.1944 (ADW 43907); Sleeps Hill, Hilton, 20.9.1944 (ADW 43901); Belair, Koch 934, 10.1902 (PERTH); Kinchina, Cleland, 15.10.1955 (AD 95705079); Hackham, Ising, 10.10.1928 (ADW 43914); c. $5 \mathrm{~km} \mathrm{W.} \mathrm{of} \mathrm{Victor} \mathrm{Harbor.} \mathrm{Cleland,} \mathrm{16.8.1940} \mathrm{(AD} \mathrm{95713077);} \mathrm{Encounter} \mathrm{Bay,}$ Cleland, 9.1927 (AD 96324033). Kangaroo Island: nr. Harriet River, Symon, 8.1954 (ADW 4405). South-eastern: Scorpion Spring National Park, c. 15-40 km S. of Pinaroo, Simon 8640, 22.10.1973 (ADW); nr. Narrung, Cleland, 17.11.1953 (AD 96323314); Box Flat, 34 km SSW. of Lameroo, $35^{\circ} 37^{\prime} \mathrm{S}, 14^{\circ} 24^{\prime} \mathrm{E}$, West 2452, 9.10.1977 (AD); Tintinara, Hilton, 12.11.1935 (ADW 43900); c. $10 \mathrm{~km}$ SE. of Naracoorte, Alcock 28, 12.1976 (AD); Big Heath National Park, Alcock 3120, 11.11.1969 (AD); Carpenter Rocks, Spooner 5513, 5.11.1977 (AD)

There are some intermediates between the subspecies that have the inflorescence type of one subspecies but the ligule type of the other. Some examples are:

QUEENSLAND: Goodiwindi, Blake 1050, 25.2.1936 (NSW). NEW SouTH WALES: Warialda, Vickery NSW 18447, 1.1932 (NSW); N. of Gunnedah, Hely NSW 117372, 30.10.1949 (NSW); 'Iolanthe', 26 km W. of Garah, Solling NSW 117374, 21.2.1971 (NSW); Collarenebri, Waterhouse NSW 116385, 29.10.1950 (NSW); Girilambone, Thompson NSW 116847, 8.9.1969 (NSW). VICtORIA: Suggan Buggan, Willis NSW 117373, 16.1.1948 (NSW); Keilor, Meebold 21812, 12.1936 (NSW). SouTH AuSTRaLiA: Sandergrove, Menzel NSW 117375, 10.1896 (NSW).

Stipa semibarbata $R$. Br., Prodr.: 174 (1910); Hook. f., Fl. Tasman. 2: 110 (1860), in part; Kunth, Enum. Pl. 1: 183 (1833); Bentham, Fl. Austral. 7: 568 (1878), in part but excluding at least the N.S.W. citations; Hughes, Kew Bull. 1921: 20 (1921), at least as to the Tasmanian citations; Rodway, Tasmanian Fl.: 262 (1903); Black, Fl. S. Austral. 1: 66 (1922), probably only in part, edn 2: 89, fig. 109 (1943); Gardner, Fl. W. Austral. 1, Gram.: 179 (1952), probably only in part. 


\section{Holotype: TASmania: Port Dalrymple, R. Brown 6204 (BM!)}

Caespitose perennial to c. 1 metre high, not rhizomatous, with a basal tuft of leaves to about half the height. Culms erect or geniculate at the base, terete, 1-3 mm wide near the base, not compressible, smooth, pubescent to scaberulous or glabrous upwards but pubescent near the nodes; nodes 2-3, exserted, sericeous with hairs $0.3-0.5 \mathrm{~mm}$ long, $25-50 \%$ wider than the adjacent internodes. Leaf sheaths at first tightly enveloping the culm, later becoming slightly free, $5-10 \mathrm{~mm}$ wide, slightly to strongly ribbed, minutely pubescent to glabrous or scaberulous with minute tubercles; inner margin glabrous; outer margin ciliate with hairs minute- $0.7 \mathrm{~mm}$ long to glabrous; collar ciliate with hairs (0.2-) $0.5-0.8 \mathrm{~mm}$ long. Ligule truncate, coriaceous, $1-1.5 \mathrm{~mm}$ long, ciliate with hairs $0.2-0.5 \mathrm{~mm}$ long; abaxial surface sericeous with hairs c. $0.5 \mathrm{~mm}$ long; auricles thickened, $0.5-1 \mathrm{~mm}$ long. Leaf blade loosely rolled, $1-3(-7) \mathrm{mm}$ wide, to $30 \mathrm{~cm}$ long; abaxial surface moderately ribbed, slightly scabrous with minute tubercles, to glabrous; adaxial surface strongly ribbed, pubescent with hairs minute- $0.2(-0.5) \mathrm{mm}$ long; margins glabrous to scaberulous. Panicle $5-30 \mathrm{~cm}$ long, exserted, with moderately distant fascicles of unequal, few- to manyflowered, compound branches, contracted, $2-4 \mathrm{~cm}$ wide (excluding awns); axis, branches and pedicels terete, scabrous or pubescent with hairs minute- $0.6 \mathrm{~mm}$ long; branches 2-6 cm long; pedicels 5-15 mm long. Spikelets 20-25 mm (excluding awn), gaping. Glumes unequal, acuminate, straw-coloured, hyaline at the edges, scabrous with hairs to $0.1 \mathrm{~mm}$ long along the nerves, scaberulous between the nerves; lower glume 18-25 (-27) mm long, lower 60-75\% 3-nerved, upper 25-40\% 2-nerved, upper glume 15-25 mm long, lower 20-45\% 5-7nerved, upper $55-80 \%$ 6-nerved. Floret cylindrical without a neck, 9-11.5 mm long (including callus). Lemma almost black at maturity, the surface smooth to granular upwards, sericeous with white hairs $0.6-0.8 \mathrm{~mm}$ long; coma absent; lobes absent. Callus $3-3.5 \mathrm{~mm}$ long, weakly bent at the tip, densely sericeous with white hairs $0.2-1 \mathrm{~mm}$ long. Awn $70-110 \mathrm{~mm}$ long, twice bent, c. $0.5 \mathrm{~mm}$ wide near the base; column $30-40 \mathrm{~mm}$ long, $20-30 \mathrm{~mm}$ to the first bend, brown, pubescent with hairs $0.3-1 \mathrm{~mm}$ long; bristle brown, scabrous with hairs $0.1 \mathrm{~mm}$ long. Palea \pm equal to the lemma, acute, granular down the centre, smooth on the edges, sericeous down the centre with hairs $0.4-0.7 \mathrm{~mm}$ long. Lodicules $3 ; 2$ abaxial membranous, $1.5-2.5 \mathrm{~mm}$ long, obtuse; paleal membranous, c. $0.7 \mathrm{~mm}$ long, obtuse. Anthers 3.5-5 mm long, \pm penicillate. Caryopsis 5.5-6.5 mm long; embryo $20 \%$ the length; hilum $90 \%$ the length.

\footnotetext{
Distribution: Widespread in Victoria, Tasmania and South Australia, extending into southern Western Australia.
}

Selected Specimens: New South Wales: Southern Tablelands: nr. Delegate, Phillips CBG $018003,14.11 .1961$ (CBG).

Victoria: Region C: 35 miles [56 km] SW. of Horsham, Beauglehole 30958, 25.9.1969 (NSW). Region D: on Coleraine railway line, c. $3 \mathrm{~km}$ WNW. of Hamilton, Milne 331, (MEL); Wannon, Corrick 1560, 8.12.1968 (Corrick herb.). Region H: Campbells Creek, Mason, 12.1886 (MEL 59991). Region J: Ararat, Beauglehole 21726, 15.11.1966 (NSW); Ben Major State Forest, Farrington 2, 17.12.1963 (MEL 59993). Region M: 7 miles [11 km] S. of Axedale, Young, spring 1974 (MEL 1509524). Region N: Studley Park, Melbourne, Melville 2081, Willis \& Chattaway, 20.11.1952 (MEL); Port Phillip, Luehmann NSW 116472 (NSW). Region P: Frankston, 145'10'E, 38 $10^{\circ}$ 'S, Corrick 6192, 28.11.1978 (MEL). Region W: c. 6 miles [10 km] W. of Lakes Entrance on the Metung rd., Muir 1956, 27.11.1960 (NSW).

TASmania: 1 mile [1.6 km] NW. of St Helens, Goshen road, Townrow 190, 19.1.1968 (JEST); 1 mile [1.6 km] S. of Scamander, Townrow 185, 1.1968 (JEST); 10 miles [16 km] N. of Orford, Townrow 175, 1.1968 (JEST); New Norfolk, Gunn 996, 15.11.1840 (NSW); 1 mile [1.6 km] W. of Sorrel on Orielton road, Townrow 59, 11.1967 (JEST); Risdon, Burbidge 3184, 18.1.1949 (CANB); 
Hobart, Lucas NSW 116468, 12.1923 (NSW); Mt Wellington, Martin NSW 116471, 3.1933 (NSW); North Bruny I., Townrow 134, 1.1968 (JEST).

South Australia: Eyre Peninsula: Marble Range, Weber 6025, 30.9.1979 (AD). Murray: Braendlers Scrub, $139^{\circ} 07^{\prime}$ E, 35 $15^{\circ} 1{ }^{\prime}$ S, Spooner 4324, 2.11.1975 (AD); Monarto, Spooner 4303, 25.10.1975 (AD). Yorke Peninsula: Hundred of Ramsay, Blaylock 1610,10.10.1970 (AD). Southern Lofty: c. $8 \mathrm{~km}$ E. of Tanunda, $34^{\circ} 32^{\prime} \mathrm{S}, 138^{\circ} 58^{\prime} \mathrm{E}$, Kraehenbuehl 2853, 29.10.1978 (AD); Mt

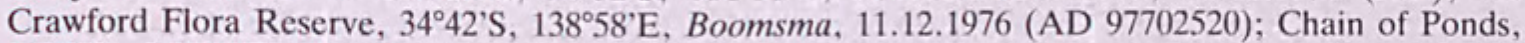
$34^{\circ} 49^{\prime}$ S, $138^{\circ} 48^{\prime} \mathrm{E}$, Penning 102, 27.11.1976 (AD); Torrens Gorge West, Spooner 530, 8.10.1969 (AD); nr. Tea Tree Gully Quarry, $34^{\circ} 50^{\prime} \mathrm{S}, 138^{\circ} 44^{\prime} \mathrm{E}$, Penning $21,13.10 .1975$ (AD); c. $12 \mathrm{~km}$ ENE. of Adelaide, Whibley 2801, 21.11.1968 (AD); Morialta Conservation Park, Clarke 19, 11.11.1977 (AD); c. $6 \mathrm{~km} \mathrm{E}$. of Adelaide, Smith 1999, 27.10.1970 (AD); Stonyfell, Preiss 122, 14.10.1972 (AD); between Basket Range \& Uraidla, Cleland, 20.11.1943 (AD 98140420); Glenelg Golf Course, Smith 552, 3.10.1967 (AD); Loftian Park, Adelaide Hills, Hilton, 26.10.1953 (ADW 43956); Mt Lofty, Ising, 7.10.1924 (AD 97421225); nr. Blackwood, Black, 20.10.1913 (AD 97420208); Belair, Koch NSW 15066, 8.1902 (PERTH); 2 miles [3 km] S. of Mt Barker, Crisp 4711, 24.12.1978 (CBG); Hardys Scrub, McLaren Vale, Boomsma, 30.11.1978 (AD 97911351); 2 km S. of Meadows, Czornij 55, 27.10.1966 (AD); Kuitpo, Cleland, 3.1932 (AD 97421225); Mt Moon, Nangkita, Tindale 7.11.1941 (AD 97739142); Myponga, Whibley 442. 10.12.1958 (AD); Finiss Scrub, Spooner 962, 18.11.1970 (AD); Fleurieu Peninsula, Cleland, 11.11.1967 (AD 93315073). South-eastern: Lake Albert, on Coorong, Cleland, 8.11.1958 (AD 96806198).

Western Australia: Darling: Midland Junction, Roe, 20.10.1934 (CANB 1248); Glen Forrest, Aplin 1034, 10.10.1961 (PERTH); Lake Banganup, Weston 9790, 2.11.1974 (PERTH); Hamel, Blake 18043, 31.8.1947 (PERTH); Harvey to Waroona, Aplin 1196, 30.10.1961 (PERTH); Harvey, Gardner, 10.1931 (PERTH); Boyanup, Carne, 27.11.1923 (PERTH); 12 miles [19 km] NE. of Busselton, Beauglehole 12449, 6.9.1965 (NSW, PERTH); Augusta, Galbraith, 28.9.1965 (MEL 59936); between Augusta \& Nannup, Phillips CBG 027108, 18.10.1962 (CBG); Big Brook, Pemberton, Hart 33, 14.11.1962 (PERTH); Mt Barker, Hay, 12.1924 (PERTH); 3 miles [4 km] W. of Mt Barker, Fairall 2238, 5.10.1967 (PERTH).

$S$. semibarbata has been confused with $S$. mollis, $S$. densiflora and $S$. hemipogon, and references to $S$. semibarbata may be to any of the above species.

Stipa setacea R. Br., Prodr.: 174 (1810); Bentham, Fl. Austral. 1: 568 (1878), in part; Vickery, Contrib. New South Wales Natl. Herb. 2: 78 (1953); Beadle, Evans \& Carolin, Handb. Vasc. Pl. Sydney Dist.: 532 (1963), Fl. Sydney Region: 656 (1972); Hughes, Kew Bull. 1921: 25 (1921).

LECTOTYPE, here designated: NEW SOUTH WALES: Port Jackson, $R$. Brown, 1802-1805 (BM!). Brown cites regions $\mathrm{J}$ and $\mathrm{D}$ (i.e. Port Jackson and Tasmania) in the protologue. Townrow (Pap. \& Proc. Roy. Soc. Tasmania 104: 85 (1970)) suggests that $S$. setacea does not occur in Tasmania and we have seen no specimens from that State. We therefore here designate the Port Jackson specimen as Lectotype. The plant described and figured as $S$, setacea by Hooker (Fl. Tasman. 2: 110, pl. 157 (1860)) with 'a silky, short, membranous ligule' is a different species not in accord with Brown's description of $S$. setacea.

Synonyms: Dichelachne setacea (R. Br.) Nees in Lehmann, PI. Preiss. 2: 98 (1846). Typification: Nees cites Stipa setacea $\mathrm{R}$. Br. as the basionym. Nees also cites the collection Preiss 1854. Veldkamp (Blumea 22: $11(1974)$ ) considers a specimen of Preiss 1854 at BM to be the Holotype of D. setacea Nees and identifies it as Stipa stipoides (Hook. f.) Veldk. We have not been able to locate the specimen at BM, but a specimen of Preiss 1854 at MEL is not $S$. stipoides, differing in the shorter glumes and lemmas, but is entirely consistent with $S$. juncifolia Hughes (see notes under $S$. stipoides).

S. setacea var. latiglumis J. Black, Trans. \& Proc. Roy. Soc. S. Austral. 46: 565 (1922), Fl. S. Austral. 1: 65 (1922). LECTOTYPE, here designated: In AD there are three syntypes from Black's herbarium mounted together on one sheet, from Belair, Minnipa and Telowie Gorge (see also CANB photo 237003). The specimen from Minnipa bears a single very long inflorescence scarcely emerging from the sheath. The specimen from Belair bears one panicle, and that from Telowie Gorge two panicles, all in an old condition with the glumes expanded. We here designate the Telowie Gorge specimen as Lectotype. We can find no justification for maintaining var. latiglumis. 
The glumes of $S$. setacea are hyaline and long-acute when complete but they are susceptible to damage. When the glumes are damaged at the apex they expand and flatten, causing the appearance that caused Black to name the variety. Repeated sorting has revealed no characters correlated with this appearance.

Stipa brachystephana S. T. Blake, Proc. Roy. Soc. Queensland 62: 90, pl. 6 (1952). HolOTYPE: South Australia: Flinders Ranges: Port Germein Pass, S.T. Blake 16858, 29.8.1946 (BRI!; isotype ADW). In this specimen, though the spikelets are well developed, they are still relatively young and the glumes appear firmer than they do in more mature specimens.

Caespitose perennial to c. 0.8 metres high, with a basal tuft of leaves to about half the height, without rhizomes. Culms erect or geniculate at the base, terete, c. $1 \mathrm{~mm}$ wide near the base, \pm compressible, moderately to slightly ribbed, glabrous to puberulous, sometimes scaberulous upwards; nodes 2-4, exserted, glabrous, if swollen then to $50 \%$ wider than the adjacent internodes. Leaf sheaths tight around the culm, 3-7 mm wide, strongly to slightly ribbed, glabrous to scaberulous; margins glabrous. Ligule obtuse, membranous, 2-9 mm long, not ciliate; abaxial surface glabrous to sparsely puberulous; auricles mostly on lower leaves, thickened, c. $1 \mathrm{~mm}$ long, glabrous. Leaf blade firmly folded to inrolled, $0.5-1.5 \mathrm{~mm}$ wide, linear, to $30 \mathrm{~cm}$ long; abaxial surface strongly ribbed on innovations, smooth to moderately ribbed elsewhere, glabrous to scabrous with minute tubercles; adaxial surface strongly ribbed, densely pubescent with hairs minute- $0.1 \mathrm{~mm}$ long; margins glabrous to scabrous with minute tubercles. Panicle 10-20 cm long, exserted, with distant fascicles of unequal, few-flowered branches, contracted, $1.5-3 \mathrm{~cm}$ wide (excluding awns); axis, branches and pedicels scabrous along the edges with hairs minute $-0.1 \mathrm{~mm}$ long; branches $1.5-4.5 \mathrm{~cm}$ long; pedicels $1.5-7.5 \mathrm{~mm}$ long. Spikelets 9-15 (-16) $\mathrm{mm}$ long (excluding awn), gaping at maturity. Glumes unequal, acuminate, strawcoloured, hyaline and often erose at the tip, margins glabrous; lower glume glabrous to scaberulous at the tip, 9-15 (-16) mm long, lower 15-50\% 3-nerved; upper glume glabrous to scaberulous at the tip, 7-10 mm long, lower $30-50 \% 5-$ nerved, upper 50-70\% (3-)1-nerved. Floret turbinate with a neck, slightly gibbous, with the awn eccentric, 5.5-7 mm long (including callus). Lemma black at maturity, the surface scaberulous with minute tubercles, not convolute, the margins tightly incurved into a groove down the palea, densely sericeous with white hairs $0.4-0.8 \mathrm{~mm}$ long; lobes absent; coma obscure, to $0.8 \mathrm{~mm}$ long. Callus $1.7-2.5 \mathrm{~mm}$ long, straight, weakly bent at the tip, densely sericeous with white hairs $0.1-1 \mathrm{~mm}$ long. Awn $25-40 \mathrm{~mm}$ long, twice bent, $0.3-0.5 \mathrm{~mm}$ wide near the base; column $10-15 \mathrm{~mm}$ long, $5-8 \mathrm{~mm}$ to the first bend, dark brown, scabrous with hairs minute- $0.1 \mathrm{~mm}$ long; bristle paler than the column, scaberulous. Palea subequal to the lemma, obtuse to acuminate, smooth, deeply grooved down the adaxial surface, glabrous to sericeous in the groove with hairs minute $-0.5 \mathrm{~mm}$ long, margins glabrous. Lodicules $3 ; 2$ abaxial membranous, $0.5-1.5 \mathrm{~mm}$ long, oblong to acute; paleal membranous, $0.4-0.8 \mathrm{~mm}$ long, oblong. Anthers 2.1-2.3 mm long, not penicillate. Caryopsis $2.5-3 \mathrm{~mm}$ long; embryo $20-40 \%$ the length; hilum $70-80 \%$ the length along the centre of the wide groove corresponding to the groove on the palea.

DISTRIBUTION: Widespread but not common in southern Queensland, New South Wales, southern Victoria and southern South Australia.

Selected SPeCimenS: QueEnSLAND: Maranoa: 20 miles [32 km] W. of Mitchell, Blake I0953, 31.3.1936 (NSW); nr. Amby, Smith 6307, 22.5.1955 (BRI); Chinchilla, Beasley 156, 4.1931 (BRI). Darling Downs: nr. Meandarra, Blake 13277, 13.2.1938 (BRI); Killawarra, Moonie River, Everist 1792, 30.4.1939 (BRI); between Inglewood \& Milmerran, White, 20.1.1934 (BRI, K); Inglewood, Wicks, 11.1933 (BRI, K); Kingsford Ridge, Hermitage Research Station, Simon \& Henderson 2500, 9.12.1974 (BRI); nr. Wyberba, Blake 4641, 23.1.1933 (BRI); Bald Mt, nr. Wallangarra, Blake 448I, 14.1.1933 (BRI). 
New South Wales: North Coast: Maitland, Hilton, 10.1944 (ADW 43968); Rutherford Camp, 1 mile [1.6 km] from West Maitland, Hilton, 9.1944 (ADW 43969). Central Coast: Hillview, 3 miles [5 km] SW. of Liverpool, Coveny NSW 116039, 19.3.1967 (NSW); Glenfield, McBarron 13699, 14.2.1966 (NSW, BRI, CANB, MEL); Cobbitty, Vickery NSW 116038, 6.10.1930 (NSW); Camden, Price NSW 1876, 7.1946 (NSW); Picton. McBarron 10087, 6.12.1964 (NSW). Northern Tablelands: New England, Stuart, s.d. (MEL); Green Valley, via Guyra, no collector, 21.12.1934 (NSW 116036); Crow Mountain, E. of Barraba, Williams NSW 127933, 21.12.1972 (NSW). Central Tablelands: 2 miles [3 km] N. of Burrawang, Biddiscombe NSW 116030, 13.4.1954 (NSW). North Western Slopes: Warialda district, no collector, 5.12.1952 (NSW 116031); Gunnedah, Bridge NSW I16028, 2.11.1956 (NSW); Warrumbungle National Park, Dunlop 636, 21.8.1969 (CBG); Binnaway, Little NSW 116033, 12.1950 (NSW). Central Western Slopes: 8 miles [13 km] SW. of Cassilis, Story 7025, 5.12.1959 (CANB); Trangie, Hutchins, 3.1947 (CANB 13229, K); Gulgong, Williardt NSW 116048, 23.11.1956 (NSW); Forbes, Crosby NSW 116032, 16.7.1952 (NSW). South Western Slopes: Wagga, Newman NSW 116042, 1955 (NSW); Howlong, McBarron 2602, 19.11.1948 (NSW). North Western Plains: Coolabah, Cunningham NSW 116041, 15.7.1968 (NSW); Cobar Reserve, 5 miles [8 km] N. of Cobar, Dumbleton NSW 116040, 15.6.1969 (NSW); Boppy Mt, nr. Cobar, Boorman NSW 116035, 7.1903 (NSW); Mt Grenfell, Cobar, Cunningham \& Milthorpe 2916, 26.10.1974 (NSW). South Western Plains: Mt Binya, c. 25 km ENE. of Griffith, Crisp 1476, 12.11.1975 (CBG, NSW).

VictoriA: Region C: Mt Arapiles, Beauglehole 7446 (in part), 23.11.1964 (NSW), 29689, 21.11.1968 (NSW). Region M: c. $50 \mathrm{~km} \mathrm{NW.} \mathrm{of} \mathrm{Bendigo,} \mathrm{Beauglehole} \mathrm{69435,} \mathrm{24.10.1981} \mathrm{(NSW),}$ Region N: 3.5 miles [6 km] N. of Sunbury, Pitt 17.1.1974 (MEL).

South Australia: Flinders Ranges: Oraparinna National Park, Symon 7570, 8.10.1971 (ADW); Mt Brown, Cooper, 21.9.1954 (AD 968020459); Melrose, Hilton, 12.9.1951 (ADW 44047); Gammon Range (30⒉'S, $\left.139^{\circ} 05^{\prime} \mathrm{E}\right)$ Williams $11634,30.10 .1980$ (AD). Northern Lofty: Upper Telowie Gorge, Spooner 6613, 7.10.1979 (NSW); Tothill Range, Kraehenbuehl 1083, 27.10.1963 (AD). Murray: Kinchina, Cleland, (AD 97420190). Southern Lofty: Anstey Hill, Cleland, 14.9.1946 (AD 96324083); Hope Valley, nr. reservoir, Spooner 1517, 9.9.1971 (AD); Torrens Gorge West, Spooner 535, 537, 4.10.1969 (AD); Highbury, Smith 1975, 13.10.1969 (AD); c. $11 \mathrm{~km}$ NE. of Adelaide, Spooner 324, 27.9.1968 (AD); Holden Hill, Spooner 2749, 2.3.1973 (AD); Stonyfell Hills, Cleland, 21.9.1952 (AD 95705073); Mitcham, Harris 30, 26.9.1959 (AD); Eden Hills, Purdie 92, 11.9.1966 (AD); Belair, Cleland, 20.10.1935 (AD 96324081, 96324084); $42 \mathrm{~km} \mathrm{SE}$. of Adelaide $\left(35^{\circ} 12^{\prime} \mathrm{S}, 1^{\circ} 9^{\circ} 00^{\prime} \mathrm{E}\right)$, Williams 189, 13.10.1952 (AD); Finniss River, Black, 10.1929 (AD 97420190); Halls Creek, Cleland 16.11.1930 (AD 98110407), 5.1.1940 (AD 96324082); Encounter Bay, Cleland 1.1924 (AD 96324080, 97420192). South-eastern: Bordertown, Black 25.11.1917 (AD 97420190).

S. setacea appears to be closely related to species of the genus Piptochaetium and resembles them in having: (i) the palea grooved on the adaxial surfacebetween the two nerves (Fig. 4d); (ii) the floret \pm turbinate and slightly gibbous high up on the back; and (iii) the sulcate fruit with insertion of stigmas at one side of the obtuse to truncate apex, above the furrow.

We are retaining $S$. setacea (and the closely related $S$. feresetacea) in Stipa because of: (i) the membranous palea (rigid, crustaceous or coriaceous in Piptochaetium); (ii) the fully enclosed palea tip (exposed and projecting in Piptochaetium); and (iii) the lack of a corona (usually present in Piptochaetium).

The grooved back of the palea is also developed to a much lesser degree in $S$. juncifolia, $S$. petraea and $S$. stipoides, none of which possesses any other features of Piptochaetium, and also in S. gibbosa, which has as well, a turbinate, gibbous floret and a projecting palea tip.

On balance, the morphological characters appear slightly to favour the retention of $S$. setacea and S. feresetacea in Stipa. Biogeographic arguments would also favour the retention of these two species in Stipa. Species of Piptochaetium s. str. are otherwise confined to the American Continent. 
Stipa stipoides (Hook. f.) Veldkamp, Blumea 22: 11 (1974); Townrow, Pap. \& Proc. Roy. Soc. Tasmania 112: 261 (1978). Based on Dichelachne stipoides Hook. f., Fl. Nov.-Zel. 1: 294, t. 66 (December 1853).

Lectotype (Townrow 1978): New Zealand: Bay of Islands, Hooker (K!). Veldkamp (ibid.) cites a Banks and Solander specimen from Mercury Bay and Bay of Islands (BM) as the Holotype. Townrow (ibid.) stated that, as Hooker's citation included three specimens, the selection of a lectotype was required and, following the recommendations of the Code, the most appropriate specimen was the Hooker specimen from the Bay of Islands (K). We have followed her lectotypification.

SYNONYM: S. teretifolia Steudel, Syn. Pl. Glum. 1: 128 (March 1854); Bentham, Fl. Austral. 7: 567 (1878); Rodway, Tasman. Fl.: 262 (1903); Hughes, Kew Bull. 1921: 12 (1921); Black, Fl. S. Austral. 1: 65 (1922), edn 2: 86 (1943); Willis, Handb. PI. Victoria 1: 182 (1962), edn 2, 1: 182 (1970). HolotyPE: cited in the protologue as 'Legit Urville ad Western Port' (Victoria). The Holotype from the Steudel Herbarium (P!) bears a ticket annotated 'Stipa teretifolia Steudel! Port Western (Australia) 9bre 1826. Chauvin 49.' We are therefore unable to understand why Veldkamp (ibid.) has cited the Holotype as being: 'Lesson s.n. (P)' which can surely not be the same specimen.

Caespitose perennial to c. 1.2 metres high with an erect basal tuft of pungenttipped leaves. Culms erect, $0.6-1 \mathrm{~mm}$ wide near the base, \pm compressible, smooth and shiny; nodes c. 3 , not exserted. Leaf sheaths \pm inflated at the base, the upper sheaths not inflated, weakly ribbed, glabrous to shortly pubescent between the nerves with hairs $0.05-1 \mathrm{~mm}$ long; margins glabrous, lower sheaths 4-10 mm wide, upper sheaths $2.4-5 \mathrm{~mm}$ wide. Ligule obtuse, membranous, papery, 4-9 mm long, glabrous; auricles absent. Leaf blade subterete, permanently folded, $0.6-1.1 \mathrm{~mm}$ wide, to c. $70 \mathrm{~cm}$ long with a needle-like point; abaxial surface smooth and shiny; adaxial surface slightly ribbed, with hairs $0.05-0.2 \mathrm{~mm}$ long; margins glabrous or scabrous with stiff hairs $0.1-0.2 \mathrm{~mm}$ long. Panicle $10-25 \mathrm{~cm}$ long, exserted, $1-3.5 \mathrm{~cm}$ wide (excluding awns); axis slightly flattened, smooth, glabrous; branches to c. $4.5 \mathrm{~cm}$ long, glabrous or with a few scattered hairs c. $0.7 \mathrm{~mm}$ long; pedicels to $1 \mathrm{~cm}$ long, glabrous. Spikelets (12-) 15-20 mm long (excluding awn), laterally compressed, gaping. Glumes equal to subequal, rounded on the back, acute, straw-coloured, sometimes purplish at the base, glabrous; lower glume (12-) 14-20 mm long, lower $50 \%$ 1-3-nerved; upper glume (12-) 14-18 mm long, lower $60 \% 3-5(-6)$-nerved, remainder 1-2-nerved. Floret cylindrical, $8-13 \mathrm{~mm}$ long (including callus). Lemma very faintly granular, pilose with hairs $0.5-2.5 \mathrm{~mm}$ long; lobes $2,(0.5-)$ 1.5-2.0 (-3.0) mm long, ciliate; coma obscure, of few hairs $2-3.5 \mathrm{~mm}$ long. Callus $1.0-2.5 \mathrm{~mm}$ long, \pm straight, with dense white to light brown hairs to $\mathrm{c}$. $1.2 \mathrm{~mm}$ long. Awn $20-40 \mathrm{~mm}$ long, weakly twice bent, $(0.1-) 0.2 \mathrm{~mm}$ wide at the base; column $10-15 \mathrm{~mm}$ long, $4-10 \mathrm{~mm}$ to the first bend, scabrous with hairs $0.05-0.25 \mathrm{~mm}$ long; bristle scabrous with hairs less than $0.1 \mathrm{~mm}$ long. Palea equal to the lemma, slightly depressed between the nerves, acute, pilose down the centre with hairs similar to those on the lemma, margins smooth and glabrous, 2-nerved. Lodicules $3 ; 2$ abaxial $1.2-2.0 \mathrm{~mm}$ long, tips acute to \pm erose; paleal 1.5-3 mm long, acute. Anthers 5.5-8.5 mm long, penicillate. Caryopsis $4 \mathrm{~mm}$ long; embryo $25 \%$ the length; hilum $75-90 \%$ the length.

Distribution: Coastal areas of southern New South Wales, Victoria, Tasmania, South Australia and New Zealand.

Selected Specimens: New South Wales: South Coast: Devils Hole, 2 miles [3 km] NE. of Pt Perpendicular, Jervis Bay, Constable NSW 115818, 2.1960 (NSW); Cave Beach, 3 miles [5 km] SW. of Jervis Bay, Coveny 3682, 10.1971 (NSW, CANB, BRI, MEL); 27 km NNE. of Batemans Bay, Crisp 6736, 4.10.1980 (CBG); Camel Beach, Wallaga, Everett 451 \& Jacobs, 22.10.1981 (NSW); Boydtown, Everett 443 \& Jacobs, 22.10 .1981 (NSW); Towamba River, nr. Kiah, Gauba CBG $003956,16.11 .1954$ (CBG, MEL). 
Victoria: Region E: Lower Glenelg River, Beauglehole 5891, 28.12.1963 (NSW, AD, MEL). Region N: Altona Saltworks, Corrick 2903, 11.11 .1972 (Corick herb.). Region P: shores of Port Phillip, French, s.d. (CANB 134047); c. $10 \mathrm{~km} \mathrm{E.} \mathrm{of} \mathrm{Lara,} \mathrm{Allen,} \mathrm{7.10.1977} \mathrm{(MEL} \mathrm{522361);}$ Tooradin, Blake 7301, 20.1.1935 (BRI); Swan Bay, Jacobs 3667, 31.10.1979 (NSW); Mornington Peninsula, Muir 6436, 23.11.1978 (MEL); Western Port Bay, Muir 948, 16.11.1959 (NSW, AD, MEL, CANB). Region X: 90 Mile Beach, Jacobs 2396 \& Williams, 16.11.1975 (NSW). Region Z: Mallacoota, Gauba CBG 003957, 16.11.1954 (CBG); c. 8.5 miles [14 km] SSW. of Mallacoota, Beauglehole 31125, 9.10.1969 (NSW).

TASmania: nr. George Town, Stuart NSW 116692, s.d. (NSW); hill above Derwent Estuary, Burbidge 3183, 18.1.1949 (CANB); Marion Bay, Hemsley 6687, 3.1.1972 (NSW); Clairmont, Lucas NSW 116688, 12.1923 (NSW); Risdon, Vickery NSW 7491, 18.1.1949 (NSW), Blake 18322, 18.1.1949 (BRI, NSW); Sandy Bay, Rodway NSW 116693, 11.1898; Taroona Beach, Townrow 6, 11.1966 (JEST); Kingston Beach, Rodway NSW 116694, 25.11.1935 (NSW); Eaglehawk Neck, Blake 18280, 15.1.1949 (BRI, NSW); Ralphs Bay, Townrow 54, 54a 22.11.1967 (JEST); Premaydena, Jacobs 2016, 2.2.1975 (NSW); Bond Bay, Port Davey, Davis 1268, 14.3.1954 (MEL); Partridge Island, Townrow, 12.2.1975 (JEST); Southport, Phillips \& Vickery NSW 116698, 20.1.1962 (NSW, CBG).

South Australia: Eyre Peninsula: Hundred of Flinders, Specht 2670, 10.11.1960 (AD). Murray: edge of Lake Alexandrina, Hilton, 9.10.1954 (ADW 28120). Yorke Peninsula: Royston Head, Weber 4266, 11.10.1974 (AD); Stenhouse Bay, Symon 9549, 6.10.1974 (ADW, NSW). Southern Lofty: Waitpinga, Cleland, 25.1.1932 (AD 97421168). Kangaroo Island: Kangaroo I., Tate, 16.11.1883 (MEL, AD); Kingscote, H.H.D.G. [?], 28.10.1908 (AD), Eichler 15250, 6.11.1958 (AD); Peneshaw, Hilton 3.12.1945 (ADW 43980); Hog Bay. Cleland, 15.11.1924 (AD); Dudley Peninsula, Tate 21.11.1883 (AD 97427497, 97427496); Pennington Bay, Cleland, 6.3.1926 (AD); South-West River, Cleland 7.11.1934 (AD); Remarkable Rocks, Phillips CBG 042830, 2.9.1965 (CBG). South-eastern: Vivonne Bay, Latz, 11.2.1972 (NT 62993); Woods Well, Cleland, 15.10.1955 (AD); Coorong, Cleland NSW 116677, 12.1922 (AD, NSW); S. of Banff, Symon 10508a, 11.10.1975 (NSW, dupl. of ADW); Lower Coorong, Symon 10469, 4.10.1975 (NT); between Kingston \& Naracoorte, Riceman, 1.1936 (ADW); Robe, Eardley, 1.1938 (ADW); Dombey Cape, Symon, 26.11.1959 (ADW 21800); Beachport, Black, 30.11.1917 (AD 97421167); Rivoli Bay, Cleland, 5.3.1944 (AD); E. of Port MacDonnell, Eardley 3.2.1942 (ADW 4942).

Veldkamp (ibid.) cites Dichelachne setacea Nees in Lehmann, Pl. Preiss. 2: 98 (1846), as a synonym of Stipa stipoides (Hook. f.) Veldkamp, citing a specimen of Preiss 1854 in BM as the Holotype of Dichelachne setacea. This specimen seems to have been subsequently misplaced and cannot now be found. Two specimens of Preiss 1854, one in LD and one in MEL, are S. juncifolia Hughes. Veldkamp was not aware that $S$. stipoides, always with a contracted panicle, is confined to littoral habitats, and would not be present 'In regionibus interioribus Australiae meridionale - occidentalis' as cited by Nees. S. juncifolia does have long lemma lobes, similar to $S$. stipoides, but differs in having an effuse panicle, elongate ligule, smaller glumes and floret, and a longer awn.

Stipa stuposa Hughes, Kew Bull. 1921: 20 (1921); Townrow, Pap. \& Proc. Roy. Soc. Tasmania 112: 259 (1978).

Holotype: TAsmania: New Norfolk, Gunn 1480, 5.1.1840 (K!, also CANB photo 235994). The Holotype sheet bears, in addition to the main specimen, some fibrous material resembling partially unravelled twine that Gunn has annotated 'Produce I believe of 1480 '. It is doubtless this material that caused Hughes to describe the base of the plant as finally breaking up into very long twisted fibres. This condition is believed to be pathological. Similar material is known to be caused by the fungal pathogen Tolyposporium restifaciens (Ropey Smut) in other species of Stipa (J. Walker, pers. comm.).

Caespitose perennial to c. 1 metre high, without rhizomes, with a basal tuft of leaves to about a third the height. Culms erect or geniculate at the base, terete, $1.5-6 \mathrm{~mm}$ wide near the base, not compressible, slightly ribbed, glabrous, scaberulous to pubescent with hairs minute $-1 \mathrm{~mm}$ long; nodes c. 3 , exserted, densely sericeous with hairs c. $0.2 \mathrm{~mm}$ long, to $50 \%$ wider than adjacent 
internodes. Leaf sheaths at first tightly enveloping the culm, later becoming loose, 4-10 $\mathrm{mm}$ wide, slightly ribbed to strongly ribbed on upper sheaths, glabrous to hirsute with hairs minute $-0.4 \mathrm{~mm}$ long; inner margin glabrous; outer margin glabrous to sparsely ciliate with hairs $0.1-0.3 \mathrm{~mm}$ long, rarely longer on upper sheaths; collar glabrous or ciliate with hairs minute- $-0.6 \mathrm{~mm}$ long. Ligule truncate, membranous to coriaceous, $0.5-1 \mathrm{~mm}$ long, ciliate with hairs minute $-0.2 \mathrm{~mm}$ long; abaxial surface densely sericeous with hairs to $0.4 \mathrm{~mm}$ long; auricles thickened, ciliate at the base with hairs minute- $1.5 \mathrm{~mm}$ long. Leaf blade loosely rolled, $2-4 \mathrm{~mm}$ wide, to $35 \mathrm{~cm}$ long; abaxial surface smooth to moderately ribbed, glabrous to scaberulous with minute hairs and tubercles or pubescent with hairs $0.1-0.5 \mathrm{~mm}$ long; adaxial surface strongly ribbed, scaberulous to pubescent with hairs minute- $0.3 \mathrm{~mm}$ long; margins scaberulous to ciliate with hairs c. $1 \mathrm{~mm}$ long, or similar to the abaxial surface. Panicle $20-35 \mathrm{~cm}$ long, exserted, with moderately distant fascicles of unequal, few- to many-flowered branches, \pm contracted or slightly expanded, $2.5-5 \mathrm{~cm}$ wide (excluding awns); axis terete to slightly flattened, scaberulous to scabrous with hairs minute- $0.1 \mathrm{~mm}$ long; branches and pedicels angular to terete, scabrous along the edges with hairs minute- $0.3 \mathrm{~mm}$ long; branches $3-6 \mathrm{~cm}$ long; pedicels $0.2-1 \mathrm{~cm}$ long. Spikelets $15-23 \mathrm{~mm}$ long (excluding awn), gaping. Glumes unequal, acuminate, straw-coloured, scaberulous along the ribs with hairs minute $-0.2 \mathrm{~mm}$ long, puberulous elsewhere; lower glume 5-23 mm long, lower $50-85 \%$ 3-nerved; upper glume $12-19 \mathrm{~mm}$ long, lower $(20-) 40-50 \%$ (7-) 5-3nerved, upper (80-) 60-50\% (5-) 3-1-nerved. Floret narrowly turbinate without a neck, 7-12 mm long (including callus). Lemma smooth to granular, sericeous with white hairs $0.5-1.5 \mathrm{~mm}$ long turning gold at maturity; lobes 2 when present, $0.1-0.2 \mathrm{~mm}$ long, ciliate with minute hairs; coma of dense, erect hairs, 1-3 mm long. Callus $1.5-2.5 \mathrm{~mm}$ long, densely sericeous with white hairs $0.1-1$ $(-1.5) \mathrm{mm}$ long turning gold at maturity. Awn 45-70 mm long, with 2 bends, $0.2-0.4 \mathrm{~mm}$ wide near the base; column $20-25 \mathrm{~mm}$ long, $6-10 \mathrm{~mm}$ to the first bend, brown, pubescent to villous with hairs $0.5-1 \mathrm{~mm}$ long; bristle strawcoloured, scabrous with hairs minute $-0.2 \mathrm{~mm}$ long. Palea equal to the lemma, acute, smooth along the edges, slightly granular down the centre, glabrous to sericeous down the centre back with hairs $0.2-1 \mathrm{~mm}$ long. Lodicules 2, membranous, abaxial, acute or obtuse, 1.5-2 mm long. Anthers c. $1 \mathrm{~mm}$ long, penicillate. Caryopsis 4-5 mm long; embryo $20-35 \%$ the length; hilum $70-90 \%$ the length.

DiSTRIBUTION: Scattered through southern New South Wales and Victoria, common in Tasmania.

Selected Specimens: New South Wales: South Coast: Eden, 3704'S, $149^{\circ} 55^{\prime}$ E, Everett 449 \& Jacobs, 22.10.1981 (NSW); Twofold Bay, Davis NSW 115820, 27.12.1952 (NSW); Boydtown, Nullica Bay, $37^{\circ} 06^{\prime}$ S, $149^{\circ} 53^{\prime} \mathrm{E}$, Everett 445 \& Jacobs, 22.10 .1981 (NSW). South Western Plains: Lake Cargellico, Boorman NSW 117408, 10.1906 (NSW); Mt Melongel, Gauba CBG 067328, 19.11.1950 (CBG); Griffith, Jacobs 4161, 24.9.1981 (NSW).

Victoria: Region C: Wimmera, Reader, I892 (MEL). Region D: 2.5 miles [4 km] W. of Dergholm, Beauglehole 38079, 24.2.1971 (ACB). Region H: Western Highway, NW. of Dadswells Bridge, Beauglehole 30100A, 18.12.1968 (NSW). Region N: Observatory grounds, S. Yarra, Morris, 14.11.1946 (MEL). Region P: Moorabool River, Carr \& Adair 7285, 18.1.1981 (NSW). Region R: 5 miles [8 km] S. of Buckland, Townrow, 24.11.1962 (BRI). Region W: NE. of Omeo, Beauglehole 36852, 20.2.1971 (NSW); between Ensay N. \& Ensay S., Beauglehole 37030, 24.2.1971 (ACB); c. 6 miles [9 km] W. of Lakes Entrance, Metung road, Muir 1956, 29.11.1960 (MEL); Kalimna Bluff, Wakefield 2525, 3.1948 (MEL).

TASMANIA: Big Green I., Whinray 334, 25.10.1968 (AD); Launceston, no collector, 12.1888 (MEL 60821); Evandale, Townrow I15, 12.1967 (JEST); Cressy, Townrow 120, 20.12.1967 (NSW); Poatina, Townrow 7, 5.4.1967 (HO); nr. O'Connors Peak, Townrow 116, 19.12.1967 (NSW); 3 miles [5 km] W. of Orford, Townrow 69, 24.11.1967 (JEST); nr. Runnymede, Phillips 577, 4.11.1960 
(NSW); Risdon, Burbidge 3185, 18.1.1949 (CANB); Cambridge side of Warrane, Townrow, 5.4.1967 (HO); N. of Lindisfarne, Townrow 100, 13.12.1967 (JEST); Hobart, Blake 18268, 14.1.1949 (BRI, NSW); Derwent Valley, Martin NSW 116801, 12.1933 (NSW); Mt Nelson, Curtis, 1.2.1947 (BRI); Slopen I, Townrow 86, 12.1967 (JEST); Bonnet Hill, Townrow 164, 1.1968 (JEST); 3 miles [5 km] S. of Opossum Bay, Townrow 50, 11.1967 (JEST); North Bruny I., Townrow 159, 4.1.1968 (JEST); South Bruny I., Phillips CBG 046199, 29.11.1965 (CBG).

South Australia: Southern Lofty: Black Hill, Spooner 1691, 18.11.1971 (AD).

Stipa tenuifolia Steudel, Syn. Pl. Glum. 1: 128 (1854); Hughes, Kew Bull. 1921: 12 (1921); Gardner, Fl. W. Austral. 1, Gram.: 180 (1952).

Holotype: Drummond Coll. IV, 391 N. Holl. (P!; presumed isotypes K, MEL 59997). Gardner (loc. cit.) states that Drummond 220 is the Type, but this number was not cited in the protologue.

Synonyms: S. eriopus Benth., Fl. Austral. 7: 570 (1878); Hughes, Kew Bull. 1921: 12 (1921); Gardner, Fl. W. Austral. 1, Gram.: 179 (1952). HolotyPE: WeStern Australia: Swan River, Drummond 962 (K!, isotype MEL 59927, CANB photo 237024). The Type specimen is exceptionally woolly-hairy at the base (though scarcely bulbous) and the leaves are strongly curved. Similar hairs are present, but less conspicuous, on numerous other specimens, and the leaves often tend to curve on drying.

S. scabra var. occidentalis Benth., FI. Austral. 7: 571 (1878). LECTOTYPE, here designated: Western Australia: Drummond 391 (K). In the protologue Bentham cites three synonyms: $S$. flavescens Nees non Labill., S. tenuifolia Steud. and S. puberula Steud., and cites a number of specimens from Western Australia including Drummond 391 (the Holotype number of S. tenuifolia), Drummond 220, 960 and 963 and Murchison River, Oldfield, Frasers Range, Dempster and Champion Bay, C. Gray (which are all S. tenuifolia) and Drummond 379 (the Holotype number of $S$. puberula Steud.). Examination of duplicates of the 'Type' of 'S. flavescens Nees non Labill.' (Preiss 1826) in LD and HBG (no specimen now extant at B) has shown that it does belong to $S$. flavescens Labill. though excluded from that species by Bentham, perhaps on account of its unusually spreading inflorescence (see notes under $S$. flavescens). Bentham's brief description of var. occidentalis: 'Spikelets usually rather larger and fewer' [than S. scabra Lindl.] appears to fit $S$. tenuifolia Steud. much more aptly than $S$, puberula Steud. We therefore agree with Hughes in treating $S$. scabra var. occidentalis as a synonym of $S$. tenuifolia Steud. Hughes also cites the variety under $S$. puberula Steud.

S. scabra var. pubescens Benth., FI. Austral. 7: 571 (1878). LECTOTYPE, here designated: WESTERN Australia: Drummond 375 (K). Bentham cites Drummond 375 (K!, dupl. MEL 59943) and 973 (K!, dupl. MEL 59944). Hughes cites Drummond 375 as the Holotype of $S$. incurva Hughes and cites $S$. scabra var. pubescens as a synonym. She also cites Drummond 973 under $S$. incurva. Both specimens are $S$, tenuifolia.

S. leptophylla Hughes, Kew Bull. 1921: 14 (1921). HolotyPE: WeStern Australia: Swan River, Drummond 381 (K!, CANB photo 237017).

S. incurva Hughes, Kew Bull. 1921: 16 (1921); Black, Fl. S. Austral. edn 2: 87 (1943), p.p. HolotyPE: Western Australia: Swan River, Drummond 375 (K!, isotype MEL 59943), indicated as such by Hughes with an asterisk. Hughes also cites Drummond 973 (K!, dupl. MEL 59944) and $S$. scabra var. pubescens Benth. as synonyms. The foliage of the two Drummond specimens is rather more hirsute than the majority of the specimens of $S$. tenuifolia, and the pubescence on the column is sparse in Drummond 375.

Caespitose perennial $0.6-1$ metre high with a sparse basal tuft of usually conspicuously extravaginal shoots to $40 \mathrm{~cm}$ high. Culms erect or occasionally geniculate, compressible, terete, $0.8-2(-2.5) \mathrm{mm}$ wide near the base, slightly ribbed, puberulous, especially just below the nodes, or scaberulous or glabrous upwards; nodes $2-3$, rarely exserted, to $60 \%$ wider than adjacent internodes, glabrous or occasionally very sparsely pubescent. Leaf sheaths tightly enclosing the culm, ribbed; lowermost sheaths villous with long, appressed hairs, or rarely pubescent; upper sheaths puberulous, scaberulous, or glabrous; inner margin glabrous; outer margin sparsely to densely ciliate especially just below the 
nodes. Ligule thinly coriaceous, $0.8-1 \mathrm{~mm}$ long in the middle, to $4 \mathrm{~mm}$ long where continuous with sheath-margin lobes, ovate to obliquely truncate, minutely ciliate or \pm glabrous, occasionally densely pubescent on the back; auricles thickened, spreading; sheath margin lobes with a dense line of long and thick hairs. Leaf blades to $30 \mathrm{~cm}$ long, flexuous or sinuous, usually inrolled, $0.5-1.5 \mathrm{~mm}$ diameter, occasionally expanded and to $3 \mathrm{~mm}$ wide; abaxial surface unribbed to slightly ribbed, scabrous with short or long stiff hairs or densely hirsute and scabrous; adaxial surface strongly ribbed, hirsute or pubescent, occasionally glabrous; margins similar to abaxial surface. Panicle to $35 \mathrm{~cm}$ long, exserted, spreading, to $5 \mathrm{~cm}$ wide (excluding awns), usually sparse, occasionally denser, with moderately close fascicles of usually few-flowered branches; axis terete, strongly scabrous; branches to $8 \mathrm{~cm}$ long, terete, scabrous; pedicels to $25 \mathrm{~mm}$ long, terete, minutely scaberulous or scabrous. Spikelets $13-20 \mathrm{~mm}$ long (excluding awn), usually gaping after floret disarticulation. Glumes unequal to almost equal, acuminate, usually purple-tinged; lower glume $13-20 \mathrm{~mm}$ long, membranous and translucent, the lower 30-50\% 3-nerved; upper glume $12-18 \mathrm{~mm}$ long, membranous and translucent at the tip, firmer and green or yellow at the base, the lower 25-35\% 5-nerved, the next 35-25\% 3-nerved. Floret linear, 7-8 (-9) mm long (including callus), with a well-defined neck, the 3 main nerves slightly thickened at the apex. Lemma finely granular, except tuberculate over the apex of the midvein, black-brown at maturity; hairs white, erect and spreading, sparse especially at the apex; coma obscure, of few hairs in two lateral tufts to $1.5 \mathrm{~mm}$ long, or absent; lobes usually 2 , to $0.4 \mathrm{~mm}$ long. Callus 2.1-3.1 mm long, straight, with dense white to pale yellow hairs. Awn $70-85$ (-120) mm long, $0.25-0.45 \mathrm{~mm}$ wide near the base, falcate; column 11-16 (-20) $\mathrm{mm}$ long, $7-12 \mathrm{~mm}$ to the end of the straight portion, densely pubescent or villous with slightly spreading hairs $0.2-0.4(-0.6) \mathrm{mm}$ long; bristle scaberulous. Palea $0.3-1.3 \mathrm{~mm}$ shorter than the lemma, broadly acute to obtuse, coriaceous down the centre with a line of white hairs; margins and tip membranous and glabrous. Lodicules 2, membranous, abaxial, 1.4-1.8 mm long, long-spathulate. Anthers $2.5-3.5 \mathrm{~mm}$ long, penicillate. Caryopsis 3-5 mm long; embryo $30 \%$ the length; hilum $80 \%$ the length.

DiSTRIBUTION: Southern regions of Western Australia and east to the Yorke Peninsula in South Australia.

Specimens Examined: South Australia: Eyre Peninsula: Reserve near Mt Verran, Cleland, 9.11.1960 (AD 968061284); Flora and Fauna Reserve. Hundred of Hincks, c. $85 \mathrm{~km} \mathrm{~N}$. of Port Lincoln, Specht 2563, 11.11.1960 (AD); S. of Coorabie, Cleland, 18.10.1953 (ADW 44063 in part). Northern Lofty: Kalimna Scrub, 1 mile $[1.6 \mathrm{~km}]$ NW. of Nuriootpa, 20 miles [32 km] NE. of Gawler, Hilton, (ADW 44097); Miananga, Barossa Valley, Hilton, 5.7.1951 (ADW 44107). Yorke Peninsula: Port Pirie, Koch NSW 116954, 9.1901 (NSW). Southern Lofty: Vine Vale, Barossa Valley, Hilton, 1.7.1951 (ADW 44106); c. 1 mile $[1.6 \mathrm{~km}] \mathrm{N}$. of Tanunda, Kraehenbuehl I655, 23.10.1966 (AD); Altona, via Lyndoch, 9 miles [14 km] E. of Gawler, Hilton, 11.1952 (ADW 44098, 44099); near Highbury Hotel, Kraehenbuehl 882, 22.10.1962 (AD, NSW); Halletts Cove, c. 25 km S. of Adelaide, Cleland, 9.10.1920 (AD); Port Noarlunga, Crisp 633, 14.10.1973 (CBG); Kuitpo Forest, Spooner 720, 28.9.1969 (AD). Kangaroo Island: Kingscote, at Reeves Point, Jackson 75, 8.10 .1960 (AD).

Western Australia: Austin: Murchison River, Oldfield, (MEL 59948). Coolgardie: Mt Malcolm, Fitzgerald NSW 116943, 7.1899 (NSW). Roe: Frasers Range, Dempster NSW 116831, [1876] (NSW). Irwin: Buller River, N. of Geraldton, Blake 18080, 2.9.1947 (BRI, PERTH, K); Champion Bay, Gray, 1873 (MEL 60027, 60028); 22 miles [35 km] N. of Geraldton in Oakabella Hills, Burbidge 2074, 2.9.1947 (CANB); Mingenew, Holms, 20.8.1934 (PERTH). Avon: Upper Irwin, Gwerin, (MEL 60004); 27.1 miles [35 km] from Carnamah towards Mingenew, Canning CBG 039490, 14.6.1968 (CBG); between Kunnunoppin \& Mt Marshall \& Lake Barlee, Fraser NSW 116830, winter-spring 1919 (NSW); c. 41 miles [66 km] S. of Marchagee, Maslin 1407, 10.10.1970 (PERTH); 5 miles $[8 \mathrm{~km}]$ from Goomalling towards Wongan Hills, Phillips CBG 039219, 12.9.1968 (CBG, 
NSW); $14.5 \mathrm{~km}$ from Wyalkatchem towards Dowerin, Phillips CBG 054857, 19.9.1962 (CBG); Merredin Research Station, Landfield, 10.1948 (PERTH); Grass Valley, Despeissis, 1898 (PERTH); Kellerberrin, Leake, 9.1897 (PERTH); Muntadgin, Bailey I76, 9.1945 (PERTH); Bruce Rock, Baxter, 10.1913 (PERTH); Quairading, Waters, 9.1957 (PERTH); 17 miles [27 km] E. of Pingelly, Aplin 773, 10.1960 (PERTH); 3 miles [5 km] W. of Wagin, Phillips, 28.10.1962 (CANB 027110); Kojonup, Symon, 9.1954 (ADW). Darling: York, Meadly, 6.12.1947 (PERTH); Perth, Maiden NSW 116942, 10.1909 (NSW); Meekering, 100 miles [160 km] S. of Perth, Symon, 9.1954 (ADW 44168); Kelmscott, Helms, 11.9.1897 (PERTH); Lake Banganup, Jandakot, Weston 9798, 2.11.1974 (PERTH); Medina, Aplin 1068, 10.1961 (PERTH); Capel, Royce 2698. 25.9.1948 (PERTH); Busselton, Gardner, 11.1936 (PERTH); Maryvale, Macpherson, 1898 (MEL 60006); Bremer Bay, Wellstead, 1900 (PERTH); Albany Highway, $25 \mathrm{~km} \mathrm{N.} \mathrm{of} \mathrm{Mt} \mathrm{Barker,} \mathrm{Pullen} \mathrm{10004,} \mathrm{12.12.1974}$ (CANB); King Georges Sound, Oldfield (MEL 59992). Eyre: between Jeramungup \& Ravensthorpe at West River Crossing, Canning, 10.11.1968 (CBG); Desmond, near Ravensthorpe, Maiden NSW 116949, 11.1909 (NSW); between Esperance Bay \& Frasers Range, Dempster, 1876 (MEL 60926).

$S$. tenuifolia is similar to $S$. variabilis but differs in the longer floret and awns and the longer, usually unequal glumes.

Stipa trichophylla Benth., Fl. Austral. 7: 570 (1878); Hughes, Kew Bull. 1921: 14 (1921); Gardner, Fl. W. Austral. 1, Gram.: 180 (1952).

Holotype: Western Australia: Drummond 122 (K!; isotype MEL 60010, 60011, CANB photo 237021).

Caespitose perennial to 0.6 metres high with a basal tuft of mainly intravaginal shoots to half the height. Culms erect but usually geniculate at the first node, easily compressible, terete, $0.8-1.5 \mathrm{~mm}$ wide near the base, smooth to slightly ribbed, glabrous (or the basal internodes puberulous) but sparsely to moderately pubescent or scaberulous just below the nodes; nodes $2-3$, exserted, to $50 \%$ broader than adjacent internodes, glabrous. Leaf sheaths tightly enveloping the culms although older basal sheaths often present and loose, ribbed, $2.5-5 \mathrm{~mm}$ wide, the uppermost sheath broader, to $7 \mathrm{~mm}$ wide; lowermost sheaths pubescent, almost glabrous, or villous with appressed hairs; upper sheaths glabrous to minutely scaberulous between the nerves; inner margin glabrous; outer margin long-ciliate, especially just below the orifice, or glabrous on the upper sheaths. Ligule membranous, $0.5-1 \mathrm{~mm}$ long where continuous with the sheath-margin lobes, usually much shorter in the middle, obtuse or laciniate, ciliate, auricles slightly thickened, not spreading, with a tuft of fine, straight or slightly crinkly hairs $1-1.7 \mathrm{~mm}$ long. Leaf blades to $20 \mathrm{~cm}$ long, very fine, erect or flexuose, tightly inrolled, $0.3-0.5 \mathrm{~mm}$ diameter; abaxial surface scarcely ribbed, hirsute with dense to sparse, soft, spreading hairs to $1 \mathrm{~mm}$ long, scabrous with a layer of shorter, stronger hairs; adaxial surface strongly ribbed, sparsely to densely hirsute with long hairs, margin similar to abaxial surface or with antrorse scabrous hairs. Panicle to $25 \mathrm{~cm}$ long, exserted, contracted, or occasionally spreading, 15-40 mm wide (excluding awns), sparse with moderately distant fascicles of few, sparsely-flowered branches; axis terete; axis, branches and pedicels scabrous to puberulous; branches angular to $8 \mathrm{~cm}$ long; pedicels to $15 \mathrm{~mm}$ long, very slender, flattened. Spikelets $9.5-14 \mathrm{~mm}$ long (excluding awn), slightly gaping after floret disarticulation. Glumes subequal to unequal, finely acuminate, purple-tinged at the ends of the nerves, otherwise straw-coloured, transparent and membranous at the tip, firm at the base; lower glume 9.5-14 mm long, the lower 50-70\% 3-nerved; upper glume 8-11.5 mm long, the lower $20-50 \%$-nerved, the next $10-40 \% 3$-nerved. Floret linear to fusiform, 3.8-6.5 mm long (including callus) with a slight neck, the 3 main nerves slightly prominent at the apex. Lemma finely granular except tuberculate over the apex of the midvein, gold-brown at maturity, the nerves paler; hairs 
white, erect and spreading, sparse especially at the apex; coma obscure, of few hairs in two lateral tufts to $1.5 \mathrm{~mm}$ long; lobes usually 2 , to $0.3 \mathrm{~mm}$ long. Callus $1.2-2.5 \mathrm{~mm}$ long, straight and fine, with dense white hairs. Awn 38-60 (-75) $\mathrm{mm}$ long, $0.15-0.35 \mathrm{~mm}$ wide near the base, falcate; column 6-10 $\mathrm{mm}$ long, densely pubescent with spreading hairs $0.15-0.3(-0.4) \mathrm{mm}$ long; bristle scaberulous. Palea $0.25-0.5 \mathrm{~mm}$ shorter than the lemma, broadly acute to obtuse, coriaceous down the centre with a line of white hairs; margins and tip membranous and glabrous. Lodicules 2, membranous, abaxial, $0.5-0.7 \mathrm{~mm}$ long, linear to slightly spathulate. Anthers $1.5-2 \mathrm{~mm}$ long, penicillate. Caryopsis 2.3-3 mm long; embryo $20-30 \%$ the length; hilum $40-50 \%$ the length.

DiSTRIBUTION: Scattered and uncommon in the drier areas of New South Wales, Victoria, South Australia, Northern Territory and southern Western Australia.

Selected Specimens: New South Wales: South Western Plains: Kyalite State Forest, $34^{\circ} 58^{\prime}$ S, $143^{\circ} 32^{\prime} \mathrm{E}$, Everett 52 \& Jacobs, 22.11.1980 (NSW). North Far Western Plains: Olive Downs Jump Up, $32^{\circ} 04^{\prime} \mathrm{S}, 141^{\circ} 55^{\prime} \mathrm{E}$, Everett 237 \& Jacobs, 6.9. 1981 (NSW).

Victoria: Region C: S. slope of Mt Arapiles, 365'S, $141^{\circ} 50^{\prime} \mathrm{E}$, Everett 366 \& Jacobs, 17.10 .1981 (NSW). Region D: 3.7 miles [6 km] W. of Tubbut, Beauglehole 33132 \& Finck, 5.1.1970 (NSW).

NORTHERN TERRITORY: 8 miles [13 km] WNW. of Ayers Rock, Lazarides 6152, 7.9.1956 (NSW); 37 miles [43 km] NE. of Docker River Settlement, Latz 868, 28.10.1970 (NT, CANB).

SOUTH AUSTRALIA: North-western: Government North West Expedition, Basedow 120, 1903 (NSW); Tompkinson Ranges, Cleland, 25.8.1954 (AD 96806194); c. $1.75 \mathrm{~km}$ WNW. of summit of Mt Poondinna, Whibley 6447, 29.8.1978 (AD). Lake Eyre Basin: Hamilton Creek, Langley 396, 9.1898 (AD). Flinders Ranges: Arkaroola, 30¹9'S, 139 ${ }^{\circ} 18^{\prime} \mathrm{E}$, Everett 245 13.9.1981 (NSW); Mt Gee, Kuchel 3167, 15.9.1973 (AD); Mt Chambers Gorge, Cleland, 31.5.1937 (AD 95714010); 'Moolooloo', between Blinman \& Beltana, Rogers NSW 116876, 10.1915 (NSW); above Aroona Valley, Symon 7241, 12.9.1971 (ADW, NSW); Wilpena Pound, 31 $31^{\prime} \mathrm{S}, 138^{\circ} 34^{\prime} \mathrm{E}$, Everett 266, 17.9.1981 (NSW); Melrose, Czornij 632, 10.10.1973 (AD). Eastern: 'Koonamore', Osborne, 18.12.1924 (AD 97741253); 'Mt Victor', Crisp 440, 4.9.1971 (CBG); Morialta, Vickery NSW 116873, 11.1938 (NSW). Eyre Peninsula: Gawler Range, Weber 3073, 23.9.1972 (AD); Warunda, White, 10.1909 (AD 97734167). Northern Lofty: South Hummocks Range, Blaylock 736, 1.10.1967; nr. Owen, Cleland, 30.10.1968 (AD 97350090). Murray: $15 \mathrm{~km} \mathrm{W.} \mathrm{of} \mathrm{Murray} \mathrm{Bridge,} \mathrm{Carrick} \mathrm{3805,}$ 2.10 .1974 (NSW); c. $25 \mathrm{~km}$ N. of Lameroo, Cleland, 13.10 .1960 (AD 968061298). Yorke Peninsula: 1.5 miles [2 km] N. of Winulta, Symon 1475, 14.9.1961 (ADW). Southern Lofty: 2 miles [3 km] WNW. of Gawler, Smith 959, 23.10.1967 (AD). South-eastern: $47 \mathrm{~km} \mathrm{~N}$. of Kingston, Symon 10548, 11.10.1975 (ADW, NSW); $3.7 \mathrm{~km} \mathrm{S.} \mathrm{of} \mathrm{Banff,} \mathrm{Symon} \mathrm{10414,} \mathrm{9.10.1975} \mathrm{(ADW,} \mathrm{NSW).}$

Western Australia: Eucla: Eucla, Noble NSW 116864, 8.8.1973 (NSW). Austin: 40 miles [64 km] E. of Meekathara, Royce 2004, 15.6.1947 (PERTH); Wiluna area, Morrisey 48, 12.1970 (PERTH); 4 miles [6 km] S. of Agnew, Beauglehole 59683 \& Errey, 14.9.1978 (NSW); Youanmi townsite, Saffrey 1023, 26.8.1970 (PERTH); Poison Creek via Leonora, McGregor NSW 116857, 9.1909 (NSW); 'Glenorn', Burbidge 114, 8.1938 (PERTH). Coolgardie: 30 miles [48 km] S. of Coolgardie, Smith 532, 16.9.1966 (NSW); Fraser Range, Beard 6301, 13.9.1970 (PERTH, NSW). Roe: 0.5 miles [1 km] E. of Julakin Rock, Malcom, 24.10.1959 (PERTH); Peak Charles, Newbey 6457, 11.11.1979 (PERTH); Desmond, Maiden NSW 116861, 11.1909 (NSW). Eyre: Cape Arid National Park, Royce 10145, 5.12.1971 (PERTH); 104 miles [168 km] W. of Esperance, Beauglehole 13094, 17.9.1965 (PERTH, NSW); Susetta Creek, Royce 9190, 21.10.1970 (NSW). Avon: 12 miles [19 km] NW, of Wialki, Storr NSW 150582, 4.10.1958 (PERTH); Merredin, Maiden NSW 116855. 10.1909 (NSW); Tammin; Maiden NSW 116863, 9.1909 (NSW); Northam, Gardner 6433 p.p., 7-8.9.1942 (PERTH); 17 miles [27 km] E. of Pingelly, Aplin 773, 10.1960 (PERTH); Wagin, Gardner, 10.1920 (PERTH). Carnarvon: 1 mile [1.5 km] S. of Wannoo, Phillips CBG 039486, 16.9.1968 (CBG). Irwin: Northampton, Helms NSW 116858, 10.1898 (NSW, PERTH); Pindar, Maiden NSW 116865, 10.1909 (NSW). Darling: Mt Barker, Gardner 1.1925 (PERTH). 
Stipa tuckeri F. Muell., Fragm. 9: 129 (1881); Hughes, Kew Bull. 1921: 11 (1921); Gardner, Fl. W. Austral. 1, Gram.: 172, pl. 50B (1952); Willis, Handb. Pl. Victoria 1: 181 (1962), edn 2: 181 (1970); Black, Fl. S. Austral. 1: 65 (1922), edn 2: 84 (1943).

HOLOTYPE: The specimen labelled 'Type' in MEL bears the following: [in an unidentified hand] 'Stipa Tuckeri, F.v.M. in Fragm. XI. p 128 (1881) Type.' [and in Mueller's hand] 'Stipa breviplumosa F.v.M. Between the Lach, and Darl. R. Not extending so far south as S. elegantissima. Garard Tucker' (MEL; dupl. NSW).

Caespitose perennial to c. 0.5 metres high, shortly rhizomatous, without a basal tuft of leaves but with many culm leaves. Culms erect to decumbent, terete, wiry, c. $1.5 \mathrm{~mm}$ wide near the base, frequently branching at the nodes, \pm compressible, smooth to strongly ribbed, lowest internodes glabrous, upper internodes pubescent with retrorse hairs 0.5-1 mm long; nodes 3-5, not swollen, not exserted, with sericeous hairs c. $0.6 \mathrm{~mm}$ long at the base of the node. Leaf sheaths at first tightly enveloping the culm, later becoming slightly free, pubescent with hairs $0.6-1 \mathrm{~mm}$ long, margins glabrous; lower sheath $4.5-7.5 \mathrm{~mm}$ wide, moderately ribbed; upper sheath $4.5-8.5 \mathrm{~mm}$ wide, weakly to strongly ribbed. Ligule obtuse, membranous, $2.5-6 \mathrm{~mm}$ long, glabrous to pubescent on the sides with hairs $0.2 \mathrm{~mm}$ long; auricles absent. Leaf blade expanded or loosely rolled, $0.3-1.2 \mathrm{~mm}$ wide, c. $13 \mathrm{~cm}$ long, strongly ribbed; abaxial surface pubescent with hairs $0.2-0.3 \mathrm{~mm}$ long to glabrous; adaxial surface pubescent with hairs $0.1-0.3 \mathrm{~mm}$ long; margins ciliate with hairs $0.2-0.5 \mathrm{~mm}$ long. Panicle 15-20 cm long, 10-17 cm wide (excluding awns), exserted, pyramidal with whorls of moderately long, few-flowered, compound branches, spreading widely at maturity; axis terete to slightly flattened, glabrous to plumose upwards with hairs c. $0.5 \mathrm{~mm}$ long; branches $5-6 \mathrm{~cm}$ long, slightly flattened to angular, plumose with hairs $0.3-0.6 \mathrm{~mm}$ long; pedicels $1-1.5 \mathrm{~cm}$ long, terete, plumose with hairs c. $0.3 \mathrm{~mm}$ long. Spikelets $6-7.5 \mathrm{~mm}$ long (excluding awn), gaping only at maturity. Glumes unequal, rounded on the back, purple with a strawcoloured tip, scabrous with hairs $0.1-0.2 \mathrm{~mm}$ long; lower glume $6-9 \mathrm{~mm}$ long, tip acute (to acuminate), lower 40-50\% 3-nerved; upper glume 5-9 mm long with an acuminate tip, lower 50-60\% 3-nerved, upper $40-50 \% 1$ ( -2 -nerved. Floret narrow-cylindrical, tapering to the apex, 4-5 $\mathrm{mm}$ long (including callus). Lemma dark brown, the surface tuberculate; coma obscure, $0.1-0.25 \mathrm{~mm}$ long; lobes absent. Callus $0.2-0.3 \mathrm{~mm}$ long, almost straight, with white hairs $0.2-0.5$ $(-0.8) \mathrm{mm}$ long. Awn $30-35 \mathrm{~mm}$ long, straight or once bent, $0.1-0.2 \mathrm{~mm}$ wide near the base, straw-coloured to dark-brown; column c. $10 \mathrm{~mm}$ long, scabrous with hairs $0.05-0.1 \mathrm{~mm}$ long; bristle scaberulous. Palea $20-35 \%$ the length of the lemma, obtuse, surface granular down the centre, margins smooth. Lodicules 2, abaxial, 2-3 mm long, oblong with acute tips. Anthers 1-1.5 mm long, not penicillate. Caryopsis 2.5-3 mm long; embryo $10-30 \%$ the length; hilum $50-60 \%$ the length.

Distribution: Mainly on the Western Plains of New South Wales but also on the North and Central Western Slopes, and in South Australia and Western Australia.

Selected Specimens: New South Wales: North Western Slopes: Liverpool Plains, no collector, no date (NSW 115816). Central Western Slopes: Trangie, Whittet NSW 115807, 3.1946 (NSW); Hutchens, 3.1947 (CANB 13121); 6 miles [9 km] S. of Tullibigeal, 'Wilga Plains' road, Ingram NSW $115805,9.1956$ (NSW). North Western Plains: c. 25 miles [40 km] SE. of Louth, Moore 4932, 21.4.1967 (NSW, CANB); 3 miles [5 km] N. of Cobar, Leigh NSW 97794, 10.1966 (NSW); Mt Boppy, Boorman NSW 115809, 11.1903 (NSW, K); Nyngan, Blakely NSW 115817, 10.1912 (NSW). South Western Plains: 3 km NE. of Gilgunnia, Pickard NSW 145675, s.d. (NSW); 5 miles [8 km] N. of Ivanhoe, Leigh NSW 115800, 4.1969 (NSW); between Lachlan \& Darling rivers, Tucker NSW 115815 , s.d. (NSW); Yenda, Nicholson NSW 115813, 6.1925 (NSW). 
South Australia: Eastern: 'Bibliando', nr. New West Bore, 31 $54^{\prime}$ 'S, $139^{\circ} 03^{\prime} \mathrm{E}$, Crisp 724, 12.4.1974 (CBG); N. of 'Baratta', SW. of Lake Frome, Cleland, 3.12.1930 (AD 97421157). Murray: $43 \mathrm{~km} \mathrm{~N}$. of 'Hypurna', $33^{\circ} 10^{\prime} \mathrm{S}, 140^{\circ} 54^{\prime} \mathrm{E}$, Conn 930, 12.9.1980 (AD).

Western Australia: Austin: 'Glenlorn', Malcolm, Burbidge 293, 8.1938 (PERTH). Coolgardie: Coolgardie-Esperance highway between Norseman \& Widgiemooltha, Willis, 3.10.1961 (MEL 1509516).

Stipa variabilis Hughes, Kew Bull. 1921: 15 (1921); Gardner, Fl. W. Austral. 1, Gram.: 182 (1952).

Holotype: Western Australia: Drummond 961 [which Hughes indicated by an asterisk as the Type] (K!; isotype MEL 59987, CANB photos 237000 and 237001). With her description, Hughes cites three purported synonyms and a number of specimens from four States. The first and second purported synonyms merely report misidentifications by the respective authors and, in view of her clear indication of the specimen she indicated as the Type of $S$. variabilis, have no claim for consideration as Type elements. The third appears to be a synonym of varietal rank, as discussed below. Of the specimens cited from Western Australia, Hughes herself (Kew Bull. 1922: 16 (1922)) casts doubt upon the identity of the three numbers collected at Kauring by Stoward (not seen by us). She accepted Drummond 961 as her Type, she also cited 'Ningham Country beyond the Arrowsmith River, Monger' which appears to be the Type of $S$. pubescens var, effusa Benth. We have seen three sheets: 'Beyond the River Arrowsmith, Monger' (MEL 60014), 'Ningham country, Monger' (MEL 60013,60012 ) which are apparent duplicates, and which are conspecific with S. variabilis. We consider it highly improbable that the sheets Hughes cites from South Australia, Victoria and Tasmania (not seen by us) represent $S$, variabilis. Although $S$. variabilis does occur in South Australia it is relatively uncommon and the earliest record is from 1946 indicating the possibility that $S$. variabilis is a comparatively recent introduction to South Australia.

SYNONYM: S. pubescens var, effusa Benth., Fl. Austral. 7: 750 (1878), as 'var. ?effusa'. HolOTYPE: WESTERN AUSTRALIA: 'Ningham country beyond Arrowsmith River, Monger' (K!; 3 apparent isotypes MEL 60012, 60013, 60014).

Caespitose perennial, to 0.8 metres high with a sparse basal tuft of mainly intravaginal shoots to a quarter the height. Culms erect or geniculate, compressible, terete, $0.6-1.0 \mathrm{~mm}$ wide near the base, slightly ribbed, glabrous but minutely puberulous just below the nodes, rarely sparsely puberulous overall; nodes $2-3$, barely exserted, to $50 \%$ broader than adjacent internodes, glabrous. Leaf sheaths tightly enveloping the culms, at length loose, ribbed; lowermost sheaths pubescent or almost glabrous or villous with long, appressed hairs; upper sheaths glabrous or scaberulous; inner margin glabrous; outer margin ciliate, especially just below the orifice or glabrous on the upper sheaths. Ligule thinly coriaceous, $0.5-1.0 \mathrm{~mm}$ long in the middle, to $2.0 \mathrm{~mm}$ long where continuous with sheath-margin lobes, obliquely truncate, glabrous; auricles thickened, spreading; auricles with a dense line of long thick hairs. Leaf blades to $25 \mathrm{~cm}$ long, flexuose, usually inrolled, $0.5-0.6 \mathrm{~mm}$ diameter, occasionally expanded, to $4 \mathrm{~mm}$ wide; abaxial surface scarcely ribbed, glabrous or occasionally scabrous to hirsute, especially on the basal leaves; adaxial surface strongly ribbed, sparsely to densely hirsute; margins similar to abaxial surface or with minute antrorse scabrous hairs. Panicle to $35 \mathrm{~cm}$ long, exserted, contracted or occasionally spreading, to $4 \mathrm{~cm}$ wide (excluding awns), sparse with moderately close fascicles of few, sparsely-flowered branches; axis terete, glabrous or scaberulous; branches to $9 \mathrm{~cm}$ long, terete, scaberulous; pedicels to $20 \mathrm{~mm}$ long, terete, scaberulous to scabrous upwards. Spikelets $10-13 \mathrm{~mm}$ long (excluding awn), slightly gaping after floret disarticulation. Glumes equal to unequal, acuminate, usually purple-tinged; lower glume $10-15 \mathrm{~mm}$ long, membranous and translucent, the lower 30-50\% 3-nerved; upper glume $8.5-12.5 \mathrm{~mm}$ long, membranous and translucent at the tip, firmer and green or yellow at the base, the lower 25-35\% 5-nerved, 3-nerved to $40-60 \%$. Floret 
linear to fusiform, 4.5-6.5 (-7) mm long (including callus) with a slight neck, the 3 main nerves slightly thickened at the apex. Lemma finely granular, except tuberculate over the apex of the midvein, black-brown at maturity; hairs white, erect and spreading, sparse especially at the apex; coma obscure, of few hairs in 2 lateral tufts to $1.0 \mathrm{~mm}$ long; lobes usually 2, to $0.25 \mathrm{~mm}$ long. Callus 1.6-2.2 mm long, straight and sturdy, sericeous with dense white to pale yellow hairs. Awn 50-70 (-90) $\mathrm{mm}$ long, (0.2-) 0.3-0.4 $\mathrm{mm}$ wide near the base, falcate; column 11-14 mm long, 6-11 mm to the end of the straight portion, densely pubescent or villous with spreading hairs $0.2-0.5 \mathrm{~mm}$ long; bristle scaberulous. Palea $0.3-0.5 \mathrm{~mm}$ shorter than the lemma, broadly acute to obtuse, coriaceous down the centre with a line of white hairs; margins and tip membranous and glabrous. Lodicules 2, membranous, abaxial, 1.0-1.6 mm long, long-spathulate. Anthers $1.5-2.8 \mathrm{~mm}$ long, lightly penicillate. Caryopsis 3-4 mm long; embryo $25-30 \%$ the length; hilum $70-75 \%$ the length.

DistRIBUTION: Southern Western Australia and eastwards to southern regions of South Australia.

Selected Specimens: South Australia: Nullarbor: 15 km E. of 'Koonalda', Chinnock 1192, 21.9.1973 (AD); Nullarbor Plain, Hilton, 22.8.1955 (ADW 1977). Eyre Peninsula: 9 km NE. of Penong, Crisp 6362, Taylor \& Jackson, 5.10.1979 (CBG); c. 146 km S. of Kingoonya, Iron Knob road, Orchard 939, 26.8.1968 (AD). Northern Lofty: Tothill Range, Kraehenbuehl 1084, 27.10.1964 (AD). Yorke Peninsula: Kadina Mine dump, Lothian 3032, 3.11.1964 (AD). Southern Lofty: Elizabeth, Kraehenbuehl 1428, 20.6.1965 (AD); Anstys Hill, Cleland, 14.9.1946 (AD 96326158); Black Hill nr. Athelstone, Spooner 5318, 2.9.1977 (AD 97813108); National Park [Belair], Cleland, s.d. (AD 95714025); Woodville, Cleland, 9.9.1948 (AD 96326138); Victor Harbor, Hilton, 15.10.1955 (ADW 13246). South-eastern: nr. Keith, Specht, 9.1949 (AD 96514010).

WESTERN AUSTRALIA: Eucla: 50 miles [80 km] NNE. of Rawlinna, Brooker 172, 5.9.1974 (CANB); Forrest, Aplin 1647, 31.8.1962 (PERTH); $62 \mathrm{~km} \mathrm{S.} \mathrm{of} \mathrm{Rawlinna,} \mathrm{Cocklebiddy} \mathrm{road,} \mathrm{George} \mathrm{11882,}$ 13.7.1974 (PERTH, NSW); Western Australia-South Australia border, Eyre Highway, Phillips 258, 8.9.1962 (CBG); c. $1 \mathrm{~km} \mathrm{N.} \mathrm{of} \mathrm{Eucla,} \mathrm{Beauglehole} \mathrm{49433,} \mathrm{30.8.1974} \mathrm{(CANB).} \mathrm{Austin:} \mathrm{W.} \mathrm{of}$ Youanmi, Aplin 6089(a), 1.9.1975 (PERTH); Laverton, Maiden NSW 117001, 1.9.1909 (NSW). Coolgardie: 9 miles [14 km] W. of Coolgardie, Phillips CBG 027104, 16.9.1962 (CBG); between Norseman \& Coolgardie, Canning 2637, 5.9.1968 (CBG, NSW); 48 km W. of Coonana nr. Cardonia Rocks, Chinnock 1116, 18.9.1973 (AD); Fraser Range, Dempster, 1876 (MEL 59986, 60905); 2.5 miles [4 km] from Caiguna towards Madura, Canning CBG 039218, 4.9.1968 (CBG, NSW); Woodline, Cleland s.d. (AD 966050958). Roe: Pallarup Rocks, SE. of Lake King, George 1546, 13.10.1960 (PERTH). Eyre: Israelite Bay, Brookes NSW 151491, 9.1915 (NSW); Munglinup River, Esperance-Ravensthorpe road, Canning 7079, 7090, 3.11.1968 (CBG); West River, between Jeramungup \& Ravensthorpe, Canning 7548, 10.11.1968 (CBG, NSW); between Esperance Bay \& Fraser Range, Dempster 1876 (MEL 60937); Observatory I., 3356'S, 121 $48^{\prime} \mathrm{E}$, Weston 9415 , 2.6.1974 (PERTH); Lort River, Esperance-Ravensthorpe road, Jackson 1365B, 9.10.1968 (AD, PERTH); Susetta River, George 10011, 13.7 .1970 (PERTH); Fitzgerald River, George 10558 (PERTH), 10571 19.12.1970 (PERTH, NSW); Stirling Range, Nelson ANU 16802, 24.10.1972 (CANB); Young River, Esperance-Ravensthorpe road, Donner 2968, 10.10.1968 (AD, PERTH). Avon: Mingenew, Holmes, 20.8.1934 (PERTH); Three Springs, Canning 3347, 23.9.1968 (CBG, AD); 46 miles [74 km] N. of Coorow, Phillips CBG 018892, 25.9.1962 (CBG); 35.6 miles [57 km] from Wubin towards Wongan Hills, Canning 2889, 13.9.1968 (CBG. BRI); 3-4 miles [5-6 km] from Nórtham, Salasoo 241, 244, 15.10.1949 (NSW). Irwin: Northampton, Galbraith 573, 27.8.1964 (MEL); Minninnooka [?Moonyoonooka] 25 miles [40 km] E. of Geraldton, Morris, 9.1947 (MEL 60023, 60026). Darling: 15 miles [24 km] from Jurien Bay towards Moora Phillips 1678, 25.9.1968 (CBG, BRI); Moora, Blake 18049, 1.9.1947 (BRI, PERTH); c. 6 miles [9 km] S. of New Norcia, Beard 7935, 30.9.1976 (NSW, PERTH); Gingin, Gardner, 7.12.1923 (PERTH); Darling Range, Morris, 9.1947 (MEL 60017, 60018); 25 km N. of Mt Barker, Pullen 10004, 12.12.1974 (NSW).

The specific epithet has been applied to a range of species (nearly all of the Falcateae) by Australian collectors and authors in recent years, and their identifications and descriptions must be regarded with caution.

S. variabilis is characterised by a floret $4.5-7 \mathrm{~mm}$ long and a densely pubescent column of the awn. 
Stipa velutina J. Vickery, S.W.L. Jacobs \& J. Everett, sp. nov.

S. flavescenti affinis, sed pilis velutinis laminarum foliorum vaginarumque, glumis pubescentibus, flosculo plerumque breviore, differt.

Holotype: South Australia: Nullarbor: Head of Bight, J.C. Noble 7, 7.8.1973 (NSW 117409).

Caespitose perennial $0.3-0.8$ metres tall, without rhizomes. Shoots conspicuously extravaginal, flexuose, half to equal the height. Culms geniculate at the base, terete, \pm compressible, $1.5-2 \mathrm{~mm}$ wide near the base, sparsely ribbed to strongly ribbed upwards, velutinous with dense soft minute hairs; nodes to $50 \%$ wider than the adjacent internodes, exserted, velutinous with hairs $0.2-0.5 \mathrm{~mm}$ long. Leaf sheaths tight around the culms, uppermost slightly inflated at the base of the panicle, moderately ribbed, velutinous with hairs minute-1 mm long; basal sheaths glabrous on innovations, $4-8 \mathrm{~mm}$ wide, outer margin long-ciliate with hairs $0.2-0.5 \mathrm{~mm}$ long, inner margin glabrous; upper sheaths $4-5 \mathrm{~mm}$ wide, outer margin long-ciliate with hairs $0.2-1 \mathrm{~mm}$ long, inner margin glabrous. Ligule membranous, broadly obtuse to truncate, often erose, $0.2-1 \mathrm{~mm}$ long, sericeous on the abaxial surface, ciliate with hairs $0.1-0.3 \mathrm{~mm}$ long; auricles \pm thickened, c. $1 \mathrm{~mm}$ long, with tufts of straight hairs $1 \mathrm{~mm}$ long. Leaf blades linear, expanded or loosely inrolled, 2-3 mm wide, to $40 \mathrm{~cm}$ long, margins and both surfaces velutinous with hairs minute- $-0.1 \mathrm{~mm}$ long; abaxial surface smooth to moderately ribbed; adaxial surface strongly ribbed. Panicle contracted, $15 \mathrm{~cm}$ long, $0.5-2 \mathrm{~cm}$ wide (excluding awns), with closely spaced fascicles of unequal, few-flowered, compound branches, exserted late; axis terete, velutinous with hairs minute $-0.2 \mathrm{~mm}$ long; branches angular, to $3.5 \mathrm{~cm}$ long, pubescent with hairs $0.1-0.2 \mathrm{~mm}$ long; pedicels angular, 1-5 mm long, pubescent with hairs $0.1-0.2 \mathrm{~mm}$ long. Spikelets slightly gaping, 9-12 mm long (excluding awn). Glumes unequal, sparsely pubescent with hairs minute to $0.5 \mathrm{~mm}$ long; lower glume 9-12 mm long, long-acuminate, lower $20-35 \%$ 3-nerved, upper 65-80\% 2-1-nerved, green-yellow at the base but purple-tinged for most of its length; upper glume $6.5-10 \mathrm{~mm}$ long, acute to acuminate, lower $25-50 \%$ 5-nerved, upper $50-75 \%$ 3-1-nerved, green-yellow, purple at the tip. Floret narrow-fusiform, 5-6.5 mm long (including callus). Lemma surface slightly granular, with soft spreading white hairs $0.5-1.5 \mathrm{~mm}$ long; coma $0.1-0.5 \mathrm{~mm}$ long, formed from the upper hairs; lobes absent or 2, $0.1-0.2 \mathrm{~mm}$ long. Callus straight, 1-2 mm long, densely sericeous with white hairs $0.1-0.8 \mathrm{~mm}$ long. Awn $0.2 \mathrm{~mm}$ wide at the base, $30-45 \mathrm{~mm}$ long with two bends; column straw-coloured, $10-25 \mathrm{~mm}$ long, $7-9 \mathrm{~mm}$ to the first bend, pubescent with soft hairs $0.1-0.3 \mathrm{~mm}$ long; bristle straw-coloured, scaberulous. Palea subequal to the lemma, broadly acute to obtuse, slightly granular down the centre, sericeous down the centre with hairs $0.5-1.5 \mathrm{~mm}$ long, the tip ciliate with hairs $0.1-0.5 \mathrm{~mm}$ long. Lodicules 2, abaxial, oblong to acute, membranous, 0.8-1.2 mm long. Anthers 1-2 mm long, not penicillate. Caryopsis c. $3 \mathrm{~mm}$ long; embryo $15 \%$ the length; hilum $70 \%$ the length.

Distribution: Coast and islands of the Great Australian Bight.

SPECIMENS EXAMINED: SOUTH AUSTRALIA: Nullarbor: 'Nullarbor', Cleland, 12.11.1955 (AD 96324049); Head of Great Australian Bight, Whibley 616, 13.9.1960 (AD), Noble 7, 7.8.1973 (NSW 117409); Franklin I., Forrest, 22.2.1969 (ADW 36594); Masillon I., Nuyts Archipelago, Wace 41 5.1.1971 (AD); Fenelon I., Wace 279, 5.10.1972 (NT).

Western Australia: Eucla: 3.5 miles [6 km] E. of Eucla, George 8516, 15.10.1966 (PERTH); between Eucla \& Eilsons Bluffs, Phillips CBG 018888, 8.9.1962 (CBG). 
Stipa verticillata Nees ex Sprengel, Syst. Veg. 4, Cur. Post.: 30 (1827); Vickery, Contrib. N.S.W. Natl. Herb. 2: 77 (1953); Beadle, Evans \& Carolin, Handb. Vasc. Pl. Sydney District: 532 (1963), Fl. Sydney Region: 657 (1972); Veldkamp, Blumea 22: 10 (1974).

Streptachne verticillata (Nees ex Sprengel) Trin. \& Rupr., Mém. Acad. Imp. Sci. SaintPétersbourg, ser. 6, Sci., Math, Seconde Pt. Sci. Nat. 5: 8 (1842).

TYPIFICATION: 'Sieber Agrostotheca no. 64'. Sprengel's grass specimens were sold to Karl Muller and their whereabouts are now not known. Veldkamp (loc. cit.) claims that the Holotype is at LE but has not seen the specimen: he gives no reasons for making this claim. Isotypes are at $\mathrm{K}$, MEL and BRI (and elsewhere). The specimen at K(!) has usually been taken as the Type and is here designated as Lectotype.

SYNONYM: Stipa micrantha R. Br., Prodr.: 175 (1810), non Cav. (1799). Holotype: Australia: $R$. Brown, Iter Austral. 1802 (BM!, isotype: NSW 115965).

Caespitose perennial to c. 2 metres high, shortly rhizomatous, with numerous branches at each node, without a basal tuft. Culms erect, $(0.9-) 2(-3) \mathrm{mm}$ wide near the base, terete, \pm compressible, finely but weakly ribbed, glabrous to scabrous with minute hairs; nodes (2-) 6-9, exserted, glabrous, $30-50 \%$ wider than the adjacent internodes. Leaf sheaths at first tightly enveloping the culm, later becoming free, glabrous, slightly to moderately ribbed, margins glabrous, basal sheath $0.5-1.5 \mathrm{~cm}$ wide, upper sheath (1-) 3-5 $\mathrm{mm}$ wide. Ligule erose to entire, membranous, 2-8 mm long, glabrous; auricles absent. Leaf blade expanded, linear, 1-3 mm wide, (14-) 17-25 (-40) $\mathrm{cm}$ long, often readily deciduous; abaxial surface slightly ribbed, pilose to scabrous; adaxial surface moderately ribbed, pilose to scabrous; margins glabrous to pilose or scabrous. Panicle 15-60 cm long, exserted, \pm contracted, (1-) 2-4 (-5) $\mathrm{cm}$ wide (excluding awns); axis terete, glabrous; branches to $13 \mathrm{~cm}$ long, angled, scabrous; pedicels (1-) 3-5 (-11) $\mathrm{mm}$ long, angled, scabrous. Spikelets $3(-4) \mathrm{mm}$ long (excluding awn), gaping. Glumes equal to subequal, acute, rounded on the back, pale green, scabrous along the nerves; lower glume 3-3.6 (-5) $\mathrm{mm}$ long, lower $90 \%$ 3-nerved; upper glume $3-3.5(-5) \mathrm{mm}$ long, lower $90-95 \% 3$-nerved. Floret cylindrical without a neck, 2.7-3.5 (-4) $\mathrm{mm}$ long (including callus). Lemma straw-coloured, black at maturity, the surface with white hairs $0.2-0.5 \mathrm{~mm}$ long; lobes and coma absent. Callus $0.25 \mathrm{~mm}$ long, weakly bent, hairs $0.25-0.5 \mathrm{~mm}$ long, the same colour as those on the lemma. Awn 33-53 mm long, pale green to straw-coloured, scabrous with hairs $0.05-0.1 \mathrm{~mm}$ long, weakly once or twice bent, $0.1 \mathrm{~mm}$ wide near the base; column (7-) 10-16 (-30) $\mathrm{mm}$ long, 7-12 mm to the first bend; bristle often darker than the column. Palea $30-60 \%$ the length of the lemma, obtuse, the surface smooth to scabrous on the lower half, margins glabrous. Lodicules 2, abaxial, membranous, oblong. Anthers $1.5-2.8 \mathrm{~mm}$ long, penicillate. Caryopsis $2.1-3.5 \mathrm{~mm}$ long; embryo $25-30 \%$ the length, hilum c. $50 \%$ the length.

DiSTRIBUTION: Widespread through eastern Queensland and the central and northern parts of New South Wales.

Selected Specimens: QueEnsland: Mitchell: 'Warren Point', Martensz 94, 22.8.1968 (CANB). Leichhardt: Minerva, N. of Springsure, Blake 6928, 21.7.1934 (BRI); Carnarvon National Park, Trapnell \& Williams, 29.6.1965 (BRI); 3 miles [5 km] E. of 'Glenmoral', Speck 1883, 17.10.1963 (BRI, NSW, CANB); 32 miles [51 km] W. of Theodore, Lazarides 6925, 7.8.1963 (CANB); Isla Gorge, Sharpe \& Hockings, 21.8.1973 (BRI); 'Boxvale', White 9476, 26.10.1933 (BRI); 5.5 miles [9 km] N. of Wandoan, Speck 1968, 26.4.1964 (BRI, NSW, CANB, K). Burnett: Mundubbera, Bloxsome, 1930 (BRI); Gayndah, White, 13.5.1917 (BRI). Warrego: 'Chesterton', Blake I1096, 7.4.1936 (BRI, NSW); $24 \mathrm{~km}$ from Augathella on Tambo road, Simon \& Clarkson, 18.5.1975 (BRI, NSW). Maranoa: Mitchell, Blake 5734, 4.4 .1934 (BRI); $45 \mathrm{~km} \mathrm{S.} \mathrm{of} \mathrm{Roma,} \mathrm{Surat} \mathrm{road,} \mathrm{Blaxell} 1027$ \& Johnson, 29.11.1972 (BRI); between Tara \& St. George, Ebersohn, 3.7.1962 (BRI); Noondoo, nr. Dirranbandi, Blake 10740A, 9.3.1936 (BRI). Darling Downs: c. 14 miles [22 km] NE. of 
Chinchilla, Boyland 672, 9.2.1970 (BRI); Chinchilla, Maiden NSW 115957, 3.1909 (NSW); Jandowae, Moore, 3.1920 (BRI); $16 \mathrm{~km} \mathrm{SW.} \mathrm{of} \mathrm{Dalby,} \mathrm{Gillieatt,} \mathrm{21.9.1964} \mathrm{(BRI);} \mathrm{c.} 12$ miles [19 km] W. of Meandarra, Johnson 753, 23.3.1959 (BRI); nr. Allora, Blake 295, 25.6.1932 (BRI); Hermitage Research Station, Simon \& Henderson, 9.12.1974 (BRI); between Inglewood \& Milmerran, White 9729, 20.1.1934 (BRI); Yelarbon, Blake 10466, 22.2.1936 (BRI); Kurrumbul, Everist 702, 13.12.1934 (BRI); Maryland Creek, 28³8'S, 151 $38^{\prime} \mathrm{E}$, Wilson 4251a, 31.12.1981 (NSW); Wyberba, Blake 4642, 23.1.1933 (BRI). Moreton: nr. Yarraman, Phillips CBG 001278, 6.6.1961 (CBG); Brisbane River, White, 10.1915 (BRI); between One Mile Creek \& Samson Vale, Blake 192, 28.12.1931 (BRI); Brisbane, Blake 167, 27.2.1931 (BRI); Laidley, White 6820, 5.7.1930 (BRI).

New South WALES: North Coast: Lismore, Hewitt NSW 115960, 12.1909 (NSW); Singleton, Boorman NSW 115963, 4.1908 (NSW); Bulga Ranges, Brown NSW 115964, 3.1906 (NSW). Central Coast: Windsor to Kurrajong, Gray 5988, 29.11.1966 (CANB); Penrith, Betche NSW 115971, 1899 (NSW); Flemington, Vickery NSW 115967, 5.1929 (NSW); Kogarah, Cheel NSW 115969, 10.1899 (NSW); Glenfield, Cheel NSW 115972 (NSW). South Coast: Pig I., Shoalhaven River, Rodway NSW 115973, 1.1.1932 (NSW); Bega, Waterson NSW 115975, 12.1912 (NSW). Northern Tablelands: Moona Plains, Crawford NSW 115962, 3.1899 (NSW). North Western Slopes: Wallangra, Boorman NSW 115991, 4.1913 (NSW): Warialda, Hadley NSW 115992, 5.1908 (NSW); Gravesend to Glandon, Carne NSW I15993, 5.1914 (NSW); Inverell, Thomas NSW 115995, 1.1913 (NSW); Woods Reef, Rupp NSW 115996, 6.1913 (NSW); Boggabri, Cambage NSW 115997, 11.1909 (NSW); Baradine, Jensen NSW 115998, 8.1911 (NSW); Manilla, McKie NSW 2524, 11.1938 (NSW); Gunnedah, Cleland NSW 116000, 2.1911 (NSW); Bugaldi, Woodhill NSW 115999, 2.1934 (NSW); between Piallamore \& Dungowan, Goode 74, 11.1954 (NSW); Breeza, Court NSW 116003, 5.1899 (NSW). Central Western Slopes: Trangie, Helms NSW 31946, 11.1892 (NSW); Moonan Flat, Maiden \& Boorman NSW 115961, 5.1902 (NSW, PERTH); Cassilis, Reeve \& Cook 23, 11.3.1972 (CANB); Dunedoo, Nicholson NSW 115978, 6.1931 (NSW); Pages River, Maiden NSW 115979, 8.1899 (NSW); Belltrees via Scone, White NSW 115980, 2.1920 (NSW. BRI); Narromine, Cowman NSW 115981, 8.1946 (NSW); W. of Dubbo, Narromine Road, Henderson NSW 9297, 1.1948 (NSW); Growee Creek, nr. Bylong, Gauba CBG 046359, 8.3.1954 (CBG); Baerami Creek, SW. of Muswellbrook, Story 6739, 10.1959 (NSW, K); Wollar East, Johnson \& Constable NSW 16043, 8.1950 (NSW); Yarrabin Road, Mudgee, Wyndham 3562, 16.3.1978 (NSW); 5 miles [8 km] S. of Cowra, McBarron 9176, 8.1964 (NSW). South Western Slopes: Thurgoona, nr. Albury, McBarron 6082, 2.1953 (NSW). North Western Plains: 15 miles [24 km] W. of Garah, Solling 494, 4.1973 (NSW); 16 miles [25 km] N. of Moree, McBarron 15752, 9.1968 (NSW); Burren Junction, Boorman NSW 115986, 6.1907 (NSW); Coonamble, Breakwell NSW I15988, 10.1912 (NSW); Gular, Brown NSW 115989, 6.1913 (NSW); 33 miles [53 km] W. of Nyngan, Cobar road, Cunningham 901, 5.1969 (NSW); Nyngan, Little NSW 115990,1920 (NSW); 62 miles [99 km] E. of Cobar on Barrier Highway, Moore 3924, 19.11.1966 (CANB).

\section{Stipa vickeryana J. Everett \& S.W.L. Jacobs, Telopea 2(4): 397 (1983).}

Holotype: South Australia: Ifould Lake, Nullarbor Plain Series R502 Barton $512174,30^{\circ} 55^{\prime} \mathrm{S}$, $132^{\circ} 05^{\prime} \mathrm{E}$. Common grass. Forming dense clumps. Heads open, spreading. R.J. Chinnock 2729, 2.x.1975 (AD).

Caespitose annual or perennial to $45 \mathrm{~cm}$ high. Culms (1.5-) $2-2.5 \mathrm{~mm}$ wide near the base, terete to slightly flattened, ribbed, glabrous; nodes $1-2$, glabrous. Leaf sheaths loose around the culms, glabrous except for the shortly pubescent bases of lowermost sheaths; outer margin fringed with long, woolly cilia; inner margin not ciliate. Ligule 3.5-8 (-13) mm long, laciniate, densely ciliate with long woolly hairs especially on those of the lower sheaths. Leaf blades to $18 \mathrm{~cm}$ long, $1.5-4 \mathrm{~mm}$ wide, often folded; abaxial surface unribbed, glabrous except for the very sparsely scabrous long-acute tip; adaxial surface strongly ribbed, the ribs covered with short \pm antrorse hairs. Panicle $9-20 \mathrm{~cm}$ long, slightly spreading, the base enclosed by the sheath. Spikelets scarcely gaping at maturity, widely gaping after floret disarticulation, 14-18 mm long (excluding awn). Glumes unequal, firm at the base, hyaline at the fine acuminate tip, the lower $75 \%$ 3-nerved, scaberulous on the nerves, glabrous between the nerves or minutely pubescent especially at the tip; lower glume $14-18 \mathrm{~mm}$ long, 3-nerved; 
upper glume 9-14 mm long, 5-nerved at the base. Floret fusiform to turbinate, 6-7 mm long (including callus). Lemma deep brown at maturity, smooth except for an antrorsely scabrous neck, glabrous to very sparsely clothed with coppery hairs, denser along the margins; coma sparse, 1-1.5 mm long in two tufts. Callus straight, $2.5-3 \mathrm{~mm}$ long, with a tuft of coppery hairs. Awn relatively slender for its length, c. $0.3 \mathrm{~mm}$ wide near the base, (80-) 90-125 mm long, \pm straight to gently twice bent or sinuate; column $26-32 \mathrm{~mm}$ long, $15-18 \mathrm{~mm}$ to the first bend, densely pubescent with antrorse hairs $0.2-0.3 \mathrm{~mm}$ long; bristle antrorsely scabrous. Palea obtuse, subequal to the lemma, with sparse coppery hairs along the midline. Lodicules 3 , membranous, spathulate; the 2 abaxial c. $1 \mathrm{~mm}$ long, the paleal much smaller. Anthers not observed. Caryopsis not observed.

DiSTRIBUTION: Inland saline areas from eastern Western Australia to central South Australia.

SPECIMENS EXAmined: SOUTH Australia: Nullarbor: W. of Yarle Lakes, Bowen 312, 9.1956 (K); Ifould Lake, 30 55'S, $132^{\circ} 05^{\prime} \mathrm{E}$, Chinnock 2729, 2.10.1975 (AD, NSW), Lothian 4033, 3.6.1967 (AD); Lake Ifould Crossing, Copley 2644, 28.7.1969 (AD).

Western Australia: Coolgardie: Norseman, Andrews, 10.1903 (PERTH).

Differs from $S$. eremophila in having few scattered hairs on the lemma (densely hairy in $S$. eremophila), in its long-hairy orifices (glabrous or sparsely hairy in S. eremophila) and longer (usually less than $1.5 \mathrm{~mm}$ in $S$. eremophila) laciniate ligules. $S$. vickeryana vegetatively resembles $S$. macalpinei but differs in its less hairy, broader and darker-coloured mature lemma. Additionally, on the sheaths, $S$. macalpinei has characteristic broad, curled, glistening-translucent hairs, quite different from the narrow, crinkled, more opaque hairs on those of S. vickeryana.

S. vickeryana differs from $S$. nullanulla in having coarser, usually folded leaves (rolled in $S$. nullanulla), a less open inflorescence and longer lemma and awn.

\section{Stipa wakoolica J. Vickery, S.W.L. Jacobs \& J. Everett, sp. nov.}

$S$. metatori affinis sed glumis flosculisque brevioribus, coma aristaque plerumque breviore, differt.

HolotyPE: New SOUTH WALES: South Western Plains: NE. of Lake Tooim, D.L.W. Henderson 442, 5.11.1947 (NSW 117410; isotypes UTC, K, US, BRI, MEL, AD, PERTH).

Densely caespitose perennial to 1 metre high with conspicuously extravaginal innovations. Culms erect or geniculate at the base, $1.5-3 \mathrm{~mm}$ wide near the base, terete, compressible, slightly ribbed, densely pubescent to hirsute at the base, the upper internodes similar or scaberulous to glabrous except just below the nodes; nodes $2-3$, densely sericeous, exserted, to $40 \%$ wider than adjacent internodes. Leaf sheaths tightly enclosing the culms, ribbed, densely pubescent to hirsute; inner margin similar to adjacent surfaces; outer margin densely longwoolly ciliate. Ligule firm, $0.5-0.8 \mathrm{~mm}$ long, obtuse to truncate, densely ciliate, abaxial surface sericeous; auricles spreading, the inner auricle conspicuously tufted. Leaf blade expanded to inrolled, $1.5-2.5 \mathrm{~mm}$ wide at the base, to $40 \mathrm{~cm}$ long; abaxial surface slightly ribbed, densely pubescent and hirsute; adaxial surface strongly ribbed, densely pubescent and hirsute. Panicle spreading, moderately dense, to $36 \mathrm{~cm}$ long, exserted at length, with distant fascicles of many-flowered branches, $3-5 \mathrm{~cm}$ wide (excluding awns); axis \pm angular, finely scaberulous; branches to $10 \mathrm{~cm}$ long, angular, scabrous; pedicels $2-7 \mathrm{~mm}$ long, 
angular, scabrous. Spikelets 11-15 mm long (excluding awn), gaping early in development. Glumes unequal, firm at the very base, membranous and purpletinged to hyaline at the tip, minutely scabrous on the nerves; lower glume 11-15 mm long, acuminate, the lower $60 \%$ 3-nerved; upper glume 9-11 mm long, broadly acute, the lower 50\% 5-nerved, the next $15 \% 3$-nerved. Floret turbinate, the three main nerves thickened at the apex, 5.5-6.5 mm long (including callus). Lemma deep brown at maturity, \pm smooth, sericeous with dense white hairs yellowing at maturity, the apex finely tuberculate and glabrous near the midrib; coma of erect soft hairs $2-2.5 \mathrm{~mm}$ long; lobes 2 , less than $0.2 \mathrm{~mm}$ long. Callus $1.5-2 \mathrm{~mm}$ long, fine and straight, with hairs similar to those of the lemma. Awn 0.2-0.25 mm wide near the base, 35- $60 \mathrm{~mm}$ long, twice bent; column 15-25 mm long, 7-10 $\mathrm{mm}$ to the first bend, scabrous with hairs less than $0.15 \mathrm{~mm}$ long; bristle scabrous, slightly curved. Palea acute to obtuse, subequal to the lemma (to $0.5 \mathrm{~mm}$ shorter), coriaceous, shiny, with a broad band of dense hairs down the centre, hyaline and glabrous at the margins. Lodicules 2, abaxial, membranous, c. $1 \mathrm{~mm}$ long, oblong. Caryopsis 3-4 mm long; embryo $30 \%$ the length; hilum $60-75 \%$ the length.

DistRIBUTION: Floodplains of the Murray River tributaries of the South Western Plains of New South Wales.

Specimens Examined: New South Wales: South Western Plains: Meran Creek, Henderson 439 , 16.11.1947 (NSW, UTC); N. of Lake Tooim, Henderson 443, 31.10 .1947 (NSW, UTC, K, BRI); Tulla, Henderson 126, 10.1945 (NSW, K).

The specific epithet is derived from the name of the Wakool shire, to which the species appears to be confined.

\section{Acknowledgements}

We wish to thank the many people who were involved in helping us with this study, especially Genevieve Godwin, Anna-Louise Quirico, Susanne Walker, Jeannie Highet, Liz Norris, Nerida Ashby and Robyn Thurtell. We would also like to thank Karen Wilson for preparing the Latin diagnoses and Don McGillivray for his useful comments on nomenclatural aspects.

We also acknowledge the assistance of the Directors of the various herbaria who lent specimens.

This study was largely funded by grants from the Australian Biological Resources Study.

Received 22 Aug. 1984

Accepted 26 Sept. 1985 


\section{Index to Names}

Entries in bold type are of new taxa; entries in roman type are accepted names; entries in italics are of synonyms or misapplied or illegitimate names.

Dichelachne setacea $(\mathrm{R} . \mathrm{Br}$.) Nees $=\mathrm{S}$. setacea 113

Dichelachne stipoides Hook. f. = S. stipoides 116

Stipa acrociliata Reader 25 acrociliata var. minor Reader $=$ platychaeta 93

aphanoneura Hughes = flavescens 59

aphylla (Rodway) Townrow 26

appendiculata $\mathrm{Mez} 13$

aquarii Vickery, Jacobs \& Everett 27

"aquavilla" see aquarii 28

arachnopus Pilger $=$ puberula 95

aristiglumis F. Muell. 28

aristiglumis var. cana Reader $=$ blackii 32

bigeniculata Hughes 30

blackii C.E. Hubbard 32

blakei Vickery, Jacobs \& Everett 34

brachychaeta Godr. see caudata 39

brachystephana S.T. Blake = setacea 114

breviglumis J. Black 35

campylachne Nees 36

caudata Trin. 38

centralis Vickery, Jacob \& Everett 39

clelandii Summerhayes \& Hubbard = blackii 32

commutata Trin. \& Rupr. = pubescens 97

compacta Hughes $=$ flavescens 59

compressa $\mathrm{R}$. Br. 40

compressa var. lachnocolea Benth. = macalpinei 70

congesta Summerhayes \& Hubbard = densiflora 44

crinita Gaudich. 41

curticoma J. Vickery 42

densiflora Hughes 44

dielsii Mez 13

dongicola Vickery, Jacobs \& Everett 46

drummondii Steud. 47

dura $\mathrm{J}$. Black $=$ eremophila 54

echinata Vickery, Jacobs \& Everett 50

effusa Hughes $=$ nodosa 86

elatior (Benth.) Hughes $=$ flavescens

59

elegantissima Labill. 51

eminens Nees $=$ neesiana 81

eremophila Reader 53

eremophila var. dodrantaria $\mathrm{J}$. Black $=$ plumigera 94

eriopus Benth. $=$ tenuifolia 119

exilis J. Vickery 56 falcata Hughes $=$ scabra ssp. falcata 110

falcata var. minor $\mathrm{J}$. Black $=$ nodosa 86

feresetacea Vickery, Jacobs \& Everett 58

flavescens Labill. 59

fusca C.E. Hubbard = eremophila 53

fusiformis Hughes = aristiglumis 29

gibbosa J. Vickery 62

hemipogon Benth. 63

hirsuta Hughes = flavescens 59

horrifolia J. Black $=$ drummondii 47

hyalina Nees 66

incurva Hughes = tenuifolia 119

indeprensa $\mathrm{J}$. Black $=\mathrm{S}$. hemipogon 63

juncifolia Hughes 66

lachnocolea (Benth.) Hughes = macalpinei 70

laeviculmis Nees poss. $=$ flavescens 59

laevis Mez poss. $=$ flavescens 60

lanata Vickery, Jacobs \& Everett 68

leptophylla Hughes = tenuifolia 119

leucotricha Trin. \& Rupr. 69

longearistata Steud. $=$ compressa 40

luehmannii Reader $=$ drummondii 47

macalpinei Reader 70

megapotamia Spreng. ex Trin. 72

metatoris Everett \& Jacobs 73

micrantha Cav. $=$ Dichelachne micrantha 13

micrantha $\mathrm{R} . \mathrm{Br}$. = verticillata 127

micrantha Sieber ex Trin. =

ramosissima 102

mollis $\mathrm{R}$. Br. 74

muelleri Tate 77

multispiculis J. Black 78

mundula J. Black 79

neesiana Trin. \& Rupr. 81

nervosa Vickery $=$ rudis ssp. nervosa 106

nervosa var. neutralis Vickery $=$ rudis

ssp. rudis 104

nitida Summerhayes \& Hubbard 82

nivicola J.H. Willis 85

nobilis Pilger $=$ hemipogon 63

nodosa S.T. Blake 86

nullanulla Everett \& Jacobs 89

nullarborensis Vickery, Jacobs \&

Everett 88

oligostachya Hughes 90

"peronensis" see crinita 42

petraea J. Vickery 91

pilata Jacobs \& Everett 92 
plagiopogon $\mathrm{J}$. Black $=$ mollis 74 platychaeta Hughes 93

plumigera Hughes 94

puberula Steud. 95

pubescens R. Br. 97

pubescens var. aphylla Rodway = aphylla 26

pubescens var. auricoma Reader $=$ eremophila 53

pubescens var. comosa $\mathrm{J}$. Black = blackii 32

pubescens var. effusa Benth. = variabilis 124

pubescens var. maritima $\mathrm{J}$. Black = flavescens 59

pubescens var. semiglabra Reader $=$ pubinodis 99

pubescens var. tenuior Reader 13

pubinodis Trin. \& Rupr. 99

pycnostachya Benth. 100

ramosissima (Trin.) Trin. 101

readeri $\mathrm{F}$. Muell. ex Reader $=$ acrociliata 25

rudis Spreng. 103

rudis ssp. rudis Spreng. 104

rudis ssp. australis Everett \& Jacobs 105

rudis ssp. nervosa (Vickery) Everett \& Jacobs 106

rugulosa $\mathrm{Mez}=$ ramosissima 102

scabra Lindl. 107

scabra var. auriculata J. Black poss. = drummondii 47

or poss. $=$ nitida 82

scabra var. barbata Benth. = flavescens 59

scabra var. elatior Benth. = flavescens 59

scabra ssp. falcata (Hughes) Vickery, Jacobs \& Everett 110

scabra var. occidentalis Benth. = tenuifolia 119

scabra var. pallida Reader $=$ nitida 82

scabra var. pubescens Benth = tenuifolia 119 scabra Lindl. ssp. scabra 108

scabra var. striata Benth. = flavescens 59

scabra var. subtricha Reader poss. = drummondii 47

scelerata Behr ex Black = macalpinei 70

semibarbata R. Br. 111

semibarbata var. campylachne (Nees)

Benth. = campylachne 36

semibarbata var. gracilis $\mathrm{J}$. Black = hemipogon 64

semibarbata var. mollis ( $\mathrm{R}$. Br.) Benth. $=$ mollis 74

setacea R. Br. 113

setacea var. latifolia Benth. = macalpinei 70

setacea var. latiglumis $\mathrm{J}$. Black = setacea 113

stipoides (Hook. f.) Veldkamp 116

striata Link 13

stuposa Hughes 117

tenuifolia Steud. 119

tenuiglumis Hughes $=$ flavescens 59

teretifolia Steud. $=$ stipoides 116

trichophylla Benth. 121

tuckeri F. Muell. 123

variabilis Hughes 124

variabilis Hughes var. elatior (Benth.)

C.A. Gardner $=$ flavescens 59

variabilis var. striata (Benth.) C.A.

Gardner $=$ flavescens 59

variegata Summerhayes \& Hubbard = eremophila 54

velutina Vickery, Jacobs \& Everett 126 verticillata Nees ex Spreng. 127

vickeryana Everett \& Jacobs 128

wakoolica Vickery, Everett \& Jacobs 129

Streptachne verticillata (Nees ex Spreng.)

Trin. \& Rupr. $=$ S. verticillata 127

Urachne ramosissima Trin. $=\mathrm{S}$. ramosissima 101 


\section{$2 \mathrm{BHL}$ Biodiversity Heritage Library}

Vickery, Joyce W., Jacobs, Surrey, and Everett, Joy. 1986. "Taxonomic studies in Stipa (Poaceae) in Australia." Telopea: Journal of plant systematics 3(1), 1-132. https://doi.org/10.7751/telopea19864701.

View This Item Online: https://www.biodiversitylibrary.org/item/266401

DOI: https://doi.org/10.7751/telopea19864701

Permalink: https://www.biodiversitylibrary.org/partpdf/305622

\section{Holding Institution}

The Royal Botanic Gardens and Domain Trust, New South Wales, Australia

\section{Sponsored by}

Atlas of Living Australia

\section{Copyright \& Reuse}

Copyright Status: In copyright. Digitized with the permission of the rights holder.

Rights Holder: The Royal Botanic Gardens and Domain Trust, New South Wales, Australia License: http://creativecommons.org/licenses/by-nc-sa/4.0/

Rights: http://biodiversitylibrary.org/permissions

This document was created from content at the Biodiversity Heritage Library, the world's largest open access digital library for biodiversity literature and archives. Visit BHL at https://www.biodiversitylibrary.org. 